Daniela Monteiro Gabbay

\title{
MEDIAÇÃO \& JUDICIÁRIO: \\ Condições necessárias para a institucionalização dos meios autocompositivos de solução de conflitos
}

Tese de Doutorado

Orientador: Professor Dr. Carlos Alberto de Salles

Faculdade de Direito da Universidade de São Paulo - USP São Paulo

2011 


\section{DANIELA MONTEIRO GABBAY}

\section{MEDIAÇÃO \& JUDICIÁRIO: \\ Condições necessárias para a institucionalização dos meios autocompositivos de solução de conflitos}

Tese apresentada à Faculdade de Direito da USP, na área de concentração de Direito Processual, como requisito para obtenção do título de Doutor.

Orientador: Prof. Dr. Carlos Alberto de Salles.

SÃO PAULO 
Aos meus pais, Albert e Cecy, minha maior fonte de inspiração. 


\section{AGRADECIMENTOS}

Terminar de escrever a tese de doutorado, após três anos de pesquisa, dá uma sensação de alívio e satisfação. Um dos maiores ganhos, contudo, não é de resultado, e sim de percurso. E neste percurso de três anos pessoas muito especiais estiveram presentes em minha vida, a quem eu gostaria de agradecer neste momento.

Primeiramente, à minha família. Aos meus pais, Albert e Cecy, a quem dedico este trabalho, pelo apoio incondicional que me deram e pela base familiar que me fortalece em todos os momentos e em todos os projetos, de vida e de profissão. Ao meu irmão Arthur, grande companheiro e amigo, que esteve ao meu lado nos momentos mais importantes deste trabalho, um agradecimento especialíssimo, que estendo também à sua noiva e futura esposa Bianca, que já faz parte da família. Agradeço também ao meu irmão Marcelo e à minha cunhada Michele, que acompanharam do Rio de Janeiro este percurso e sempre me receberam tão bem na cidade maravilhosa. Sem o apoio da minha família, nenhuma conquista teria o mesmo valor, pois eles são o meu ponto de partida e o de chegada, sempre.

Um agradecimento especial ao meu orientador, professor Carlos Alberto de Salles, que tem acompanhado o meu percurso acadêmico desde o mestrado e a quem devo a oportunidade de iniciar e o estímulo para prosseguir, pois a sua dedicação à academia, à docência e aos alunos é um grande exemplo para mim. Foi ele quem plantou a semente dos meios alternativos de solução de conflitos que gerou o NEMESC (Núcleo de Estudos de Meios de Solução de Conflitos), atividade de extensão na Faculdade de Direito da USP, e que me introduziu, desde 2005, em debates sobre o tema que depois assumi como objeto de investigação no doutorado.

Aos integrantes do NEMESC, agradeço especialmente à Érica Barbosa da Silva, Fernanda Tartuce Silva, Leonardo dos Santos Lusvarghi, Luis Fernando Guerreiro, Marco Antonio Lorencini e Nathalia Mazzonetto, em nome de quem agradeço a todos os demais alunos da graduação e pós-graduação que compõem este grupo que cresce a cada ano.

Para a elaboração desta tese, foi de grande importância o ano que passei na Universidade de Yale, após ser admitida no Fox International Fellowship Program e ter a 
oportunidade de conviver com pessoas de diferentes países e formações. Além das aulas, da estrutura e do ambiente universitário extremamente favoráveis à pesquisa, e da possibilidade de realizar a parte empírica deste trabalho em diferentes Estados norteamericanos, morar um ano fora do país, conhecer novas pessoas e criar uma rotina na pequena e acolhedora cidade de New Haven, em Connecticut, foi uma experiência que me fez voltar diferente, que ampliou perspectivas e mudou a forma de olhar para o tema e para a vida.

Um agradecimento especial a Joseph Carrère Fox e Alison Barbour Fox, responsáveis pelo programa, à Larisa e Amanda, pela organização das atividades e pelo nosso conforto em Yale desde os primeiros dias, e, principalmente, aos meus amigos e demais Foxies, que agradeço em nome de quatro deles: Lizbeth Leyva, Elena Kiryanova, Joe Thomas K. e Jose Moreno Chavez, amigos que fiz em New Haven e que levarei por toda a vida. Também fazem parte deste rol de amigos especiais e a quem gostaria de agradecer: Carolina Cooper, Andres Del Rio, Diego Arguelhes, Mariana Pargendler, Eileen Zelek e Feliciano Guimarães.

A DIREITO GV foi um ambiente de formação muito relevante em minha vida acadêmica, onde ingressei desde 2005 e sempre me defrontei com incentivos e oportunidades de pesquisa e docência.

No âmbito das pesquisas, o ano de 2010 teve importantes acontecimentos, e gostaria de agradecer às duas equipes de pesquisas compostas para enfrentar temas com os quais aprendi bastante. Na pesquisa sobre "Diagnóstico das causas de aumento da litigância e morosidade, mapeamento das demandas repetitivas e propositura de soluções pré-processuais, processuais e gerenciais", agradeço à equipe formada por Arthur Giannattasio, Luci Oliveira, Luciana Ramos, Maria Cecília Asperti, Paulo Eduardo Alves da Silva, Rodrigo Bueno e Rubens Morita. Na pesquisa sobre "O Desenho de Sistemas de Resolução Alternativa de Disputas para Conflitos de Interesse Público”, agradeço à Adolfo Braga Neto, Carlos Salles, Eduardo Paiva, Marco Antonio Lorencini, Natalia Langenegger e Nathalia Mazzonetto. Agradeço especialmente à Luciana Gross Cunha pela experiência de compartilhar a coordenação destas duas pesquisas e pelo convívio com pessoas que, além de colegas de equipe, se tornaram também meus amigos. 
Na pesquisa GV-CBAr sobre Arbitragem e Judiciário, agradeço à equipe inicial formada por Maria Cecília Asperti, Natalia Langenegger, Patrícia Kobayashi. Às pesquisadoras, na época ainda graduandas em direito, devo meus primeiros passos e aprendizado em pesquisa empírica coletiva.

Ainda na Direito GV, agradeço aos meus alunos da Clínica de Mediação e às minhas amigas do Núcleo de Prática Jurídica: Camila Duran, que estava lá quando assumi a Clínica de Mediação e Cássia Nakano Hirai, que a sucedeu, assim como à Fernanda Yamamoto, Flavia Scabin e Bruna Takara, pelo apoio e também pelos intervalos e momentos de descontração que têm um valor especial na reta final de um trabalho acadêmico.

Aos professores Kazuo Watanabe e Antonio Rodrigues de Freitas Jr., que fizeram parte da banca de qualificação desta tese, agradeço pela leitura e sugestões ao trabalho, quando ele ainda estava se moldando e estruturando.

Um agradecimento especial à Cecília Asperti, pela leitura detalhada do trabalho; à Nathalia Mazzonetto, por ter-me recebido em clima tão acolhedor no Natal de 2010, nas vésperas do prazo final do doutorado; ao Paulo Eduardo e ao Adolfo Braga, pelos debates instigantes sobre o tema da tese; ao Rafael Alves, pela leitura e conversas via skype sobre a versão da qualificação; ao professor Esdras Costa, pelo olhar interdisciplinar e pelas conversas que tivemos sobre a relação entre sociologia e direito processual. Foram vários os interlocutores e ambientes de debate e aprendizado, embora a responsabilidade pelos erros incorridos neste trabalho sejam exclusivamente meus.

Por fim, e não menos importante, um agradecimento aos meus amigos, aos que estão longe e aos que estão perto, aos amigos de Belém, aos amigos de São Paulo, aos amigos de toda a vida, que tornaram este desafio de concluir a tese muito mais leve e recompensador. À Catarina Barbieri, Débora Aymoré, Mayte Ximenes Ponte, Flavia Mange, Loiane Verbicaro, Mayanna Amaro, Daniel Silveira, Gabriela Avertano Rocha, Luciana Gross Cunha, Cecília Asperti, Paulo Eduado Silva, Nathalia Mazzonetto, Natalia Langenegger, Kátia Gabbay de Souza, Thomaz Pereira, Rafael Francisco Alves, Susana Henriques da Costa, Mario Shapiro, em nome de quem agradeço a tantos outros que fizeram parte deste percurso acadêmico e que, acima de tudo, fazem parte de minha vida. 


\section{RESUMO}

A questão central deste trabalho refere-se à institucionalização da mediação no âmbito do Judiciário e às condições necessárias para uma boa relação entre a mediação e o processo judicial.

Esta questão foi analisada sob as perspectivas processual e institucional. A primeira recai sobre as bases do processo de mediação, em especial o devido processo legal mínimo, e a sua interação com o processo judicial, diferenciando a justiça do processo e a justiça do resultado. A segunda recai sobre o desenho dos programas de mediação que funcionam junto ao Judiciário e os papéis assumidos pelos diferentes atores que participam destes programas: juízes, mediadores, partes, advogados e funcionários dos Tribunais. Sob esta última perspectiva, foi realizada pesquisa empírica e comparada em programas de mediação que funcionam junto ao Judiciário no Brasil e nos EUA.

Palavras-chave: institucionalização da mediação, devido processo legal mínimo, desenho dos programas de mediação no Judiciário, pesquisa empírica. 


\begin{abstract}
The main issue of this work is the institutionalization of mediation within the Courthouse and the pre-conditions for having a good relationship between mediation and the Judiciary.

This issue is analyzed from both procedural and institutional points of view. The procedural perspective falls on the mediation due process (minimal but meaningful due process standards) and on the differences between the procedural and substantial justices. The institutional perspective falls on the design of the Court-Connected Mediation Programs and on the roles of the players who participated in these programs: judges, mediators, plaintiff and defendant, attorneys, and Court workers. An empirical research was also done about the Court-Connected Mediation Programs in Brazil and in the United States.
\end{abstract}

Keywords: institutionalization of mediation, minimal due process, Court-connected mediation programs design, empirical research. 


\section{SUMÁRIO}

1 INTRODUÇÃO ............................................................................................................... 10

2 PROCESSO JUDICIAL E PROCESSO DE MEDIAÇÃO ….................................... 20

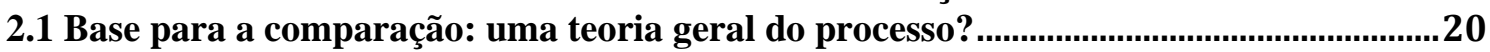

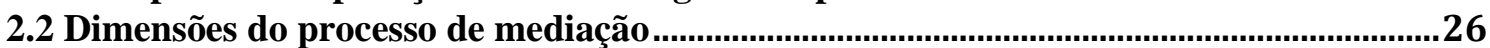

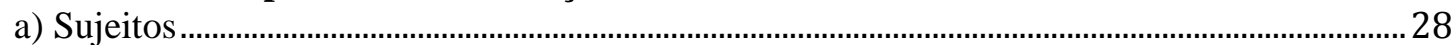

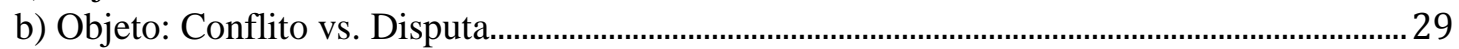

c) Processo: o devido processo legal mínimo na mediação......................................................................

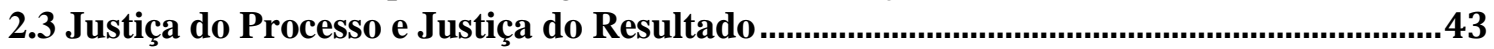

2.4 Publicização da mediação ou privatização do processo judicial? .......................................47

2.5 Distinções entre os meios autocompositivos: mediação, conciliação e negociação...........48

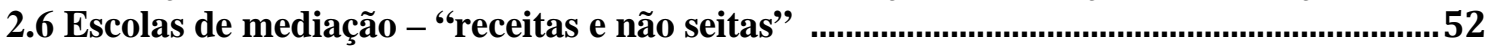

a) Negociação assistida baseada em princípios (problem-solving) ...............................................52

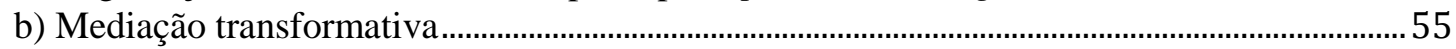

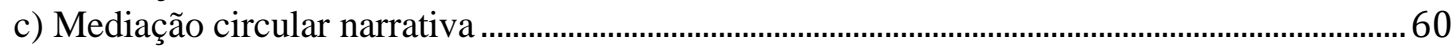

3 INSTITUCIONALIZAÇÃO DA MEDIAÇÃO NO JUDICIÁRIO............................ 62

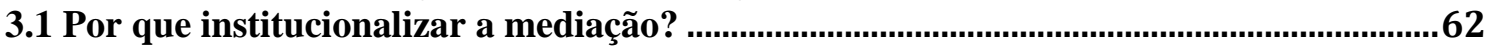

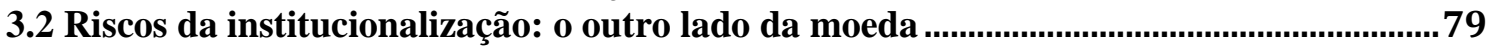

3.3 A institucionalização da conciliação nos Juizados Especiais Cíveis .....................................86

3.4 Meios autocompositivos: entre o comunitário e o institucional ............................................89

3.5 O juiz de paz ............................................................................................................ 98

3.6 Pesquisa empírica nos Programas de Mediação e Conciliação ……............................... 107

4 MEDIAÇÃO NO JUDICIÁRIO NORTE-AMERICANO....................................114

4.1 Medidas voltadas à institucionalização da mediação........................................................ 114

a) Sistema Multiportas de solução de conflitos: o advento dos Court-connected programs nos

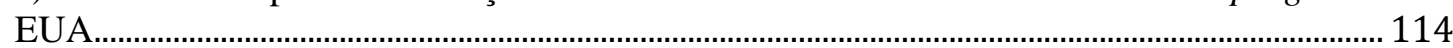

b) Regulamentação dos meios alternativos de solução de conflitos .......................................... 120

c) Mediação e gerenciamento do processo ............................................................................... 124

d) O papel dos magistrate judges nas Cortes Federais e a burocratização do Judiciário........ 131

4.2 PESQUISA EMPÍRICA DOS PROGRAMAS DE MEDIAÇÃO...................................137

a) Justificativa para a escolha dos programas de mediação............................................................137

b) Quadros comparativos dos programas ...................................................................................... 143

5 MEDIAÇÃO NO JUDICIÁRIO BRASILEIRO ....................................................158

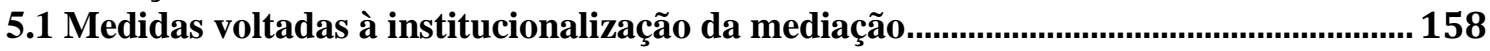

a) Mediação e gerenciamento do processo ................................................................................... 159

b) Regulamentação legislativa e judiciária sobre a Mediação e Conciliação ............................ 163

c) Políticas Judiciárias nacionais sobre a mediação e conciliação .............................................. 170

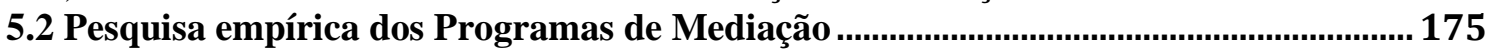

a) Justificativa para a escolha dos programas de mediação......................................................... 175

b) Quadros comparativos dos programas ……………………………………………................ 178

6 INSTITUCIONALIZAÇÃO DA MEDIAÇÃO: DESAFIOS E LIMITES...............204

6.1 Maior atenção aos filtros e à triagem dos conflitos - Screening process......................... 205

a) Como vem acontecendo? ........................................................................................................ 205

b) Como poderia acontecer? .................................................................................................... 208

6.2 Cultura jurídica: sujeitos ativos e passivos das mudanças................................................ 215

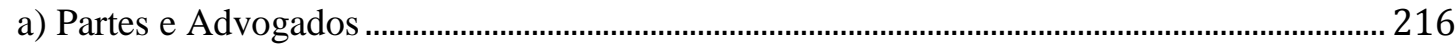

b) Mediadores e Conciliadores ........................................................................................................ 221

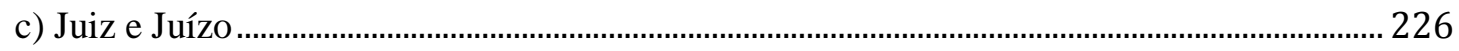

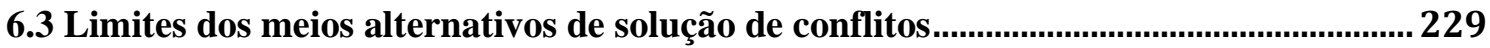




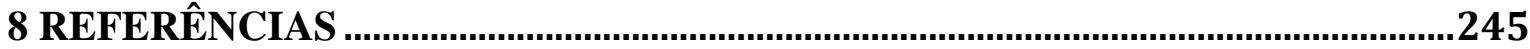

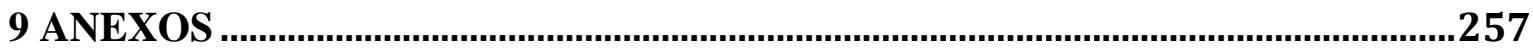
ANEXO A. Questionário de entrevista aplicado aos Diretores dos Programas de Mediação em Ohio, Flórida, Maine e Connecticut.

ANEXO B. Questionário de entrevista aplicado aos Coordenadores dos Programas de Mediação e Conciliação em São Paulo, Distrito Federal e Rio de Janeiro............................ 261 ANEXO C. Resolução no 125 do CNJ, de 29/11/2010 e Código de Ética de Conciliadores e

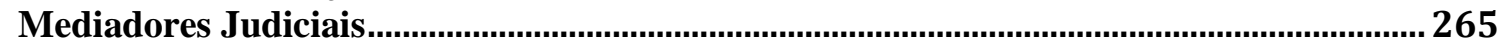




\section{INTRODUÇÃO}

O objeto deste trabalho é o estudo da relação entre a mediação e o processo judicial. Mais do que o estudo aprofundado de cada um isoladamente, são analisadas as principais questões que decorrem do aspecto relacional entre estes dois mecanismos de solução de conflitos.

Esta relação entre a mediação e o processo judicial é estudada no Judiciário, ou seja, no ambiente institucional das Cortes. Não se trata apenas do local físico em que ocorre a mediação, mas de sua institucionalização e realização sob a sombra do Judiciário, quando este direciona a solução do conflito para a mediação, quer antes do processo judicial, quer depois de já instaurado.

A institucionalização da mediação no âmbito judicial depende de sua implementação, regulação e suporte conferidos pelo Judiciário. Isso implica em sua instituição formal por alguma norma (portaria, provimento, resolução, decreto ou lei), com regras acerca de seu procedimento e funcionamento, destinação orçamentária, capacitação de recursos humanos e provimento de cargos para os programas de mediação, fazendo com que a sua continuidade não dependa apenas da iniciativa individual de alguns atores, mas sim da resposta da instituição na qual estão sendo albergados, no caso, do Judiciário.

Esta institucionalização pode ser observada também no âmbito do Executivo, através de iniciativas do Ministério da Justiça ou de Secretarias de Justiça, pode dar-se com a participação de outros atores do sistema de justiça, como o Ministério Público e a Defensoria Pública, ou ainda no âmbito privado, através da atuação das Câmaras de Mediação e Arbitragem. Este trabalho, no entanto, tem por foco a institucionalização da mediação no Judiciário, que vem se destacando, há quase uma década no Brasil e três décadas nos EUA, sobretudo com a criação de programas e setores de mediação/conciliação nos Tribunais, e possibilitando o acesso a estes mecanismos consensuais de solução de conflitos a partir do próprio Judiciário.

Nesse cenário, destaca-se no Brasil a recente "Política Judiciária Nacional de Tratamento adequado dos Conflitos de Interesses no âmbito do Judiciário", instituída em 
novembro de 2010 pela resolução $\mathrm{n}^{\circ} 125$ do Conselho Nacional de Justiça (CNJ), como forma de assegurar a conciliação e mediação de conflitos em todo o país, determinando que os órgãos judiciários ofereçam, além da solução adjudicada mediante sentenças dos juízes, mecanismos de resolução consensual de controvérsias entre as partes, bem como a prestação de atendimento e orientação aos cidadãos, incentivando a autocomposição de litígios e a pacificação social por meio da conciliação e mediação ${ }^{1}$.

O ponto de partida rumo à institucionalização da mediação já foi dado pelo Judiciário, que assume o papel de protagonista no apoio à mediação como medida de solução de conflitos e de administração da Justiça. Os caminhos, todavia, não estão definitivamente traçados, sendo o objetivo deste trabalho, por meio do estudo empírico de experiências e práticas já realizadas no Brasil e nos EUA, contribuir para os passos ainda por serem dados.

O problema central enfrentado refere-se à seguinte pergunta: quais são as condições que devem ser buscadas para uma boa interação entre a mediação e o processo judicial, ou seja, para a institucionalização da mediação no âmbito do Judiciário?

Para responder a esta pergunta, são formuladas as seguintes hipóteses:

1. Uma boa interação entre a mediação e o processo judicial depende de que a mediação não seja vista apenas como um contraponto ao processo judicial ou uma alternativa à morosidade e ao sistema adversarial, mas sim considerada a partir de suas bases constitutivas, de predicados e valores que lhe são próprios. A identificação das bases constitutivas do processo de mediação (devido processo legal mínimo) revela-se ainda mais relevante quanto mais próxima a mediação está do ambiente institucional do Judiciário.

2. Além da identidade processual, a mediação precisa ter resguardada sua identidade funcional junto ao Judiciário: o desenho institucional e os objetivos dos programas, as escolhas realizadas (mediação obrigatória ou voluntária, pré-processual ou

\footnotetext{
${ }^{1}$ A resolução no 125, de 29/11/2010, está disponível no site www.cnj.jus.br Acesso em 20/12/2010. Maiores detalhes sobre esta resolução podem ser conferidos no capítulo 5 deste trabalho, que trata de políticas judiciárias nacionais sobre mediação e conciliação.
} 
processual), a triagem dos conflitos, o procedimento adotado e os papéis assumidos pelos atores envolvidos precisam ser claramente definidos, pois influem na boa relação entre a mediação e o processo judicial.

3. A institucionalização da mediação no Judiciário é positiva quando vista como uma das formas possíveis de incentivo e suporte à mediação, sem, porém, excluir outras portas de acesso à mediação, não atreladas a mecanismos judiciais.

Uma das peculiaridades da mediação está em sua forma não adversarial/contenciosa de processar o conflito, na qual as partes assumem a responsabilidade conjunta pela construção da solução, figurando o terceiro (mediador) apenas como facilitador do diálogo entre elas.

Para investigar os ganhos qualitativos gerados por esse processo, é preciso, antes de tudo, analisar o próprio processo de mediação, e isso não apenas através de definição pela negação (não é adversarial, não é formal, não é judicial), mas mediante uma abordagem direcionada a destacar as bases constitutivas da mediação, incluindo a averiguação da necessidade, em determinado grau, de um devido processo legal mínimo na mediação.

O foco nas dimensões estruturantes da relação (sujeitos, objeto e procedimento) é importante para que a mediação não seja vista como simples coadjuvante ao processo judicial, apenas como uma fase incidental de seu procedimento (destinada à obtenção do consenso entre as partes), mas seja analisada a partir de si mesma e de seus próprios valores.

A esse propósito, cabe mencionar a posição de Marc Galanter, destacando a importância de se resistir à generalizada e equivocada caracterização dos meios alternativos de solução de conflitos como meros informalismos. Em suas palavras, "os mecanismos alternativos de solução de controvérsias não são informalismos, mas sim formalismos de forma breve (short form formalism), não são desprofissionalização, mas sim uma mudança na atuação dos profissionais"2.

\footnotetext{
${ }^{2}$ GALANTER, Marc. Compared to what? Assessing the quality of Dispute Processing. Denver University Law Review, v. 66, 1989, pp. xi-xiv. Galanter considera neste artigo a existência de critérios quantitativos e qualitativos para se avaliar os meios alternativos de solução de conflitos, a partir do que denomina de
} 
Sob essa abordagem, objetiva-se, no primeiro capítulo deste trabalho, investigar o processo de mediação e as suas interfaces com o processo judicial, tomando por base a teoria geral deste último.

A esse respeito, a ideia de sombras revela-se muito útil à comparação entre o processo judicial e o processo de mediação. Vale-se desse conceito para averiguar os efeitos da mediação quando realizada sob a sombra do processo judicial e deste último sob a sombra da mediação, segundo a expressão em inglês, the shadow of the Courts and the shadow of Mediation. A partir deste jogo de sombras, polarizam-se tensões entre rigidez e flexibilização das formas, entre a "privatização" do processo judicial e a "publicização" da mediação.

É importante reconhecer o poder estatal existente sob essas sombras, como ressaltam C. Harrington (Shadow Justice is a form of State Power) ${ }^{3}$ e David Trubek, que, tomando por base a sociologia do processo, alertam para a autoridade camuflada que pode emergir do discurso dos interesses e do âmbito da microfísica de poder da mediação ${ }^{4}$.

O devido processo legal vislumbrado na mediação, nesse sentido, também pode ter significado enquanto uma forma de contenção de poder.

Há três caminhos tradicionais pelos quais um conflito ou disputa pode ser direcionado à solução por mecanismos alternativos de solução de conflitos: i. por livre vontade das partes; ii. por determinação de alguma norma; e iii. por determinação judicial ${ }^{5}$.

Quando a porta de ingresso a estes caminhos se situa no Judiciário, estando a mediação e a conciliação no ambiente judicial, há uma tendência de considerá-las servis e

argumentos de massa de produção (aptidão de um mecanismo de produzir mais com menos recursos), que admite quantificação do custo e tempo, e argumentos qualitativos, que avaliam o meio de solução de conflito a partir do grau de satisfação das partes, do restabelecimento de relações continuadas, do nível de porosidade a normas sociais, do cumprimento espontâneo das soluções alcançadas, e assim por diante. Ressalta Galanter que a análise e aferição dos ganhos de qualidade têm recebido muito menos atenção do que os mais facilmente mensuráveis ganhos de produtividade.

${ }^{3}$ Vide HARRINGTON, Christine B. Shadow justice: the ideology and institutionalization of alternatives to Court. CT: Greenwood Press, 1985.

4 TRUBEK, David M. The handmaiden's revenge: on reading and using the newer sociology of civil procedure, Law and Contemporary Problems, v. 51, 1988

${ }^{5}$ Vide REUBEN, Richard. Constitutional Gravity: a Unitary Theory of Alternative Dispute Resolution and Public Civil Justice, UCLA L. Rev., vol. 47, p. 971. 
instrumentais ao Judiciário e às suas demandas, como uma forma de redução da litigância e da morosidade judicial. Quanto mais distantes do Judiciário (no ambiente comunitário, por exemplo), menor é o risco de serem instrumentais ou de estarem à sombra do processo judicial, sendo menor a preocupação quanto à identidade destas formas consensuais de solução de conflitos ${ }^{6}$.

$\mathrm{Na}$ pesquisa e análise das escolhas que podem ser adotadas por meio da institucionalização da mediação no âmbito do Judiciário, foram considerados os papéis assumidos pelos vários atores envolvidos - juízes, mediadores, partes, advogados e servidores dos Tribunais - e o desenho institucional dos programas envolvendo meios de solução de conflitos alternativos ao Judiciário.

A pesquisa empírica e comparada, realizada entre programas de mediação nos Judiciários brasileiro e norte-americano, buscou aferir em ambos os países as opções adotadas para a institucionalização da mediação. Trata-se de uma pesquisa de diagnóstico, que pautou suas escolhas na diversidade de elementos comparativos dos programas diferentes níveis de regulação, centralização, modelos, volume de casos, dentre outros.

Não se objetivou a indicação de um melhor programa de mediação, nem a mera transposição de experiências entre países, pois não há um modelo padrão a ser seguido e o desenho de cada programa depende do contexto em que está inserido (one size does not fit all). O objetivo desta pesquisa foi comparar para melhor conhecer, contrastar experiências nacionais e estrangeiras para que sobressaia a identidade de cada programa e sistema, produzindo-se dados empíricos a partir da diversidade entre eles.

\footnotetext{
${ }^{6}$ Sobre as mudanças pelas quais passa a mediação quando inserida no Judiciário, Nancy Welsh considera que there is ample evidence that as mediation has entered the courthouse and begun resolving bigger, nonfamily civil cases, the process has diverged from this earlier model. Court-connected mediation now often bears an uncanny resemblance to the judicially-hosted settlement conference. Cf. WELSH, Nancy. Making deals in Court-Connected Mediation: What's Justice got to do with? Wash. U.L.Q, vol. 79, p. 796. Segundo Juliana Demarchi, a perda de identidade da mediação é um efeito colateral a ser evitado, pois acarretaria, consequentemente, a perda das vantagens presentes nesse método de solução de conflitos, como a possibilidade de preservação e aperfeiçoamento dos relacionamentos existentes entre os participantes e o exercício da autodeterminação e responsabilidade pelas próprias partes. Assim, os meios alternativos precisam ser analisados a partir de uma perspectiva mais ampla, não só pelas vantagens e benefícios que podem agregar ao processo judicial, mas também pelas vantagens que lhe são inerentes, intrínsecas, de modo que sejam considerados técnicas voltadas à obtenção da pacificação complementares ao processo perante o Poder Judiciário, e não meramente alternativas. Cf. DEMARCHI, Juliana. Mediação: proposta de implementação no processo civil brasileiro. Tese (Doutorado em Direito Processual) - Faculdade de Direito da Universidade de São Paulo (FDUSP), São Paulo, 2007, pp. 34/214.
} 
No total, foram pesquisados e analisados dez programas de mediação e conciliação, nos EUA e no Brasil, a partir de quatro eixos: i. características gerais dos programas/setores de mediação e conciliação; ii. a triagem/filtragem dos conflitos (screening process); iii. papéis dos atores envolvidos: partes, advogados, juízes, mediadores, coordenador do programa de mediação/conciliação; iv. dinâmica da mediação e conciliação (procedimento e peculiaridades).

No Brasil, onde os níveis de litigância mostram-se elevados, a maior parte dos processos judiciais vai a julgamento ${ }^{7}$, diferentemente do que ocorre nos EUA, onde a maior parte dos processos termina em acordo e menos de 5\% dos processos vai a julgamento ${ }^{8}$. Essa constatação revela uma inversão quanto ao que venha a ser regra e ao que venha a ser alternativa, pois o que se percebe é que o julgamento pela Corte nos EUA tornou-se alternativa, sendo o acordo a regra geral. Todavia, como se verá nos próximos capítulos, por trás desta estatística não está apenas a expansão dos meios alternativos de solução de conflitos. Há outras variáveis e circunstâncias a se considerar e, além do aspecto quantitativo relacionado ao número de acordos, é importante também levar em conta o aspecto qualitativo relacionado ao conteúdo, forma de obtenção e nível de cumprimento dos acordos.

Os custos de uma demanda judicial nos EUA, com Júri para demandas cíveis (o que gera maior grau de incerteza quanto ao resultado), a extensa e complexa fase de produção de provas (discovery) realizada por conta dos advogados, demandando horas e elevados honorários advocatícios, as taxas judiciais, dentre outros fatores, já eram

\footnotetext{
7 O nível de litigiosidade é medido pela proporção entre os casos novos que entram no Judiciário a cada cem mil habitantes, segundo o relatório Justiça em Números do Conselho Nacional de Justiça. Na categoria litigiosidade, calculam-se: os casos novos, a carga de trabalho, a taxa de congestionamento, a taxa de recorribilidade externa, interna e a taxa de reforma da decisão. Os números que atestam o aumento da litigiosidade nas Justiças Estadual e Federal, em 1a e 2a instâncias, estão no relatório Justiça em Números, 2009, disponível em www.cnj.jus.br. Acesso em 20/12/2010. Sobre a cultura da sentença que ainda predomina no Brasil, vide WATANABE, Kazuo. Cultura da sentença e cultura da pacificação. In: YARSHELL, ZANOIDE (Coord). Estudos em homenagem à professora Ada Pellegrini Grinover. DPJ, 2005. pp. 684-690.

${ }^{8}$ In more than 95 percent of American civil lawsuits there is no trial. Vide HEISE, Michael. Justice Delayed? An empirical analysis of civil case disposition time. Case Western Reserve L. Rev., vol. 51, 2000, p. 813. Sobre o baixo número de julgamentos, na Justiça Estadual e Federal nos EUA, vide GALANTER, Marc. A world without trials? Journal of Dispute Resolution, 2006, p. 7-10.
} 
suficientes para impulsionar uma cultura pró-acordo antes mesmo de virem à tona os incentivos aos ADRs (Alternative Dispute Resolution) ${ }^{9}$.

Somem-se a esses fatores de incentivo à cultura pró-acordo as mudanças implementadas nas regras federais de processo civil em prol do gerenciamento da demanda (case management), com um espaço relevante dado à audiência preliminar (pretrial conference), onde o juiz analisa detidamente a admissibilidade da demanda, com possibilidade de sua extinção ou julgamento antecipado (triagens semelhantes às realizadas pelas condições da ação e julgamento antecipado da lide no Brasil), bem como de direcionamento do caso aos meios alternativos de solução de conflitos.

O estudo desses incentivos e de diferentes desenhos institucionais e procedimentais adotados pelos programas de mediação nos EUA pode ser útil para se pensar as escolhas feitas no Brasil ${ }^{10}$, quer a título de desenho a ser adotado, quer a título de políticas judiciárias sobre a implementação e regulação da mediação, levando em consideração o que já vem sendo realizado por alguns Tribunais de Justiça no Brasil.

Os critérios de escolha dos programas e dos Tribunais para a pesquisa empírica, as justificativas metodológicas e os principais resultados comparativos encontrados estão expostos nos capítulos 3, 4 e 5 deste trabalho.

Algumas ressalvas terminológicas são importantes. A primeira relacionada ao termo meios alternativos de solução de conflitos, utilizado no sentido de serem alternativos ao Judiciário, extrajudiciais, traduzindo a expressão Alternative Dispute Resolution (ADR). Muito embora esta denominação seja objeto de crítica ${ }^{11}$, por ter o Judiciário como o centro

\footnotetext{
${ }^{9}$ Mesmo sendo essa pré-existente cultura do acordo um campo fértil para o desenvolvimento da mediação, Bobbi MacAdoo e Nancy Welsh destacam que é difícil dizer se o aumento de acordos não tenderia a acontecer ainda que sem os incentivos à mediação (cases settle anyway), o que estes autores buscaram investigar através da realização de entrevistas a juízes. Cf. WELSH, Nancy A; MCADOO, Bobbi. Look before you leap and keep on looking: lessons from the institutionalization of Court-connected mediation. Nevada Law Journal, vol. 5, 2004-2005, pp. 416-417/ 421.

${ }^{10}$ Muito embora os sistemas de civil law e common law tenham por trás diferentes modelos, linguagens e culturas, há também convergências e pontos comuns entre eles. Cf. CAPPELLETI, Mauro. O processo civil no direito comparado. Tradução Hiltomar Martins Oliveira. Belo Horizonte: Cultura Jurídica - Ed. Líder, 2001, pp. 11, 15. Vide ainda ALEXANDER, Nadja. Mediation in practice: common law and civil law perspectives compared. International Trade and Business Law, vol. 6, 2001, pp. 1-18.

${ }_{11}$ Ao invés de meios alternativos de solução de conflitos, melhor seria que a expressão fosse meios apropriados/adequados de solução de conflitos (Appropriate Dispute Resolution - ADR). Nesse sentido, vide Carrie Menkel-Meadow, Introduction: What Will We Do When Adjudication Ends? A Brief Intellectual
} 
gravitacional, em relação ao qual se dá a alternatividade, ela é adotada neste trabalho em face de seu uso corrente, ressalvada esta crítica com a qual se está de acordo.

Os termos mediação e conciliação são tidos em vários momentos deste trabalho como equivalentes. Isso não quer dizer que não haja importantes diferenças entre estas formas de solução de conflitos, que são reconhecidas e tratadas no item 2.5 do segundo capítulo. Porém, para fins de análise da institucionalização de formas autocompositivas de solução de conflitos no Judiciário e da pesquisa comparada, esta equiparação é possível, considerando-se inclusive que muitos programas denominados nos EUA de mediação seriam tidos no Brasil como programas de conciliação.

Adotou-se a classificação que distingue os meios de solução de conflitos em autocompositivos e heterocompositivos, dependendo se a solução é fixada de acordo com a autonomia de vontade das partes (autocomposição que pode ser direta ou assistida) ou imposta por terceiro (um juiz ou árbitro, por exemplo). O objeto deste trabalho recai sobre a autocomposição assistida por terceiro - mediação e conciliação - e sua comparação com o processo judicial. Muito embora, como qualquer classificação polarizada, implique em reducionismos conceituais incapazes de dar conta de toda a realidade (como das variadas hipóteses de processos mistos de solução de conflitos), esta classificação é útil por revelar o predomínio da decisão das partes (autonomia da vontade) ou de terceiro (imperatividade de decisão) na solução do conflito ${ }^{12}$, o que repercute na forma de seu processamento ${ }^{13}$.

History of ADR, UCLA L. Rev., vol. 44, 1997, pp. 1613-1625 e BINGHAM, Lisa B. Why suppose? Let's find out: a public policy research program on dispute resolution, 2002, J. Disp. Resol, pp. 101. Carlos Alberto Carmona também faz uma critica à terminologia tradicional, que se reporta a meios alternativos e não a meios adequados de solução de litígios. Segundo o autor, é razoável pensar que as controvérsias tendam a ser resolvidas, num primeiro momento, diretamente pelas partes interessadas (negociação, mediação e conciliação); em caso de fracasso deste diálogo (método autocompositivo), recorrerão os conflitantes às fórmulas heterocompositivas (processo estatal, processo arbitral). Sob este enfoque, os métodos verdadeiramente alternativos de solução de controvérsias seriam os heterocompositivos, não os autocompositivos. Cf. CARMONA, Carlos Alberto. Arbitragem e Processo: um comentário à Lei 9307/96. $3^{\mathrm{a}}$ edição. São Paulo: Atlas, 2009, pp. 32-33.

12 Carlos Alberto Salles, por outro lado, considera que a classificação entre meios autocompositivos e heterocompositivos tem o inconveniente de ser focada na atividade das partes em relação à solução da controvérsia, sem destacar o papel de terceiros, e por isso prefere a classificação entre meios consensuais, adjudicatórios e mistos. De acordo com este autor, para pensar mecanismos institucionalizados, públicos ou privados, de resolução de disputas, o foco não deve estar nas partes, mas nos vários agentes - terceiros encarregados de propiciar o resultado esperado, levando-se em conta as várias maneiras pelas quais é possível alcançá-lo. O diferencial, portanto, deve estar na maneira como esses terceiros atuam em relação às partes e a seus direitos com a finalidade de eliminação da controvérsia pendente, sem subavaliar a sua atuação. Cf. SALLES, Carlos Alberto de. A arbitragem na solução de controvérsias contratuais da Administração Pública. Tese apresentada à Faculdade de Direito da Universidade de São Paulo como requisito para obtenção do título de Livre-Docente junto ao Departamento de Direito Processual, São Paulo, 
O trabalho está dividido em nove capítulos.

Após esta introdução, no capítulo 2 são analisados e comparados os processos judicial e de mediação. O foco está nas dimensões subjetiva, objetiva e procedimental de ambos, considerados como métodos de trabalho, tendo ainda em vista a diferença entre a justiça do processo e a justiça do resultado, bem como a constatação da necessidade de um devido processo legal mínimo na mediação.

Neste capítulo são analisadas as diferenças entre as Escolas de Mediação, levando em conta aquilo no que influenciam o processo de mediação, o papel dos sujeitos e a delimitação do objeto.

O capítulo 3 trata da institucionalização da mediação no Judiciário, partindo da pergunta “Por que institucionalizar a mediação?". São examinados os benefícios e também os riscos que advém desta institucionalização.

Este capítulo traz, ainda, dados e percepções sobre a conciliação nos Juizados Especiais Cíveis e aborda o papel do juiz de paz, como um elo entre o comunitário e o institucional. As linhas gerais da pesquisa empírica sobre os programas de mediação e conciliação são também apresentadas, muito embora os dados e resultados concretos desta pesquisa sejam tratados nos capítulos 4 e 5 seguintes.

No capítulo 4 é analisada a institucionalização da Mediação no Judiciário NorteAmericano, com foco no sistema multiportas de solução de conflitos, os chamados CourtConnected Programs. São estudadas as medidas implementadas para a regulação e

2010, pp. 246-247. Adotando uma taxonomia dos meios de solução de disputas de acordo com o número de partes, Marc Galanter, por sua vez, adota a seguinte divisão: três partes (adjudicação, arbitragem, mediação, fact finding, decisões administrativas, decisões políticas, terapias); formas intermediárias (estaria entre três e duas partes, havendo a figura de um terceiro que assume posição peculiar, como a do ombudsman), duas partes (negociação e bargaining), uma parte (resignação, ato de evitar ou finalizar os conflitos, auto-ajuda), nenhuma parte (falha na apreensão do remédio, violação e demanda). Cf. GALANTER, Marc. Adjudication, Litigation, and related phenomena. In: LIPSON, Leon e WHEELER, Stanton. Law and the social sciences. New York: Russel Sage Foundation, 1986, p. 160.

${ }^{13}$ Isso porque se um terceiro (no caso, o juiz) irá decidir o conflito e impor uma decisão vinculante às partes, o devido processo legal é menos flexível do que na hipótese de as próprias partes decidirem como o conflito será resolvido entre elas. No primeiro caso, o contraditório entre as partes, na apresentação de argumentos e provas, a imparcialidade do terceiro, que deve motivar sua decisão e decidir conforme a lei, prevalecem em relação ao que ocorre na mediação, onde a voluntariedade das partes ocupa maior espaço, muito embora, como será demonstrado a seguir, haja um devido processo legal mínimo a ser resguardado também na mediação. 
incentivo aos meios alternativos de solução de conflitos, e também apresentado o quadro comparativo resultante da pesquisa empírica realizada em programas de mediação anexos aos Tribunais de quatro Estados norte-americanos: Ohio, Maine, Flórida e Connecticut.

O capítulo 5 trata da Mediação no Judiciário Brasileiro, com a apresentação das medidas judiciais e normativas de incentivo à mediação, além do quadro comparativo resultante da pesquisa empírica realizada em programas de mediação e conciliação que funcionam junto ao Judiciário nos Estados de São Paulo, Rio de Janeiro e Distrito Federal.

O capítulo 6 encerra o trabalho com alguns desafios e limites que existem em relação aos meios autocompositivos e à sua institucionalização no Judiciário. Dentre os desafios estão a existência de filtros e a triagem dos conflitos que são encaminhados à mediação, analisando-se quais são os critérios a serem adotados, quem os define, quando e onde devem ser aplicados.

Esse capítulo trata também dos desafios relacionados ao comportamento e mentalidade daqueles que participam do processo de mediação: as partes, os advogados, os mediadores, o juiz e o juízo (cartório). Isso porque nenhuma mudança legislativa e institucional em favor da mediação será possível se não estiver acompanhada de mudanças culturais, de comportamento e de mentalidade.

Por fim, são analisados os limites e críticas aos meios de solução de conflitos alternativos ao Judiciário, considerando-se as críticas externas (institucionais) e internas (procedimentais) à mediação e ao lugar que ela ocupa na administração da Justiça.

O capítulo 7 traz as conclusões centrais do trabalho; o capítulo 8, as referências; e o capítulo 9, os anexos. 


\section{PROCESSO JUDICIAL E PROCESSO DE MEDIAÇÃO}

\subsection{Base para a comparação: uma teoria geral do processo?}

As hipóteses deste trabalho partem da premissa de que há uma relação entre o processo judicial e o de mediação, e de que a identidade processual e funcional da mediação asseguram que esta relação ocorra de forma equilibrada, tendo por base um círculo virtuoso existente entre o Judiciário e as formas alternativas de solução de $\operatorname{conflitos}^{14}$.

O art. 125, IV do Código de Processo Civil (CPC) determina que compete ao Juiz, a qualquer tempo, tentar conciliar as partes, havendo também um momento nos procedimentos sumário e ordinário destinado à audiência de conciliação. Nestes casos, o juiz assume o papel de conciliador. Há, também, a iniciativa do Judiciário em criar setores e centros de Conciliação e Mediação, que funcionam em $1^{\mathrm{a}}$ e $2^{\mathrm{a}}$ instância, conforme se verá nos capítulos seguintes, onde o papel de conciliador ou mediador não é assumido pelo juiz.

A mediação pode se dar antes (pré-processual) ou depois (processual ou incidental) de instaurado o processo judicial, podendo também se realizar sem nenhuma conexão com o processo (extrajudicial), no ambiente comunitário, por exemplo. Em qualquer caso há a possibilidade de uso da coerção estatal caso seja necessário buscar a efetividade e o cumprimento do consenso adotado pelas partes (título executivo extrajudicial ou, uma vez homologado pelo juiz, título executivo judicial, de acordo com o art. 475-N, III e V do CPC).

\footnotetext{
${ }^{14}$ Partindo desta premissa de cooperação entre o Judiciário e os meios alternativos, especialmente a arbitragem, e considerando ser importante o apoio institucional conferido pelo Judiciário a estes meios de solução de conflitos, vide pesquisa empírico-jurisprudencial sobre Arbitragem e Judiciário em GABBAY, Daniela Monteiro; ALVES, Rafael Francisco; LEMES, Selma Ferreira (Coord.). Projeto de pesquisa: Arbitragem e Poder Judiciário. Parceria Institucional Acadêmico-Científica da Escola de Direito de São Paulo da Fundação Getulio Vargas (DIREITO GV) e do Comitê Brasileiro de Arbitragem (CBAR). Revista Brasileira de Arbitragem, vol. 19, 2008, pp. 7-23. Marc Galanter, a partir do que denomina Adjudication Matrix, considera que a adjudicação está no coração dos fenômenos de legal process, isso não por ser a mais frequente, mas por ser: 1. um recurso em potencial - uma ameaça ou escape; 2. um parâmetro para a barganha ou regulação em outros foros; 3 . um modelo para outros processos; 4. um símbolo de valores dominantes e uma fonte de legitimidade para normas, atividades, atos, dentre outros. Cf. Cf. GALANTER, Adjudication cit, p. 153.
} 
Até este ponto, não há nada de novo em relação aos meios autocompositivos. O que o primeiro capítulo deste trabalho visa a fazer de diferente é lançar luz e foco para o processo de mediação, ou seja, para suas bases constitutivas ${ }^{15}$, e para isso é feita uma comparação entre o processo de mediação e o processo judicial, a partir dos elementos subjetivo, objetivo e procedimental, dimensões que compõem a relação processual.

A finalidade da comparação é também colocar a mediação e o processo judicial no mesmo plano, a título de formas de solução de conflitos ou métodos de trabalho, e considerá-los à luz da teoria geral do processo, como dois tipos de processos instrumentais e a serviço da pacificação social.

Rompida a fase de sincretismo jurídico, caracterizado pela confusão entre os planos substancial e processual do ordenamento estatal, foi reconhecida a autonomia da ação e da relação jurídica processual, que se distingue da de direito substancial pelos seus sujeitos, seus pressupostos e seu objeto ${ }^{16}$. Sendo relações distintas, o juiz precisa decidir não somente sobre a existência do direito controvertido, mas também, para conhecê-lo, deve examinar se concorrem os requisitos de existência da própria relação jurídica processual, que são os pressupostos processuais, sistematizados por Oscar Von Bülow em sua obra sobre a teoria das exceções e dos pressupostos processuais $(1868)^{17}$.

Caracterizada a insatisfação de alguma pessoa em razão de uma pretensão que não pode ser, ou de qualquer modo não foi, satisfeita (pretensão resistida), o Estado poderá ser chamado a desempenhar a sua função jurisdicional; e ele o fará com ambas as partes envolvidas no conflito ou com uma só delas (o demandado pode ficar revel), segundo um método de trabalho estabelecido em normas adequadas. A essa soma de atividades em

\footnotetext{
15 Jean François Six alerta para a busca da identidade e o risco de banalização da mediação, termo utilizado para tudo e em todas as direções, idealizando o seu potencial e a sua aplicação. Segundo Six, é urgente relativizar a mediação, é a melhor maneira de não a destruir, pois ao se fazer angélica e messiânica a tal ponto, ela perderia muito rápido todo o crédito, toda a densidade. Cf. SIX, Jean François. Dinâmica da Mediação. Tradução Aguida Arruda Barbosa, Eliana Nazareth e Giselle Groeninga. Belo Horizonte: Del Rey, 2001, p. 167.

${ }_{16}$ Sobre os três momentos metodológicos do direito processual (de sincretismo, autonomia e instrumentalidade) vide DINAMARCO, Cândido Rangel. A instrumentalidade do processo. São Paulo: Malheiros, 2008, pp. 17-25.

${ }^{17}$ BÜLOW, Oskar Von. La teoría de las excepciones procesales y los presupuestos procesales, Tradução Miguel Angel Rosas Lichtschein, Buenos Aires: EJEA Ediciones Jurídica, 1964, pp. 1-17, 292-302.
} 
cooperação e de poderes, faculdades, deveres, ônus e sujeições que impulsionam essa atividade, dá-se o nome de processo ${ }^{18}$.

Várias conquistas e importantes debates ocorreram na fase de busca pela autonomia científica do direito processual, com foco na perspectiva publicista do processo e nos avanços da técnica processual, mas na atualidade o processo é considerado instrumental, visto a partir de seus ângulos externos e como instrumento para o acesso à ordem jurídica justa $^{19}$. É nesse contexto de instrumentalidade que a mediação deve-se inserir no Judiciário, e colocá-la no mesmo plano do processo judicial, a título de formas de solução de conflitos ou métodos de trabalho, não significa defender a autonomia do processo de mediação em relação ao direito material, tal como aconteceu no que diz respeito à relação jurídico processual e à autonomia da ação.

Conforme ressaltam Cintra, Dinamarco e Grinover, processo é conceito que transcende ao direito processual, sendo instrumento para o legítimo exercício de poder e que está presente em atividades estatais e não estatais ${ }^{20}$.

A teoria geral do processo não abrange somente os processos em que se exerce a jurisdição (civil, trabalhista, penal), nem apenas os processos estatais (jurisdicionais ou não jurisdicionais), mas também os processos das entidades intermediárias (partidos políticos, sindicatos, associações, sociedades civis e comerciais). Dinamarco ressalta que a sua extensão deve ser metodologicamente útil, nem tão ampla, a ponto de a generalidade minar

${ }^{18}$ Cf. CINTRA, Antônio Carlos de Araújo, GRINOVER, Ada Pellegrini; DINAMARCO, Cândido Rangel. Teoria Geral do Processo. São Paulo: Malheiros Editores, 2005, p. 42. Ainda conforme estes autores, não há incompatibilidade entre o processo como relação jurídica e o processo como procedimento em contraditório, este último assim conceituado por Elio Fazzalari em tempos mais recentes, pois "na realidade, a presença da relação jurídico processual no processo é a projeção jurídica e instrumentação técnica da exigência político constitucional do contraditório". Seriam apenas duas facetas da mesma realidade, podendo-se afirmar que "o processo é o procedimento realizado mediante o desenvolvimento da relação entre seus sujeitos, presente o contraditório". Ibidem, p. 293.

${ }^{19}$ Sobre o direito de acesso à justiça como direito de acesso à ordem jurídica justa, vide WATANABE, Kazuo. Acesso à Justiça e Sociedade Moderna. In: GRINOVER, Ada Pellegrini, DINAMARCO, Candido Rangel e WATANABE, Kazuo (Org.). Participação e Processo. São Paulo, Revista dos Tribunais, 1988, pp. 128-135. Segundo Dinamarco, a instrumentalidade do processo, vista inclusive como um novo método de pensamento do processualista contemporâneo, vai deixando as posturas puramente técnicas e dogmáticas que desempenharam seu relevantíssimo papel a partir da fundação da ciência do processo na segunda metade do século XIX, superando os males do sincretismo multisecular, mas que agora já cumpriu o seu ciclo de vida, sendo proposta nova perspectiva para encarar o sistema processual a partir de ângulos externos (seus escopos social, político e jurídico), sem prejuízo da instrospecção do sistema. Cf. DINAMARCO, Instrumentalidade cit, pp. 365-366 e passim.

${ }^{20}$ CINTRA, GRINOVER, DINAMARCO, Teoria Geral cit., p. 286-288. 
a sua utilidade metodológica, nem tão restrita: o critério para a determinação do âmbito da teoria geral do processo, com visos de unidade metodológica, é o exercício do poder, não chegando ela até aos processos relativos aos negócios jurídicos (como sustenta parte da doutrina), porque ali inexiste poder exercido ${ }^{21}$.

Segundo Barbosa Moreira, boas razões induzem a preferir delimitação conceitual restritiva do processo. $\mathrm{O}$ autor trata desta questão ao se referir à definição de Fazzalari de processo como o procedimento desenvolvido em contraditório. Afinal de contas, diz Barbosa Moreira, até em uma deliberação familiar é possível, não raro, encontrar esta característica (o pai ouve ambos os filhos em disputa, antes de decidir), mas não há vantagem alguma, teórica ou prática, em carrear fenômenos do gênero para o âmbito processual $^{22}$.

A pergunta é: há razões e vantagens, teóricas ou práticas, para incluir a mediação no âmbito da teoria geral do processo? Uma das hipóteses desta tese é de que sim. A mediação é um processo autocompositivo através do qual as próprias partes se responsabilizam pela decisão gerada, havendo a figura de um terceiro facilitador do diálogo e da solução do conflito entre as partes (mediador). As partes assumem um papel protagonista na solução do conflito, com a facilitação de terceiro, que poderá assumir também outros papéis e atribuições, conforme se verá a seguir, sob as lentes das diferentes Escolas de Mediação ${ }^{23}$. Há relações de poder, procedimento em contraditório, princípios, valores e garantias a serem resguardados e sistematizados sob uma teoria geral. Isso principalmente quando a mediação é institucionalizada, como ocorre no ambiente judicial, havendo regulação do processo e coercibilidade do acordo que, uma vez homologado pelo juiz, transforma-se em título executivo judicial.

${ }^{21}$ Cf. DINAMARCO, Instrumentalidade cit, pp. 73-77/370. Segundo Dinamarco, o que a teoria geral do processo postula é, resumidamente, a visão metodológica unitária do direito processual. Unidade de método não implica homogeneidade de soluções. Pelo método indutivo, ela chegou à instrumentalidade do processo como nota central de todo o sistema e tendência metodológica do direito processual contemporâneo como um todo; a visão instrumentalista, alimentada pela comprovação que a teoria geral fornece, é o vento mais profícuo da atualidade, em direito processual. Ibidem, p. 87.

${ }_{22}$ Barbosa Moreira, José Carlos, Privatização do Processo? In: Temas de Direito Processual Civil - sétima série, São Paulo, Saraiva, 2001, p. 11 (nota de rodapé 8).

${ }^{23}$ De acordo com o regulamento modelo para mediação do CONIMA, a mediação é definida como "um processo não-adversarial e voluntário de resolução de controvérsias por intermédio do qual duas ou mais pessoas, físicas ou jurídicas, buscam obter uma solução consensual que possibilite preservar o relacionamento entre elas. Para isso, recorrem a um terceiro facilitador, o mediador-especialista imparcial, competente, diligente, com credibilidade e comprometido com o sigilo, que estimule, viabilize a comunicação e auxilie na busca da identificação dos reais interesses envolvidos". 
Considerado o processo como um método de trabalho ${ }^{24}$, é possível levar em conta e comparar os elementos objetivos, subjetivos e procedimentais da mediação e do processo judicial, ou seja, a relação entre os sujeitos processuais (partes, juiz, mediador), o objeto do processo (mediato e imediato) e a marcha procedimental destes dois meios de solução de conflitos.

Na mediação evita-se a polarização entre o vitorioso e o derrotado da demanda (substituição do winner-takes-all pelo win-win), além de garantir-se maior criatividade no processo decisório, com a chance de pensar "outside the box" e construir consensualmente a decisão (tailored decision) ${ }^{25}$. Ela é diferente da negociação (bilateral, sem a figura do terceiro) e do julgamento pelo juiz togado e pelo árbitro (meios heterocompositivos). Uma maior semelhança existe entre a mediação e a conciliação, ambos meios autocompositivos em que há a figura de terceiro (mediador ou conciliador), e cujas diferenças serão tratadas no item 2.5 deste trabalho.

Uma das características centrais da mediação é a sua flexibilidade procedimental, de forma que é o processo que deve se adequar ao conflito, e não o conflito ao processo (regra geral de "one size does not fit all"). Entretanto, conforme destacado acima, a existência de flexibilidade não equivale à ausência de forma e à ausência de relações de poder na mediação, havendo garantias mínimas a serem resguardadas. Não é possível se pensar em uma mediação sem voluntariedade, sem que ambas as partes sejam ouvidas com igualdade de oportunidades (contraditório) e sem um mediador imparcial e independente, havendo um devido processo legal mínimo a ser seguido, o que será analisado no item a seguir.

Segundo Carlos Alberto Salles, a assimilação pelo sistema jurídico brasileiro de mecanismos alternativos de solução de conflitos leva a uma nova consideração do próprio conceito de jurisdição, que recai sobre sua função de pacificação social e atividade

\footnotetext{
${ }^{24}$ Sobre o processo como um método de trabalho desenvolvido pelo Estado para permitir a solução de litígios, vide BEDAQUE, José Roberto dos Santos. Efetividade do Processo e Técnica processual. São Paulo: Malheiros, 2006, pp. 34-40

${ }^{25}$ Nesse sentido, destaca Juan Vezzulla que a filosofia da mediação é que as pessoas envolvidas num conflito são as que melhor sabem como resolvê-lo, sendo o mediador um profissional especialmente treinado para auxiliar o diálogo entre elas, investigando a fundo os problemas reais e ajudando a criar e a avaliar as opções de solução com critérios que assegurem aos mediados que o acordo resultante será justo, equitativo e durável. Cf. VEZUlLA, Juan Carlos. Mediação: Teoria e Prática; Guia para Utilizadores e Profissionais. Lisboa: Agora Publicações Ltda, 2001, p. 87.
} 
caracterizada enquanto método de solucionar disputas. O conceito de jurisdição passa a ter que contemplar mecanismos alternativos de solução de conflitos, dando novo sentido à garantia constitucional da inafastabilidade da jurisdição $\left(\mathrm{CF}\right.$, art. $\left.5^{\mathrm{o}}, \mathrm{XXXV}\right){ }^{26}$

Nesse mesmo sentido, considera Cândido Rangel Dinamarco que constitui tendência moderna o abandono do fetichismo da jurisdição e a adesão aos meios alternativos, ressaltando o escopo social da pacificação dos conflitos e do acesso à ordem jurídica justa em um sistema em que é estrela de primeira grandeza a preocupação com os resultados ${ }^{27}$.

Destaca Carlos Alberto Salles que o processo contemporâneo estaria caminhando fortemente na direção de assumir uma dupla finalidade: de propiciar condições para as partes chegarem a soluções de consenso e de produzir decisões imperativas. Essas finalidades tendem a se apresentar de maneira escalonada, tendo por primeiro objetivo o consenso. Não sendo esse possível, então, coloca-se a finalidade de proporcionar a

\footnotetext{
${ }^{26}$ Cf. SALLES, Carlos Alberto de. Mecanismos Alternativos de Solução de Controvérsias e Acesso à Justiça: a inafastabilidade da tutela jurisdicional recolocada. In: FUX, Luiz; NERY JR, Nelson, WAMBIER, Teresa (Org.). Processo e Constituição: Estudos em homenagem ao professor José Carlos Barbosa Moreira. São Paulo: RT, 2006, p. 784. Considerando os meios alternativos de resolução de conflitos como técnicas processuais voltadas ao atingimento dos escopos da jurisdição, definida amplamente como função pública voltada à pacificação de conflitos, e refletindo sobre a necessidade de uma política pública de incentivo ao uso destes métodos, com a conjunção de esforços de entes públicos e privados, sociedade civil e poder judiciário para a promoção dessa atividade pública não necessariamente estatal voltada aos meios alternativos de solução de conflitos, vide DEMARCHI, Mediação: proposta de implementação cit, passim. Segundo Juliana, "tem-se, em certa medida, a ampliação do objeto de estudo do processo civil. Tendo em vista a instrumentalidade substancial e a necessidade de se agregar novos institutos à consecução dos escopos do processo, analisa-se a viabilidade de os meios alternativos serem tratados não mais como meros equivalentes jurisdicionais, mas como ferramentas do próprio sistema processual para a consecução de seus escopos". Ibidem, p. 10.

${ }^{27}$ Nas palavras deste autor: "Constitui tendência moderna o abandono do fetichismo da jurisdição, que por muito tempo fechou a mente dos processualistas e os impediu de conhecer e buscar o aperfeiçoamento de outros meios de tutela às pessoas envolvidas em conflitos. Os meios alternativos para a solução destes ocupam hoje lugar de muito destaque na preocupação dos processualistas, dos quais vêm recebendo especial ênfase a conciliação e a arbitragem e, em tempos mais recentes, a mediação. Não visam a dar efetividade ao direito material, ou à atuação da vontade concreta da lei - isto é, não são movidos pelo escopo jurídico que por muitas décadas se apontou como a mola legitimadora do exercício da jurisdição pelo Estado. Mas, tanto quanto esta, têm o escopo pacificador que é o verdadeiro fator de legitimidade da jurisdição mesma no Estado moderno. Por isso é que, ao se falar do direito substancial como portador dos critérios para a tutela jurisdicional e ao examinar as técnicas processuais capazes de efetivá-la em casos concretos, é preciso sempre ressalvar esses meios alternativos. Não importa se são ou não fiéis ao direito substancial, em cada caso: o importante é que sejam aptos a pacificar as pessoas e eliminar seus conflitos, fazendo-lhes justiça. Afinal, tudo que interessa ao processualista moderno é o aclaramento e agilização dos meios de acesso à ordem jurídica justa, mediante um sistema em que figure como estrela de primeira grandeza a preocupação pelos resultados. Cf. DINAMARCO. Cândido Rangel. Fundamentos do processo civil moderno, v. 1. São Paulo: Malheiros, 2010, pp. 391-392.
} 
decisão ${ }^{28}$. Sobre a precedência das formas consensuais de solução de controvérsias em relação às adjudicatórias, considera este autor:

\begin{abstract}
As partes, ao resolverem consensualmente uma disputa pendente entre elas, podem chegar a uma solução melhor que aquela que seria adjudicada por um juiz ou árbitro. A esse propósito, cresce a consciência quanto aos predicados das soluções de consenso. Elas são menos disruptivas das relações entre as partes, podem ser alcançadas com maior imediatidade, são menos custosas para os interessados e para o sistema judicial, além de permitirem abranger a integralidade do conflito, isto é, o conjunto de controvérsias pendentes entre as partes - não apenas aquela levada a juízo ${ }^{29}$.
\end{abstract}

Segundo Salles, o processo surge como instrumento de controle do poder jurisdicional do Estado, mas a admissão do exercício desse poder fora dos limites do Estado, como no caso da arbitragem, traz a necessidade de pensar a regulamentação de procedimentos decisórios privados, suscetíveis de ampla margem de liberdade procedimental baseada na vontade das partes. O processo passa a colocar-se de maneira mais ampla, como mecanismo de regulação do exercício do poder em geral, não apenas do jurisdicional, mas também daquele existente em outras esferas de poder atuantes ou presentes na sociedade ${ }^{30}$.

\title{
2.2 Dimensões do processo de mediação
}

Para analisar e comparar a mediação ao processo judicial é inevitável ter em mente as dimensões subjetiva, objetiva e procedimental expostas no triângulo a seguir, pois não há como pensar em um processo ou método de solução de conflito sem pensar na relação entre as partes, no objeto do processo e no procedimento que regula o processo de tomada de decisão, quer seja consensual ou não, trazendo previsibilidade e segurança aos resultados gerados.

\footnotetext{
${ }^{28}$ Cf. SALLES, A arbitragem na solução de controvérsias contratuais cit, pp. 131-132.

${ }^{29}$ Ibidem, p. 143.

${ }^{30}$ Ibidem, pp. 153-154. Reconhece Carlos Salles que há um juízo de adequação em relação ao próprio processo, e a busca de adequação processual pode ser entendida em dois sentidos: primeiro, enquanto esforço interpretativo para uma melhor aplicação de uma norma processual, pertencente a um quadro normativo já estabelecido. Em segundo lugar, na condição de agente ativo na construção de desenhos processuais adequados para atender a situações específicas. Ibidem, p 155.
} 


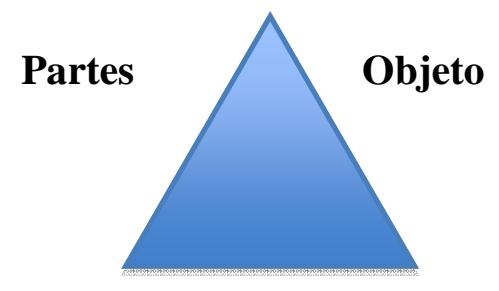

\section{Procedimento}

Estas três dimensões ${ }^{31}$, embora estejam acima ilustradas através dos diferentes lados do triângulo, se comunicam entre si. É o caso da relação sujeito vs. objeto e sujeito vs. sujeito na definição do objeto, pois estes elementos se misturam e a percepção do conflito pelas partes influi na própria delimitação deste conflito (dimensão linguística do conflito).

Às mesmas categorias (sujeitos, objeto e procedimento) podem ser atribuídos diferentes sentidos e funções, na mediação e no processo judicial. Trata-se de diferentes "engrenagens" que influem na adesão, na participação e mesmo no controle das partes em relação ao processo e ao resultado.

Não há dúvida de que o processo judicial e a mediação possuem sintaxes diferentes, a começar pelo fato de que se está comparando uma técnica heterocompositiva, com a participação direta do Estado (jurisdição estatal) a outra autocompositiva, com a participação consensual da partes e a presença indireta do Estado (no caso de a mediação ser realizada no ambiente judicial), mas se acredita que apesar de diferentes, é possível que o diálogo entre elas seja feito sob a teoria geral do processo $^{32}$.

\footnotetext{
${ }^{31}$ Este enfoque teve também por base a concepção estrutural do conflito denominada de triângulo de satisfação (LEDERACH, John Paul. Enredos, pleitos y problemas: Una guía práctica para ayudar a resolver conflictos. Guatemala: Ediciones Clara-Semilla, 1992). É chamado assim porque na medida em que os interesses das três dimensões sejam alcançados, tender-se-ia à satisfação das partes. Trata-se de um marco conceitual para se analisar os conflitos e elaborar estratégias de intervenção que possam satisfazer as expectativas, os interesses e necessidades das partes do conflito. Nesse sentido, os três elementos básicos de um processo de resolução de conflitos seriam: a) as pessoas; b) o processo; c) o problema (Manual de Teorias Básicas de Análisis y Resolución de Conflictos. Produzido no Sexto ICAR/OEA Taller de Verano: La investigación Acadêmica y La Práctica de La Resolución de Conflictos Sociales: ampliando el campo, 8 al 21 de junio de 2008, Arlington, VA, p. 11)

${ }^{32}$ Considerando a mediação como processo, deve-se tratar a mesma sob a perspectiva da teoria geral do processo, ou é o processo judicial que, junto com a mediação, deve ser considerado sob a perspectiva da teoria geral do conflito? Existe uma teoria geral do conflito? Qual seria a sua relação com a teoria geral do processo? Qual deve ser o pólo metodológico ou centro gavitacional destas teorias: o processo ou o conflito? Estas são perguntas de difícil resposta, e que inevitavelmente enveredam para uma dimensão linguística do conflito, um universo importante a ser explorado, e que transcende aos limites deste trabalho.
} 


\section{a) Sujeitos}

O processo judicial apresenta pelo menos três sujeitos: autor e réu, como sujeitos parciais, e juiz, como sujeito imparcial. Cintra, Dinamarco e Grinover destacam, todavia, que esta configuração subjetiva tríplice representa um esquema mínimo e simplificado, que não esgota a realidade atinente aos sujeitos que atuam no processo, sendo também sujeitos os auxiliares da justiça, os advogados, além da possibilidade de haver a ampliação subjetiva da relação processual através do litisconsórcio e do ingresso de terceiros no processo $^{33}$.

O conceito de parte, em sentido processual, é relevante para a garantia de voz na definição do objeto litigioso do processo, bem como para fins de vinculação à coisa julgada (CPC, art. 472), muito embora os efeitos da sentença possam atingir terceiros. ${ }^{34}$

Nem todo aquele que é titular do direito material é parte processual. Para estar em juízo, as partes precisam atender a pressupostos processuais subjetivos (como as capacidades de ser parte, processual e postulatória) e condições da ação (legitimidade, interesse de agir e possibilidade jurídica do pedido), tornando-se partes, em sentido processual.

Quanto à definição processual de parte, Liebman considera que são partes do processo os sujeitos do contraditório instituído perante o Juiz ${ }^{35}$, conceito que segundo Dinamarco supera o de Chiovenda que define parte como aquele que pede, aquele em cujo nome é pedida e aquele em relação ao qual se pede a atuação da vontade concreta da lei ${ }^{36}$.

Essa distinção de partes em sentido processual e em sentido material não está presente da mesma forma na mediação, mas isso não significa que a mediação prescinda de alguma delimitação subjetiva, ainda mais quando ocorre no ambiente institucional do

\footnotetext{
${ }^{33}$ CINTRA, GRINOVER, DINAMARCO, Teoria Geral cit., pp. 301/304.

${ }^{34}$ Sobre a distinção entre autoridade da sentença (em relação às partes) e os efeitos da sentença (em relação a terceiros), vide LIEBMAN, Enrico Tullio. Eficácia e Autoridade da Sentença e outros escritos sobre a Coisa Julgada. Tradução de Alfredo Buzaid e Benvindo Aires, tradução de textos posteriores à edição de 1945 de Ada Pellegrini Grinover. $4^{\text {a }}$ edição. Rio de Janeiro: Forense, 2006, passim.

${ }^{35}$ LIEBMAN, Enrico Tullio. Manual de Direito Processual Civil. Vol. I, $3^{\text {a }}$ edição. Tradução e notas de Cândido Rangel Dinamarco. São Paulo: Malheiros, 2005, p. 123.

${ }^{36}$ DINAMARCO, Cândido Rangel. Litisconsórcio. São Paulo: Malheiros, 2009, p. 23.
} 
Judiciário, onde tendem a estar mais delimitados os seus contornos, o objeto sobre o qual incide e os sujeitos que participam do processo.

Em sentido amplo, os sujeitos da mediação são as partes em conflito, seus advogados (quando as partes forem assistidas ou representadas pelos mesmos), o juiz, o mediador / conciliador e os auxiliares da Justiça. Cada um tem determinado papel e exerce algum nível de controle sobre o processo e sobre o resultado do litígio. A mediação não funcionaria sob revelia, pois o seu processo depende (de forma constitutiva) da atuação de ambas as partes.

As diferentes perspectivas e papéis que esses atores exercem no processo de mediação estão expostos na pesquisa empírica deste trabalho, nos quadros comparativos dos itens 4.2 e 5.2 .

\section{b) Objeto: Conflito vs. Disputa}

No processo judicial, através da demanda, o autor apresenta o pedido em relação ao qual o réu se defende, havendo um conflito de interesses qualificado pela pretensão de um dos litigantes e pela resistência do outro ${ }^{37}$.

O conceito de conflito sociológico não se confunde com o de conflito jurídico ${ }^{38}$. Segundo Liebman, o jurista, e de modo especial o processualista, só pode cuidar dos processos efetivamente propostos e das lides que forem realmente levadas perante os Juízes, e na exata medida em que o forem. O objeto do processo não seria o conflito de

\footnotetext{
${ }^{37}$ A lide, conceito Carneluttiano, é mencionada na exposição de motivos do $\mathrm{CPC} / 73$, que a define como mérito da causa, seu objeto, onde se exprimem as aspirações em conflito de ambos os litigantes. Entretanto, há críticas quanto à adoção do conceito de lide, pois o mesmo não se adequaria às hipóteses de revelia e de reconhecimento do pedido, em que não há contraposição de pretensões, ou seja, resistência do réu, o mesmo em momento anterior à contestação e no processo executivo. Sobre o recorte e formalização do conflito através dos elementos objetivos da demanda, no processo civil individual e coletivo, vide GABBAY, Daniela Monteiro. Pedido e Causa de Pedir. São Paulo: Saraiva, 2010, passim.

${ }^{38}$ Sobre o debate entre Carnelutti e Calamandrei acerca do conteúdo material do processo, sob a perspectiva do conflito jurídico e do conflito sociológico, do processo integral e processo parcial, vide CARNELUTTI, Francesco. Lite e funzione processuale. Rivista di Diritto Processuale Civile, 1928, parte prima, pp. 2829/31/34 e CALAMANDREI, Piero. Il concetto di 'lite' nel pensiero di Francesco Carnelutti. Rivista di Diritto Processuale Civile, 1928, parte prima, pp. 91-96.
} 
interesses em sua simples e natural realidade. Só em face do pedido do autor é que o juiz pode intervir, examinar o caso e julgar, de acordo com a lei, se esse pedido é ou não procedente, concedendo ou negando em consequência a providência pedida. A lei dá ao autor a liberdade, a iniciativa e a responsabilidade da escolha no modo de resolver a controvérsia, exigindo dele a indicação da forma concreta e determinada de tutela que pretende conseguir para a satisfação de seu interesse. A tarefa do juiz é unicamente decidir se a solução proposta é conforme ou não com o direito vigente. Ainda nas palavras de Liebman:

\begin{abstract}
O autor que quiser levar perante o Juiz um conflito de interesses do qual é parte deve, por assim dizer, construí-lo juridicamente, determinando a forma de tutela jurisdicional que ele pretende conseguir como consequência lógica dos fatos que afirmou existentes. Desse modo, o conflito de interesses não entra para o processo tal como se manifestou na vida real, mas só indiretamente, na feição e configuração que lhe deu o autor em seu pedido. Por sua vez, o Juiz não age diretamente sobre o conflito, não o compõe - como diz Carnelutti, pois que ele constitui uma realidade psicológica praticamente inatingível: o que o Juiz faz é verificar a procedência do pedido que lhe foi feito para, consequentemente, conceder-lhe ou negar-lhe deferimento, em aplicação do que a lei manda e preceitua $^{39}$.
\end{abstract}

Já para a mediação, o conflito é definido de forma diferente, sem as mesmas molduras e separações entre o âmbito processual e o substancial. A mediação parte da premissa de que o conflito é parte normal da interação humana, e pode ser construtivo.

Enquanto o processo judicial visa a eliminar e pacificar os conflitos (seu escopo social), nos moldes do que foi levado ao Judiciário através do objeto litigioso, a mediação trata os conflitos sob ótica diferenciada, vendo ao mesmo tempo aspectos de perigo e oportunidade.

Este trabalho não objetiva adotar uma definição única de conflito, nem avaliar as já existentes, mas um breve mapeamento de alguns conceitos já revela que o conflito objeto da mediação não se enquadra na mesma moldura do objeto litigioso do processo civil, que atua predominantemente no nível da disputa.

Conforme Marinés Suares, no campo da mediação o conflito pode ser definido como um processo interrelacional, que se dá entre duas ou mais partes, e no qual

\footnotetext{
${ }^{39}$ LIEBMAN, Enrico Tullio. O despacho saneador e o julgamento do mérito. Revista dos Tribunais, vol. 767, ano 88 , set/1999, pp. 744-745.
} 
predominam as relações antagônicas entre as mesmas através de suas ações, pensamentos, afetos ou discursos, que algumas vezes podem também ser agressivos, sendo o processo de mediação co-construído pelas partes e pelo mediador. O conflito seria este processo complexo, dificilmente abarcado dentro de uma única definição, e a disputa, por outro lado, é uma parte deste processo, que pode ser caracterizada como uma fase pública e aparente do processo de conflito ${ }^{40}$.

De acordo com o Manual de Teorias Básicas de Análisis y Resolución de Conflictos, "o conflito é uma dissonância, supostamente incompatível, entre entes sociais ou partes interdependentes, sobre a distribuição de recursos materiais ou simbólicos e na qual as partes atuam baseando-se em percepções mútuas de que seus objetivos são incompatíveis ou contraditórios ${ }^{41}$.

A OEA-PROPAZ ${ }^{42}$ elaborou a seguinte definição, que faz referência a várias dimensões do conflito: "é uma luta expressada (dimensão comunicativa) entre duas ou mais pessoas (dimensão sociológica) que dependem entre si e que, na busca de satisfazer seus interesses ou necessidades, se encontram com recursos escassos (dimensão sócioeconômica) ou que parecem (dimensão psicológica) escassos e metas contrapostas (dimensão ideológica) ou que obstaculizam entre si (dimensão sóciointerativa)" ${ }^{43}$

Para Antônio Freitas Jr., os conflitos que interessam ao direito, à sociologia, às políticas públicas em geral e às políticas de justiça em particular, são os conflitos de justiça, que assim conceitua: "são as situações em que estejam presentes, simultaneamente, i. no plano objetivo: um problema alocativo incidente sobre bens tidos por escassos ou encargos tidos como necessários, sejam os bens e os encargos de natureza material ou imaterial; ii. no plano comportamental: consciente ou inconsciente, intencional ou não, contraposição no vetor de conduta entre dois sujeitos e; iii. No plano anímico ou

\footnotetext{
${ }^{40}$ SUARES, Marinés. Mediación: conducción de disputas, comumicación y técnicas. Buenos Aires, Paidós, 2008, pp. 78-79.

${ }^{41}$ Manual de Teorias Básicas cit, 2008, p. 3.

42 OEA-PROPAZ foi um programa da OEA na Guatemala entre os anos de 1997 e 2003 cujo objetivo foi reforçar o processo de paz na Guatemala oferecendo ajuda técnica para o desenvolvimento de capacitação para a resolução pacífica de conflitos em diversos níveis da sociedade. Em 2003 o programa cumpriu os objetivos propostos e se transformou em uma ONG nacional chamada Fundação Propaz.

${ }^{43}$ Manual de Teorias Básicas cit, 2008, pp. 9-10.
} 
motivacional: sujeitos portadores de percepções diferentes sobre como tratar o problema alocativo, como função de valores de justiça" ${ }^{\text {"44 }}$.

Sustenta-se que há diferença entre o conflito e a disputa, esta última mais relacionada ao processo judicial, refletindo de certa forma a diferença entre lide sociológica e lide processual, nos estudos sobre o conteúdo do processo realizados por Carnelutti e Calamandrei.

Destaca Alexandre Araújo Costa a importância de distinguir conflito de disputa, sendo a disputa uma mera faceta do conflito, que pode ser muito mais complexo:

\begin{abstract}
Uma das percepções fundamentais é a de que a disputa não é o conflito, mas uma decorrência do conflito. Portanto, resolver a disputa não põe fim ao conflito subjacente. Quando um juiz determina com quem ficará a guarda de um filho, isso põe fim a uma determinada disputa, mas além de não resolver a relação conflituosa, muitas vezes acirra o próprio conflito, criando novas dificuldades para os pais e para os filhos. Então, torna-se claro que o conflito, ao menos em muitos casos, não pode ser resolvido pelo acordo.

(...)

Mas o que fazer quando o conflito não é uma disputa por um determinado bem, mas o resultado de uma percepção diferente do mundo? Que fazer quando se confrontam um marido que repete padrões patriarcais e uma mulher que o ama, mas tenta conquistar sua liberdade e autonomia? Ou quando desejamos aquilo que não é quantificável, como atenção, carinho ou um pedido de desculpas? Ou aquilo que nenhum acordo é capaz de criar, por envolver respeito, afeto, cuidado, ou qualquer coisa que envolva um sentimento sincero? Nessas situações, os modelos de disputa falham, justamente porque há conflito sem haver propriamente disputa. O que está em jogo são desejos inconciliáveis por serem divergentes e não por convergirem em relação a um bem disputado ${ }^{45}$.
\end{abstract}

Há uma dimensão linguística do conflito a ser considerada ${ }^{46}$. Os conflitos são constituídos pela nossa percepção das relações vividas, que são reconstruídas linguisticamente dentro de uma narrativa pessoal. Nessa medida, alterar a percepção que uma pessoa tem do conflito significa modificar o próprio conflito, pois é possível

\footnotetext{
${ }^{44}$ FREITAS JR., Antonio Rodrigues de. Conflitos de Justiça e limites da mediação para a difusão da cultura da paz. In: SALLES, Carlos A (Org). As Grandes Transformações do Processo Civil Brasileiro. Homenagem ao Prof. Kazuo Watanabe. São Paulo: Quartier Latin, 2009, p. 518.

${ }^{45}$ COSTA, Alexandre Araújo. Cartografia dos métodos de composição de conflitos. In: AZEVEDO, André Gomma de (Org.). Estudos em Arbitragem, Mediação e Negociação, v. 3, Brasília: Grupos de Pesquisa, 2004, pp.163-164.

${ }^{46}$ Sobre o tema vide MATHER, Lynn. Yngvesson. Language, audience, and the transformation of disputes. Law and Society Review, vol. 15, n. 3-4, 1980-1981, pp. 775-821. FELSTINER, William, ABEL, Richard L., SARAT, Austin. The emergence and transformation of disputes: naming, blaming, claiming, Law and society review, v. 15, n. 3-4, 1980-81, pp. 631-654. Sobre os reflexos da linguagem na formulação do pedido e configuração do conflito, nas demandas coletivas e individuais, vide GABBAY, Pedido e causa de pedir cit., pp. 33-40.
} 
modificar o modo de comportamento entre as pessoas nele envolvidas ${ }^{47}$. Ressalta Araújo Costa que como elaboramos linguisticamente a própria realidade (ou ao menos a linguagem é um elemento importante na percepção do que chamamos de realidade), é possível intervir na própria maneira como pensamos o nosso conflito ${ }^{48}$.

A mediação tem esse potencial de transformação das relações sociais, que será tratado no item 2.6 deste trabalho, ao se analisar a Escola de Mediação Transformativa.

Considera Boaventura Santos que só a mediação poderia subverter a separação entre o conflito processado e o conflito real, separação que domina a estrutura processual do direito do estado capitalista e que é a principal responsável pela superficialização da conflituosidade social na sua expressão jurídica ${ }^{49}$.

\section{c) Processo: o devido processo legal mínimo na mediação}

A dinâmica contenciosa e adversarial do processo judicial (right based approach) difere da dinâmica não adversarial da mediação (interested based approach), muito embora a flexibilidade procedimental desta última não seja equivalente à ausência de forma, conforme já exposto neste trabalho. Há um mínimo de procedimento que deve ser garantido, e dificilmente alguém discordaria do fato de que na mediação deva haver imparcialidade do mediador ${ }^{50}$, voluntariedade das partes $^{51}$ e contraditório entre elas, resguardando-se a igualdade (substancial e não meramente formal) de oportunidades de participação no processo.

\footnotetext{
47 A maneira pela qual conceituamos um conflito influi na maneira como o resolvemos, e aprendemos a responder aos conflitos através das experiências e referenciais do ambiente em que vivemos. Cf. Manual de Teorias Básicas cit., p. 3.

${ }^{48}$ COSTA, Cartografia dos métodos cit., p.164.

${ }^{49}$ SANTOS, Boaventura de Souza. O discurso e o poder. Porto Alegre: Fabris, 1988, p. 23.

${ }^{50} \mathrm{O}$ papel do mediador normalmente é de facilitador da comunicação e solução do conflito entre as partes, mas, ainda que assuma papel avaliador, não pode decidir o conflito, pois do contrário a autocomposição se transformaria em heterocomposição. Tanto na hipótese de um mediador facilitador quanto de avaliador, a imparcialidade e independência são requisitos necessários, inclusive para resguardar a igualdade de tratamento das partes. Juliana Demarchi destaca que a mediação avaliativa pode ser considerada procedimento misto, que agrega à prática da mediação técnicas próprias da avaliação neutra de terceiro. Cf. DEMARCHI, Mediação: proposta de implementação cit., p. 140.

${ }^{51}$ Mesmo no caso da mediação obrigatória, a obrigatoriedade está relacionada à submissão das partes ao processo de mediação (getting the parties to the table), e não à forma de participação no curso do processo ou à necessidade de obtenção de um acordo.
} 
O devido processo legal é frequentemente tratado em relação aos meios heterocompositivos, como nos processos judiciais e arbitrais, sendo uma garantia de contenção do exercício de poder e autoridade, quer das partes, quer de terceiro. Poder-se-ia falar, também, em devido processo legal para os meios autocompositivos, como na mediação e conciliação ${ }^{52}$

Entende-se neste trabalho que sim, muito embora o devido processo legal na mediação deva ser colocado em termos mínimos, sem gerar uma procedimentalização ou formalização excessiva que vá de encontro à autonomia e flexibilidade do desenho processual da mediação. Esses contornos mínimos são dados pela norma constitucional (garantias processuais), e fazem com que as formas autocompositivas possam ser tratadas à luz da teoria geral do processo.

Os incisos LIV e LV, do art. $5^{\circ}$ da $\mathrm{CF} / 88$, determinam, respectivamente, que "ninguém será privado da liberdade ou de seus bens sem o devido processo legal" e que "aos litigantes, em processo judicial ou administrativo, e aos acusados em geral são assegurados o contraditório e a ampla defesa, com os meios e recursos a ela inerentes". Ambos são garantias constitucionais do processo ${ }^{53}$.

$\mathrm{Na}$ lei de arbitragem brasileira (Lei $\mathrm{n}^{\circ}$ 9307/96), o devido processo legal é tratado no capítulo destinado ao procedimento arbitral, determinando-se que "serão, sempre, respeitados no procedimento arbitral os princípios do contraditório, da igualdade das partes, da imparcialidade do árbitro e de seu livre convencimento" (art. 19, p. 2) ${ }^{54}$.

A garantia constitucional do devido processo legal na Constituição brasileira tem uma redação semelhante à parte final da Emenda Constitucional $n^{\circ} 14$, 1a seção, da

\footnotetext{
${ }^{52}$ A determinação de padrões e garantias mínimas aos meios alternativos de solução de conflitos é uma questão também levantada por Cappelletti, para evitar-se o risco de que a alternativa proporcione uma justiça de segunda classe. Cf. CAPPELLETTI, Mauro. Os métodos alternativos de solução de conflitos no quadro do movimento universal de acesso à justiça. Revista de Processo, n. 74, abr-jun. 1994, p. 89.

53 Sobre as garantias constitucionais no processo civil, especialmente o devido processo legal, vide GRINOVER, Ada Pellegrini. As garantias constitucionais do direito de ação. São Paulo: Revista dos Tribunais, 1973, passim.

${ }^{54}$ Sobre o devido processo legal mínimo, estabelecido pelo art. 21 da lei de arbitragem e por princípios constitucionais, e que funciona como um limite à autonomia da vontade na arbitragem, vide SALLES, $A$ arbitragem na solução de controvérsias contratuais cit., pp. 389/399-402 e ALVES, Rafael Francisco. O devido processo legal na arbitragem. In: JOBIM, Eduardo; MACHADO, Rafael Bicca (Coord.). Arbitragem no Brasil: aspectos relevantes. São Paulo: Quartier Latin, 2008, pp. 381-416, este último autor considerando que a imparcialidade do árbitro não integra o devido processo legal.
} 
Constituição norte-americana, que determina que "todas as pessoas nascidas ou naturalizadas nos EUA, e sujeitas à sua jurisdição, são cidadãos dos EUA e do Estado em que residem. Nenhum Estado pode criar ou implementar leis que limitem os privilégios ou imunidades dos cidadãos dos EUA; nem pode o Estado privar nenhuma pessoa de sua vida, liberdade e propriedade sem o devido processo legal, nem negar a nenhuma pessoa dentro de sua jurisdição a proteção igualitária das leis"

Em 1969, a Suprema Corte norte-americana criou importante precedente ao decidir o caso Goldberg v. Kelly, que tratou das garantias do devido processo legal (due process), relacionadas ao contraditório (direito de ser ouvido e de se defender, com efetiva oportunidade de participar do processo) e à imparcialidade e independência do órgão julgador, que deve motivar suas decisões ${ }^{56}$.

Ainda que na mediação não haja um poder-dever de decidir o conflito exercido por terceiro (como no caso da arbitragem e do processo judicial), o que exclui qualquer necessidade de o mediador demonstrar seu livre convencimento e motivar suas manifestações, há uma relação entre as partes a ser regulada por garantias mínimas referentes à imparcialidade do terceiro, à voluntariedade das partes e à igualdade (substancial e não meramente formal) de oportunidades de participação no processo, representada pelo contraditório.

\footnotetext{
55 Tradução livre. No original: All persons born or naturalized in the United States, and subject to the jurisdiction thereof, are citizens of the United States and of the State wherein they reside. No State shall make or enforce any law which shall abridge the privileges or immunities of citizens of the United States; nor shall any State deprive any person of life, liberty, or property, without due process of law; nor deny to any person within its jurisdiction the equal protection of the laws. A Emenda Constitucional $\mathrm{n}^{\circ} 5$ também trata do devido processo legal, ao determinar que No person shall be held to answer for a capital, or otherwise infamous crime, unless on a presentment or indictment of a Grand Jury, except in cases arising in the land or naval forces, or in the Militia, when in actual service in time of War or public danger; nor shall any person be subject for the same offense to be twice put in jeopardy of life or limb; nor shall be compelled in any criminal case to be a witness against himself, nor be deprived of life, liberty, or property, without due process of law; nor shall private property be taken for public use, without just compensation.

${ }^{56}$ Ao analisar o direito de cidadãos de Nova Iorque de serem devidamente notificados e ouvidos neste processo, a Suprema Corte decidiu que a pretermination evidentiary hearing is necessary to provide the welfare recipient with procedural due process; (a) such hearing need not take the form of a judicial or quasijudicial trial, but the recipient must be provided with timely and adequate notice detailing the reasons for termination, and an effective opportunity to defend by confronting adverse witnesses and by presenting his own arguments and evidence orally before the decision maker; $(b)$ counsel need not be furnished at the pretermination hearing, but the recipient must be allowed to retain an attorney if he so desires; (c) the decisionmaker need not file a full opinion or make formal findings of fact or conclusions of law but should state the reasons for his determination and indicate the evidence he relied on; $(d)$ the decisionmaker must be impartial, and although prior involvement in some aspects of a case will not necessarily bar a welfare official from acting as decision maker, he should not have participated in making the determination under review.
} 
Na mediação realizada no Judiciário, revela-se também de grande importância a garantia de confidencialidade, sob pena de as demais garantias restarem prejudicadas. Assim, as informações reveladas na mediação não podem ser levadas ao processo judicial, nem pelo mediador nem pelas partes, e não são consideradas como elemento de prova. Os mediadores também não podem fazer relatório, avaliação ou recomendação para os juízes ou qualquer outra autoridade que tenha alguma relação com o caso levado à mediação, podendo apenas relatar se houve ou não acordo ${ }^{57}$.

A aplicação do devido processo legal aos meios alternativos de solução de conflitos foi a questão central de estudo realizado por Richard Reuben, que defende a existência de uma teoria unitária para os meios alternativos de solução de conflitos e para o processo judicial, orbitando em torno da constituição ${ }^{58}$.

Reuben considera que esta teoria unitária deve suplantar o modelo bipolar tradicional, que divide os sistemas de solução de conflitos em público e privado, e sujeita apenas o público, representado pelo processo civil judicial, ao devido processo legal. A partir da teoria unitária se reconhece que os meios alternativos de solução de conflitos são influenciados pela ação estatal, e por isso constitucionalmente seria requerido que se submetessem a um devido processo legal mínimo (nas palavras do autor: minimal but meaningful due process standards), relacionado à imparcialidade do terceiro, ao contraditório e ao direito a ser assistido por um advogado. Neste ambiente de pluralismo processual, o movimento da teoria unitária seria mais no sentido de publicização dos meios alternativos do que de privatização do processo judicial. Trata-se de teoria unitária de uma justiça civil pública ${ }^{59}$.

Reuben distingue os meios alternativos entre os que estão na esfera privada ou contratual e os que estão nos ambientes do Judiciário e das agências administrativas. Em qualquer hipótese o devido processo legal se aplicaria, ainda que em medida diversa, mas estes últimos estariam sob maior influência da ação estatal. É nesse contexto que se

\footnotetext{
${ }^{57}$ Nos EUA há uma diferença entre confidentiality e privilege: confidentiality está relacionada ao que as partes mantêm em sigilo em relação a familiares, amigos e outros, enquanto privelege está relacionado ao que é mantido em sigilo em relação ao Tribunal. Se as partes chegam a um acordo, apenas este resultado final pode ser apresentado e submetido ao Judiciário. A confidencialidade e o privilégio são protegidos pelo Uniform Mediation Act, pelas Federal Rules of Evidence, salvo algumas exceções previstas expressamente (casos envolvendo crime, por exemplo).

${ }^{58}$ REUBEN, Constitutional Gravity: a Unitary Theory cit, pp. 952-1104.

${ }^{59}$ Ibidem, pp. 952-954.
} 
encontram os programas de mediação anexos às Cortes, que são financiados e administrados pelo Judiciário, recebem os conflitos pela via judicial, contando com mediadores muitas vezes contratados ou empregados pelas Cortes, além de serem os acordos obtidos homologados judicialmente ${ }^{60}$.

O autor ilustra seus argumentos através de figura que se assemelha ao sistema solar, sendo o poder coercitivo estatal considerado o sol; e a força constitucional, o elemento gravitacional: quanto mais o processo de solução de conflitos se afasta do campo de ação do poder estatal, menor é o nível de força constitucional exercida sobre este processo. É por isso que a força constitucional é maior nos sistemas de adjudicação (processo judicial e em seguida o arbitral) e menor nos sistemas consensuais (como a mediação) e consultivos (como a avaliação neutra de terceiro) de solução de conflitos, assim como é maior quando estes mecanismos estão no ambiente institucional das Cortes do que no ambiente contratual e privado das partes ${ }^{61}$.

Um mínimo de devido processo legal ${ }^{62}$ não compromete a flexibilidade procedimental, sujeita ao consenso das partes, e a possibilidade de qualquer uma delas poder encerrar a mediação a qualquer tempo e por qualquer razão. Trata-se apenas de uma forma de reconhecer os contornos constitucionais e garantias aos meios alternativos de solução de conflitos, que também estão sujeitos ao campo de ação estatal. Quanto mais os meios alternativos se expandem no Judiciário, mais se confrontam com questões relacionadas ao devido processo legal ${ }^{63}$.

\footnotetext{
${ }^{60}$ Ibidem, pp. 954-955.

61 Ibidem, pp. 958 e 1048.

${ }^{62}$ Robert M. Cover reconhece a existência de um mínimo e transubstancial devido processo legal, com os contornos definidos pela constituição: it is extraordinary that our legal system holds a divided view of procedure: our norms for minimal process, expressed in the constitutional rubric of procedural due process, are generally conceded to constitute a substance-sensitive calibrated continuum in which the nature of the process due is connected to the nature of the substantive interest to be vindicated; yet our primary set of norms for optimal procedure, the procedure available in our courts of general jurisdiction, is assumed to be largely invariant with substance. It is by no means intuitively apparent that the procedural needs of a complex antitrust action, a simple automobile negligence case, a hard-fought school integration suit, and an environmental class action to restrain the building of a pipeline are sufficiently identical to be usefully encompassed in a single set of rules which makes virtually no distinctions among such cases in terms of available process. My point is not that the Federal Rules are not workable over such a broad range. But it may be worth asking in what sense that codification works well because of its trans-substantive aspiration, and in what sense it works in spite of it. Cf. COVER, Robert M. Reading the Rules: procedural neutrality and substantive efficacy. In: COVER, Robert M. e FISS, Owen M. (Orgs). The structure of procedure. Mineola: The Foundation Press, 1979, p. 80.

${ }^{63}$ Cf. REUBEN, Constitutional Gravity: a Unitary Theory cit, pp. 1103-1104.
} 
Diferentemente de um negócio jurídico ou transação que ocorrem fora do Judiciário, e cujo acordo pode ser homologado pelo juiz sem a preocupação com o procedimento que o gerou ${ }^{64}$, quando a mediação e a conciliação são realizadas em um ambiente institucional, público como o judicial ou mesmo o privado como o das Câmaras de Mediação e Arbitragem, o procedimento é regulado e visa a promover uma garantia de previsibilidade e segurança àqueles que participam da mediação. No caso das Câmaras, há o relevante papel dos regulamentos e dos termos contratuais em que as partes estabelecem as regras procedimentais; no caso da mediação e conciliação realizadas incidentalmente ao processo judicial, cujos casos são encaminhados pelo juiz (dentro de um campo de ação estatal, como destaca Reuben), há o papel dos provimentos e regulações no âmbito do Judiciário. Nestes ambientes institucionais, tanto o resultado como o procedimento importam. Trata-se da importante relação entre a justiça do processo e a justiça do resultado.

Além do ambiente institucional e das regras procedimentais, a presença do terceiro também faz diferença, e, no caso da mediação, cabe a este terceiro, além de facilitar a comunicação entre as partes, resguardar o cumprimento das regras procedimentais estabelecidas consensualmente pelas mesmas ${ }^{65}$.

A não observância deste devido processo legal mínimo pode ser causa para a invalidação do acordo obtido entre as partes (assim como ocorre em relação à sentença arbitral, quando não observado o devido processo legal, conforme prevê o art. 32, VII da Lei $\mathrm{n}^{\circ}$ 9307/96). Nesse caso, somando-se às garantias constitucionais previstas nos incisos LIV e LV do art. $5^{\circ}$ da $\mathrm{CF} / 88$, há em nível infraconstitucional garantias e regras fixadas em Regulamentos, Resoluções, Provimentos (dos Tribunais, por exemplo) e em nível

\footnotetext{
${ }^{64}$ De acordo com o art. 475-N, inciso V, do Código de Processo Civil, é título executivo judicial o acordo extrajudicial, de qualquer natureza, homologado judicialmente.

65 Martin Golding reconhece a necessária presença deste terceiro e traça distinção entre a negociação ou barganha bilateral e o que chama de jural-like forms of dispute settling, categoria na qual inclui a adjudicação, a conciliação (e mediação) e a integração terapêutica, sendo possível unificar as regras processuais aplicadas a estes mecanismos. Suas características são: (i) a dispute settler, a particular third party (who may be more than one individual) who "stands between"; (ii) particular disputants and settles, or attempts to settle; (iii) their particular dispute. There must be (iv) some kind of hearing of the dispute, the presentation to the third party of each disputant's side of the controversy. And $(v)$ the materials so received must be used by the third party in arriving at the settlement. Cf. GOLDING, Martin P. Dispute Settling and Justice. In: COVER, Robert M. e FISS, Owen M. (Orgs). The structure of procedure. Mineola: The Foundation Press, 1979, p. 106.
} 
contratual a existência de convenções entre as partes ${ }^{66}$, que precisam ser observados sob pena da parte que se sentir prejudicada (em relação ao processo ou ao resultado) buscar judicialmente a invalidação do acordo.

O Código de Ética estabelecido pela Resolução no 125/2010 do CNJ prevê os princípios e garantias fundamentais da mediação e conciliação judiciais (confidencialidade, competência, imparcialidade, neutralidade, independência, autonomia, respeito à ordem pública e às leis vigentes) e determina que as regras que regem o procedimento da conciliação/mediação são normas de conduta a serem observadas pelos conciliadores/mediadores para o seu bom desenvolvimento. Para tanto, eles devem assinar, no início da sessão, um termo de compromisso, submetendo-se às orientações do juiz coordenador da unidade a que vinculados. A sanção para o descumprimento dos princípios e regras estabelecidos no Código de Ética, bem como a condenação definitiva em processo criminal, é a exclusão do conciliador/mediador do respectivo cadastro e o impedimento para atuar nesta função em qualquer outro órgão do Poder Judiciário Nacional.

Quanto à base contratual dos mecanismos alternativos de solução de controvérsias, Carlos Alberto Salles destaca que no âmbito da Administração Pública norte-americana, assim como em relações privadas, a utilização destes mecanismos costuma ser precedida de uma espécie de contrato ou convenção, denominada de ADR Agreement. Neste instrumento contratual, as partes elegem uma técnica específica de solução de controvérsia, definem os parâmetros básicos de seu funcionamento, escolhem, se for o caso, o terceiro neutro, definem critérios para a distribuição de despesas, estabelecem o procedimento básico a ser seguido e realizam, com o auxílio de seus advogados, o desenho do mecanismo de solução de controvérsias ${ }^{67}$.

\footnotetext{
${ }^{66}$ Conforme Adolfo Braga Neto, a mediação caracteriza-se como um contrato de prestação de serviços, no qual de comum acordo as partes contratam um mediador para que as auxilie na busca de soluções para o conflito que estão enfrentando. Os requisitos mínimos deste contrato plurilaterial envolvem a qualificação das partes e de seus advogados, do mediador e co-mediador, regras claras estabelecidas para o procedimento, número indicativo de reuniões, honorários e despesas incorridas durante a mediação e formas de pagamento, confidencialidade relativa às informações e resultado da mediação. BRAGA NETO, Adolfo. Reflexões sobre a Conciliação e a Mediação de Conflitos. In: SALLES, Carlos Alberto de (Org.). As grandes transformações do processo civil brasileiro: homenagem ao professor Kazuo Watanabe. São Paulo: Quartier Latin, 2009, pp. 496-497.

${ }^{67}$ Cf. SALLES, A arbitragem na solução de controvérsias contratuais cit, pp. 250-251.
} 
Este mesmo autor ressalta a diferença entre a normatividade de um processo pronto e acabado e aquela na qual as regras processuais podem ser quase inteiramente construídas pela vontade das partes, e considera a existência de uma instrumentalidade metodológica que se volta aos problemas de cada campo específico do direito e da realidade fática. Pondera que o caráter transubstancial do processo, de atender indistintamente a um grande conjunto de tipos de situações controvertidas, pelo qual é tradicionalmente concebido, vem sendo colocado em xeque diante da crescente complexidade das situações fáticas e jurídicas da realidade contemporânea ${ }^{68}$.

Transposta a fase de experimentação dos meios alternativos de solução de conflitos no Judiciário, a tendência é haver maior atenção à regulação destes meios, o que também reflete sobre o seu devido processo legal. Nos Estados Unidos, o Uniform Mediation Act (UMA), de agosto de 2001, surgiu nesse contexto regulatório e se aplica tanto às mediações que ocorrem no Judiciário e nas Agências Administrativas quanto às mediações privadas. Regulamenta questões relacionadas à confidencialidade da mediação e à postura do mediador, que tem a obrigação de revelar previamente qualquer conflito de interesses com as partes e resguardar sigilo sobre o que foi objeto da mediação, sigilo que somente pode ser quebrado em hipóteses específicas ${ }^{69}$.

Além desta regulação mais geral e nacional, muitos programas de mediação anexos às Cortes têm uma regulação local, vigente no ambiente judiciário. É o caso dos programas de mediação do Judiciário da Flórida analisados na pesquisa empírica, com farta regulação: Florida Statutes, Rules of Civil Procedure, Florida Rules for Certified and Courtappointed Mediators, além de contarem com Comitês que atuam junto à Supreme CourtADR Policy and Rules, Ethics Advisory Committee, dentre outros.

\footnotetext{
${ }^{68}$ Ibidem, pp. 37-39. Segundo Carlos Salles, a proposta da instrumentalidade metodológica situa-se em um plano epistemológico, atinente à forma como se deve construir o conhecimento no direito processual, e, ao invés de partir da norma de processo, parte da análise de um campo específico da realidade jurídica e social, para, verificados os condicionantes que lhe são peculiares, determinar a melhor resposta processual para o problema estudado. No caso dos meios alternativos de solução de conflitos, ressalta este autor que a instrumentalidade metodológica poderá gerar subsídios para moldar procedimentos consensuais para a resolução de litígios. Nesse campo, há de se esperar do processualista, mais do que a simples aplicação de normas procedimentais, a capacitação para construir arranjos ou desenhos procedimentais aptos a atender às necessidades de situações de grande especificidade Ibidem, pp. 44-45

${ }^{69}$ Há também a lei modelo da Uncitral sobre mediação e conciliação comercial internacional, aprovada em 2002, e disponível em www.uncitral.org/pdf/english/texts/arbitration/ml.../03-90953_Ebook.pdf. Acesso em 20/12/2010.
} 
No Brasil, não há uma lei geral sobre mediação, mas tramita junto ao Congresso um Projeto de Lei que será tratado no item 5.1 deste trabalho. Neste Projeto (PL $\mathrm{n}^{\mathrm{o}}$ 94/2002) há a previsão de alguns princípios que devem nortear a mediação e a conciliação: os princípios da neutralidade, da autonomia da vontade, da confidencialidade, da oralidade e da informalidade.

No âmbito da regulação local, há os provimentos dos Tribunais que regulamentam os setores de conciliação e mediação no Judiciário. O CONIMA (Conselho Nacional das Instituições de Mediação e Arbitragem), por sua vez, estabelece algumas diretrizes através de modelo de regulamento para a mediação e do código de ética dos mediadores, recomendando a todas as instituições e entidades, governamentais e privadas, organizadas para o serviço da Mediação, assim como aos mediadores ad hoc, que pautem sua atuação pelo regulamento modelo e pelo código de ética.

Referido regulamento define os princípios básicos a serem observados no processo de mediação, que são: i. o caráter voluntário; ii. o poder dispositivo das partes, respeitando o princípio da autonomia da vontade, desde que não contrarie os princípios de ordem pública; iii. a complementaridade do conhecimento; iv. a credibilidade e a imparcialidade do mediador; v. a competência do mediador, obtida pela formação adequada e permanente; vi. a diligência dos procedimentos; vii. a boa fé e a lealdade das práticas aplicadas; viii. a flexibilidade, a clareza, a concisão e a simplicidade, tanto na linguagem quanto nos procedimentos, de modo que atendam à compreensão e às necessidades do mercado para o qual se voltam; ix. a possibilidade de oferecer segurança jurídica, em contraponto à perturbação e ao prejuízo que as controvérsias geram nas relações sociais; $\mathbf{x}$. a confidencialidade do processo.

Muito embora o procedimento adotado seja definido consensualmente pelas partes, o mediador tem algumas atribuições destinadas ao resguardo do processo (controle do processo). O código de ética elaborado pelo CONIMA, dentre outras questões, trata do papel do mediador frente ao processo, estabelecendo que o mediador deverá:

\footnotetext{
i. Descrever o processo da mediação para as partes;

ii. Definir, com os mediados, todos os procedimentos pertinentes ao processo;

iii. Esclarecer quanto ao sigilo;

iv. Assegurar a qualidade do processo, utilizando todas as técnicas disponíveis e capazes de levar a bom termo os objetivos da mediação;
} 
v. Zelar pelo sigilo dos procedimentos, inclusive no concernente aos cuidados a serem tomados pela equipe técnica no manuseio e arquivamento dos dados; vi. Sugerir a busca e/ou a participação de especialistas na medida em que suas presenças se façam necessárias a esclarecimentos para a manutenção da equanimidade;

vii. Interromper o processo frente a qualquer impedimento ético ou legal;

viii. Suspender ou finalizar a mediação quando concluir que sua continuação possa prejudicar qualquer dos mediados ou quando houver solicitação das partes;

ix. Fornecer às partes, por escrito, as conclusões da mediação, quando por elas solicitado.

A garantia do devido processo legal não se confunde com as etapas da mediação, que são normalmente estudadas durante a capacitação de mediadores e conciliadores, não sendo pacífico entre as Escolas de Mediação a necessidade do seguimento de fases e etapas sequenciais.

Christopher Moore entende que há movimentos contingentes, que são respostas a questões específicas, e movimentos não contingentes na mediação. Um mediador eficiente é aquele capaz de analisar e avaliar situações críticas e planejar intervenções eficazes para lidar com as causas do conflito, e há um procedimento nesta atuação ${ }^{70}$. Segundo este autor, uma vez ouvidas as partes e analisado o conflito, o mediador constrói uma hipótese: "Este conflito é causado por $a$ e provavelmente $b$, e se $a$ ou $b$ for modificado ou avaliado, as partes poderão chegar a um acordo". A hipótese deve, então, ser testada ${ }^{71}$.

Há diferentes etapas e fases percorridas pela mediação, que não se confundem com o devido processo legal mínimo, e normalmente são ajustadas pelas partes junto ao mediador, ainda que de forma não sequencial e preclusiva. São elas ${ }^{72}$ :

1. Pré-mediação: fase de preparação em que o mediador estabelece contato com as partes disputantes, são definidos os principais pontos e princípios sobre o processo de mediação, as partes escolhem o local e tempo da sessão, definem quem estará presente (partes, família, advogados), e podem expor brevemente a controvérsia e suas expectativas. Neste momento nasce a confiança das partes no processo $^{73}$.

2. Início da mediação: Trata-se do segundo momento informativo (tendo

\footnotetext{
${ }^{70}$ MOORE, Christopher W. O processo de mediação: estratégias práticas para a resolução de conflitos. Tradução Magda França Lopes, Porto Alegre: Artmed, 1998, pp. 60-61

${ }^{71}$ Ibidem, p. 64.

${ }^{72}$ Etapas de acordo com: BRAGA NETO, Adolfo; SAMPAIO, Lia Regina Castaldi. O que é mediação de conflitos. São Paulo: Brasiliense, 2007, pp. 44-59; MOORE, O processo de mediação cit., pp. 66-67.

${ }^{73}$ Dependendo do caso e das circunstâncias, pode ser assinado um termo de mediação especificando o objeto da mediação, identificando as partes, advogados e mediador, o procedimento adotado, o local e prazo para a conclusão dos trabalhos, a remuneração do mediador, dentre outras questões. O termo de mediação é mais comum nas mediações extrajudiciais, como no âmbito empresarial, e fixa os termos do contrato de prestação de serviços. Cf. BRAGA NETO, SAMPAIO, O que é mediação cit, p. 48-49.
} 
ocorrido a pré-mediação), e o mediador fala de seu papel e função durante o processo, inicia escuta ativa do problema a partir da versão de cada uma das partes, buscando conhecer as suas formas de comunicação.

3. Investigação: baseia-se na formulação de perguntas pelo mediador para conhecer melhor a relação entre as partes e o conflito (posições, interesses, motivações etc) e coletar informações. A formulação de perguntas também pode ser feita pelas partes, com a possibilidade de surgirem outras perspectivas do conflito antes não evidenciadas. Nesta fase as perguntas binárias tendem a ser substituídas por perguntas reflexivas, que evitem impasses, observando-se a comunicação entre as partes ${ }^{74}$.

4. Agenda: as partes precisam concordar sobre as questões e temas a serem discutidos e analisados no processo de mediação (pauta de trabalho). Trata-se de um momento de definição de prioridades, em que as partes determinam a sequência para o tratamento das questões.

5. Criação de opções: desenvolve-se junto às partes uma consciência da necessidade de múltiplas opções. Realiza-se um brainstorming - as ideias e opções livremente apresentadas não são objeto de avaliação nem de tomadas de decisão neste primeiro momento.

6. Avaliação das opções: avalia-se neste momento como os interesses podem ser satisfeitos pelas opções disponíveis, e os custos e benefícios das opções. As opções são avaliadas pelas partes ou pelo mediador, se ele tiver um papel avaliativo do conflito. Há uma preferência pela escolha de critérios objetivos para esta avaliação.

7. Escolha das opções: a escolha e priorização são realizadas pelas partes.

8. Soluções: com eventual elaboração de acordo (título executivo extrajudicial ou, uma vez homologado pelo juiz, título executivo judicial). As soluções podem ser parciais ou totais.

\subsection{Justiça do Processo e Justiça do Resultado}

A busca das partes por satisfação se dá não apenas em relação aos resultados da demanda, mas também em relação ao processo pelo qual eles são gerados. Trata-se da distinção entre a justiça do processo e a justiça do resultado, que envolve diferentes níveis de percepção, controle e satisfação das partes.

Enquanto na mediação é possível que as partes definam e controlem o procedimento, no processo judicial, por sua vez, o procedimento vem estabelecido em lei e não está sujeito a adaptações ${ }^{75}$.

\footnotetext{
${ }^{74}$ Algumas técnicas podem ser aplicadas quanto às formas de questionamento: perguntas que ampliem o foco das partes, que façam as partes refletirem sobre a sua relação, com reformulação ou paráfrase, utilização de pausas técnicas, resumo do problema ou de até onde se chegou em alguns momentos, dentre outras. As sessões de mediação com as partes podem ser conjuntas ou separadas. Sendo separadas (caucus), deve ser mantida a confidencialidade do que foi dito ao mediador.

${ }^{75}$ Este foi um dos pontos polêmicos enfrentados pelo Projeto de Novo Código de Processo Civil. O projeto original conferia liberdade ao juiz para adaptar os procedimentos, adequando as fases e atos processuais às especificidades do conflito, respeitado o contraditório e a ampla defesa (art. 107). Mas o substitutivo do Projeto de Lei apresentado no Senado modificou este dispositivo e manteve a possibilidade de alterar os
} 
Sobre a satisfação com o processo, pesquisa realizada no Programa de Mediação Forense do TJDFT constatou que entre as partes que não alcançaram acordo na mediação, $85 \%$ dos entrevistados acreditam que o processo do qual participaram os ajudarão a melhor resolver questões semelhantes no futuro. Entre as partes que transacionaram, todas responderam acreditar que o processo do qual participaram irá ajudá-las a melhor resolver semelhantes questões futuras ${ }^{76}$.

A satisfação com o processo é mais difícil de ser atestada por dados estatísticos do que a satisfação com o resultado ou acordo obtido, pois decorre de percepção (subjetiva) do jurisdicionado de que o procedimento foi justo.

Comparando a justiça processual e a substancial (procedural justice vs. substantial justice), Nancy Welsh considera que a percepção dos litigantes sobre a justiça processual afeta o julgamento e a aquiescência em relação ao resultado substancial alcançado, a crença na legitimidade da instituição e em seu procedimento. Segundo esta autora, os litigantes buscam e precisam ter a oportunidade de contar suas histórias e controlar a forma pela qual o fazem; eles querem e precisam sentir que o mediador considera a história contada e está tentando ser justo; os litigantes querem e precisam sentir que foram tratados com dignidade e respeito ${ }^{77}$. Em outras palavras, a justiça do processo depende da oportunidade conferida às partes de expressarem seus pontos de vista e da garantia de que as suas vozes serão ouvidas e consideradas por alguém envolvido no processo decisório, ainda que apenas de forma a facilitar a comunicação entre elas, como é o caso do mediador $^{78}$.

Esta mesma autora também analisa a justiça processual que deve ser aplicada nos programas de mediação anexos às Cortes:

procedimentos apenas em dois momentos: para mudar a ordem de apresentação de provas e para dilatar prazos.

${ }^{76}$ Dado citado no Manual de Mediação Judicial, em introdução sobre a implantação de uma política pública na área de mediação judicial, por Rogério Favreto. BRASIL. Ministério da Justiça. Secretaria de Reforma do Judiciário. Manual de Mediação Judicial. AZEVEDO, Andre Gomma de (Org.). Brasília: 2009. Disponível em www.mj.gov.br. Acesso em 20/12/2010.

77 Tradução livre. No original: The disputants' perceptions of this justice affect their judgment and compliance about the substantial outcomes and their faith in the legitimacy of the institution that offered the procedure. The disputants want and need the opportunity to tell their story and control the telling of that story; disputants want and need to feel that the mediator has considered their story and is trying to be fair; and disputants want and need to feel that they have been treated with dignity and respect. Cf. WELSH, Nancy A. Making deals in Court-Connected cit, p. 818.

${ }^{78}$ Cf. WELSH, MCADOO, Look before you leap cit, p. 405. 
O que a justiça tem a ver com a forma através da qual ocorre a mediação nos programas anexos às Cortes? Simplesmente, quando as Cortes ativamente arcam com os custos ou mesmo requerem que os litigantes utilizem a mediação para resolver suas disputas, assumem o compromisso de uma determinação justa, que passa por considerações sobre a justiça processual. De fato, as regras de processo civil - e mais amplamente, os contorno do devido processo legal - representam o resultado de uma série de lutas para garantir que os litigantes sejam suficientemente ouvidos, que os seus requerimentos e argumentos sejam suficientemente considerados, e que algo que aparente ser justo esteja sendo feito para resolver suas questões legais. Então, dentro do contexto das Cortes, o processo da mediação deve ser considerado e analisado tendo com padrão a justiça processual $^{79}$.

A distinção entre justiça do processo e justiça do resultado tem sido objeto de pesquisas que focam na perspectiva das partes envolvidas. São consideradas duas questões gerais sobre como os litigantes avaliam suas experiências no Judiciário: uma relacionada aos resultados obtidos (outcome-related factors), como em relação aos valores contemplados no acordo ou decisão, custos e tempo despendidos, e outra relativa ao processo de solução de conflitos (process-related factors), como a percepção do litigante sobre a possibilidade de controle, participação, tratamento com respeito, etc

A reação dos litigantes em relação aos vários processos de solução de conflitos tem sido por muito tempo uma preocupação no estudo da teoria de Law and Society (vide, por exemplo, Abel, 1974; Felstiner, 1974; Gluckman, 1969; Gulliver, 1979; Nader, 1969; Nader and Todd, 1978), mas até meados de 1970 as avaliações dos litigantes eram consideradas em termos gerais. Na última década e meia, todavia, pesquisadores começaram a distinguir entre a satisfação dos litigantes com os resultados e o seu julgamento sobre a justiça do processo. A distinção entre o julgamento da justiça do processo e a satisfação com o resultado apareceu em boa parte no trabalho de Thibaut and Walker $(1975,1978)$, que mostrou que o processo pode ser julgado justo mesmo quando gera resultados insatisfatórios ${ }^{80}$.

\footnotetext{
79 Tradução livre. No original: What does justice have to do with dealmaking in court-connected mediation? Simply, when the courts actively sponsor and even require litigants to use the third party process of mediation to resolve their disputes, the courts' commitment to a just determination necessarily implicates procedural justice considerations. Indeed, the rules of civil procedure - and, more broadly, the current state of the law regarding the requirements of due process - represent the result of countless struggles to ensure that deserving litigants are sufficiently heard, that their presentations and arguments are sufficiently considered, and that something that looks like justice is being done to resolve their legal actions. Thus, within the context of the courts, the third party process of mediation should and must be judged against the standard of procedural justice. Cf. WELSH, Making deals in Court-Connected cit, pp. 859-860.

${ }^{80}$ Tradução livre. No original: Disputants' reactions to various dispute processing procedures have long been a topic of concern in the study of law and society (e.g., Abel, 1974; Felstiner, 1974; Gluckman, 1969; Gulliver, 1979; Nader, 1969; Nader and Todd, 1978), but until the mid-1970s, disputants' evaluations were thought of in general, undifferentiated terms. Over the past decade and a half, however, researchers have begun to distinguish between disputants' satisfaction with outcomes and their judgments of the fairness of procedures. The distinction between judgments of procedural fairness and satisfaction with outcomes arose in large part from the work of Thibaut and Walker (1975, 1978), which showed in laboratory settings that a procedure can be judged fair even when it yields unsatisfactory outcomes. Cf. EBENER et al., In the eye of the beholder cit, pp. 954-955.
} 
O desenho institucional dos programas de mediação, suas escolhas, o procedimento adotado e os papéis assumidos pelos atores envolvidos são questões que influenciam a percepção sobre a justiça do processo. Nesse sentido, são três as questões que McAdoo, Welsh e Wissler analisam em sua pesquisa sobre a institucionalização da mediação: i. como o desenho dos programas afeta o sucesso da institucionalização da mediação? ii. de que forma as escolhas do desenho afetam a probabilidade de se chegar a um acordo nos casos? iii. quais escolhas do desenho afetam a percepção dos litigantes da justiça processual provida pelo programa de mediação anexo à corte ${ }^{81}$

É interessante notar que a pesquisa realizada por estes autores apontou, por exemplo, que enquanto o fato de a mediação ser obrigatória não afeta a percepção da justiça do processo, a ausência das partes nas sessões de mediação impacta negativamente nesta percepção. A partir dessa e de outras conclusões obtidas com base nos dados coletados, McAdoo, Welsh e Wissler apresentam conselhos e recomendações aos designers dos programas para o momento de fazerem escolhas que influam positivamente na institucionalização da mediação e na percepção da justiça do processo:

Para maximizar o uso dos programas de mediação anexos às Cortes: - persuadir o Judiciário e as Associações de Advogados a desenvolverem um programa que se adapte à cultura jurídica local;

- obter auxílio contínuo dos juízes no encaminhamento de casos aos programas;

- tornar o uso da mediação obrigatório se uma das partes o solicitar, ou requerer que os advogados considerem a mediação no início da demanda judicial.

Para aumentar a percepção dos litigantes de que o programa proporciona justiça processual:

- requerer que os litigantes estejam presentes na sessão e convidá-los, juntamente com os seus advogados, a participarem ativamente da mesma;

- determinar que os advogados adotem uma abordagem cooperativa e preparem os clientes para a mediação;

- restringir as intervenções do mediador que sejam extremamente avaliativas, como recomendações para um acordo específico ${ }^{82}$.

\footnotetext{
${ }^{81}$ Tradução livre. No original: $i$. How does program design affect the success of the institutionalization of mediation? ii. In what ways to design choices affect the likelihood of achieving settlement of cases? iii. Which program design choices affect litigants' perception of the procedural justice provided by courtconnected mediation? Cf. MCADOO, Bobbi; WELSH, Nancy A; WISSLER, Roselle. Institutionalization: What do empirical studies tell us about Court Mediation? Dispute Resolution Magazine, vol. 2, 2003, p. 8. Em outro artigo, esses mesmos autores consideram empiricamente as perspectivas dos juízes, das partes e dos advogados para avaliar o sucesso dos programa de mediação anexos às Cortes, com base em três parâmetros: substantive justice, procedural justice e efficient justice in an appropriate forum. Cf. WELSH, MCADOO, Look before you leap cit, pp. 404-425.

${ }^{82}$ MCADOO, WELSH, WISSLER, Institutionalization cit, p. 10.
} 


\subsection{Publicização da mediação ou privatização do processo judicial?}

É recíproca a influência que a mediação e o processo judicial exercem um sobre o outro. A interação entre ambos se dá a partir de algumas tensões como as de se regulamentar e processualizar mais a mediação no âmbito do Judiciário, e de simplificar e flexibilizar mais o processo judicial, quando em contato com a mediação.

Isso representaria o predomínio da privatização ou da publicização do processo? Seria o triunfo ou o declínio da adjudicação? São questionamentos que Judith Resnik levanta para responder com base no desenvolvimento de uma terceira via, um terceiro modelo processual, que não deixaria de representar um marco do declínio da $\operatorname{adjudicação~}^{83}$.

Nessa relação entre os aspectos privados e contratuais da mediação e os aspectos públicos do processo judicial, surgiria um terceiro modelo processual para dar conta da mediação no Judiciário. Segundo Resnik, este modelo funde aspectos públicos e privados (aspects of privately-based dispute resolution with the public processes). Nos últimos quarenta anos, o Judiciário teria se apropriado de modelos privados de solução de disputas e feito com que as partes que o acessam, mesmo que não possuam relação continuada, tenham que utilizar estes mecanismos que ainda permanecem privados, mas cujo processo é regulado pelo Estado e não mais pelo contrato entre as partes ${ }^{84}$.

Segundo Barbosa Moreira, no caso dos meios extrajudiciais de solução de conflitos, deve prevalecer a publicização destes meios sobre a privatização do processo e da Justiça estatal. Nas palavras deste autor, "falar em privatização do processo é uma expressão, nalguns casos, inadequada; noutros, falsa; em todos, perigosa" ${ }^{\text {" } 5}$. Esta posição vai ao encontro do sustentado por Reuben no item acima, ao defender que os meios alternativos de solução de conflitos são influenciados pela ação estatal e submetem-se ao

\footnotetext{
${ }^{83}$ RESNIK, Judith. For Owen M. Fiss: some reflections on the triumph and the death of adjudication. University of Miami Law Review, vol. 58, 2003, p. 191.

${ }^{84}$ Ibidem, p. 191.

${ }^{85}$ Barbosa Moreira, José Carlos, Privatização do Processo cit., p. 17.
} 
devido processo legal mínimo, com a publicização dos meios alternativos suplantando a privatização do processo judicial. Trata-se de teoria unitária de uma justiça civil pública ${ }^{86}$.

A pesquisa empírica realizada neste trabalho tem em seu cenário esses dois movimentos, de publicização e privatização, no Brasil e nos EUA, considerando as novas formas de participação social na administração na Justiça ${ }^{87}$ e os diferentes papéis dos atores envolvidos: juízes, advogados, mediadores, partes, e Judiciário.

\subsection{Distinções entre os meios autocompositivos: mediação, conciliação e negociação}

Muito embora a distinção entre a mediação e a conciliação não tenha efeitos práticos para este trabalho - que trata da institucionalização dos meios autocompositivos no Judiciário - é válido ressaltar que há importantes diferenças a serem consideradas entre a mediação, a conciliação e a negociação. Entre as duas primeiras e a negociação há uma diferença formal consistente na presença do terceiro imparcial (mediador ou conciliador), pois sendo a negociação bilateral há apenas uma relação entre as partes para a produção de um acordo. Trata-se da diferença entre a autocomposição direta (negociação) e a assistida (mediação e conciliação).

Porém, eventualmente a negociação pode também contar com a figura de um terceiro (negociação assistida), e as distinções mais substanciais recaem sobre a forma de atuação e capacitação deste terceiro, o tipo de conflito e a relação entre as partes, que influem diretamente nos objetivos das técnicas autocompositivas.

\footnotetext{
${ }^{86}$ REUBEN, Constitutional Gravity: a Unitary Theory cit, pp. 952-954.

${ }^{87}$ Ada Pellegrini ressalta que a cultura da conciliação, nos países em desenvolvimento, tem como um dos seus importantes desdobramentos a institucionalização de novas formas de participação na administração na Justiça, além da gestão racional dos interesses públicos e privados, e também de assumir relevante papel promocional de conscientização política. GRINOVER, Ada Pellegrini. Os Fundamentos da Justiça Conciliativa. In: GRINOVER, Ada Pellegrini; WATANABE, Kazuo; LAGRASTA NETO, Caetano (Org.). Mediação e gerenciamento do processo: revolução na prestação jurisdicional e guia prático para a instalação do setor de conciliação e mediação. São Paulo: Atlas, 2008, p.2.
} 
Quanto à atuação do terceiro, ela pode ser mais ou menos ativa, facilitadora ou avaliativa $^{88}$ das possibilidades de acordo, situando-se os conciliadores entre aqueles mais ativos e diretivos da sessão, e que podem inclusive propor ideias de acordo às partes. $\mathrm{O}$ tipo de conflito e a relação continuada entre as partes também são elementos importantes na definição da técnica compositiva, pois a mediação tende a trabalhar mais profundamente as facetas do conflito e os interesses das partes que estão por trás das disputas, inclusive no âmbito emocional, para manter a relação entre elas, enquanto a conciliação tende a se dar no âmbito da disputa, muitas vezes limitada ao objeto do processo, quando na esfera judicial. Na conciliação, o procedimento é mais simples e a sessão mais rápida, pois normalmente não se entra no mérito do caso, que é direcionado ao acordo, enquanto na mediação o acordo não é a meta, mas apenas um dos resultados possíveis $^{89}$.

A respeito da postura do terceiro imparcial frente à autonomia das partes, o conciliador pode assumir um lugar de poder, pois embora ele não tenha autoridade para impor uma decisão às partes, as técnicas de que se utiliza buscam conduzir as partes à realização do acordo. Esta situação é especialmente comum nas conciliações institucionais, como as que ocorrem no Judiciário, tanto nas sessões de conciliação dos juizados especiais quanto nas audiências de conciliação e julgamento presididas pelo juiz ${ }^{90}$. O conciliador

\footnotetext{
${ }^{88}$ Segundo Wayne Brazil, quanto mais avaliativa e menos imparcial for a postura do mediador, maior é o risco de as partes litigarem e competirem para tentar "ganhar" a causa diante do mediador. Nas palavras deste autor: Our concern about the possible "litigization" of mediation has additional implications for courtsponsored ADR program design. As suggested above it's likely that the risk of "litigization" increases with the extent to which the ADR proceedings are explicitly "evaluative". In an ADR process that will include an express assessment of the merits of the parties' positions by the neutral, the lawyers and their clients have a substantial incentive to compete to try to "win" the neutral's mind. Cf. BRAZIL, Waine. Continuing the Conversation about the current status and the future of ADR: a view from the Courts. Journal of Dispute Resolution, vol. 11, 2000, p. 33.

${ }^{89}$ A conciliação não requer relacionamento significativo no passado ou contínuo entre as partes no futuro, que preferem buscar um acordo de forma imediata para pôr fim à controvérsia ou ao processo judicial: aplica-se ao caso de acidente de veículos e relações de consumo em que as partes não possuem vínculos afetivos, profissionais ou sociais e não conviveram e não irão conviver após aquele ato, somente necessitando de um terceiro que as ajude a refletir qual seria a melhor solução para a controvérsia, evitando os desgastes de uma batalha judicial. O objetivo maior da conciliação seria a composição das partes para pôr fim à demanda, quer judicial, quer extrajudicial. Cf. BRAGA, Reflexões sobre a Conciliação e a Mediação cit., pp. 489/491-492. Nesse mesmo sentido, Juan Vezzulla ressalta que a grande diferença ao escolher entre a conciliação e a mediação reside na existência ou não de relacionamento entre as partes (família, comerciantes com um longo trabalho conjunto, relações laborais, relações de vizinhança, relações contratuais em que as partes desejam manter o relacionamento). A sua existência exige um trabalho de mediação e a sua ausência ou a existência de simples relacionamentos circunstanciais sem desejo de continuação ou aprofundamento (acidentes de aviação, compra e venda de objetos, agressões entre desconhecidos) permitem a aplicação rápida e econômica da conciliação, que trata o conflito de forma menos aprofundada do que a mediação. Cf. VEZULLA, Mediação cit, p. 83.

${ }^{90}$ COSTA, Cartografia dos métodos cit., p. 181.
} 
assume um papel na sessão de conciliação diferente daquele assumido pelo mediador na sessão de mediação, onde o protagonismo recai sobre as partes e em sua responsabilidade para decidir o conflito.

Tanto a mediação quanto a conciliação, quando incidentais ao processo judicial, tem em seu cenário o poder-dever do juiz de decidir o litígio, que está suspenso enquanto as formas autocompositivas atuam no conflito e o poder de decisão cabe às partes, mas que pode ser retomado pelo juiz caso não haja uma solução consensual entre as partes. No caso da institucionalização dos meios autocompositivos no Judiciário, uma das questões que é abordada a seguir, inclusive na pesquisa empírica, é se o terceiro (conciliador e mediador) está mais próximo das partes ou do juiz, na medida em que o procedimento da mediação é em parte influenciado pelo Judiciário.

A pesquisa empírica realizada neste trabalho analisou tanto programas de mediação quanto de conciliação, não sendo o seu objetivo firmar conceitualmente uma distinção entre ambos. Esta diferença está mais presente em países de língua latina ${ }^{91}$, não se observando a mesma preocupação em distinguir estas técnicas autocompositivas nos países de common law, muito embora as diferenças entre os tipos de mediação e postura do mediador (transformativa, avaliativa e facilitativa) reflitam preocupações semelhantes às que estão subjacentes à distinção entre mediação e conciliação. Muitos programas denominados nos EUA de mediação seriam tidos no Brasil como programas de conciliação.

Em termos práticos, observou-se no âmbito judicial que quanto maior é o volume de demandas submetidas ao programa, maior é a probabilidade de o programa ser de conciliação e não de mediação, pois este último tende a trabalhar o conflito de forma mais profunda, com base nos interesses e nas relações continuadas entre as partes, o que exige mais tempo destinado às sessões e ao desenrolar do processo de mediação. No caso da conciliação, algumas sessões observadas foram marcadas em um intervalo de 15-20 minutos, para casos que não envolviam relação continuada entre as partes e que foram direcionados a acordo, sem maior preocupação das partes, dos advogados e dos conciliadores em relação à justiça do processo e à justiça do resultado.

\footnotetext{
${ }^{91}$ Cf. BRAGA, SAMPAIO. O que é mediação cit., p.17.
} 
O item seguinte sobre Escolas de Mediação é uma forma de didaticamente expor essas diferentes premissas e definições que podem ser adotadas tanto no âmbito teórico quanto no âmbito prático da mediação. Não há um consenso quanto aos objetivos da mediação, e as Escolas representam diferentes vertentes, inclusive ideológicas, com um caráter descritivo e prescritivo de como a mediação deve ser realizada ${ }^{92}$. Nenhuma é mais correta do que a outra e é comum ouvir-se falar na possibilidade de um mix e combinação entre elas, utilizando variadas ferramentas da mediação, de acordo com a demanda do caso concreto $^{93}$.

Bush e Folger veem problemas nesta combinação. Consideram que ainda que diferentes teorias sobre o conflito e mediação possam ser válidas, não seria possível combiná-las ou integrá-las de forma coerente, nem no nível teórico nem no prático, em face dos diferentes objetivos e premissas nos quais se baseiam. Apenas uma delas poderia ser aplicada, coerentemente, por vez ${ }^{94}$. Assim, não seria possível haver uma mediação transformativa e ao mesmo tempo voltada ao acordo (settlement-transformative version of mediation). Os valores e ideologia que estão por trás de cada uma são diferentes e incompatíveis, ora voltados ao controle do conflito e à sua percepção como algo negativo, ora direcionados à sua transformação e à oportunidade de melhorar a relação entre as partes. Há por trás disso diferentes visões sobre a sociedade e os conflitos, que podem ser vistos como algo positivo ou negativo, e isso se reflete diretamente nos objetivos de

\footnotetext{
92 Bush e Folger fazem esta distinção das Escolas a partir de quatro diferentes estórias do processo de mediação: the satisfaction story (considera a mediação uma ferramenta para satisfazer os interesses das partes e reduzir a morosidade e volume de processos nas cortes, promovendo justiça de mais qualidade aos casos individuais); the social justice story (mediação como um veículo para que as partes e comunidades melhor se organizem em torno de interesses comuns e obtenham um tratamento socialmente mais justo), the opression story (mediação como uma forma de controle e opressão social) e the transformative story (mediação como uma forma de transformar qualitativamente a interação entre as partes). BUSH, Robert Baruch, FOLGER, Joseph. The promise of mediation: the transformative approach to conflict. San Francisco: Jossey Bass, 2005, pp. 8-9.

93 Nancy Welsh, com base em pesquisa empírica sobre mediação escolar que levou em consideração a perspectiva das partes mediadas, critica a rígida distinção entre a mediação transformativa, facilitativa e avaliativa, que se torna secundária diante das questões centrais a serem buscadas na mediação, voltadas à justiça do processo e do resultado: The voices of these disputants suggest that rigid distinctions between transformative, facilitative, and evaluative interventions are much less important than the answers to the following questions: Were the mediators' interventions preceded by and grounded in a procedurally just process? Did the mediators' interventions assist the disputants in making progress toward resolution of the issues they had identified and using norms they perceived as legitimate? Cf. WELSH, Nancy. Stepping back through the looking glass: real conversation with real disputants about institutionalized mediation and its value. Ohio State Journal on Dispute Resolution, vo. 19, 2004, p. 671.
}

${ }^{94}$ BUSH, FOLGER. The promise of mediation cit., p.45. 
controle e neutralização dos seus efeitos ou no objetivo de trazê-los à tona para propiciar às partes maior senso e percepção de si e do outro ${ }^{95}$.

De todo modo, é certo que cabe às partes decidir o modelo a seguir, e o papel do mediador é qualificar esta escolha ao informá-las e deixá-las conscientes sobre os objetivos, premissas e práticas de cada modelo. A seguir, uma breve descrição de cada Escola de Mediação.

\subsection{Escolas de mediação - "receitas e não seitas" 96}

\section{a) Negociação assistida baseada em princípios (problem-solving)}

Segundo esta Escola, desenvolvida no Programa de Negociação de Harvard (The Program on Negotiation at Harvard Law School - PON), a mediação é uma negociação facilitada ou assistida, sendo possível dois tipos de abordagens: a adversarial e a de solução de problemas (problem-solving). A abordagem adversarial considera que a negociação é focalizada em recurso limitado - como o dinheiro - e que as partes decidirão se o dividem e como o fazem (os objetivos das partes entram em conflito - o que uma ganha, a outra tem que perder). A abordagem não adversarial (problem solving), em contraste, procura revelar e compor os interesses subjacentes das partes, ou seja, os interesses que motivam suas posições ${ }^{97}$.

Trata-se da diferença entre os modelos distributivo e integrativo de negociação, que é revelada através dos célebres exemplos da divisão do bolo e da fruta. O modelo distributivo é exposto quando na divisão do bolo entre os dois filhos, o pai diz: um corta e

\footnotetext{
${ }^{95}$ Ibidem, pp. 231-232/239-258.

96 A primeira vez que esta autora ouviu a expressão (receitas e não seitas) relacionada às Escolas de Mediação foi em disciplina sobre Mediação em Conflitos de Justiça, Cultura da Paz e Promoção dos Direitos Humanos II, na Pós Graduação da Faculdade de Direito da Universidade de São Paulo (USP), em aula ministrada pelo Professor Antônio Rodrigues de Freitas Jr.

97 RISKIN, Leonard L. Understanding mediators' orientations, strategies, and techniques: a grid for the perplexed. Harvard Negotiation Law Review, vol. 7, 1996, pp. 13-14
} 
o outro escolhe a primeira fatia. As partes precisam nesse caso distribuir os ganhos e perdas, tendendo a buscar um meio termo.

O modelo integrativo de negociação, por outro lado, é exemplificado quando duas pessoas estão brigando pela mesma fruta, mas enquanto uma quer a casca para fazer um bolo, a outra quer o interior da fruta para fazer um suco. Neste caso, se a fruta fosse dividida em duas partes (modelo distributivo), as duas pessoas perderiam, mas se fossem levados em conta os seus interesses, ambas poderiam sair totalmente satisfeitas.

Este modelo integrativo foi desenvolvido no Programa de Negociação de Harvard, onde Roger Fisher e Willian Ury foram os precursores em sugerir uma via alternativa à polarização entre hard e soft positional bargaining. Trata-se da negociação baseada em princípios, que gerou o livro Getting to Yes: negotiating agreement without giving in.

No Projeto de Negociação de Harvard nós desenvolvemos uma alternativa à barganha baseada em posições: um método de negociação explicitamente desenhado para produzir resultados amigáveis e eficientes. Este método, denominado negociação baseada em princípios ou negociação baseada no mérito, pode se resumir em quatro pontos centrais ${ }^{98}$.

As quatro orientações centrais que formam este novo método de solução de conflitos são: i. (pessoa) separar as pessoas do problema. ii. (interesses) focalizar nos interesses em jogo, não na posição das partes; iii. (opções) inventar opções de ganho mútuo; iv. (critérios) insistir em critérios objetivos ${ }^{99}$.

Estas orientações revelaram-se muito úteis, tendo surgido diferentes conceituações e tipos de mediação a partir delas. Buscando sistematizar e facilitar o diálogo entre os vários tipos de mediação, Leonard Riskin desenvolveu um sistema a partir de duas variáveis: i. definição do nível de amplitude do problema (restrito ou amplo); ii. forma de atuação do mediador (avaliadora ou facilitadora). Seu objetivo foi criar uma classificação

\footnotetext{
98 Tradução livre. No original: At the Harvard Negotiation project we have been developing and alternative to positional bargaining: a method of negotiation explicitly designed to produce wise outcomes efficiently and amicably. This method, called principled negotiation or negotiation on the merits can be boiled down to four basic points. Cf. FISHER, Roger; URY, William; PATTON, Bruce. Getting to Yes: negotiating agreement without giving in. 2nd Ed., United States: Pinguin Books, 1991, p. 10

${ }^{99}$ Um passo a passo sobre cada uma destas orientações pode ser conferido em FISHER, URY, PATTON. Getting to Yes cit., pp. 15-94.
} 
baseada em categorias claras e que descrevessem as orientações, estratégias e técnicas utilizadas em variados contextos de mediação ${ }^{100}$.

A classificação da mediação, segundo Riskin, depende destas duas variáveis, que correspondem aos dois eixos cartesianos do quadro que o autor montou para analisar as técnicas e orientações do mediador: i. (vertical) papel do mediador - avaliador ou facilitador e ii. (horizontal) definição do problema - ampla ou restrita:

Papel do mediador: AVALIADOR

\begin{tabular}{c|c|c|}
\cline { 2 - 3 } $\begin{array}{c}\text { Definição do } \\
\text { problema: RESTRITA }\end{array}$ & $\begin{array}{c}\text { AVALIADOR } \\
\text { RESTRITO }\end{array}$ & $\begin{array}{c}\text { AVALIADOR } \\
\text { AMPLO }\end{array}$ \\
\cline { 2 - 3 } & $\begin{array}{c}\text { FACILITADOR } \\
\text { RESTRITO } \\
\text { problema: AMPLA }\end{array}$ & $\begin{array}{c}\text { FACILITÃõo do } \\
\text { AMPLO }\end{array}$ \\
\hline
\end{tabular}

Papel do mediador: FACILITADOR

São quatro tipos ideais de mediador (avaliador restrito, avaliador amplo, facilitador restrito, facilitador amplo), não havendo uma divisão rígida entre eles, pois normalmente o mediador atua segundo uma orientação predominante dentre os quatro tipos sugeridos ${ }^{101}$.

Esse quadro com eixos cartesianos tem um caráter estático que não contempla toda e qualquer postura dos mediadores. Mas, apesar das limitações, reconhece Riskin a possibilidade de o quadro garantir uma comunicação razoavelmente clara sobre o que pode acontecer em uma mediação, ajudando as partes a decidir se empregam a mediação ou outro meio de solução de conflito ${ }^{102}$.

O quadro pode também auxiliar as pessoas a entenderem a mediação e tomarem boas decisões sobre o tipo de processo que querem que seja utilizado, bem como sobre a seleção do mediador ideal para determinado caso. Além disso, mediadores individuais podem usar o gráfico para refletir sobre o seu próprio trabalho, entendendo que cada abordagem

\footnotetext{
${ }^{100}$ RISKIN, Understanding mediators' orientations cit., passim.

${ }^{101}$ Ibidem, p. 35.

${ }^{102}$ Ibidem, pp. 38-40.
} 
carrega potenciais vantagens e desvantagens ${ }^{103}$.

A principal crítica que surge em relação a esta classificação de Riskin, e ao modelo de mediação de Harvard, é referente à sua orientação acordista - pois a mediação é direcionada a por fim ao conflito através do acordo. Para os críticos que compõem as demais Escolas, a mediação deveria ser centrada no conflito, e não no acordo.

\section{b) Mediação transformativa}

Segundo esta Escola, os conflitos devem ser vistos não como um problema, mas como uma oportunidade para transformações das partes, tanto no sentido de autoconhecimento, como no de reconhecimento da importância do outro.

A mediação transformativa tem foco mais no processo do que no resultado. Para Luiz Warat, o objetivo desta mediação não seria o acordo, mas a transformação das pessoas e seus sentimentos, única forma de transformar e redimensionar os conflitos. Os conflitos nunca desaparecem, apenas se transformam, e o papel do mediador é ajudar as partes para que olhem ao outro e a si mesmas, sem considerar o conflito como algo exterior $^{104}$.

Nesse sentido, Robert Bush e Joseph Folger tratam da mediação transformativa sob a ótica do empoderamento das partes (empowerment dimension) e do reconhecimento do problema do outro (recognition dimension), com foco na capacidade de transformar qualitativamente a interação conflitual de uma perspectiva negativa e destrutiva para uma perspectiva positiva e construtiva, o que deixaria os indivíduos mais confiantes em si e ao mesmo tempo mais abertos a perceber o outro, gerando uma transformação individual e social das relações ${ }^{105}$.

\footnotetext{
${ }^{103}$ RISKIN, Understanding mediators' orientations cit., pp. 38-40.

${ }^{104}$ WARAT, Luis Alberto. O ofício do mediador, v. 1. Florianópolis: Habitus, 2001, p.31.

${ }^{105}$ BUSH, FOLGER. The promise of mediation cit., pp. 13-14.
} 
As pessoas aprendem a viver em um mundo onde o conflito é inevitável. O empoderamento gera a percepção pelos indivíduos do seu valor e capacidade de tomar suas próprias decisões para lidar com problemas, enquanto o reconhecimento evoca nos indivíduos a sensibilidade para conhecer a situação e a visão do outro. A conexão relacional e a capacidade de transformar a interação das pessoas em relação ao conflito são elementos centrais da mediação transformativa ${ }^{106}$.

Luiz Warat vê as bases desta transformação em uma perspectiva mais ampla: o mediador seria um psicoterapeuta de vínculos conflitivos, devendo ajudar as partes para que sintam seus sentimentos e construam vínculos, de forma autônoma e holística, a partir de sua identidade e sensibilidade. Trata-se de uma linha de trabalho imprescindível para os trabalhadores da saúde, da educação, do direito, da ecologia, do trabalho comunitário, ou de psicoterapias familiares ${ }^{107}$. O mediador ajuda as partes a reconstruírem simbolicamente a relação conflituosa. ${ }^{108}$

Nas palavras deste autor, "estamos falando de uma possibilidade de transformar o conflito e de nos transformarmos no conflito, tudo graças à possibilidade assistida de poder nos olhar a partir do olhar do outro, e colocarmo-nos no lugar do outro para entendê-lo a nós mesmos"109. Assim, "a Teoria Contradogmática do direito e da sociedade encara a mediação como uma visão de mundo, um paradigma ecológico e um critério epistêmico de sentido" " 110 É por isso que "o Ofício de Mediador seria muito mais que a procura de um novo modo de ser profissional, é a atitude que todos precisamos ter diante da vida, o ofício de viver"111.

Warat relata a experiência do Tribunal de Justiça de Santa Catarina em implementar programa de direito e de justiça cidadã, um projeto inovador de humanização da justiça que surgiu no seio institucional da magistratura. O juiz cidadão seria o juiz de

\footnotetext{
106 Ibidem, pp. 22-26/35.

${ }^{107}$ WARAT, $O$ ofício cit., pp. 49-50.

${ }^{108}$ Ibidem, p. 80.

109 Ibidem, p. 83.

110 Ibidem, p. 87. A partir do que denomina de Teoria Contradogmática, Warat fala em produção psicoterapêutica da diferença com o outro, gerando uma corrente mediadora que denomina de mediação alternativa ou terapia do reencontro, em alguns aspectos semelhantes à corrente de mediação transformativa. A mediação alternativa, um processo do coração, trata de um trabalho simbólico-psicodramatista de base semiótico-terapêutica. Ibidem, pp. 84-85.

${ }^{111}$ Ibidem, p. 68.
} 
visão holística, que substitui o tipo e os conceitos pela forma de ver que pensa como poética, e passa por um percurso de desaprendizagem do que sabe, subtraindo do campo do consciente a informação para incorporá-la no campo do inconsciente. O projeto de humanização da justiça instrumentaliza também um segundo sentido de juiz cidadão, um juiz leigo, juízes-mediadores ou simplesmente mediadores, encarregados de ajudar as pessoas em determinados tipos de vínculos conflitivos. Este projeto da justiça catarinense culmina com o estabelecimento de juizados de cidadania, onde os indivíduos possam sair do silêncio e recuperar a voz, e que deveriam funcionar dentro do que se propôs chamar Casas de Cidadania ${ }^{112}$.

O mediador deve ter em mente que toda relação humana é plena de tensões e que nem o conflito pode ser definitivamente resolvido, nem isso é desejável, pois a conflituosidade (mantida, é claro, dentro de certos limites), é requisito e não empecilho a uma convivência saudável. Por isso, a função da mediação é transformar o modo como as partes percebem os seus conflitos, de forma a criar uma solução em que as partes sejam capazes de lidar autonomamente com a conflituosidade inerente à sua relação, no presente e no futuro. ${ }^{113}$

Bush e Folger apresentam o método de mediação transformativa de uma forma um pouco diferente de Warat. Levantam alguns mitos e críticas atribuídos à mediação transformativa: i. a mediação transformativa facilita a comunicação entre as partes, mas os conflitos tendem a não ser resolvidos; ii. a mediação transformativa é útil e apropriada apenas para casos em que há relação continuada entre as partes, que prosseguem após a mediação; iii. na mediação transformativa, o mediador é passivo durante a sessão; iv. não há uma estrutura ou ordem para a sessão de mediação transformativa; v. a mediação transformativa é uma forma de terapia que vai além da prática de mediação; vi. a mediação transformativa impõe às partes uma série de valores que devem ser aceitos por elas; dentre outras críticas e mitos ${ }^{114}$

\footnotetext{
${ }^{112}$ Ibidem, p. 218, 236/238-239. Assim, a mediação transformativa é vista como uma forma de realização de autonomia, cidadania, democracia e direitos humanos. As práticas sociais de mediação configuram-se em um instrumento de exercício da cidadania na medida em que educam, facilitam e ajudam a produzir diferenças, identidades e a realizar tomadas de decisões, sem a intervenção de terceiros que decidam pelos afetados em um conflito. Ibidem, p. 88 .

${ }^{113}$ COSTA, Cartografia dos métodos cit., p. 180.

${ }^{114}$ BUSH, FOLGER, The promise of mediation cit., pp. 216-236.
} 
Os autores refutam estas críticas uma a uma, com base nos princípios da mediação transformativa e suas diferenças em relação à mediação que busca apenas a satisfação de interesses através do acordo (que denominam de Satisfaction Story of Mediation, e que equivale ao modelo de mediação da Escola de Harvard).

A mediação transformativa ajuda as partes a decidirem por elas mesmas, e a terem suas próprias vozes, com base no empoderamento de si e no reconhecimento do outro, ainda que precisem aprender a viver com o conflito e não com a sua solução (nas palavras dos autores - they may figure out a way to "live with no" even if they cannot "get to yes"). O acordo não é o único bom resultado possível. Esta é uma escolha que as partes podem ou não fazer. $^{115}$

Em qualquer situação em que a interação entre as partes importe e a qualidade desta interação possa impactar e produzir melhores resultados, mesmo que a relação não seja continuada, a mediação transformativa pode ser aplicada, influenciando na forma como as partes vão lidar com os problemas em situações futuras ${ }^{116}$. O mediador não é diretivo da relação entre as partes, mas tem um papel essencial na escuta ativa dos problemas, na percepção das oportunidades em que se possa trabalhar o reconhecimento e empoderamento das partes, contribuindo a um diálogo construtivo entre elas. Há inúmeras técnicas a serem aplicadas, sumarizando o que as partes apresentaram, parafraseando, checando o que as partes elencam como pontos centrais do conflito e o que gostariam de levar adiante, de forma que mesmo quando estão em silêncio, os mediadores não estão inativos $^{117}$.

Não há um processo rigidamente estruturado, mas isso não implica em ausência de forma no processo de mediação transformativa, que emerge a partir das conversas do mediador com as partes, na determinação da forma pela qual elas querem que a interação se dê em busca do seu empoderamento e reconhecimento do outro. O mediador deve ouvir as partes, no início da mediação, sobre os seus objetivos e convidá-las a refletir sobre o processo de mediação, quais questões serão abordadas, sobre a transição de um assunto

\footnotetext{
115 Ibidem, p. 217

116 Ibidem, p. 219

${ }^{117}$ Ibidem, pp. 221-222.
} 
para o outro, o tempo de mediação. À medida que essas decisões vão sendo tomadas, o processo vai ganhando uma forma. ${ }^{118}$

Nos EUA, em 1994, diante de uma situação de elevada litigiosidade, os Correios, um dos maiores empregradores dos EUA, adotaram um programa de mediação transformativa para os conflitos entre seus funcionários no ambiente de trabalho, e os resultados foram reveladores, não apenas com base nos acordos obtidos (settlement rate), mas também na adesão e participação das partes (participation rate). Trata-se do U.S. Postal Service REDRESS (Resolve Employment Disputes Reach Equitable Solutions Swiftly) Mediation Program, um programa inovador no ambiente corporativo.

A maior parte dos litígios nos Correios estava ligada à discriminação de empregados, e o volume de reclamações informais chegava a 30.000 por ano, muitas delas gerando longas e caras batalhas judiciais. Com o programa, os empregados que apresentassem reclamações de discriminação poderiam optar pela mediação antes de começar o processo formal de investigação interna. A presença na mediação tornou-se obrigatória para os gerentes que tivessem sido nomeados, muito embora eles fossem livres para fazer concessões ou não durante a participação do processo.

Após ser testado em algumas cidades, em 1997 o programa adquiriu status nacional, sendo as mediações realizadas por terceiros neutros. Nos primeiros 22 meses de operação, os resultados foram impressionantes: de setembro de 1998 a Junho de 2000, 17.645 disputas informais foram mediadas pelo programa REDRESS e, destas, $80 \%$ foram resolvidas. O programa também inspirou outras Agências Federais a usarem a mediação transformativa em seu ambiente de trabalho, dentre elas a Transportation Security Administration ${ }^{119}$.

\footnotetext{
118 Ibidem, p. 225.

${ }^{119}$ Robert A. Baruch Bush ajudou a montar o programa de treinamento dos 3000 mediadores contratados para atuar no programa, tendo por objetivo mudar as conversas entre empregados e supervisores de um tom destrutivo para construtivo. Ibidem, pp. 26-31/107. Mais informações estão disponíveis em www.businessofgovernment.org/pdfs/Bingham_Report.pdf . Acesso em 20/12/2010.
} 


\section{c) Mediação circular narrativa}

Esta Escola tem como foco a história e narrativa dos conflitos, considerando o contexto linguístico em que estão inseridos para criar uma circularidade relacional que possibilite a criação de um discurso convergente. A teoria da comunicação está na base deste modelo, que tem como uma de suas representantes Sara Cobb ${ }^{120}$.

Sara Cobb e Janet Rifkin ressaltam que o modelo em questão parte da premissa de que a linguagem é constitutiva e não meramente representativa da realidade, sendo as narrativas estruturas discursivas em que os conflitos são construídos e transformados ${ }^{121}$.

Nesta comunicação circular são levados em conta os elementos de expressão verbais e não verbais (corporais, gestuais), estes últimos considerados como metacomunicativos, na medida em que também qualificam o conteúdo da comunicação. Não há uma causa única que produza um determinado resultado, mas uma causalidade de tipo circular, que permanentemente se retroalimenta ${ }^{122}$.

Conforme ressalta Marinés Suares, neste modelo de mediação há uma influência forte de técnicas provenientes de outras áreas das ciências sociais, como da teoria da comunicação e da teoria dos sistemas, baseando o seu método no fomento à reflexão e aumento das diferenças, até determinado ponto, para que através delas as partes consigam se expressar e transformar. Diferentemente do modelo de Harvard - pelo qual se entende que as partes chegam à mediação com um problema a ser resolvido - o modelo circular narrativo considera que as partes chegam à mediação em uma situação de ordem, envolvidas com as suas posições, devendo ser inserido o caos na ordem, para que as diferenças e reflexões apareçam, podendo-se lograr uma nova ordem ${ }^{123}$.

\footnotetext{
${ }^{120}$ COBB, Sara, RIFKIN, Janet. Practice and Paradox: deconstructing neutrality in Mediation. Law \& Society Inquiry, vol. 16, 1991, 35-62. Sobre mediação narrativa, há também WINSLADE, John; MONK, Gerald. Narrative Mediation: A New Approach to Conflict Resolution. San Francisco, CA: Jossey-Bass, 2000.

${ }^{121}$ Ibidem, pp. 50-51.

${ }^{122}$ SUARES, Mediación cit., p. 61. Marines Suares faz uma releitura do modelo circular narrativo de Sara Cobb, revelando os desafios que se apresentam na teoria e na prática. Ibidem, pp. 207-234.

${ }^{123}$ Ibidem, p. 62.
} 
Para cada parte, a sua história é a história verdadeira, e o trabalho fundamental do mediador é construir uma história alternativa, que permita às partes verem o problema sob outros ângulos, logrando-se um acordo. Para Marinés Suares, enquanto o modelo de Harvard acabou sendo mais apropriado para a condução de conflitos na área empresarial, voltando-se ao acordo e estando mais próximo da negociação, e o modelo transformativo voltou-se para as relações continuadas e duradouras, o modelo circular narrativo estaria no meio do caminho, pois se volta tanto à mudança das relações quanto aos acordos ${ }^{124}$.

John Winslade e Gerald Monk também tratam deste modelo de mediação narrativa, diferenciando-o do modelo de Harvard (problem-solving) por não presumir que as posições assumidas pelas partes divergem de seus verdadeiros interesses, mas sim que ambos são construídos a partir de uma descrição narrativa do conflito. O movimento não é de fora para dentro, em busca dos interesses (outside-in), mas de dentro para fora (inside-out), estando o conflito relacionado à narrativa e aos discursos das partes ${ }^{125}$.

$\mathrm{O}$ processo de mediação narrativa inclui movimentos de desconstrução e construção, identificando-se o discurso dominante e o discurso alternativo como premissa para a construção de novas narrativas. O processo ao todo tem três fases: fase de engajamento das partes, de desconstrução e de reconstrução ${ }^{126}$.

Reconhecem Winslade e Monk, todavia, que mais do que uma sugestão de novas técnicas, este modelo requer um compromisso de quem o aplica com a adoção de suas premissas, filosóficas e teóricas, tendo por trás uma forma de pensar construtivista, que vê a linguagem como pré-condição do pensamento e o conflito como objeto de um ponto de vista narrativo $^{127}$

\footnotetext{
${ }^{124}$ Ibidem, p. 62-63.

${ }^{125}$ WINSLADE, MONK, Narrative Mediation cit., p. ix.

126 Os detalhes do processo de mediação narrativa, suas fases e técnicas podem ser conferidos em WINSLADE, MONK, Narrative Mediation cit., 2000, pp. 58-93. Segundo estes autores, a mediação narrativa foca nas seguintes questões: i. the privileging of stories and meanings over facts; $i$. the hearing of people's stories of conflicts as they are produced in discourse; iii. the clear separation of conflict-saturated stories from stories of respect, cooperation, understanding and peace; iv. the use of externalizing conversations to help disputants extract themselves from problem stories that have held them in thrall; $\boldsymbol{v}$. the creation of a relational context of change as a primary task of mediation in preference to the pursuit of an agreed-upon solution; vi. the selection of alternative stories for development as path-ways out of dispute. Ibidem, p. 250.

${ }^{127}$ Há diretrizes que informam o que os autores denominam de construtivismo social, estando entre elas o papel da linguagem, constitutivo do pensamento e ao mesmo tempo uma forma de ação social, e a visão narrativa do conflito, Ibidem, pp. 37- 47/ 250.
} 


\section{INSTITUCIONALIZAÇÃO DA MEDIAÇÃO NO JUDICIÁRIO}

Consideradas as bases constitutivas da mediação/conciliação, descritas no segundo capítulo desta tese, como pré-requisito para uma boa interação entre a mediação e o processo judicial, o terceiro capítulo tem como foco a institucionalização da mediação no Judiciário, quais são as razões, os riscos e as experiências que vêm sendo adotadas quer no Judiciário, quer no meio do caminho entre o comunitário e o institucional. O capítulo se encerra com a apresentação da pesquisa empírica realizada e com base na qual são desenvolvidos os capítulos seguintes, sobre a institucionalização da mediação no Judiciário Brasileiro e no Judiciário Norte-Americano.

\subsection{Por que institucionalizar a mediação?}

Quando se reflete sobre os porquês de se institucionalizar a mediação, levando-a ao Judiciário, algumas respostas são usualmente apontadas:

i. Porque o Judiciário é um lugar onde se encontram e para onde confluem os conflitos, devendo-se abrir uma porta e válvula de escape aos meios autocompositivos dentro dele $\mathrm{e}^{128}$.

\footnotetext{
${ }^{128}$ Cf. Frank Sander, idealizador do sistema de multiportas de solução de conflitos nos EUA. Sander entende que muito embora não haja uma relação necessária entre os meios de solução de conflitos e o Judiciário, como a Corte é um repositório de conflitos, haveria uma atração natural a este ambiente institucional para o processamento de casos via ADR. Assim como o ladrão vai a Banco porque é o lugar onde há dinheiro, a mediação vai ao Judiciário porque este é o lugar onde há casos e conflitos. Em suas palavras: there is not necessarily a relationship between ADR and the Court System. I think, on the other hand, it is a pretty natural relationship because courts are our main, perhaps our most important, dispute-resolution place. So, one can make a strong argument that the multi-door courthouse ought to be connected with the courts, but technically the comprehensive justice center [or multi-door courthouse] that I mentioned could be quite separate from the courts. It's a little bit like the story about Willie Sutton, the bank robber, who, when asked why he robbed banks, said, "That's where the money is." The court is where the cases are. So, it is natural to have the court as one door of the multi-door courthouse! That is the idea. But it could be that the court could be over here and the other processes [arbitration, mediation, etc.] could be over there; there is nothing inherent [in the scheme] that prevents this. Entrevista de Frank Sander concedida à Mariana Hernandez Crespo, diretora executiva da University of St. Thomas International ADR Research Network, cuja transcrição integral está disponível em http://papers.ssrn.com/sol3/papers.cfm?abstract_id=1265221. Acesso em 20/12/2010.
} 
ii. Para se viabilizar uma nova forma de acesso à justiça, através dos meios autocompositivos, entendida não apenas como acesso formal ao Judiciário.

iii. Para se reduzir a morosidade do Judiciário, atuando os meios alternativos como um dos remédios para a crise do Judiciário.

iv. Para processualizar novos conflitos (litigiosidade contida ou reprimida), uma vez que a mediação seria uma nova porta e daria visibilidade a parcelas dos conflitos antes ofuscadas pela demanda judicial.

v. Para incentivar a utilização da mediação, para que ela conte com a confiança das partes em relação ao Judiciário, em sua legitimidade, além do estabelecimento de regras sobre seu funcionamento e destinação de recursos orçamentários aos programas/setores de mediação e conciliação.

vi. Para que um papel pedagógico possa ser exercido diante dos juízes, das partes e dos advogados quanto à escolha da técnica compositiva mais adequada a cada conflito, reconhecendo-se os limites do Judiciário para processar e resolver todos os litígios e a necessidade de mudança da mentalidade litigante.

vii. Para que um papel fiscalizatório possa ser exercido pelo Judiciário, quer quanto ao procedimento, quer quanto aos acordos obtidos e que podem ser objeto de homologação judicial.

Estas respostas não são excludentes e algumas são consideradas como concausas que levam à institucionalização da mediação no Judiciário. Podem estar mais próximas dos objetivos das partes, do Judiciário ou de ambos, assim como podem implicar no aumento ou redução do número de demandas.

Por institucionalização da mediação entende-se neste trabalho a sua implementação, regulação e suporte conferidos pelo Judiciário, quer antes do processo judicial, quer incidentalmente a ele (mediação pré-processual e processual). Isso implica em sua instituição formal por alguma norma (portaria, provimento, resolução, decreto ou lei), com regras acerca de seu procedimento e funcionamento, existência de orçamento 
específico, capacitação de recursos humanos e provimento de cargos para os programas, buscando que a sua continuidade não dependa apenas da iniciativa individual de alguns atores, como do juiz no gerenciamento de processos e do Presidente do Tribunal no exercício de sua gestão e mandato ${ }^{129}$.

Isso não exclui a possibilidade de institucionalização da mediação em outros foros, como no Poder Executivo, através de iniciativas do Ministério da Justiça e de Secretarias de Justiça ${ }^{130}$, no Ministério Público, nas Defensorias Públicas, na Advocacia Geral da União (destaque neste caso para a Câmara de Conciliação e Arbitragem da Administração Federal), ou mesmo nos Centros e Câmaras de Mediação e Arbitragem, em ambiente institucional privado. Neste trabalho o foco é a institucionalização da mediação no âmbito do Judiciário, que tem sido protagonista neste movimento de apoio e incentivo aos meios autocompositivos, quer no Brasil, quer nos EUA.

Peter Adler, um dos primeiros a trabalhar com os programas anexos às Cortes nos EUA, e Diretor do Centro de Solução de conflitos no Havaí, alerta para o fato de que a institucionalização precisa considerar mais do que a mera criação e implementação de programas de mediação pelo Judiciário, mas também uma mudança de mentalidade dos juízes, advogados e partes para que eles passem a sistematicamente incluir os meios alternativos de solução de conflitos em suas rotinas profissionais. Os programas acabam a

\footnotetext{
129 Tentativas de estruturação dos centros de mediação e conciliação, criação de cartórios próprios, destinação de funcionários e juízes ao setor, com a redução e não mera cumulação com as atividades anteriormente exercidas, normatização de iniciativas e uniformização de práticas, inclusive relacionadas à seleção e capacitação dos mediadores/conciliadores, e a existência de políticas nacionais de suporte à mediação são algumas formas de tornar os meios autocompositivos mais estáveis e menos vulneráveis às prioridades e escolhas de cada juiz e Tribunal.

${ }^{130}$ No Estado de São Paulo, por exemplo, o Centro de Integração da Cidadania (CIC) é um programa da Secretaria da Justiça e da Defesa da Cidadania que visa proporcionar o acesso à Justiça, por intermédio de serviços públicos de qualidade para a população e o incentivo à cidadania comunitária, aproximando o poder público e a comunidade. Sua função é promover o exercício da cidadania por meio da participação popular e garantir formas alternativas de acesso à justiça, havendo, dentre vários serviços prestados, uma Câmara de Mediação (vide mais informações em http://www.justica.sp.gov.br/modulo.asp?modulo=52\&Cod=52 Acesso em 20/12/1010 - e HADDAD, Eneida Gonçalves de Macedo; SINHORETTO, Jacqueline; PIETROCOLLA, Luci Gati. Justiça e Segurança na periferia de São Paulo: os centros de integração da cidadania. São Paulo: IBCCRIM, 2003.). No Rio de Janeiro, por sua vez, há as Unidade de Policiamento Pacificadora (UPPs), um novo modelo de Segurança Pública e de policiamento que promove a aproximação entre a população e a polícia, aliada ao fortalecimento de políticas sociais nas comunidades. Criadas pela Secretaria de Estado de Segurança, as UPPs trabalham com os princípios da Polícia Comunitária, baseada em estratégia fundamentada na parceria entre a população e as instituições da área de segurança pública.
} 
menos que encontrem uma ampla base de suporte e sejam percebidos pelas partes como necessários e importantes ao atendimento de seus interesses. ${ }^{131}$

No Brasil, conforme ressalta Kazuo Watanabe, a formação acadêmica dos operadores do direito é ainda voltada, fundamentalmente, para a solução contenciosa e adjudicada dos conflitos por meio do processo judicial, em que é proferida uma sentença que constitui a solução imperativa dada pelo representante do Estado. É esse o modelo ensinado pelas faculdades de direito do país e é esse o modelo de profissional do direito exigido pelo mercado para as principais carreiras profissionais, como a advocacia, a magistratura, o ministério público e as procuradorias públicas. Disso nasce a chamada "cultura da sentença", que tem como consequência o aumento cada vez maior da quantidade de processos, recursos e execuções e que precisaria ser substituída pela chamada "cultura da pacificação" 132 , como um dos primeiros passos para se garantir o êxito da institucionalização da mediação no Judiciário.

Segundo Cappelletti, a ideia de meios alternativos (conciliação, mediação, arbitragem) não é nova, mas as sociedades modernas descobriram novas razões para preferir tais alternativas, e uma delas está relacionada ao fato de que o processo judicial deve ser acessível a toda a população. Esse é o preço do acesso à justiça, o preço da própria democracia e que as sociedades modernas deveriam sentir-se dispostas a (e felizes em) $\operatorname{pagar}^{133}$.

\footnotetext{
${ }^{131}$ Cf. BRAZIL, Wayne D. Institutionalizing ADR programs in Courts. In: SANDER, Frank E. A. Emerging ADR Issues in State and Federal Courts, American Bar Association, 1991, pp. 58-59. Em sentido estrito, Sander define a institucionalização como: building in, from the outset, structural support (financial and administrative) that will fully meet the needs of the program and that is not dependent on the energy and interest of any one human being or small group of human beings. Ibidem, p. 58.

${ }^{132}$ WATANABE, Cultura da sentença cit. p. 685.

133 CAPPELLETTI, Os métodos alternativos de solução de conflitos cit, p. 88. O problema, todavia, é quando a litigância está associada a poucos atores, em um contencioso de massa que contribui à morosidade sem gerar efetivo acesso à justiça a um maior segmento da população. Sobre o mapeamento de litigância repetitiva e a não correspondência entre o aumento do número de demandas e o aumento e diversificação do número de litigantes, com foco especial nas causas da litigância, há pesquisa conduzida pela DIREITO GV e contratada pelo Conselho Nacional de Justiça. Cf. CUNHA, Luciana Gross. GABBAY, Daniela Monteiro (Coord.). Diagnóstico sobre as causas de aumento das demandas judiciais cíveis, mapeamento das demandas repetitivas e propositura de soluções pré-processuais, processuais e gerenciais à morosidade da justiça. Departamento de Pesquisas Judiciárias - Conselho Nacional de Justiça. Brasília: 2010. Aguardando publicação.
} 
Ainda segundo o mencionado autor, os meios alternativos estão relacionados à terceira onda de acesso à justiça ${ }^{134}$, na qual a perspectiva dos usuários da justiça se destaca nos debates sobre acessibilidade e, por conseguinte, sobre o custo, duração, e em geral sobre os obstáculos - econômicos, culturais e sociais - que com tanta frequência se interpõem entre o cidadão que demanda justiça e o procedimento destinado a concedê$1 \mathrm{a}^{135}$.

A terceira onda do movimento pelo acesso à justiça trouxe à tona a necessidade de simplificação dos procedimentos e de alternativas de justiça. Para Cappelletti, deve haver a substituição da justiça contenciosa pelo que denomina de justiça coexistencial, baseada em formas conciliatórias que considerem a natureza continuada das relações. Em tais relações, a lide não representa outra coisa senão um momento ou sintoma de tensão que, nos limites do possível, deve ser tratado tendo em vista a preservação da relação, voltando-se ao futuro e não ao passado ${ }^{136}$.

No Brasil, o movimento de democratização do acesso à justiça teve como um de seus marcos centrais a criação dos Juizados de Pequenas Causas (Lei n $n^{0}$ 7224/84), posteriormente denominado Juizados Especiais Cíveis (Lei nº 9099/95). Na exposição de motivos da Lei $n^{\circ} 7224 / 84$, definiu-se a democratização do acesso à justiça como a

\footnotetext{
${ }^{134} \mathrm{O}$ movimento de acesso à justiça procura caminhos para superar as dificuldades ligadas a três principais obstáculos: econômico (primeira onda renovatória de acesso à justiça, que se apoiou na assistência e orientação judiciária gratuita), organizacional (segunda onda) e processual (terceira onda), esta última onda ligada aos meios alternativos de solução de conflitos. Por obstáculo processual entende Cappelletti o fato de que, em certas áreas ou espécies de litígios, o tradicional processo litigioso em juízo pode não ser o melhor caminho para se requerer a vindicação dos direitos. Cf. CAPPELLETTI, Os métodos alternativos cit., p. 83/87. Vide ainda CAPPELLETTI, Mauro. GARTH, Bryant. Acesso à Justiça, Tradução Ellen Gracie Northfleet, Porto Alegre: Fabris, 1988.

${ }^{135}$ Mauro Cappelletti considera que os esforços organizados em torno do acesso à justiça podem existir fora do circuito jurisdicional. Cf. CAPPELLETTI, Mauro. Problemas de Reforma do Processo nas Sociedades Contemporâneas, Revista Forense, n. 318, p. 121.

136 Segundo Cappelletti, estas relações continuadas são cada vez mais frequentes nas sociedades contemporâneas, nas quais assumem grande importância o que os sociólogos denominam de total institutions (instituições totais) no sentido de que, enquanto membros de várias comunidades econômicas, culturais, sociais, somos constrangidos a passar nelas grande parte da nossa vida e atividade: fábricas, repartições públicas, escolas, bairros, etc. A fuga destas instituições é impossível, ou pelo menos importaria custos extremamente pesados, como o custo psicológico do isolamento ou da transferência para outro bairro, escola ou trabalho. O êxito da justiça coexistencial dependerá, em larga medida, da autoridade social do conciliador (que difere da autoridade oficial do juiz), da autoridade moral, cultural ou política do vizinho, do amigo, dentre outros. Cf CAPPELLETTI, Problemas de Reforma cit, pp. 123-124.
} 
facilitação do acesso do cidadão à Justiça por meio da conciliação, simplicidade dos procedimentos, celeridade e economia ${ }^{137}$.

A Constituição Federal de 1988 foi também um importante marco institucional neste movimento de acesso à justiça, com realce aos papéis assumidos pelo Judiciário, Ministério Público e Defensoria Pública e, juntamente com outros importantes instrumentos legislativos como a Lei de Ação Civil Pública (1985) e o Código de Defesa do Consumidor (1990), propiciaram um maior acesso à justiça no que se refere à tutela dos interesses e direitos individuais e coletivos.

Esse movimento de democratização do acesso à justiça foi posteriormente alvo de um discurso eficientista preocupado com a segurança jurídica, previsibilidade e celeridade na prestação jurisdicional e seus impactos na economia ${ }^{138}$, que travou um combate à crise do Judiciário e colocou em pauta uma agenda de reformas (inclusive processuais) que visavam à uniformização, celeridade e previsibilidade da tutela jurisdicional. É com base nesse discurso que a crise do Judiciário incitou e foi um dos principais fundamentos para a reforma promovida pela Emenda Constitucional no 45/2004 ${ }^{139}$.

\footnotetext{
${ }^{137}$ Segundo Luciana Gross Cunha, esta definição tem a vantagem de englobar as questões apresentadas pelas diferentes perspectivas que tratam do tema de democratização do acesso à justiça: ela aborda a eliminação dos obstáculos de acesso à justiça, a necessidade de um Judiciário eficiente para a institucionalização da democracia e a possibilidade de participação da comunidade na solução dos conflitos mediante a conciliação. Em seu livro sobre Juizados Especiais, a autora busca avaliar se os juizados especiais são uma forma de democratização do acesso à justiça ou sofrem dos mesmos problemas que afetam o juízo comum. Cf. CUNHA, Luciana Gross. Juizado Especial: criação, instalação, funcionamento e a democratização do acesso à justiça. São Paulo: Saraiva, 2008, p. 13.

${ }^{138}$ Referido discurso eficientista foi formulado primordialmente por economistas, e teve como um de seus elementos centrais os custos e riscos advindos da incerteza jurisdicional de um Judiciário moroso e imprevisível quanto às decisões judiciais sobre o cumprimento dos contratos, respeito à propriedade privada, e executoriedade dos títulos de crédito. Isto impactaria nas relações econômicas, no ambiente de negócios e no mercado de crédito, com o aumento de spreads bancários, empréstimos a juros mais altos, aumento do risco dos investimentos, e escassez de crédito a longo prazo. Vide BACHA, Edmar Lisboa. Incerteza jurisdicional e crédito de longo prazo. Valor econômico, São Paulo, 15.12.2004. PINHEIRO, Armando Castelar; CABRAL, Célia. O mercado de crédito no Brasil: o papel do judiciário e de outras instutuições. Ensaios BNDES, n. 9, 1998. Disponível em www.bndes.gov.br. Acesso em 20/12/2010. FACHADA, Pedro; FIGUEIREDO, Luiz Fernando; LUNDBERG, Eduardo. Sistema Judicial e Mercado de Crédito no Brasil. In: Nota Técnica $n^{o} 35$ do Banco Central, de maio/2003. Sobre a transnacionalização da economia e o fato da política estar cedendo espaço ao mercado como instância de regulação social, tornando a autonomia decisória e a agenda política dos Estados cada vez mais vulneráveis à conjuntura internacional, vide FARIA, José Eduardo. Direitos Fundamentais e Jurisdição: o Judiciário após a globalização. Direito em debate, Ijuí, Rio Grande do Sul, ano 6, n 9, jan./jun. 1997, pp. 7-16. FARIA, José Eduardo. $O$ direito na economia globalizada. São Paulo: Malheiros, 2002, p. 23.

${ }^{139}$ Conforme Luciana Gross Cunha e Frederico de Almeida, “o texto da Reforma do Judiciário, aprovado pelos parlamentares brasileiros em 2004, depois de muita discussão e embate político e poucos consensos sobre o que se espera do Poder Judiciário, em quase nada se parecia com o projeto original enviado doze anos antes (EC 29/1992). O projeto original enviado em 1992 tinha como objetivo a construção de um sistema de justiça mais democrático enfrentando questões como a gratuidade da justiça e dos serviços
} 
Nos EUA, por sua vez, desde meados de 1970 houve um movimento de delegalização e desregulação, em reação ao formalismo legal no âmbito institucional e da cultura jurídica como um todo (hard law vs. soft law), o que garantiu incentivos à expansão da mediação comunitária - investimentos do governo federal nos Neighborhood Justice Centers, fora do Judiciário, que forneciam serviços de mediação gratuitos ou a baixo custo para o público, buscando o empoderamento das partes e o fortalecimento do acesso à justiça $^{140}$.

Muitos dos atuais programas de mediação começaram informalmente como centros de mediação comunitária (como nos Estados da Flórida e de Nova Iorque), atuando os mediadores na comunidade, e apenas posteriormente foram institucionalizados com a sua migração ao ambiente judicial, havendo então uma preocupação maior com a legalização e regulação estatal dos meios alternativos de solução de conflitos no âmbito do Judiciário, em busca de uniformização e incentivos aos programas.

Trata-se de um dos porquês acima expostos, sobre a institucionalização da mediação, que vê no Judiciário um aliado institucional a permitir que os programas de mediação contem com a confiança das partes e com suporte - inclusive orçamentário ${ }^{141}$ do Judiciário.

jurídicos, pluralismo jurídico, equidade e imparcialidade das decisões judiciais, por meio da criação de tribunais de pequenas causas e do fortalecimento e ampliação de serviços jurídicos gratuitos de qualidade. Já a proposta aprovada em 2004, criou um conjunto de instrumentos judiciais que centralizaram a tomada de decisões no Judiciário, ao mesmo tempo em que exigiu que ele fosse responsivo e transparente na prestação de um serviço de qualidade em termos de custos, tempo e capacidade técnica, produzindo decisões racionais e coerentes. Essa agenda "centralizadora e racionalizadora" da atividade judicial foi resultado de discursos que indicavam os impactos negativos do Poder Judiciário sobre a atividade econômica, principalmente no que diz respeito à morosidade no processamento dos casos e à falta de coordenação e padronização administrativa e jurisprudencial do Poder Judiciário". Cf. CUNHA, Luciana Gross. ALMEIDA, Frederico de. Justiça e Desenvolvimento Econômico na Reforma do Judiciário Brasileiro. Trabalho apresentado no evento sobre Direito e Desenvolvimento: um diálogo entre os BRICs, promovido pela Direito GV, Universidade de Wisconsin e ABDI, São Paulo, nov. 2010.

${ }^{140}$ Sobre os Neighborhood Justice Centers, a relação entre a mediação comunitária e institucional, vide HARRINGTON, Christine B. Shadow justice: the ideology and institutionalization of alternatives to Court. CT: Greenwood Press, 1985, pp. 105-169. Bush e Folger também registram este momento em que a mediação comunitária ganha visibilidade como um contraponto ao sistema formal de justiça (mesmo que antes a mediação já fosse comumente aplicada para conflitos trabalhistas). Cf. BUSH, Robert Baruch, FOLGER, Joseph. The promise of mediation cit., p. 7.

${ }^{141}$ Estes recursos podem ser provenientes de taxas judiciais, valores cobrados em inscrição de cursos de capacitação em mediação oferecidos pelo Judiciário ou de rubricas orçamentárias, tendo como objetivo a manutenção do programa, remuneração dos mediadores, dentre outras despesas. Waine Brazil elenca como possibilidades de fundos para os programas as seguintes: public sources (legislative grants, discretionary money within judicial budgets, etc), user fees, private foundations, Law firms, corporations, income from educational programs the Court sponsors, income from filing or other fees paid into Court by 
As partes confiam no Judiciário como foro de solução de conflitos. É importante ter em mente isso quando se pensa em institucionalização de meios alternativos no ambiente judicial $^{142}$. Pesquisa empírica realizada nos EUA revela a preferência das partes pelo processo judicial, divergindo da preferência dos juízes pela mediação e pelos demais meios alternativos de solução de conflitos. Nesta pesquisa foram entrevistados litigantes em demandas envolvendo responsabilidade civil e danos individuais, em três Cortes Estaduais, nas quais os casos tivessem sido resolvidos por julgamento judicial, arbitragem anexa à Corte, acordos em audiências judiciais ou acordos extrajudiciais entre as partes.

Os litigantes viram o julgamento judicial e arbitral como geradores de resultados mais justos do que os acordos, aparentemente porque eles acreditam que no Judiciário e arbitragem os casos recebem um tratamento mais respeitoso. Os acordos obtidos em juízo geram menos satisfação do que os acordos bilaterais, na opinião dos entrevistados, por ficarem normalmente abaixo das expectativas das partes. Em geral, a avaliação da justiça do processo e da satisfação com o resultado estão pouco relacionadas com o resultado objetivo, com os custos e a demora. Ao invés disso, a avaliação parece ser determinada mais pelas percepções dos litigantes sobre a justiça processual e suas expectativas sobre o resultado $^{143}$.

Assim, os litigantes teriam mais satisfação com processos nos quais se veem com oportunidade de dar voz ao seu prejuízo, de fazer defesas, e de serem tratados com dignidade, tendo suas demandas ouvidas e avaliadas por terceiros imparciais. Nesse sentido, de acordo com a pesquisa, eles veem os processos judicial e arbitral como

litigants/attorneys, general bar associations (not special interest groups). Cf. BRAZIL, Institutionalizing ADR cit., p. 106.

${ }^{142}$ Nesse sentido, Waine Brazil considera que: In thinking about institutionalizing ADR programs in courts it is imperative that we constantly bear in mind the immense importance of preserving public trust in the processes for dispute resolution that our society sponsors or provides. Our society cannot survive over time without such trust. Among other things, this means that our citizens must have confidence in our courts. They must perceive our courts as institutions dominated by the objective of delivering just results through thoroughly fair processes. Thus, when we beging to think about designing and implementing ADR programs we must be sure that neither the program we recommend nor the ways we justify or promote them undermine or detract from public trust in our courts as institutions. Cf. BRAZIL, Institutionalizing ADR cit., pp. 54-55.

${ }^{143}$ Cf. EBENER, Patricia A. et al. In the eye of the beholder: Tort litigants' evaluations of their experiences in the civil justice system. Law and Society Review, vol. 24, 1990, pp. 953-986. Gender, income, and race did not have much effect on evaluations. 
garantidores destas oportunidades, estruturando um diálogo entre as partes à luz de normas públicas, independentemente dos resultados gerados ${ }^{144}$.

No Brasil, em 2009, foi criado sob a coordenação de Luciana Gross Cunha o Índice de Confiança na Justiça (ICJBrasil), que visa a retratar sistematicamente a confiança da população no Judiciário. Trata-se de uma pesquisa trimestral, realizada em sete regiões metropolitanas brasileiras, que trabalha com dois subíndices: o subíndice de percepção, pelo qual é medida a opinião da população sobre a Justiça e a forma como ela presta o serviço público; e o subíndice de comportamento, através do qual se busca identificar a atitude da população, se ela recorre ao Judiciário para solucionar determinados conflitos ou não ${ }^{145}$.

Os dados do relatório do $3^{\circ}$ trimestre de 2010 seguem a tendência, já identificada nos trimestres anteriores, de má avaliação do Judiciário como prestador de serviços públicos ${ }^{146}$, mas embora o Judiciário seja considerado lento, caro e de difícil utilização, nas perguntas sobre comportamento, a maioria dos entrevistados declarou que certamente procuraria o Judiciário para resolver eventuais conflitos. $41 \%$ dos entrevistados declaram que já entraram com algum processo ou ação na Justiça (pessoalmente, ou alguém residente em seu domicílio) ${ }^{147}$.

\footnotetext{
${ }^{144}$ Vide considerações sobre esta pesquisa em RESNIK, Judith. Mediating preferences: litigant preferences for process and judicial preferences for settlement. Journal of dispute resolution, 2002, p. 160-161; e HENSLER, Deborah R. Suppose it's not true: challenging mediation ideology, 2002. J. Of Dispute Resolution 81, 85-93.

${ }^{145} \mathrm{O}$ subíndice de percepção é produzido a partir de um conjunto de nove perguntas em que o entrevistado deve emitir sua opinião sobre o Poder Judiciário no que diz respeito a: (i) confiança, (ii) rapidez na solução dos conflitos, (iii) custos do acesso, (iv) facilidade no acesso, (v) independência política, (vi) honestidade, (vii) capacidade para solucionar os conflitos levados a sua apreciação, (viii) panorama dos últimos 5 anos e (ix) perspectiva para os próximos 5 anos. Para a produção do subíndice de comportamento, foram construídas seis situações diferentes e pede-se ao entrevistado que diga, diante de cada uma das situações, qual a chance de procurar o Poder Judiciário para solucionar o conflito. As respostas possíveis para esta pergunta são: (i) não; (ii) dificilmente; (iii) possivelmente; (iv) sim, com certeza. Cf CUNHA, Luciana Gross (Coord.). Relatório ICJBrasil, 30 trimestre de 2010, $2^{\mathrm{a}}$ onda, Ano 2, p. 4. Disponível em http://www.direitogv.com.br/Default.aspx?PagId=DKHFMLQM\&navid=1262. Acesso em 20/12/2010.

${ }^{146}$ Para $89 \%$ dos entrevistados o Judiciário resolve os conflitos de forma lenta ou muito lentamente. $77 \%$ disseram que os custos para acessar o Judiciário são altos ou muito altos e $69 \%$ dos entrevistados acreditam que o Judiciário é difícil ou muito difícil para utilizar. Outros três problemas apontados pelos entrevistados são a falta de honestidade (63\% dos entrevistados consideram o Judiciário nada ou pouco honesto), a parcialidade (61\% dos entrevistados acreditam que o judiciário é nada ou pouco independente) e a falta de competência para solucionar os casos (55\% da população entrevistada classificam o Judiciário como nada ou pouco competente). Ibidem, p. 12.

${ }^{147}$ Ibidem, p. 15.
} 
Foi possível observar uma clara relação entre a utilização do Judiciário e a renda, a escolaridade e o local de residência da população. Assim, quanto maior a renda e a escolaridade, maior é a utilização do Judiciário. Da mesma forma, moradores dos grandes centros urbanos também utilizam mais o Judiciário se comparados aos moradores de cidades do interior $^{148}$.

Perguntou-se ainda a todos os entrevistados se caso enfrentassem algum tipo de conflito que necessitasse de resolução pelo Judiciário, se eles aceitariam tentar um acordo reconhecido pelo Judiciário, através de outra pessoa que não o juiz. $38 \%$ dos entrevistados disseram que sim, que aceitariam utilizar meios de solução de conflitos alternativos ao Judiciário (destaque-se que na faixa de renda de mais de $\mathrm{R} \$ 6.120,01$ e escolaridade alta, este percentual sobe para $45 \%$ ), mas a maioria respondeu negativamente, indicando que apesar da pouca confiança que tem no Judiciário ainda prefere utilizá-lo se comparada a soluções alternativas (mediação, conciliação) ${ }^{149}$.

\footnotetext{
${ }^{148}$ Ibidem, p. 15. E por que boa parte daqueles que vivenciaram conflitos não procuraram o Judiciário? O Relatório ICJBrasil identificou que o argumento mais frequente está relacionado aos aspectos de administração da justiça, pois $43 \%$ dos entrevistados que enfrentaram algum dos conflitos trabalhados na pesquisa dizem que não procuraram o Judiciário por achar que demoraria muito, seria caro, não sabiam como fazer para utilizar o serviço ou não confiavam no Judiciário. Outros 15\% afirmam que ainda estão esperando para entrar na Justiça (estão reunindo documentação, aguardando porque o caso é recente, conversando com advogados, etc). Para $12 \%$ o que os impediu foram questões pessoais (stress, problemas de saúde, etc), $20 \%$ não souberam responder o motivo de não ter procurado a Justiça, $5 \%$ afirmaram que não sabiam como fazer para utilizar, e apenas 3\% afirmam que resolveram o problema de outra forma (via PROCON, acordo, etc). Ibidem, p. 21.

${ }^{149}$ Ibidem, p. 22.
} 
Gráfico 1. Percentual de entrevistados que declararam que aceitariam utilizar meios alternativos de resolução de conflitos

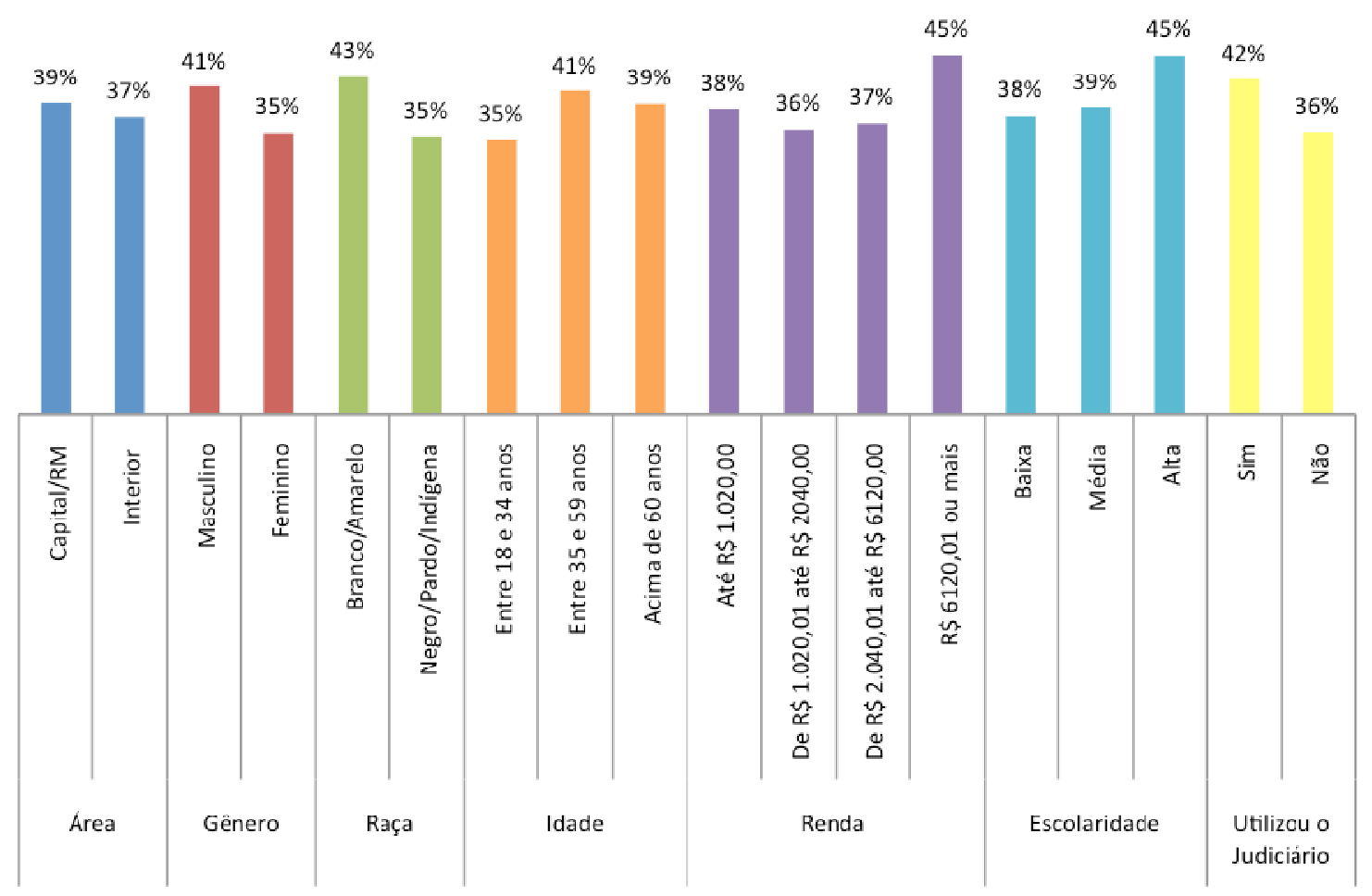

Fonte: Relatório ICJBrasil, $3^{\circ}$ trimestre de 2010.

A pedido do conselho Nacional de Justiça (CNJ), o Instituto Brasileiro de Geografia e Estatística (IBGE) incluiu na Pesquisa Nacional por Amostra de Domicílios 2009 (PNAD) o levantamento suplementar sobre Vitimização e Justiça no Brasil. A PNAD $2009^{150}$ entrevistou pessoas em todo o país e, no tema Justiça, buscou conhecer os tipos de conflitos vivenciados pela população brasileira nos últimos cinco anos e como as pessoas tentaram resolvê-los. Nestes casos, buscou-se saber se houve acionamento do Poder Judiciário ou de instância alternativa e quais foram os motivos que tenham desestimulado as pessoas a buscar a Justiça ou a procurar outros modos de solução.

De acordo com os dados coletados, nos últimos 5 anos, 12,6 milhões de pessoas de 18 anos ou mais de idade, que correspondem a 9,4\% desta faixa etária, estiveram envolvidas em situação de conflito. Destas, $51,1 \%$ eram homens e 48,9\%, mulheres.

\footnotetext{
${ }^{150}$ Trata-se de um sistema de pesquisas por amostra de domicílios que investiga diversas características socioeconômicas e demográficas e que, em 2009, agregou duas investigações suplementares: Vitimização e Justiça, em face de parceria com o Conselho Nacional de Justiça. Vide esta parte do relatório da pesquisa em http://www.ibge.gov.br/home/estatistica/populacao/vitimizacao_acesso_justica_2009/default.shtm. Acesso em 20/12/2010
} 
Das 12,6 milhões de pessoas com 18 anos ou mais de idade que estiveram em situação de conflito, $92,7 \%$ (11,7 milhões) buscaram solução, sendo que $\mathbf{5 7 , 8 \%}$ das pessoas recorreram à Justiça comum e $\mathbf{1 2 , 4 \%}$ ao Juizado Especial. Aqueles que não buscaram solução na Justiça para o conflito que tiveram $\mathbf{( 2 9 , 8 \%}$ ou 3,8 milhões de pessoas) apontaram alguns motivos para não o fazer. Dentre eles, destacaram o fato de a solução do problema ter ocorrido por meio de mediação ou conciliação (em 27,6\% dos casos) e a percepção de que demoraria muito resolver o conflito no Judiciário (em 15,9\% dos casos) ${ }^{151}$.

Chamou a atenção o percentual elevado de pessoas que buscaram métodos extrajudiciais de resolução de conflitos, como a mediação e conciliação, ao invés de ingressar com uma ação no Judiciário. Em entrevista, o Secretário Geral do CNJ destacou que é preciso ainda trabalhar para aumentar o índice de conciliação dentro do processo, que hoje é de cerca de $15 \%$ - ou seja, o número referente a pessoas que ingressaram com uma ação na Justiça e conseguiram terminar o processo por meio da conciliação ${ }^{152}$.

É muito importante diagnosticar e mapear estas preferências do jurisdicionado e da sociedade no momento do desenho e implementação de programas de mediação no Judiciário. O fato de estes programas funcionarem em um ambiente de legitimidade e confiança das partes influi também no papel assumido pelo Judiciário em relação à prestação de serviços e à democratização da justiça.

Quando se pergunta por que institucionalizar a mediação no âmbito do Judiciário, uma questão que também está no cenário e influencia a resposta a ser dada é relativa ao papel que exerce e ao papel que se espera do Judiciário: é ser um prestador de serviços eficiente, solucionando os conflitos que são apresentados pelas partes? É atuar e ter voz na

${ }^{151}$ Quanto aos temas levados ao Judiciário pela população, 23,3\% tiveram problemas trabalhistas, 20\% tiveram questões familiares, $12,6 \%$, criminais e 9,7\%, problemas com serviços de água, luz ou telefone. Em seguida vieram os conflitos relacionados a benefícios de previdência, representando 8,6\% das ações; problemas com bancos ou instituições financeiras, com 7,4\%; questões de terras e moradias, com 4,8\%; e conflitos ligados a impostos, com 1,2\%. Vide essas e outras informações no relatório disponível no link acima.

152 Vide notícia peiculada $\quad$ CNJ no site http://www.cnj.jus.br/index.php?option=com_content\&view=article\&id=13132: conciliacao-e-a-principalalternativa-a-resolucao-de-conflitos-na-justica\&catid=1:notas\&Itemid=675. $\quad$ Vide ainda http://www.conjur.com.br/2010-dez-16/ibge-75-populacao-soluciona-conflitos-justica. $\quad$ Acesso em $20 / 12 / 2010$. 
implementação de reformas institucionais, judicialização de relações sociais e de políticas públicas?

Segundo Luciana Gross Cunha, o debate sobre a administração e a distribuição da justiça pode ser organizado em torno desses dois eixos centrais: um que diz respeito à posição que o sistema de justiça ocupa na arena política desde a promulgação da $\mathrm{CF} / 88$, quando foram alargadas as áreas sujeitas à sua apreciação, tornando-se o principal árbitro nas disputas entre os Poderes Executivo e Legislativo; e um segundo que corresponde à sua eficiência na prestação de um serviço público ${ }^{153}$.

Em se pensando na função do Judiciário de prestador de serviços e solucionador de conflitos, os programas de mediação e conciliação podem ser ferramentas importantes à lógica eficientista de racionalizar, otimizar e tornar mais célere a prestação jurisdicional. Para Owen Fiss, todavia, a função primordial do Judiciário não é solucionar controvérsias, mas dar um significado adequado aos valores públicos e reorganizar instituições, atuando, assim, como ator político. É por esta razão e com esta premissa que Fiss articula críticas e aponta riscos à institucionalização da mediação no Judiciário, tal como se verá no capítulo 6 deste trabalho ${ }^{154}$.

Nos EUA, houve um significativo envolvimento do Estado e, em especial, do Poder Judiciário, em reformas sociais e estruturais. O movimento dos direitos civis em 1940 se voltou às Cortes Federais, que foi sede de interpretações constitucionais que mudaram o percurso da história em relação a variadas questões, como a igualdade racial e dignidade humana. Segundo Judith Resnik, a Justiça Federal era apenas uma parte de um projeto constitucional que a transcendia ${ }^{155}$.

$\mathrm{Na}$ era de reconhecimento de novos direitos e de sua efetivação junto às Cortes judicialização que teve seu ápice no período em que Earl Warren presidiu a Suprema Corte (1953-1969) - houve um aumento expressivo de casos nas Cortes Federais. Entre 1960 e 1990 os processos praticamente triplicaram de volume. É o que Resnik considera o Triunfo

\footnotetext{
${ }^{153}$ Cf. CUNHA, Juizado Especial cit., p.1.

${ }^{154}$ FISS, As formas de justiça. In: SALLES, Carlos Alberto de (Org). Um novo Processo Civil: estudos norte-americanos sobre jurisdição, constituição e sociedade. Coord. de tradução Carlos Alberto de Salles. São Paulo: Revista dos Tribunais, 2004, p. 26.

${ }^{155}$ RESNIK, For Owen cit, pp. 178-179.
} 
da Adjudicação, e que gerou uma série de consequências às Cortes. Uma delas foi o recurso a juízes auxiliares - os magistrate judges, special masters, administrative $e$ bankruptcy judges ${ }^{156}$.

O aumento de casos não necessariamente gerou o aumento do número de julgamentos, pois diferentemente do Brasil, onde há uma cultura da sentença e a proliferação crescente de decisões judiciais, a maior parte dos casos nos EUA terminam em acordo ${ }^{157}$. Segundo Galanter, esse declínio do número de julgamentos tem uma causa mais antiga e uma causa mais recente, verificada nos últimos vinte anos ${ }^{158}$.

A causa mais antiga está relacionada à impossibilidade de o Judiciário responder ao número cada vez maior de demandas: o potencial para invocar o Judiciário ("a day in Court") cresceu mais rapidamente do que o tamanho que a "planta" judicial poderia suportar, e o tempo de espera da decisão, os custos e nível de incerteza acabaram tornando $\mathrm{o}$ acordo mais atrativo do que o julgamento, ainda que o acordo fosse feito à sombra da lei (in the shadow of law) ${ }^{159}$.

Mais recentemente, segundo Galanter, nos últimos vinte anos, a redução do número de casos que chegaram às Cortes intensificou ainda mais a queda no número de julgamentos finais (trials), passando a prestação jurisdicional a ter como foco o gerenciamento na fase inicial do caso, o julgamento antecipado da lide, a promoção de acordos, dentre outros tipos de non-trial adjudication. O papel principal das Cortes passou a ser menos o de determinar e implementar normas públicas e mais o de agir como um facilitador da resolução de disputas, perspectiva que passou a predominar nas Cortes Federais a partir da década de 1970. O declínio de julgamentos estaria relacionado a mudanças ideológicas, de cultura jurídica e às práticas institucionais, que alteraram as

\footnotetext{
156 In this story trumpeting the "Triumph of Adjudication", markers of success include congressional creation of new federal rights and the filing of more cases. The legislature embraced adjudication by authorizing litigants to bring a widening array of lawsuits aimed at enforcing civil rights, environmental rights, consumers' rights, workers' rights. Between the 1960s and the 1990s, caseloads within the federal system tripled, as hundreds of new statutory causes of action were enacted. The demand soon outstripped the life-tenure judiciary, even as Congress was greatly augmenting its ranks. Life-tenured judges worked in tandem with Congress to manufacture non-life-tenured auxiliary judges, magistrate and bankruptcy judges, administrative Law judges, hearing officers, and the like, all of whom today comprise a workforce of some 4000 federal adjudicators committed to this national Project. Cf. RESNIK, For Owen cit., pp.180-181.

${ }^{157}$ Conforme nota de rodapé n. 7, na introdução deste trabalho.

${ }^{158}$ GALANTER, A world without trials cit., p. 12.

${ }^{159}$ GALANTER, A world without trials cit., p. 13.
} 
preferências e expectativas dos juízes, advogados, litigantes corporativos e, em menor medida, dos políticos, acadêmicos e da mídia em relação à confiança no Judiciário ${ }^{160}$.

O discurso foi de desregulação, privatização e perda da confiança no Governo, vendo-se na lei e na litigância elevados custos e incertezas, visão pessimista reforçada principalmente com a ascendência do mundo comercial e de negócios ${ }^{161}$. Como reação ao movimento de acesso à justiça houve a reforma das regras de responsabilidade civil (tort reform), que a partir de 1976 passou a estabelecer uma série de restrições à responsabilidade da empresa e às possibilidades de demandá-la em juízo, o que se somou às críticas ao ativismo judicial, à imprevisibilidade do júri e seus efeitos negativos ao desenvolvimento econômico ${ }^{162}$.

Para Galanter, essa aversão à adjudicação judicial é parte de um conjunto de crenças, opiniões e práticas: crenças de que estamos sofrendo uma explosão de litigiosidade, de que os jurados são parciais e contrários às empresas demandadas, de que as Cortes não devem continuar expandindo direitos, de que a litigância está causando prejuízo à economia, e que a solução é restringir remédios, privatizar e desregular, com o foco na institucionalização de novas práticas, como o gerenciamento dos casos, a incorporação de modalidades de mediação, a promoção do acordo, investimento em formas alternativas de solução de conflitos (ADR), dentre outras medidas que permitam o afastamento da responsabilidade das empresas de foros públicos como o judicial, onde os fatos são expostos e a responsabilidade abertamente declarada. Todavia, segundo este mesmo autor, se queremos um sistema legal no qual juízes e jurados adotem e sigam padrões públicos ao declarar a responsabilidade, particularmente dos atores mais poderosos, precisamos de julgamentos

\footnotetext{
${ }^{160}$ GALANTER, A world without trials cit., pp. 13-17.

${ }^{161}$ Ibidem, pp.19-20. Segundo Galanter: This shift encompasses the ascendancy of business within the legal system, as consumer of an increasing portion of legal services; the disproportionate growth of the (corporate hemisphere) legal profession; and the development of think-tanks, university programs, and public interest Law firms promoting pro-business policies, including massive campaigns to reduce legal obligations for business and to curtail legal remedies for others. It is part of a much broader turn from Law, a turn away from the definitive establishment of public accountability in adjudication. This aversion to adjudication is part of a mutually supportive complex of beliefs and practices-beliefs that we are suffering a litigation explosion, that juries as biased against corporate defendants, that courts should not be growing edge of rights, that litigation is hurting the economy, and that the solution is to curtail remedies, privatize, and deregulate. This turn is institutionalized in new court practices; intensive case management, incorporation of mediative modalities, promotion of settlement, diversion into ADR forums, accentuation of ADR forums and professionals. As a result, it has become embedded in the changing work habits of judges and lawyers who rarely engage in conducting trials. Ibidem, p. 22.

162 GALANTER, Marc. The hundred-year decline of trials and the thirty years war. Stanford Law Review Symposium, vol. 57, 2005, pp. 1269-1270.
} 
judiciais suficientes para que seja feito este trabalho ${ }^{163}$. Do contrário, o risco é que com poucos precedentes judiciais e referenciais objetivos que possam ser usados para planejar atividades e resolver disputas, na medida em que os julgamentos se tornam raros, o sistema de barganha sob a sombra da lei (bargaining in the shadow of law) se inverta para o de adjudicação sob a sombra da barganha (adjudication in the shadow of bargaining) ${ }^{164}$.

Um dos principais marcos no debate norte-americano sobre os meios alternativos de solução de conflitos no Judiciário ocorreu em 1976, na Pound Conference, que teve como mote o famoso discurso de Roscoe Pound, proferido em 1906 em Minnesota, sobre “As causas da insatisfação popular com a Administração da Justiça”. A Pound Conference visava dar continuidade aos trabalhos iniciados em 1906, sendo organizada pelo presidente da Suprema Corte, o Chief Justice Warren Burger, e promovida pela Judicial Conference of United States, the Conference of Chief Judges, e the American Bar Association. Foi nesta conferência que pela primeira vez Frank Sander tratou do sistema multiportas de solução de conflitos (Multi-door Courthouse), em discurso depois transcrito no artigo "Varieties of Dispute Processing"165. Ao invés de uma única porta direcionada ao Judiciário, um centro de solução de conflitos localizado na Corte poderia oferecer várias portas através das quais os indivíduos acessariam diferentes processos (mediação, arbitragem, factfinding, dentre outros).

Segundo Sander, este centro de solução de conflitos se destinaria quer às demandas já apresentadas à Corte quer às demandas ainda não ajuizadas (fase pré-processual), e desde então já alertava que o trade-off em melhorar o esquema de solução de conflitos seria aumentar o número de disputas a serem processadas, enfrentando uma litigiosidade antes contida. Maiores detalhes sobre o sistema multiportas serão analisados no capítulo 4 seguinte.

Nesse contexto de redução do julgamento pelo Judiciário, houve também a delegação de adjudicação às agências administrativas - administrative adjudication ${ }^{166}$

${ }^{163}$ GALANTER, The hundred-year decline of trials cit., pp. 1272-1274.

164 GALANTER, Marc. The vanishing Trial: what the numbers tell us, what they may mean. Dispute Resolution Magazine, vol. 4, 2004, p. 6.

${ }^{165}$ SANDER, Frank E. A. Varieties of Dispute Processing, In: A. Leo Levin and Russell R. Wheeler, The Pound Conference: Perspectives on Justice in the future. St. Paul: West Publishing Co., 1979, pp. 65-87

${ }^{166}$ Sobre a delegação de adjudicação às agências administrativas, vide RESNIK, Judith. Whither or Whether adjudication. Yale Law School, Public Law Working Paper No. 135, Disponível em 
além da migração de casos para outros foros e meios de solução de conflitos, como a mediação e arbitragem.

Os Alternative Dispute Resolutions (ADRs) começaram a ser adotados experimentalmente na Justiça Federal norte-americana a partir de 1970. Esta implementação contou com uma série de medidas: projetos pilotos, iniciativas experimentais a cargo de juízes, mudanças nas regras federais de processo civil, nas regras de processo civil locais, dentre outras ${ }^{167}$.

Percebe-se que quando os meios alternativos de solução de conflitos são institucionalizados no âmbito do Judiciário, há um aumento do controle estatal sobre estes, o que também gera como reação a demanda por um espaço institucional autônomo, não apenas sob a sombra do Judiciário. Isso foi observado na pesquisa empírica realizada, principalmente nos programas mais regulados, como na Flórida. A mesma dinâmica também se observa através do screening process (triagem do conflito), que é inicialmente controlada pelo Estado, pois os juízes (caso a caso) ou legisladores (em termos gerais) determinam suas regras, mas que tende a ser transferido posteriormente às partes, para que elas próprias façam suas escolhas em relação à forma de solução de conflitos.

Essa dinâmica relaciona-se com o papel pedagógico exercido pelo Judiciário ${ }^{168}$, como um condutor dos primeiros passos rumo à institucionalização dos meios alternativos de solução de conflitos, mas que tende a se retirar quando as partes se revelam "preparadas" para caminhar por conta própria, decidindo sobre a melhor forma de solucionar seus conflitos. Nessa perspectiva, é como se o papel do Judiciário em relação aos meios autocompositivos fosse instrumental, na medida em que se coloca mais ou

http://papers.ssrn.com/abstract=978806. Acesso em 20/12/2010.

167 A series of statutes, enacted between 1978 e 1998, at first authorized a number of pilot programs, and later specifically required federal courts to develop ADR processes for litigants; changes to the Federal Rules of Civil Procedure and local rules of procedure further fostered the use of ADR; finally, the informal efforts of judges to develop and administer ADR programs greatly aided its acceptance. ARTERTON, Janet Bond. Alternative Dispute Resolution in the District Court of Connecticut. In: MAZADOORIAN, Harry N. (Org). Mediation Practice Book: critical tools, techniques and forms. Law First Publishing and Quinnipiac University School of Law, 2002, p. 219.

${ }^{168}$ Sobre o papel pedagógico (education process) da mediação, destaca Wayne Brazil: Through a good ADR program, a court becomes a teacher of constructive ways to approach problem solving and the parties and lawyers can take the lessons they learn into the other aspects of their lives. BRAZIL, Continuing the conversation cit., p. 38. 
menos presente dependendo do momento e do nível de aceitação dos meios alternativos de solução de conflitos pelas partes e pela sociedade.

\subsection{Riscos da institucionalização: o outro lado da moeda}

Um dos principais riscos da institucionalização da mediação é que ela seja considerada uma justiça de segunda classe, sendo vista como uma forma de contenção dos casos que chegam ao Judiciário, que se dedicaria dessa forma apenas aos casos "mais importantes". Ao se criar uma porta de acesso aos meios autocompositivos, portanto, é preciso ter o cuidado de que ela não seja uma porta lateral ou secundária de acesso à justiça.

Waine Brazil destaca que quando apenas os índices de acordo e de redução de demandas são utilizados para medir o sucesso dos meios alternativos de solução de conflitos, o risco é passar a mensagem de que o Judiciário não quer que os litigantes e advogados o incomodem e sobrecarreguem com casos que poderiam ser enviados aos programas de meios alternativos (ADR), ficando fora das Cortes. Assim, com a institucionalização desses programas, como o de mediação, o juiz poderia guardar e direcionar sua energia para outras questões "mais relevantes". O risco de criação de uma justiça de segunda classe precisa ser evitado ao se desenhar os programas de ADR e definir os critérios pelos quais os conflitos são a eles direcionados ${ }^{169}$.

As polarizações entre justiça de $1^{\mathrm{a}}$ e de $2^{\mathrm{a}}$ classe, justiça de massa e justiça $\operatorname{artesanal}^{170}$, se considerarem a mediação/conciliação apenas como um filtro de contenção dos casos que chegam ao Judiciário, tornam-se bastante arriscadas. Os critérios para a

\footnotetext{
${ }^{169}$ Cf. BRAZIL, Continuing the conversation cit, p. 38. BRAZIL, Institutionalizing ADR cit., p. 90

${ }^{170}$ Os conceitos de magistratura de massa e artesanal são tratados no Brasil por Sidnei Beneti, que destaca dois tipos de processos e dois tipos de magistratura com que temos igualmente que conviver: a magistratura de massa e a magistratura artesanal. Esta última, a magistratura do caso concreto, do caso único, especial, determinado, cujos pormenores temos que identificar passo a passo, ponto por ponto, ao sabor das dificuldades e angústias dos singulares casos marcantes, que se destacam do volume geral de processos. Aquela, a magistratura da grande quantidade de situações processuais repetitivas, que acabam ganhando relevância operacional na razão direta do volume enorme de casos e pessoas envolvidas. Essa massa de trabalho precisa ser vencida, para que sobre tempo para os processos das questões para as quais será necessário trabalho artesanal. Cf. BENETI, Sidnei Agostinho. Da conduta do juiz. São Paulo: Saraiva, 2003, pp. 10-11.
} 
filtragem destes conflitos fazem toda a diferença, conforme se verá no capítulo 6 deste trabalho, assim como o significado atribuído aos filtros, que podem ser tanto filtros de contenção como de redirecionamento dos casos aos mecanismos adequados (consensuais ou adjudicatórios) de solução.

Esse risco de prover uma justiça de segunda classe aos cidadãos já tinha sido levantado durante a criação da Justiça de Pequenas Causas, que também previa um espaço importante para a conciliação, conforme se verá no item seguinte deste trabalho. Falava-se no perigo de os juizados transformarem-se em instrumento para a execução rápida de pequenos créditos, e, portanto, instrumento útil antes ao rico titular de muitos pequenos créditos do que ao pequeno devedor ${ }^{171}$, além da conciliação ser vista como um filtro dos casos menores e mais simples, deixando para os juízes a atuação nas grandes e mais importantes causas ${ }^{172}$.

Muito embora grande parte da resistência inicial aos Juizados Especiais tenha sido vencida com o passar do tempo pela prática, que referendou seu importante papel na democratização do acesso à justiça, os cuidados em relação à litigância repetitiva e ao contencioso de massa continuam sendo uma preocupação recorrente nos Juizados, que mesmo voltados às demandas individuais tem recebido levas de demandas repetitivas, como na área de consumidor, que podem colocar em risco o seu próprio funcionamento operacional $^{173}$.

${ }^{171}$ Cf. CAPPELLETTI, Problemas de Reforma cit, p. 123. Tratava-se do risco de proporcionar poor justice for the poor, levantado por algumas vozes. Segundo Cappelletti, há dois modos de recusar mudanças: um é simplesmente dizer não às reformas, o outro - talvez menos ostensivo, é exigir perfeição (o enfoque do tudo ou nada). Há situações em que a justiça conciliatória ou coexistencial é capaz de produzir resultados que, longe de serem de segunda classe, são melhores até qualitativamente do que os resultados do processo contencioso. Cf. CAPPELLETTI, Os métodos alternativos de solução de conflitos cit, pp. 89-90.

${ }^{172}$ Nas palavras de um dos conciliadores dos Juizados Especiais Cíveis de São Carlos: "Eu acho que os juízes não devem perder o tempo deles com causas pequenas, com coisas que poderiam ser resolvidas de outra maneira. Então eu acredito que foi por aí que se resolveu criar um mecanismo para desafogar a justiça. Eu acredito que os juízes devem se ater a grandes causas, a coisas mais complexas (...). Então, nada melhor que um conciliador para fazer isso. É melhor ter vários conciliadores. O juiz tem o seu tempo a peso de ouro". Cf. FAISTING, Andre Luiz. O dilema da Dupla Institucionalização do Poder Judiciário: o caso do Juizado Especial de Pequenas Causas. In: SADEK, Maria Tereza (Org.). O sistema de justiça. São Paulo: IDESP: Sumaré, 1999, p. 54.

${ }^{173}$ Desenvolvidos para resolverem litígios de impacto individual, os Juizados vêm recebendo ações inadequadas à sua estrutura simplificada e conciliatória. De acordo com pesquisa empírica realizada por Leslie Ferraz, a maioria de demandas nos Juizados está relacionada à área de consumo (atingindo picos de 50,8\% em São Paulo, 55,3\% em Minas Gerais e 79\% no Rio de Janeiro), mas é justamente nesse tipo de demandas que os operadores dos Juizados apontaram existir uma menor probabilidade de solução amigável. A análise qualitativa dos Juizados sugere que causas que envolvem pessoas jurídicas e/ou que cuidam de relação de consumo apresentam uma menor chance de composição amigável. Demandas de consumo que 
Segundo Humberto Pinho, seria um erro grave pensar em executar mediações em série, de forma mecanizada, como hoje, infelizmente, se faz com as audiências prévias ou de conciliação, nos juizados especiais e na justiça do trabalho, pois a mediação é também um trabalho artesanal. Cada caso é único e demanda tempo, estudo, e análise aprofundada das questões sob os mais diversos ângulos ${ }^{174}$.

Notou-se que a conciliação tende a lidar com um volume maior de casos do que a mediação, podendo atuar na esfera das disputas e nos limites do objeto do processo judicial, com um procedimento mais simples, voltado ao acordo, e sem que a relação entre as partes tenha que ser continuada. Já a mediação trabalha mais profundamente as facetas do conflito e os interesses das partes que estão por trás das disputas, estando voltada a relações continuadas, com um processo que demanda mais tempo e que não tem o acordo como meta, mas apenas como um dos resultados possíveis.

Entretanto, quando inseridas no ambiente judicial, tanto a mediação quanto a conciliação estão inevitavelmente sujeitas ao volume de demandas e ao perfil de litigância que chega ao Judiciário. Nesse sentido, destaca Deborah Hensler a importância de se identificar as necessidades e os problemas do sistema judicial antes de se desenvolver os programas alternativos a ele $\mathrm{e}^{175}$.

Um dos riscos e problemas especialmente relacionado com as demandas repetitivas é o de que esse volume de demandas seja direcionado à mediação/conciliação sem critérios e triagem adequada, e a quantidade de acordos obtidos não esteja acompanhada do elemento qualitativo, o que influi na percepção das partes quanto à justiça do processo e do resultado e reflete diretamente no posterior (des)cumprimento dos acordos. O efeito

envolvem interesses individuais homogêneos e coletivos acabam sendo indevidamente distribuídas e aceitas nos Juizados, como ocorreu no caso da contestação da tarifa básica de assinatura de telefonia no Estado de São Paulo, por exemplo, comprometendo a sua estrutura operacional. Cf. FERRAZ, Leslie Sherida. A conciliação nos Juizados Especiais Cíveis: uma análise empírica. In: SALLES, Carlos Alberto de (Org.). As grandes transformações do processo civil brasileiro: homenagem ao professor Kazuo Watanabe. São Paulo: Quartier Latin, 2009, pp. 407-408.

${ }^{174}$ Cf. PINHO, Humberto Dalla Bernardina de. A mediação e a necessidade de sua sistematização no processo civil brasileiro. p. 9. Disponível em http://www.humbertodalla.pro.br/index.htm. Acesso em 20/12/2010.

${ }^{175}$ Deborah Hensler destacou esta preocupação em painel sobre avaliação de programas alternativos de solução de conflitos, realizado em 1991 na National Conference on Emerging ADR issues in the State and Federal Courts. Segundo a autora, evaluators should attempt first to identify needs or problems in a court system prior to developing the structure and operation of the programs. Evaluation research can then help to formulate program design. Cf. SANDER, Frank E. A. Emerging ADR Issues in State and Federal Courts, American Bar Association, 1991, p. 29. 
perverso disso é que, sendo a obtenção do acordo uma medida meramente paliativa e quantitativa que não ataca as causas do conflito e não se preocupa com a relação entre as partes, acordos gerem mais acordos, volume gere mais volume, sem uma solução efetiva dos conflitos, o que é imprescindível para o subsequente cumprimento dos acordos. Ademais, avaliar o sucesso dos programas de mediação tendo como único critério o número de acordos obtidos pode também gerar o aumento de pressão dos conciliadores sobre as partes, atividade que não é monitorada e que pode estar por trás do crescimento da quantidade de ajustes.

Sob o argumento da crise do Judiciário, que enfrenta elevada taxa de congestionamento e alto nível de litigiosidade, os mecanismos alternativos de solução de conflitos são incentivados como uma forma de acesso à justiça que reduz e filtra os processos que chegam ao Judiciário. A visão da mediação como uma forma de remediar as patologias do Judiciário (morosidade e custos) é traduzida pelo famoso ditado de que mais vale um mau acordo do que uma boa demanda judicial.

O discurso de combate à morosidade processual pela mediação e outros meios alternativos, entretanto, não pode perder de vista que quando se abre uma nova porta aos conflitos, esta porta não é apenas de saída (via acordos que extinguem o processo), mas também de entrada de novos conflitos (litigiosidade contida), que podem ganhar visibilidade e gerar demandas no Judiciário, sem que isso deva ser interpretado como algo necessariamente negativo.

É um risco apostar nos meios alternativos como um remédio à crise do Judiciário $^{176}$. Sob esse viés, quando se analisa por que a mediação e conciliação vêm sendo incentivadas pelos juízes ou pelo Tribunal, entram em cena questões relacionadas primordialmente à redução da morosidade e à melhora na administração da justiça. Segundo pesquisa realizada nos EUA, há certo distanciamento entre as preferências dos

\footnotetext{
${ }^{176}$ Nesse sentido, Kazuo Watanabe destaca: "Não é porque o Poder Judiciário está sobrecarregado de serviço que tentaremos descobrir formas de aliviar a carga. Tenho um grande receio de que a mediação venha a ser utilizada com esse enfoque e não com o maior, que seria dar tratamento adequado aos conflitos que ocorrem na sociedade; não se pode pensar nela como uma forma de aliviar a sobrecarga a que o Judiciário está sendo submetido hoje, porque daremos à mediação o mesmo encaminhamento que estamos dando aos juizados especiais". WATANABE, Kazuo. Modalidades de Mediação. Série Cadernos do CEJ, n. 22, Brasília: Conselho da Justiça Federal, 2001, pp. 45-46.
} 
juízes e as das partes, pois os juízes não estão falando em nome dos litigantes, mas também em nome de seus próprios interesses e experiências ${ }^{177}$.

As causas que afastam os juízes do julgamento estão relacionadas ao volume e morosidade da prestação jurisdicional. Segundo Resnik, os juízes passaram a fazer parte do $A D R$ lobby ${ }^{178}$, e encorajam acordos privados defendendo que estes acordos conferem tanto quanto a adjudicação poderia oferecer ${ }^{179}$. Mais uma vez, o cuidado deve ser com o risco de promover uma second best solution.

O bom funcionamento do Judiciário é essencial para que outros métodos de solução de conflitos se desenvolvam positivamente. Um não deve ser pensado para corrigir as insuficiências do outro, devendo haver uma relação de cooperação que leve a um círculo virtuoso e não vicioso entre os métodos de solução de conflitos.

Um outro risco a ser destacado é a baixa adesão voluntária aos programas de mediação que funcionam junto às Cortes. Nesse sentido, Reuben aponta o grande hiato que existe entre o crescente suporte institucional que tem sido dado aos meios alternativos de solução de conflitos nas Cortes e o seu uso voluntário pelas partes, ainda baixo, o que teria múltiplas causas, sendo a principal delas relacionada a questões culturais ${ }^{180}$.

Waine Brazil também trata desta questão, apontando a pouca participação das partes quando o programa de mediação é voluntário. Há normalmente desconfiança das partes e dos advogados, medo do desconhecido, de tornar o procedimento ainda mais longo, ter mais trabalho, assumir riscos e sair da zona de conforto em que estão acostumados a agir, além do receio dos advogados de reduzir ou ter que mudar a forma de cobrança de honorários. Assim, aquele autor acredita que ao menos até que haja uma mudança cultural suficiente para gerar maior adesão voluntária aos meios alternativos ao Judiciário, a melhor abordagem seria torná-los obrigatórios para tipos de casos que, por

\footnotetext{
${ }^{177}$ RESNIK, Mediating preferences cit, p. 162.

${ }^{178}$ RESNIK, For Owen cit., p. 193.

179 Judges encourage private accords because those agreements provide as much - or as little - as adjudication can offer. Cf. RESNIK, Mediating preferences cit, p. 165

${ }^{180}$ Reuben cita o estudo de James S. Kakalik et al., An Evaluation of Mediation and Early Neutral Evaluation Under the Civil Justice Reform Act 48-53 (RAND 1996) e palestra de Deborah Hensler em 1997 na Universidade de Stanford sobre este baixo uso dos meios alternativos, que contariam mais com um suporte institucional do que com uma efetiva demanda das partes - interest in ADR may in fact be supply driven, rather than demand driven. Cf. REUBEN, Constitutional Gravity: a Unitary Theory cit, p. 981-983.
} 
critérios objetivos, pareçam mais prováveis de se adaptar ao processo de mediação e que reforcem a importância e utilidade dos programas anexos às Cortes. Os casos poderão ser retirados do programa caso as partes demonstrem não julgar apropriada esta tentativa de solução autocompositiva, peticionando ao juiz ${ }^{181}$. Este é o modelo adotado no programa de mediação pesquisado em Maine, no qual há a presunção de que os conflitos são passíveis de mediação, salvo prova em contrário das partes (presumptive mediation).

Segundo McAdoo, Welsh e Wissler, a mediação obrigatória não parece afetar a percepção dos litigantes quanto à justiça do processo ou mesmo quanto à obtenção de acordos. Ao contrário, o maior ativismo do juiz em determinar que as partes se submetam à mediação parece estimular o crescimento de seu uso voluntário, fazendo com que os advogados expostos à mediação passem a requerê-la antes mesmo da manifestação do juiz, além de aumentar a probabilidade de que eles discutam ou mesmo recomendem este processo aos seus clientes ${ }^{182}$.

É pela baixa adesão voluntária que a mediação obrigatória é defendida muitas vezes no início da implementação do programa no Judiciário, dado o seu efeito pedagógico junto às partes em demonstrar como funciona esta forma autocompositiva de solução de conflitos. A obrigatoriedade não está relacionada à obtenção do acordo, mas à submissão das partes à mediação. A crítica que se faz quanto a essa obrigatoriedade é de que sem a anuência e vontade de ambas as partes em participar deste momento autocompositivo, a mediação não tem utilidade e nem potencial para se desenvolver, criando-se apenas uma fase a mais no procedimento, quando incidental ao processo judicial, o que eleva os custos e o tempo de demora.

No Brasil, um dos grandes óbices à adoção da mediação obrigatória é a inafastabilidade da jurisdição, resguardada constitucionalmente pelo art. $5^{\circ}$, XXXV da $\mathrm{CF} / 88$. Para combatê-lo, Carlos Alberto de Salles ressalta a necessidade de a garantia da inafastabilidade ser entendida de forma a permitir a assimilação pelo sistema jurídico de mecanismos alternativos à prestação do serviço judiciário pelo Estado, como medidas de substituição ou de apoio à jurisdição estatal. Analisando a hipótese de a mediação ou conciliação serem obrigatórias, como um pré-requisito para o acesso ao Judiciário, este

${ }^{181}$ Cf. BRAZIL, Institutionalizing ADR cit., pp. 122-124.

${ }^{182}$ Cf. MCADOO et al. Institutionalization cit., pp. 8-9. 
autor traz à tona os requisitos que hoje já existem para o exercício do direito processual de ação: os pressupostos processuais e as condições da ação. Considera que estes requisitos não seriam ontologicamente diferentes daqueles que poderiam ser estabelecidos em relação aos meios alternativos de solução de controvérsias, condicionando o acesso ao Judiciário à prévia realização de mediação, mas em todo caso está em jogo matéria política a ser definida pelo legislador ${ }^{183}$.

Nos EUA, a mediação é obrigatória em alguns Estados (como é o caso da Califórnia e da Flórida, por exemplo). Na Argentina, desde outubro de 1995, foi estabelecida a obrigatoriedade da instância prévia de mediação aos processos judiciais ${ }^{184}$. Hoje há a mediação pré-judicial obrigatória, o que significa que antes de submeter o conflito ao Judiciário, devem as partes se submeter a uma sessão de mediação (condição de procedibilidade) $)^{185}$.

Por fim, a institucionalização deve evitar o risco de engessamento do desenho e de sua regulação, devendo haver espaços para revisões, mudanças, e para iniciativas criativas e responsivas ao contexto em que se insere o programa, assim como espaço para ouvidoria dos usuários quanto ao que tem dado certo e ao que poderia ser melhorado. A institucionalização, dessa forma, embora implique em uma maior estabilidade ao programa (instituído por normas que regulam seu procedimento e funcionamento) deve ter possibilidades de adaptações que se façam necessárias, construídas a partir da experiência e do monitoramento de dados empiricamente observados (controle de qualidade).

\footnotetext{
${ }^{183}$ Cf .SALLES, Mecanismos Alternativos cit., pp. 779-780/ 782-783.

${ }^{184}$ A Lei $24.573 / 2005$ foi substituída recentemente pela lei $26.589 / 2010$, que reitera o caráter obrigatório da mediação previa aos processos judiciais, e regulamenta a comunicação direta entre as partes para a solução extrajudicial da controvérsia, devendo os mediadores serem advogados. Antes disso, em 19.08.1992 o Poder Executivo Nacional declarara, através do Decreto n. 1480/92, ser de interesse nacional a institucionalização e o desenvolvimento da mediação como método alternativo para a solução de controvérsias e, por Resolução de 18.09.1992, o Ministério da Justiça regulamentara a criação do Corpo de Mediadores.

185 Vide ABREVAYA, Sergio Fernando. Evaluación del sistema de mediación prejudicial. La Trama Revista Interdisciplinaria de mediación y resolución de conflictos, Ciudad Autónoma de Buenos Aires, dez. 2007, pp.1-22.
} 


\subsection{A institucionalização da conciliação nos Juizados Especiais Cíveis}

A conciliação nos Juizados Especiais Cíveis vai ao encontro dos objetivos relacionados à democratização do acesso à justiça. A Lei no 9099/95 prevê a existência de conciliadores e de juízes leigos, tendo sido os Juizados Especiais de Pequenas Causas precedidos pelos Juizados Informais de Conciliação.

Os Juizados Especiais foram o ponto de partida para que a conciliação se inserisse na política judiciária como uma forma de aprimorar a administração da justiça e, principalmente, de dar maior visibilidade a conflitos que antes não chegavam ao Judiciário $^{186}$. Era preciso, entretanto, que esta iniciativa atingisse o processo tradicional, não ficando restrita ao microssistema dos Juizados Especiais ${ }^{187}$, expansão que veio a ocorrer posteriormente.

André Luiz Faisting considera que, no caso dos Juizados, houve uma dupla institucionalização no Poder Judiciário, no sentido de que há duas formas distintas de prática judiciária, baseadas em lógicas também distintas: uma que visa o acordo entre as partes por meio da conciliação, conduzida por advogado que desempenha a função de conciliador, e outra que busca a aplicação da justiça por meio do poder de decisão do juiz. Estas duas lógicas representam, portanto, uma tensão entre as duas pautas distintas da justiça contemporânea: a justiça informal de mediação e a justiça formal de decisão ${ }^{188}$.

Os conciliadores e mediadores assumem um papel importante na administração da justiça. Segundo Kazuo Watanabe, a possibilidade de participação da comunidade nas coisas que dizem respeito à administração da justiça foi uma inovação importante que ocorreu nos Juizados através das figuras do conciliador e do árbitro, que prestam serviço

\footnotetext{
${ }^{186}$ Destaca Ada Pellegrini que a justiça conciliativa não atende apenas a reclamos de funcionalidade e eficiência do aparelho jurisdicional, sendo impróprio falar-se em racionalização da justiça, pela diminuição da sobrecarga dos tribunais, se o que se pretende, através dos equivalentes jurisdicionais, é também e primordialmente levar à solução controvérsias que até agora não chegavam sequer a ser apreciadas pela justiça tradicional. Cf. GRINOVER, Ada Pellegrini. A conciliação extrajudicial no quadro participativo. In: GRINOVER, Ada Pellegrini, DINAMARCO, Candido Rangel e WATANABE, Kazuo (Org.). Participação e Processo. São Paulo, Revista dos Tribunais, 1988, p. 282.

${ }^{187}$ Cf. LORENCINI, Marco Antônio Garcia Lopes. A contribuição dos meios alternativos para a solução das controvérsias. In: SALLES, Carlos A (Org). As Grandes Transformações do Processo Civil Brasileiro. Homenagem ao Prof. Kazuo Watanabe. São Paulo: Quartier Latin, 2009, p. 611.

${ }^{188}$ FAISTING, $O$ dilema da Dupla Institucionalização cit., pp. 43-44.
} 
voluntário. Os atrativos que a lei local venha a estabelecer poderão potenciar esse espírito comunitário, que inegavelmente existe e explica a persistência, por exemplo, da instituição do júri, que funciona à base do trabalho honorário dos jurados ${ }^{189}$.

Para Dinamarco, a conciliação é a alma do processo das pequenas causas. $\mathrm{Na}$ conciliação, depositaram-se as melhores esperanças de pacificação social, que constitui a ratio legis das inovações em estudo. Sob a direção e superior orientação do juiz, os conciliadores fariam de tudo para aproximar os contendores (lei de pequenas causas, art. $23)^{190}$.

Ada Pellegrini, por sua vez, ao escrever sobre Conciliação e Juizados de Pequenas Causas, também considerou que o escopo precípuo dos Juizados de Pequenas Causas é a busca incessante de conciliação.

Delineia-se, nesse quadro, a necessidade de repensar a conciliação, até como meio para evitar o processo, mediante soluções de mediação institucionalizada, a qual possa funcionar como canal idôneo para resolver certos conflitos, principalmente no nível de pequenos litígios: os direitos dos consumidores, a composição dos danos mais leves, o direito de vizinhança, certas questões de família e as conexas ao crédito e tantas outras contendas poderiam encontrar na conciliação o instrumento adequado para uma pronta e pacífica solução ${ }^{191}$.

Ainda nas palavras desta autora, "os Juizados de Pequenas Causas e as tentativas institucionalizadas de conciliação representam tendências que se completam, quais face e verso da mesma medalha. Essa afirmação não é desmentida pela inegável constatação de que a conciliação pré-processual pode constituir meio de solução dos litígios, alternativo e substitutivo ao processo. Ao contrário, mostra a recíproca interação entre formas de mediação que visam a subtrair certos litígios à solução exclusivamente judicial, e a instituição de um tipo específico de procedimento para os mesmos litígios, sempre que as tentativas de autogestão e de autocomposição não alcancem êxito"192.

\footnotetext{
${ }^{189}$ WATANABE, Kazuo. Filosofia e características básicas do Juizado Especial de Pequenas Causas. In: WATANABE, Kazuo (Org.). Juizado especial de pequenas causas: Lei 7.244, de 7 de novembro de 1984. São Paulo: Revista dos Tribunais, 1985, p. 6.

${ }^{190}$ DINAMARCO, Cândido Rangel. O processo no Juizado das Pequenas Causas. In: WATANABE, Kazuo (Org.). Juizado especial de pequenas causas: Lei 7.244, de 7 de novembro de 1984. São Paulo: Revista dos Tribunais, 1985, p. 135.

${ }^{191}$ GRINOVER, Ada Pellegrini. Conciliação e Juizados de Pequenas Causas. In: WATANABE, Kazuo (Org.). Juizado especial de pequenas causas: Lei 7.244, de 7 de novembro de 1984. São Paulo: Revista dos Tribunais, 1985, p. 148.

${ }^{192}$ Ibidem, p. 159
} 
Ada Pellegrini considera uma tripla função da conciliação: a função eficientista (voltada à funcionalidade e eficiência do aparelho jurisdicional), a função política (de participação popular na administração da justiça) e a função social (que visa à pacificação social), não sendo estas funções excludentes, mas coexistentes e complementares. Reconhece ainda que a mediação e conciliação passam ao status de instrumentos utilizados no quadro da política judiciária, como verdadeiros equivalentes jurisdicionais ${ }^{193}$.

Os juízes, ao serem colocados diante de situações que envolvem relações sociais cada vez mais dinâmicas e complexas, apostaram na conciliação como solução para muitas das demandas, muito embora eles não tenham sido preparados para serem conciliadores, uma vez que são formados e socializados em uma cultura institucional baseada no poder de decidir, na lógica formal da decisão e não na lógica informal da mediação ${ }^{194}$.

Os conciliadores apontam para a necessidade de criação de uma nova identidade profissional, sustentando o exercício de uma função específica e diferente dos outros advogados e dos juízes. Ao mesmo tempo em que buscam se diferenciar dos advogados formalistas e litigantes, buscam aliança com um segmento dos juízes e dos cartorários, no intuito de alcançarem a legitimidade e reconhecimento necessários ao exercício de sua função. Isto mostra que a construção desta identidade não é monolítica, mas sim múltipla e contraditória $^{195}$.

Andre Faisting ressalta, por outro lado, que alguns riscos podem advir também dos interesses conservadores da magistratura. Para este autor, os juízes buscam seguir controlando as duas justiças (formal e informal) e impedir, com isso, que uma nova classe de juízes leigos ou conciliadores assuma o controle da justiça informal, impondo a estes o caráter de auxiliares da justiça e impedindo seu maior poder e autonomia profissional. Desta forma, o Judiciário garantiria o controle da justiça informal por meio da homologação dos acordos que são realizados pelos conciliadores nas sessões de conciliação. Conclui, nestes termos, que a dupla institucionalização do Judiciário, com a

\footnotetext{
${ }^{193}$ GRINOVER, Os Fundamentos da Justiça Conciliativa cit,, pp. 3-5.

${ }^{194}$ Cf. FAISTING, O dilema da Dupla Institucionalização cit., p. 50.

195 Ibidem, pp. 50-51.
} 
regulamentação da justiça informal e a busca de nova identidade profissional pelos conciliadores, teria vários desafios pela frente ${ }^{196}$.

\subsection{Meios autocompositivos: entre o comunitário e o institucional}

Além das razões e riscos acima apresentados para institucionalizar a mediação, uma das questões importantes a enfrentar é se esta institucionalização deve ser um ponto de partida ou de chegada, ou seja, deve-se partir do comunitário ao institucional ou do institucional ao comunitário? Ou ambos devem caminhar juntos?

Sendo a mediação uma via de acesso à justiça, a porta de entrada ao conflito pode se situar em diferentes cenários ou contextos, pode estar em um ambiente comunitário, familiar ou empresarial, ser realizada de forma ad hoc ou institucional, em esfera pública ou privada, relacionada a questões cíveis ou penais, ser voluntária ou obrigatória, dentre outras características que pode assumir. Neste capítulo são consideradas algumas diferenças entre a mediação institucional e a mediação comunitária, estando situado o objeto deste trabalho na esfera institucional e estatal, especificamente no âmbito do Judiciário.

Alguns programas de mediação, entretanto, começaram informalmente como centros de mediação comunitária (como nos Estados da Flórida e de Nova Iorque), e apenas posteriormente foram institucionalizados com a sua migração ao Judiciário, o que representou uma forma de garantia e também de controle.

Kazuo Watanabe considera o papel do Estado em relação aos meios alternativos de solução de conflitos sem excluir a importante participação da comunidade na administração da justiça. O grande exemplo foi a experiência dos Juizados Informais de Conciliação e Juizados de Pequenas Causas. Sobre o papel do Estado, destaca este autor:

Incumbe ao Estado organizar todos esses meios alternativos de solução dos conflitos, ao lado dos mecanismos tradicionais e formais já em funcionamento.

${ }^{196}$ Ibidem, p. 50/57. 
Tais serviços, que podem ser informais, não precisam estar organizados dentro do Poder Judiciário. Podem ficar a cargo de entidades públicas não pertencentes ao Judiciário (v.g., Ministério Público, Ordem dos Advogados, PROCON, Defensoria Pública, Procuradoria de Assistência Judiciária, Prefeituras Municipais) e até de entidades privadas (v.g., sindicatos, comunidades de bairros, associações civis). É importante que o Estado estimule a criação desses serviços, controlando-os convenientemente, pois o perfeito desempenho da Justiça dependerá, doravante, da correta estruturação desses meios alternativos e informais de solução dos conflitos de interesses

(...)

A participação da comunidade e a adoção de técnicas alternativas de solução de conflitos, principalmente a conciliação e o arbitramento, e ainda a tendência à deformalização (mais informalidade) e delegalização (menos legalismo e solução de conflitos, em certos casos, pela equidade) tem constituído a grande inovação desses Juizados. A par das vantagens mais evidentes, que são a maior celeridade e maior aderência da Justiça à realidade social, a participação da comunidade traz, ainda, o benefício da maior credibilidade da Justiça e principalmente o do sentido pedagógico da administração da justiça, propiciando o espírito de colaboração ${ }^{197}$.

Ainda que um dos objetivos seja a deformalização do processo, nota-se uma forte presença do Judiciário e do Estado na organização e incentivos aos meios alternativos de solução de conflitos. Sobre esta presença estatal, ressalta Maria Tereza Sadek que historiadores e cientistas sociais costumam chamar a atenção para a peculiaridade da incorporação dos direitos no Brasil. Inversamente do que ocorreu no mundo europeu ocidental e mesmo nos Estados Unidos da América, entre nós, a construção da cidadania não resultou, fundamentalmente, de lutas sociais para a inclusão de direitos e garantias. A liderança no processo esteve mais a cargo do Estado, ou como sintetiza José Murilo de Carvalho, trata-se de uma cidadania constituída de "cima para baixo"198.

É importante considerar, todavia, que a institucionalização da mediação junto ao Judiciário deve ser vista como uma das formas possíveis de incentivo e suporte à

${ }^{197}$ WATANABE, Acesso à Justiça e Sociedade Moderna cit, p. 133.

198 Cf. SADEK, Maria Tereza. Juizados Especiais: Um novo paradigma. In: SALLES, Carlos Alberto de (Org.). As grandes transformações do processo civil brasileiro: homenagem ao professor Kazuo Watanabe. São Paulo: Quartier Latin, 2009, pp. 419-420. Marco Antonio Lorencini também reconhece a forte presença do Estado e da Jurisdição estatal no centro do sistema de justiça. Segundo este autor, "A história da jurisdição estatal é a história do próprio Estado, pois à medida que concentrou o poder em suas mãos é que passou a ser delineado o seu exercício, ou seja, o desempenho dessa função e atividade estatal que constituem a jurisdição. (...) $\mathrm{O}$ esforço para enfatizar o aspecto público do direito processual civil fez com que fosse esquecida a noção de jurisdição como atividade secundária, segundo a qual essa, uma vez provocada, só atua se frustrado o cumprimento espontâneo daquilo que se encontra previsto na norma de direito material". Conclui o autor que "A forte presença do Estado na história brasileira sufocou as outras manifestações espontâneas de resolução de controvérsias. Uma forma de resgatar o encontro entre a adjudicação e os demais meios de solução de controvérsias é entender a inafastabilidade da jurisdição como obrigação de o Estado prestar o serviço de justiça, lançando mão, assim, não apenas da adjudicação, mas de outros meios de solução de controvérsias. Além de tolerar estas manifestações além da sentença judicial, a tarefa do Estado passa a ser também a de estabelecer políticas públicas para que as formas de solução de controvérsias que não a sentença estatal se espraiam, dentro e fora do ambiente do Poder Judiciário" Cf. LORENCINI, A contribuição dos meios alternativos cit., p. 603/622. 
mediação, sem excluir outras portas de acesso à mediação, não atreladas a mecanismos judiciais e estatais. É o que prevê a terceira hipótese deste trabalho. Mais do que definir, portanto, se o ponto de partida deve ser comunitário ou institucional, é importante garantir que ambos se desenvolvam e caminhem juntos em favor da mediação.

Segundo Glaucia Foley, o resgate dos meios autocompositivos de solução de conflitos nos EUA, nas décadas de 60 e 70, é um processo resultante de dois movimentos sócio-políticos aparentemente contraditórios, um com foco institucional e outro com foco comunitário:

\begin{abstract}
De um lado o ADR mostrou-se um remédio para lidar com o excessivo número de demandas judiciais que, uma vez não absorvidas pelo sistema oficial, causaram insatisfação e descrédito na justiça. Era o direito em abundância, expressão cunhada por Galanter para expressar o fenômeno de inflação jurisdicional, verificado em um momento de grande atividade política voltada para a defesa dos direitos. De outro, o movimento ADR constituiu um meio de contestação da centralidade do monopólio estatal, visando valorizar o espaço comunitário e estimular a participação ativa na solução dos conflitos. O propósito era o de promover a reapropriação da gestão dos conflitos pela comunidade ${ }^{199}$.
\end{abstract}

A mediação institucional e a mediação comunitária, para Jean Six, são passíveis de distinção segundo a origem dos terceiros facilitadores da solução do conflito (mediadores estabelecidos no alto ou que se colocam embaixo, nas palavras do autor) e os seus respectivos modos de ação ${ }^{200}$. Os mediadores institucionais e mediadores comunitários, embora distintos, devem estar em cooperação, dialogando entre si acerca de suas respectivas práticas e funções, mesmo que cada um esteja atuando dentro da sua esfera e de seu papel ${ }^{201}$.

\footnotetext{
199 FOLEY, Glaucia Falsarella. Justiça Comunitária: por uma justiça de emancipação. Belo Horizonte; Editora Fórum, 2010, pp. 68-69.

${ }^{200}$ SIX, Dinâmica da Mediação cit., pp. 28-29. Segundo este autor, os mediadores comunitários são diferentes dos mediadores institucionais: são mediadores naturais, que nascem nos grupos sociais e atuam de acordo com as necessidades da comunidade. São cidadãos entre cidadãos e atuam de igual para igual. Eles não tem mais do que a autoridade moral. O desenvolvimento urbano, a dispersão das famílias e os movimentos da população enfraqueceram consideravelmente a presença e papel destes mediadores, que foram substituídos por associações, pelo terceiro setor. Ibidem, pp. 31-32

${ }^{201}$ Ibidem, p. 45. Assim, para Six "há dois tipos de mediação e nenhum dos dois, salvo se se quiser destruir a mediação, pode se impor unilateralmente e eliminar o outro; eles têm, portanto, de viver juntos. De uma parte, a mediação "homem": uma mediação emitida por um poder, vinda de cima, proveniente de algum organismo constituído qualquer - a mediação institucional. De outra parte, a mediação "mulher": uma mediação independente, suscitada pela vida cotidiana, na base, em livre associação - a mediação cidadã." Ibidem, p. 2.
} 
A mediação comunitária promove uma cultura baseada na autodeterminação, sendo uma forma de gestão dos conflitos que permite que as pessoas e atores sociais assumam papéis mais ativos, sendo assistidas pelos mediadores ${ }^{202}$.

Um dos programas de mediação analisados na pesquisa empírica deste trabalho volta-se à mediação comunitária (Programa de Justiça Comunitária do Distrito Federal), não obstante conte com o apoio institucional do Executivo, através do Ministério da Justiça e da Secretaria Nacional de Segurança Pública, e do Judiciário. Para suplantar os custos de informação e acesso à justiça, o programa divide-se em três frentes: educação jurídica, animação de redes sociais e mediação comunitária, conforme se verá no capítulo 5.

Segundo Glaucia Foley, juíza que coordena este programa, há dois modelos de mediação: o modelo de agência, cujo enfoque é voltado para a satisfação das partes, geralmente operado em práticas de mediação vinculadas ao sistema judicial oficial, e o modelo comunitário, que oferece uma perspectiva transformadora porque direcionado à organização comunitária ${ }^{203}$. O programa de Justiça Comunitária do Distrito Federal estaria neste segundo modelo.

A mediação comunitária pode ser também uma forma de se dar voz a conflitos que ficariam sem solução. É o que Kazuo Watanabe denomina de "litigiosidade contida", referente a conflitos que não são canalizados ao Judiciário para a solução estatal, e que podem ficar completamente sem solução, muitas vezes até pela renúncia total do direito pelo prejudicado. Watanabe tratou desses conflitos quando defendeu a implementação dos Juizados Especiais, como uma forma de resgatar ao Judiciário a credibilidade popular e fazer renascer no povo, principalmente nas camadas média e pobre, a confiança na justiça e o sentimento de que o direito deve ser defendido. O fenômeno da litigiosidade contida poderia ser extremamente perigoso para a estabilidade social, sendo um ingrediente a mais na "panela de pressão" social, que já estava demonstrando sinais de deteriorização do seu sistema de resistência. ${ }^{204}$

${ }^{202}$ NATÓ, Alejandro Marcelo; QUEREJAZU, Maria Gabriela Rodriguez; CARBAJAL, Liliana Maria. Mediación Comunitária: conflitos en el escenario social urbano. Buenos Aires: Universidad, 2006, p. 85.

${ }^{203}$ Cf FOLEY, Justiça Comunitária cit, pp. 101-102.

${ }^{204}$ Cf. WATANABE, Filosofia e características básicas do Juizado Especial cit., p. 2. 
Para Maria Tereza Sadek, o fato de um grande número de pessoas não procurar a justiça formal deve ser sublinhado, na medida em que indica tanto que muitos problemas não vêm sendo resolvidos pela instituição encarregada de fazê-lo, quanto que outros canais podem estar ocupando este espaço. Para esta autora, a resolução pacífica de conflitos pode ser atingida por mais de um mecanismo: por técnicas extrajudiciais (mediação, conciliação, arbitragem), organização da sociedade civil (igrejas, associações, clubes, sociedades de amigos de bairro) ou por decisão judicial. Este último mecanismo supõe, antes de tudo, o império da lei, a crença nas instituições judiciárias e um mínimo de conhecimento a respeito delas, das leis e de sua aplicabilidade ${ }^{205}$.

De outra parte, é importante mencionar o mapeamento nacional realizado pelo Ministério da Justiça, através da Secretaria de Reforma do Judiciário, em parceria com o Programa das Nações Unidas para o Desenvolvimento - PNUD, em 2005, dos programas públicos e não governamentais de solução alternativa de $\operatorname{conflitos}^{206}$. O objetivo foi identificar os programas existentes, sem fins lucrativos, saber onde estavam localizados, volume de atendimento, que tipo de conflitos e de público atendiam, quanto custavam e quem os financiava, servindo o mapeamento para fins de construção de uma política pública para a difusão de sistemas alternativos de solução de conflitos.

Nos programas governamentais procurou-se apurar o grau de institucionalidade a partir de existência de portaria de criação e regulamentação, provimento de cargos, e existência de orçamento específico para o programa. Nas organizações nãogovernamentais procurou-se verificar a abrangência de sua atuação (local, nacional ou internacional), a sua área de atuação, as formas de financiamento mais utilizadas, e o grau de profissionalização da organização e do programa.

Os programas estavam sediados tanto em instituições governamentais - como Tribunais de Justiça, Defensorias Públicas, Secretarias estaduais, órgãos municipais quanto em entidades não-governamentais - organizações da sociedade civil; podendo também ser frutos de parcerias entre duas ou mais organizações, estatais ou da sociedade

\footnotetext{
${ }^{205}$ SADEK, Maria Tereza Aina. O sistema de Justiça. In: SADEK, Maria Tereza (Org). O sistema de justiça. São Paulo: IDESP: Sumaré, 1999, p. 9.

${ }^{206}$ BRASIL. Ministério da Justiça. Secretaria de Reforma do Judiciário. Acesso à Justiça por Sistemas Alternativos de Administração de Conflitos: mapeamento nacional de programas públicos e não governamentais. Brasília: 2005. Disponível em http://portal.mj.gov.br/. Acesso em 20/12/2010.
} 
civil. Sem a pretensão de expressar a totalidade das experiências de solução alternativa de conflitos em curso no país, esta pesquisa realizou importante levantamento de dados: mapeou 67 programas, sediados em 22 estados do Brasil. Destas 67 iniciativas em curso no ano de 2004, 33 eram programas criados por instituições públicas governamentais, e 32 desenvolvidos por organizações não-governamentais, além de dois programas criados por universidades.

Entre os programas governamentais (total de 33) predominaram aqueles instituídos no âmbito dos Poderes Judiciários Estaduais (17 programas, 51\%), sendo 10 deles criados por Tribunais de Justiça e o restante criado em varas e juizados. Menos de um terço dos programas governamentais foi criado por órgãos do Poder Executivo (10 iniciativas), sendo os programas estaduais mais frequentes do que os municipais. Houve o registro de dois programas criados por Defensorias Públicas e um por Ministério Público Estadual.

Tabela 1. Distribuição dos programas governamentais de administração alternativa de conflitos segundo o poder que o instituiu

\begin{tabular}{l|r}
\hline Poder & Frequência \\
\hline Poder Judiciário & $\mathbf{2 0}$ \\
\hline Executivo Direto & $\mathbf{1 0}$ \\
\hline Defensoria Pública & 2 \\
\hline Ministério Público & $\mathbf{1}$ \\
\hline Total & $\mathbf{3 3}$ \\
\hline
\end{tabular}

Fonte: Sistemas de administração alternativa de conflitos - SRJ/MJ e PNUD.

A pesquisa em tela identifica, assim, o Poder Judiciário como um dos principais fomentadores da resolução alternativa de conflitos entre os órgãos governamentais. Observou-se algum investimento por parte dos Executivos Estaduais, sobretudo através das Secretarias de Justiça ou de Cidadania. Executivos Municipais (total de 6 programas) também apresentaram algum investimento, ligado a políticas de proteção aos direitos humanos e políticas de prevenção de violência. Deve-se destacar, contudo, que este mapeamento foi realizado em 2005 e é passível de alterações, muito embora o que se tenha 
observado no Judiciário é a sua participação e atuação crescentes no fomento e implementação de programas de resolução alternativa de conflitos.

Quanto ao grau de institucionalização dos programas de solução alternativa de conflitos no interior das instituições governamentais, verificou-se que 22 dos 33 programas (66\%) estavam formalmente instituídos por alguma norma (portaria, resolução, decreto ou lei), sendo quatro deles criados por lei. Se a existência de norma de criação e regulamentação aponta no sentido de haver certo grau de institucionalização, visão diferente se tem ao analisar a existência de orçamento específico e cargos destinados ao programa: apenas nove deles $(27 \%)$ afirmaram possuir orçamento específico; oito (24\%) dispunham de cargos instituídos especificamente para o programa e, quando isso ocorreu, predominou um número pequeno de cargos criados (inferior a 7 cargos), dados que indicam a precariedade organizacional da maioria dos programas.

Não se pode dizer que a utilização de administração alternativa de conflitos seja necessariamente uma alternativa à intervenção estatal nesse campo, já que o Estado, através de diferentes agências governamentais, financia a maior parte dos programas estudados, seja diretamente prestando esse tipo de serviço ao cidadão, seja financiando ou estabelecendo convênios e parcerias com organizações civis.

Glaucia Foley, por sua vez, classifica os mecanismos de solução de conflitos utilizando as seguintes variáveis: regulatório/emancipatório e estatal/não estatal. O modelo emancipatório é o campo de exercício da retórica, enquanto que no regulatório impera o direito permeado pela coerção e/ou burocracia; a variável estatal ou não estatal, por sua vez, está relacionada às práticas jurídicas levadas a efeito dentro ou fora do âmbito oficial. Nada impede a combinação entre estas variáveis - uma prática não estatal regulatória (é o exemplo da arbitragem) ou estatal emancipatória (o que pode acontecer na mediação judicial). A conciliação, neste caso, estaria no campo estatal regulatório, próxima da retórica persuasiva, e a mediação comunitária, no campo não estatal emancipatório. $\mathrm{O}$ nível de regulação é medido pela burocracia e coerção; e o da emancipação, pela retórica persuasiva ou dialógica presente ${ }^{207}$.

${ }^{207}$ FOLEY, Justiça Comunitária cit, pp. 70-73. A autora se baseia na análise de Boaventura Sousa Santos para considerar que retórica, burocracia e coerção são os três componentes estruturais do direito que podem se articular sob diferentes combinações, a depender do campo jurídico ou dentro de um mesmo campo. 
Nesse sentido, a lógica da mediação obedece a um padrão dialógico, horizontal e participativo, o qual inaugura um novo enfoque para o tema da realização da justiça. Por isso Foley considera que mesmo nos modelos atrelados ao sistema judicial, a estrutura da mediação pode veicular em sua gênese um potencial emancipatório, na medida em que sua lógica subverte o padrão adversarial do sistema. Adverte a autora, entretanto, que "além da mediação processual ser um instrumento voltado tão somente àquela camada social que tem acesso ao Sistema de Justiça, a intensidade da energia emancipatória que pode ser produzida nas experiências concretas estará intimamente ligada à adoção do espaço comunitário como locus preferencial ${ }^{208, "}$

Conforme uma das hipóteses deste trabalho, quanto mais próxima do ambiente institucional do Judiciário, maiores são as preocupações acerca da identificação das bases constitutivas do processo de mediação (devido processo legal mínimo). Tendo o Judiciário como um aliado institucional, o que permite que se obtenha a confiança das partes em relação à mediação e o suporte do Judiciário nos programas e centros que funcionam junto às Cortes, esta parceria não deve ser considerada como um fim em si mesma, pois a mediação precisa em algum momento sair da sombra do Judiciário e conquistar o seu espaço autônomo.

No caso da mediação comunitária, afastada do ambiente judicial, os contornos processuais da mediação tendem a ser menos regulados, além de estar menos sujeita ao controle e certificação estatal.

Há setores de mediação pré-processuais que atuam antes da propositura de qualquer ação judicial. Embora sejam uma porta de ingresso ao conflito situada fora do ambiente judicial, muitos estão próximos ao Judiciário ou mesmo contam com o seu apoio institucional. Na cidade de São Paulo, por exemplo, há setores pré-processuais e postos de conciliação, como o que atua em parceria com a Associação Comercial de São Paulo e com o Simpi - Sindicato da Micro e Pequena Indústria. Trata-se de uma das Unidades Avançadas de Atendimento, reguladas pelo provimento do Conselho Superior da Magistratura $\mathrm{n}^{\mathrm{o}} 1077 / 2006$. Neste caso, os acordos obtidos podem ser homologados pelo juiz coordenador do setor de conciliação, transformando-se em títulos executivos judiciais

${ }^{208}$ Ibidem, p. 82. 
A mediação, quando no Judiciário, se coloca como intermediária, na fronteira entre o jurisdicionado e o juiz. Trata-se de uma primeira acolhida do conflito. Segundo SIX, a mediação judicial é uma forma de exercício de ação pública, estando no quadro da instituição judiciária e sendo compatível com os procedimentos judiciais ${ }^{209}$.

A mediação incidental ou processual ocorre depois de já movimentada a máquina judicial, com a apresentação de petição inicial, eventual recolhimento de custas, despacho liminar, citação do réu, prazo para contestação, diligências cartorárias, resposta do réu, designação de audiência prévia, sem contar com os inúmeros incidentes processuais que podem tornar mais complexa a relação processual $^{210}$

Humberto Pinho defende uma ampliação conceitual do interesse de agir, fundado no binômio necessidade-utilidade, para que as partes tenham que demonstrar em juízo que tentaram, de alguma forma, buscar uma solução consensual do conflito antes de ingressarem no Judiciário. Segundo este autor, "não há necessidade de uma instância prévia formal extrajudicial, como ocorre com as Comissões de Conciliação Prévias na Justiça do Trabalho, bastando algum tipo de comunicação, como o envio de uma carta ou email, uma reunião entre advogados, um contato com o call center de uma empresa feito pelo consumidor; enfim, qualquer providência tomada pelo futuro demandante no sentido de demonstrar ao Juiz que o ajuizamento da ação não foi sua primeira alternativa",211.

O juiz, caso se convença das alegações do autor, proferiria o despacho liminar positivo e determinaria a citação do réu; se entendesse, ao contrário, que há espaço e viabilidade para uma solução pacífica, designaria uma sessão de mediação (incidental), uma vez convencido de que o mecanismo poderá, concretamente, ofertar alguma contribuição ao litígio que tem em suas mãos. Para Humberto Pinho, seria um verdadeiro despautério cogitar da existência, em um mesmo processo, de uma sessão de mediação, de uma audiência preliminar e ainda uma audiência de instrução e julgamento na qual, novamente, tenta-se a conciliação ${ }^{212}$.

\footnotetext{
${ }^{209}$ SIX, Dinâmica da Mediação cit, p. 160

${ }^{210} \mathrm{Cf}$. PINHO, A mediação e a necessidade de sua sistematização cit, p. 20.

${ }^{211}$ Ibidem, p. 18.

${ }^{212}$ Ibidem, p. 22-23.
} 
Assim, Humberto Pinho defende que a conciliação ou mediação deva ser préprocessual, facultando-se às partes a possibilidade de provocar o Poder Judiciário para obter a homologação do acordo (e com isso mais segurança jurídica para aquela relação); iniciado o fluxo processual, a opção da conciliação fica sempre aberta, mas não cabe ao juiz provocá-la ou mesmo interromper a marcha dos atos processuais no afã obsessivo de alcançá-la ${ }^{213}$.

Há controvérsias sobre o nível de ingerência estatal - especificamente do Judiciário - que deve haver na promoção dos meios alternativos de solução de conflitos contrapondo-se o âmbito institucional ao comunitário, a esfera pública à esfera privada. Esses debates têm por base o papel pedagógico do Judiciário e de suas decisões para a escolha da forma mais adequada de solução de conflitos pelas partes, estando por trás deste protagonismo judicial muitas vezes um argumento de insolidarismo social sob a justificativa da não organização e não mobilização da sociedade civil no gerenciamento e solução de seus próprios conflitos.

\subsection{O juiz de paz}

A importância de se estudar o juiz de paz está em perceber os seus aspectos comunitários e institucionais.

O juiz de paz ou juiz leigo está em um contexto que Mauro Cappelletti denomina de justiça coexistencial ou social. Trata-se de uma forma de participação popular na administração da justiça que, assim como o júri, tem uma finalidade de legitimação democrática da função jurisdicional e de educação cívica das pessoas que, como juízes leigos, podem exercer funções conciliatórias ${ }^{214}$. Nas palavras deste autor: "a utilização de juízes de paz, por exemplo, desde que escolhidos em função da pertinência à comunidade no âmbito da qual devem operar, pode revelar-se elemento de estímulo, além de aproximação da justiça à própria comunidade" 215.

\footnotetext{
${ }^{213}$ Ibidem, p. 23.

${ }^{214}$ CAPPELLETTI, Problemas de Reforma cit, p. 124-125

${ }^{215}$ Ibidem, p. 126.
} 
No Brasil, o papel do juiz de paz foi previsto na Constituição do Império. Tratavase de um juiz eleito, com função de promover a conciliação entre as partes antes de qualquer processo judicial, conforme revelam os artigos da constituição transcritos a seguir:

\begin{abstract}
Art. 161. Sem se fazer constar, que se tem intentado o meio da reconciliação, não se começará Processo algum.

Art. 162. Para este fim haverá juízes de Paz, os quaes serão electivos pelo mesmo tempo, e maneira, por que se elegem os Vereadores das Camaras. Suas attribuições, e Districtos serão regulados por Lei.
\end{abstract}

Em 15.10.1827 foi promulgada a Lei $\mathrm{n}^{\circ}$ 0-026, que criou em cada uma das freguesias e das capelas curadas um juiz de paz e suplente. Segundo esta lei (conhecida como a lei orgânica das Justiças de Paz), poderia se candidatar a juiz da paz aquele que pudesse ser eleitor, sem necessidade de formação jurídica.

Esta lei orgânica da Justiça de Paz marcou um importante momento de reforma liberal. Formalmente, tratava apenas de um tipo de juiz leigo e não remunerado que desempenhava funções de menor monta, conciliando litigantes, dividindo o Distrito em quarteirões e julgando eventuais contravenções às posturas municipais, crimes de menor potencial ofensivo, procedendo à auto de corpo de delito e a formação de culpa dos delinquentes, além de resolver dúvidas sobre o uso de caminhos privados, pastos e direitos de caça e pesca, danos ocasionados por escravos e animais domésticos, dentre outras atribuições previstas em lei.

Mas por trás desta figura palpitavam debates institucionais importantes, tendo os reformadores liberais feito do juiz de paz um verdadeiro portador de suas preocupações práticas e filosóficas sobre formas democráticas de governo, localismo, autonomia e descentralização, enquanto os conservadores viam este magistrado local como uma ameaça à autoridade central e controle social de um vasto Império. $\mathrm{O}$ debate sobre a atuação do juiz eleito se converteu em um dos assuntos mais palpitantes no começo do Império brasileiro $^{216}$.

${ }^{216}$ FLORY, Thomas. El juez de paz y el jurado en el Brasil imperial, 1808-1871: Control social y estabilidad política en el nuevo Estado. Traducción de Mariluz Caso, México: Fondo de Cultura Econômica, 1986, p.81. Vários periódicos da época registraram o advento desta lei com entusiasmo, conforme transcrições a seguir: Luis Augusto May, el brusco veterano del periodismo de Rio, cuya preocupación absorbente desde la Independência había sido la creación de un gobierno local eficaz, escribió en su Malagueta que "un juez de paz fuerte es ahora nuestra piedra filosofal" (A Malagueta, 13.02.1829). A 
Segundo Thomas Flory, o juiz de paz, um funcionário judicial aparentemente de pouca importância, foi a pedra angular dos planos de reforma liberal para o governo local que se apresentaram ao final de 1820 e início de 1830. O seu âmbito de atuação - a paróquia local ou freguesia - se revelava como o microcosmo brasileiro ideal para se conhecer e implementar possíveis reformas $^{217}$.

Este juiz veio restringir - e em alguns casos até mesmo substituir - as atribuições do juiz de fora, juiz ordinário, juiz de vintena, o juiz pedâneo e almotacel, os quais representavam a justiça real portuguesa atuante no Brasil até então. Os juízes de paz se contrapunham aos juízes que, formados na Faculdade de Direito de Coimbra, representavam no Brasil um laço forte com o governo real e aplicavam a lei friamente, sem considerar as condições e dinâmicas locais da sociedade.

Em meio a uma justiça lenta, cara e não confiável, além da atuação policial pouco eficaz, o juiz de paz passou a simbolizar um afastamento desejável em relação à metrópole e a implementação de uma política de descentralização já prevista pela Constituição de 1824. Tratar-se-ia de um juiz independente, eleito pela população e que ficaria de fora do controle do Imperador.

Seguindo a dinâmica paradoxal da legislação que misturava o geral com o específico, o importante com o insignificante, a atuação do juiz de paz variava bastante. Era, nas palavras de Thomaz Flory, "en parte un magistrado respetado y poderoso, en parte un palurdo bostezante; en cierto momento arbitrando importantes diferencias

\footnotetext{
Astréia, un periódico de pronunciadas inclinaciones nativistas, indetificó a los enemigos del Julgado de Paz como enemigos de la nación, y rezó: "ojalá que el Cielo Le dé vida y fuerza a este árbol majestuoso para felicidad de todos los brasileños (A Astréia, 8.07.1830). El Jornal do Comércio, que era más reservado, mientras defendia constantemente al gobierno en contra de sus críticos, hizo hincapié en la contribución del emperador al referirse a la nueva instituición como "el dulce y apreciable fruto de nuestra Constitución" (O Jornal do Comércio, 21.10.1829). (...) O Astro de Minas, pariente ideológico del periódico liberal más influyente de Rio, Aurora Fluminense, llenó sus columnas con notícias de las actividades de jueces de paz. específicos, sus elecciones, y consideraciones sobre la institución en general. Para O Astro, el juez de la parroquia era "la más santa de las instituiciones", y el periódico relato esperanzadamente el progresso de la gente para “aprender a amar el nuevo sistema” (O Astro de Minas, 7.03 e 03.12 de 1829, 06.03, 18.09 e 25.09 de 1832) - Ibidem, pp. 93-94. ${ }^{216}$

${ }^{217}$ Ibidem, p. 54-57. Para um aprofundamento sobre a justiça de paz, vide ainda: LOPES, Levindo Ferreira. Manual dos juizes de paz. Ouro Preto: Silva Cabral, 1892. VASCONCELLOS, J. M. P. de. Actos dos juizes de paz. Rio de Janeiro: Laemmert, 1862. MENDONÇA, José Xavier Carvalho de. Tratado theorico e pratico das justiças de paz. Rio de Janeiro: Garnier, 1889.
} 
legales o dirigiendo fuerzas armadas, y en el seguiente saliéndoles al paso a los borrachos y sermoneando a las prostitutas ${ }^{, 218}$.

A atuação dos juízes de paz se dava no âmbito municipal, concentrando as Câmaras (juízes e vereadores que a compunham) poderes jurisdicionais, administrativos e policiais.

Depois da abdicação do Imperador em 1831, as perspectivas políticas dos liberais que estavam em oposição se ampliaram e isso se fez sentir também com o aumento da jurisdição e poderes de vigilância conferidos aos juízes de paz, que chegaram a assumir funções policiais, o que se consagrou principalmente com o advento do Código de Processo Criminal de 1832. O sistema judicial português era então revisto, com a promulgação de novos códigos e de uma estrutura judicial própria ao Brasil - além do Código de Processo Criminal de 1832, foi promulgado em 1830 o Código Penal.

Nesse sentido, ressalta Victor Nunes Leal que "importante reforma de nosso sistema policial e judiciário, de inspiração descentralizadora, foi realizada pelo Código de Processo Criminal, de 29 de novembro de 1832, que deu extraordinário relevo à figura do juiz de paz, investido de amplos poderes. Até sua alteração em 1841, foi esta uma das leis mais discutidas no país" ${ }^{219}$.

O Código de Processo Criminal atacou os restos formais do sistema legal português e adotou uma estrutura de organização judicial tipicamente brasileira, fortalecendo instituições liberais existentes como o juiz de paz. Segundo Thomas Flory, com justa razão teria se considerado este código como a personificação da filosofia jurídica liberal, uma contribuição nativa que privilegiava as instituições locais, sendo o juiz de paz a pedra angular da judicatura na época ${ }^{220}$.

Esse estereótipo positivo criado pelos liberais sobre os juízes de paz, contudo, não durou por muito tempo. Com a ascensão política dos conservadores, esta imagem cedeu lugar a diversas críticas reacionárias, como, por exemplo, a de que o fato de esses juízes serem homens de outras profissões e interesses, que buscavam ampliar seu círculo de

${ }^{218}$ FLORY, El juez de paz cit., p. 98.

${ }^{219}$ LEAL, Victor Nunes. Coronelismo, enxada e voto: o Município e o Regime Representativo no Brasil. São Paulo: Alga Omega, 1986, pp. 189-190.

${ }^{220}$ FLORY, El juez de paz cit, p.175-179. 
influência junto à comunidade em uma política de troca de favores, fazia com que não se pudesse esperar deles uma atuação como funcionários modelos ${ }^{221}$.

Aos poucos ficaram claras algumas desvantagens, em termos de política nacional, de colocar assuntos locais em mãos privadas, e os magistrados profissionais - os letrados, antes taxados pelos liberais como uma mera extensão do governo imperial - passaram a buscar maiores espaços e poderes nas esferas judicial e política ${ }^{222}$. O ápice desta crítica reacionária é simbolizado pela reforma do Código de Processo Criminal em 1841, que modificou a organização judicial e política nacionais então vigentes.

A reforma do Código Processual implementada em 03.12.1841 visou desmontar a estrutura judicial liberal antes criada, neutralizando-se o juiz de paz e tornando os juízes dos tribunais inferiores novamente dependentes do governo central, além de elegíveis apenas entre os graduados nas Faculdades de Direito (magistrados profissionais).

Assim como um dos principais objetivos do Código Processual de 1832 dos liberais havia sido fortalecer o juiz de paz, a meta da lei de contra-reforma dos conservadores de 1841 foi a de enfraquecer este funcionário local. A nova lei dividia os poderes deste juiz entre os novos funcionários da polícia e justiça nomeados pelo poder central, reduzindo as atribuições do juiz de paz às atividades conciliatórias e esvaziando as suas demais funções ${ }^{223}$.

Os juízes de paz eram vistos cada vez mais sob a dependência dos magnatas locais. Sobre estas ligações, ressaltou o Deputado Pedro Aleixo: “os juízes de paz pertencem a partidos políticos, a facções políticas e muitos deles vivem preocupados com os interesses facciosos do seu grupo. Ora, entre as funções que, comumente, se atribuem ao juiz de paz, está a de substituir o juiz municipal e, às vezes, o próprio juiz de direito. (...) De conluio o juiz partidário e o delegado faccioso, não haverá adversário que lhe resista (Anais, XI, p. $403,1934)^{224}$.

\footnotetext{
${ }^{221}$ Ibidem, p. 110.

${ }^{222}$ Ibidem, p. 133/138.

${ }^{223}$ Ibidem, p. 266-267

${ }^{224}$ LEAL, Coronelismo, enxada e voto cit, p. 203.
} 
Chegou-se inclusive a vislumbrar a possibilidade de remunerar o juiz de paz como uma forma de reduzir a sua vulnerabilidade em relação aos grupos locais, mas esta proposta derradeira não chegou a reverberar e suplantar as criticas às reformas implementadas pelos liberais no período regencial. Ao invés de um juiz popular independente, buscou-se então o controle institucional da burocracia judicial nacional e a centralização garantida pelos magistrados profissionais, que reascenderam no cenário político e judicial brasileiros.

Com a criação da polícia, em 1841, foram subtraídas dos juízes de paz as funções policiais que antes exerciam, com poucas mudanças práticas em relação à subordinação da polícia aos chefes locais ${ }^{225}$.

Mais tarde, uma das expressões de independência institucional durante a República foi o estabelecimento de garantias de inamovibilidade, vitaliciedade e irredutibilidade de que passaram por lei a gozar os juízes federais, e que em 1926 foram estendidas aos juízes estaduais. "Donos” de seus cargos, não tendo mais a ameaça de perseguição do mandão local visando suprimí-los, expulsá-los, desterrá-los para os confins do Estado, puderam eles julgar faltas e crimes sem sofrer uma influência demasiadamente opressora por parte dos coronéis ${ }^{226}$.

Segundo Victor Nunes Leal, a reação contra o judiciário policial dos liberais de 1832, com as funções policiais entregues a juízes de paz eletivos, foi certamente excessiva com a inversão operada - o policialismo judiciário - confiadas às autoridades policiais funções nitidamente judiciárias ${ }^{227}$.

\footnotetext{
${ }^{225}$ Conforme ressalta Maria Isaura, "pelo Código de Processo Criminal, de 1832, o juiz de paz tinha amplos poderes na repressão da criminalidade, o que equivalia a dizer que esta repressão estava nas mãos dos senhores rurais, pois os juízes da paz eram eleitos, nos diferentes distritos de que se compunha o município, e não era eleito quem não tivesse a aprovação do chefe político local. Desse modo, crimes cometidos por parentes e agregados do chefe político ficavam inteiramente impunes, enquanto os crimes dos adversários eram rigorosamente castigados. A criação de uma instituição policial, com chefes de policia nomeados pela Corte, delegados e subdelegados nomeados pelos presidentes das províncias, podia cercear a autoridade dos senhores rurais. Tal não se deu, porém. Estes pobres delegados e subdelegados, perdidos no fundo do sertão, não dispondo de forças para efetuar prisões, isolados pela distância dos centros provinciais e muito mais ainda da capital do Império, só puderam viver acolhendo-se à sombra do mandão local”. QUEIROZ, Maria Isaura Pereira de. O Mandonismo local na vida política brasileira e outros ensaios. São Paulo: Alfa Omega, 1976, p. 70.

${ }^{226}$ QUEIROZ, O mandonismo local cit., p. 206.

${ }^{227}$ LEAL, Coronelismo, enxada e voto cit, pp. 193-194
} 
Uma das principais atribuições do juiz de paz era promover conciliações, mas havia certa incompatibilidade do papel de conciliador com as benesses e poderes que o juiz de paz auferia pelo seu cargo eletivo ${ }^{228}$. Nesse sentido, destaca Flory que "como funcionários electos que debían su posición a una de dos o más partes locales contendientes, los magistrados generalmente carecian de la autoridad moral de la imparcialidad que está implícita en el concepto de conciliación" ${ }^{\text {229. }}$.

Martins Pena descreve em sua peça teatral de um ato a atuação do juiz de paz no campo $^{230}$, que poderia assumir atribuições bem diferentes do juiz de paz na cidade. No campo os seus poderes policiais e militares eram normalmente mais acentuados, inclusive os privilégios junto à Guarda Nacional - muitas vezes eram os juízes de paz que organizavam a lista de isentos para prestar o serviço militar, o que também gerava espaço para troca de favores.

Basicamente, a peça de Martins Pena começa quando Manuel João, um agricultor que cultivava mandioca e era membro da Guarda Nacional, recebe uma petição do escrivão do juiz de paz determinando que escolte ao Rio um homem recentemente recrutado para que faça parte da Armada Imperial. Manoel João fica muito irritado, pois não pode se dar ao luxo de abandonar sua granja, mas é ameaçado pelo juiz de paz de ser preso se não cumprir o determinado. A história desenrola-se a partir daí, com a descrição do ocorrido em várias sessões de conciliação realizadas pelo juiz de paz, revelando os tipos de conflitos submetidos a estes juízes, as partes litigantes, o ambiente de troca de favores em que ocorriam as sessões, tudo através de narrativa marcada por um tom sutilmente irônico.

Além de conciliações, os juízes de paz celebravam casamentos, sendo as alianças

\footnotetext{
${ }^{228}$ Muitas vezes o juiz de paz buscava promover "reforma social" através de suas conciliações. D. Manoel I já tratava da existência de "concertadores de demandas", previstos pela Ordenação e Regimento de 20.01.1519, que podiam e deviam tomar a iniciativa da conciliação com a maior amplitude, a ponto de lhes ser permitido procurarem espontaneamente os desavindos nas suas próprias residências, a fim de os persuadirem a solucionar amigavelmente os seus litígios, quer já sujeitos à apreciação dos Tribunais, quer apenas prestes a deflagrarem. Cf. SURGIK, Aloísio. A origem da Conciliação. Tese (Doutorado em Direito). Faculdade de Direito da USP, São Paulo, 1984, p. 461. Segundo Michel Debrun, a ideia de "conciliação", assim entre aspas, é aquela que pressupõe o desequilíbrio, a dissimetria dos parceiros, tanto no nível micropolítico do engenho, da fazenda, da empresa, da repartição pública, etc, como no nível macropolítico da constituição e manutenção do poder central. A "conciliação" não teria se desenvolvido para evitar brigas incertas ou custosas entre contendores de força comparável. DEBRUN, Michel. A conciliação e outras estratégias. São Paulo: Editora Brasiliense, 1983, p. 15.

${ }^{229}$ FLORY, El juez de paz cit, p. 100.

230 "Juiz de paz na roça” (1838), de Luis Carlos Martins Pena.
} 
matrimoniais acima de tudo formas de alianças político-econômicas e de ascensão social $^{231}$. Carlos Drummond de Andrade, em "A paz entre os juízes”, trata da atuação dos juízes de paz e dos casamentos arranjados nos clãs familiares ${ }^{232}$.

Segundo Caetano Lagrasta Neto, o juiz de paz poderia ter surgido como alternativa razoável na busca de um escoadouro à litigiosidade contida, pois tem como característica o juízo de conciliação e visa harmonizar as partes, evitando as demandas, que, em não sendo possível, transformam-se em contenciosas, com recursos ao juiz de direito da comarca. Mas apesar desta possibilidade de uma justiça mais próxima do povo, acabou por esquecêlas, sem qualquer preocupação de desenvolvimento, deixando de aprimorar institutos que hoje representariam a mais moderna posição processualística - os juizados de conciliação, de vizinhança, de bairro; os juizados de pequenas causas ${ }^{233}$.

As Constituições de 1934 e 1937 mantiveram a justiça de paz eletiva, com a competência que lhe desse a lei estadual, ressalvando recurso de suas decisões para a justiça togada, mas, durante toda a vigência do Estado Novo, que nunca pôs em prática o seu mecanismo representativo, os juízes de paz foram de livre nomeação do governo dos Estados. Também a Constituição de 1946 manteve a justiça de paz, cuja eletividade não foi declarada obrigatória. Foi-lhe vedado, porém, mesmo em substituição, proferir julgamentos finais ou recorríveis, para afastar os notórios inconvenientes do sistema até então vigorante ${ }^{234}$.

A atual Constituição Federal de 88 também previu "a Justiça de Paz remunerada, composta de cidadãos eleitos pelo voto direto, universal e secreto, com mandato de quatro anos e competência para, na forma da lei, celebrar casamentos, verificar, de ofício ou em

\footnotetext{
${ }^{231}$ Segundo Maria Isaura Pereira de Queiroz, o casamento no interior da parentela (tios com sobrinhas, primos com primas) era a maneira de impedir que a fortuna fosse para mãos de estranhos, ou se dividisse. $\mathrm{O}$ casamento fora da parentela poderia se dar: i. como resultado de aliança de dois grupos poderosos que passavam a ser parentes e unidos política e economicamente, podendo se elevar na hierarquia do domínio graças a essa soma de forças familiares, econômicas e políticas; ii. Como forma de ascensão social, com moço que podia ser pobre, mas cujas qualidades eram uma garantia da expansão da fortuna. QUEIROZ, $O$ mandonismo local cit., p. 192.

${ }^{232}$ ANDRADE, Carlos Drummond. A Paz entre os Juízes. In: Esquecer para Lembrar: Boitempo III. Rio de Janeiro: Sabiá, 1979, pp. 6-7.

${ }^{233}$ NETO, Caetano Lagrasta. Juizado Especial de Pequenas Causas e Direito Processual Civil Comparado. In: WATANABE, Kazuo (Org.). Juizado especial de pequenas causas: Lei 7.244, de 7 de novembro de 1984. São Paulo: Revista dos Tribunais, 1985, pp. 58-59

${ }^{234}$ LEAL, Coronelismo, enxada e voto cit, p. 205
} 
face de impugnação apresentada, o processo de habilitação e exercer atribuições conciliatórias, sem caráter jurisdicional, além de outras previstas na legislação (art. 98)”."

Investigando o contexto em que surgiu a Justiça de Paz no Brasil Império e as atribuições dos juízes de paz, quer durante o período de sua consagração liberal quer durante o declínio na fase em que restrições foram implementadas pelos conservadores, é possível notar que por trás da figura do juiz de paz está a centralidade da política judicial na constituição do Estado brasileiro, ou seja, das reformas políticas implementadas a partir de mudanças no sistema judicial ${ }^{235}$.

Segundo Thomas Flory, aqueles que governaram o Brasil consideraram os juízes como guardiões políticos do governo e representantes do poder, assim como (idealmente) representantes imparciais da lei. Enquanto os reformadores liberais acreditavam fervorosamente que o juiz local e as instituições com ele compatíveis debilitariam a autoridade central e melhorariam a administração da justiça, os conservadores, por sua vez, perseguiam metas políticas antagônicas por meio de outra reforma judicial. Assim, quaisquer que fossem suas posições sociais ou predileções ideológicas, os atores buscavam instintivamente na reforma do sistema judicial a solução de seus problemas ${ }^{236}$.

A Justiça de Paz ainda existe hoje, prevista na Constituição Federal de 88, e uma revitalização de suas funções tem sido bastante debatida no cenário atual, como uma medida de administração judicial que poderia ser explorada para reduzir a morosidade e o custo da justiça - na busca de meios autocompositivos de solução de conflitos ${ }^{237}$.

\footnotetext{
${ }^{235}$ Para Flory, o papel predominante que assumiu a oligarquia judicial no Brasil estaria também relacionado ao menor papel assumido pela Igreja e Militares, se compararmos com a atuação das corporações religiosas e militares na América Hispânica, durante a vida política do século XIX. Isso permitiu que a oligarquia judicial reinasse nos anos de 1830 de forma predominante. FLORY, El juez de paz cit, p. 318.

${ }^{236}$ Ibidem, p. 317.

${ }^{237}$ Em 24/06/2008, o Conselho Nacional de Justiça publicou recomendação aos tribunais de Justiça para que regulamentem a função de juiz de paz, escolhido por eleições diretas. Os tribunais devem encaminhar projeto de lei às Assembléias Legislativas sobre as eleições e a remuneração do cargo. A proposta de lei estadual deverá incluir as normas para a atuação dos juízes de paz como conciliadores e nas varas de família.

Esta recomendação (num. 16) foi provocada por um pedido de providências do Tribunal de Justiça do Mato Grosso do Sul, onde as nomeações para o cargo são feitas pelos juízes. Mas a maioria dos Tribunais não regulamentou a matéria (vide notícia integral em http://www.cnj.jus.br). Acesso em 20/12/2010. Por outro lado, tramita paralelamente na Câmara a Proposta de Emenda à Constituição (PEC n $\left.{ }^{0} 366 / 05\right)$, do deputado Arnaldo Faria de Sá (PTB-SP), que exige concurso público para a admissão de juízes de paz. A proposta altera a Constituição Federal, que determina a eleição desses juízes pelo voto direto, universal e secreto, para um mandato de quatro anos.
} 
Segundo Marco Antonio Lorencini, muito embora o resgate da figura do juiz de paz pela Constituição de 1988 ainda não tenha animado o resgate da tradição na sociedade, trata-se de importante instituição calcada na ideia de poder local e com raízes comunitárias e é nisso que reside o seu valor, pois a ideia de ADR contém um ingrediente comunitário que não suprime outras forças e concepções, podendo perfeitamente o juiz de paz assumir a figura contemporânea do mediador. A sua vocação comunitária não deve ser vista como dificuldade, mas sim como atributo a ser explorado ${ }^{238}$.

\subsection{Pesquisa empírica nos Programas de Mediação e Conciliação}

Por fim, antes de iniciar a análise da institucionalização da mediação nos EUA e no Brasil, é importante apresentar as escolhas e a metodologia da pesquisa empírica realizada nos programas de mediação e conciliação, e que fundamentam as posições e conclusões centrais apresentadas nos capítulos seguintes. A pesquisa empírica foi realizada nos anos de 2009 (nos EUA) e 2010 (no Brasil), tendo como objeto o desenho e o funcionamento de programas de mediação e conciliação no Judiciário. Trata-se de uma pesquisa de diagnóstico, que foi feita com base em entrevistas presenciais e preenchimento de questionários elaborados pela autora (em anexo) e compostos por perguntas distribuídas em 4 eixos temáticos:

Eixo 1. Características gerais dos programas/setores de mediação e conciliação

Eixo 2. Triagem/filtragem dos conflitos (screening process)

Eixo 3. Papéis dos atores envolvidos: i. partes; ii. advogados; iii. juízes; iv. mediadores / conciliadores; v. coordenador do programa de mediação / conciliação.

Eixo 4. Dinâmica da mediação e conciliação (procedimento e outras peculiaridades)

A escolha dos Estados e Tribunais em que foram analisados os programas de mediação e conciliação se justificou pela busca de diversidade entre os elementos comparativos, pela indicação de professores e mediadores com experiência em meios

${ }^{238}$ LORENCINI, A contribuição dos meios alternativos cit., p. 607. 
autocompositivos no Judiciário, e pela disponibilidade dos coordenadores dos programas em participar da entrevista, apresentar dados e permitir a visita ao local.

Nos EUA, os programas pesquisados apresentam diferentes níveis de regulação, centralização, volume de casos, critérios relativos à triagem, obrigatoriedade e facultatividade da mediação, o que tornou possível comparar diferentes modelos, suas fases de implementação e funcionamento.

No Brasil, também se priorizou a diversidade entre os programas, tendo sido selecionados programas pré-processuais e processuais, judiciais e comunitários, de conciliação e mediação, nas áreas cível e de família ${ }^{239}$, em $1^{\text {a }}$ e $2^{\mathrm{a}}$ instâncias, nos Fóruns Centrais e Regionais. A escolha também se pautou no tempo de existência dos programas e na disponibilidade de dados sobre o seu funcionamento.

Foram realizadas visitas a cada um desses programas, e entrevistas aos coordenadores e managers que os gerenciam - nos EUA, estes diretores trabalham nos escritórios centrais de meios de solução de conflitos (Central Office of Dispute Resolution), localizados na Suprema Corte Estadual. No Brasil, os centros ou setores de mediação e conciliação pesquisados estão situados nos Fóruns Centrais ou Regionais, junto às Varas ou a Cartórios judiciais, com exceção do Programa de Justiça Comunitária do TJDF, situado em cidades satélites do Distrito Federal (Taguatinga e Ceilândia), embora conte com uma sala de apoio no Fórum destes locais, e da Unidade Avançada de Conciliação pré-processual pesquisada na cidade de São Paulo, que fica fora do Tribunal, no bairro da Liberdade.

Após o preenchimento dos formulários em entrevistas presenciais de coordenadores e funcionários dos programas, houve o envio das respostas por email aos entrevistados

\footnotetext{
${ }^{239}$ Não foi incluída na pesquisa a mediação nas áreas trabalhista e criminal, muito embora haja interessantes iniciativas em ambas. Uma delas é a do Projeto Íntegra- Gênero e Família, idealizado e coordenado por Célia Regina Zapparolli desde 2001. O programa é voltado à mediação de conflitos, em contextos de violência e crimes de gênero e família, a partir das ações judiciais processadas pelas Leis n ${ }^{\circ} \mathrm{s}$ 9.099/1995 e 11.340/2006. Desde 2005 o Projeto tem núcleo implantado no Fórum Regional de Santana, em São Paulo, Capital. Vide maiores informações em ZAPPAROLLI, Célia Regina. Políticas Públicas de Justiça e a Mediação de Conflitos intra-familiares em contextos de crimes processados pelas leis 9099/1995 e 11.340/2006. In: SALLES, Carlos A (Org). As Grandes Transformações do Processo Civil Brasileiro. Homenagem ao Prof. Kazuo Watanabe. São Paulo: Quartier Latin, 2009, pp. 560-568.
} 
para a sua conferência ${ }^{240}$, com base na qual foram montados os quadros comparativos que estão detalhados nos itens 4.2 e 5.2 deste trabalho. Apesar de muitas das respostas terem sido também conferidas in loco através de visitas realizadas a todos os programas pesquisados, elas foram dadas a partir da percepção subjetiva dos entrevistados, considerando a sua experiência, a regulação e os objetivos de cada programa.

Os quadros comparativos são uma fotografia dos programas, mas não significam que as escolhas e modelos adotados estejam cristalizados em um desenho rígido, muito embora em alguns casos a regulação legislativa e judiciária confiram certa estabilidade ao desenho dos programas, principalmente aos mais antigos.

Também contribuiu à análise dos programas a participação da autora em treinamentos de mediadores (em Ohio e Maine) e em sessões de mediação e conciliação, no Brasil e nos EUA, na qualidade de observadora ${ }^{241}$.

Nos EUA foram escolhidos programas de mediação anexos às Cortes de quatro Estados (Court-connected programs), nos Tribunais Estaduais de Ohio (Columbus), Flórida (Tallahassee e Tampa), Maine (Portland) e Connecticut (Wethersfield e New Haven).

No Brasil, foram escolhidos programas e setores de mediação e conciliação em Tribunais de três Estados: Tribunais Estaduais de São Paulo (Fórum Central João Mendes, Fóruns Regionais de Pinheiros e de Santana), Distrito Federal (Programa de Justiça Comunitária em Taguatinga e Ceilândia) e Rio de Janeiro (Centro de Mediação de família do Fórum Central).

\footnotetext{
${ }^{240} \mathrm{O}$ único formulário que não passou por esta revisão de respostas foi o do Centro de Mediação do Fórum Central do Rio de Janeiro, tendo havido a realocação de funcionários deste Centro no decorrer da pesquisa, e a ausência de resposta ao email com a conferência do questionário. O quadro de respostas foi então preenchido com base nas entrevistas realizadas.

${ }^{241}$ A pesquisa empírica nos EUA restringiu-se à Justiça Estadual, mas durante aproximadamente 1 mês e meio (de maio a junho de 2009) observei sessões de mediações na Justiça Federal, além de audiências preliminares e gerenciamento de demandas no Distrito de Connecticut - United States District Court District of $C T$, com a juíza federal Janet Bond Arterton e a magistrate judge Margolis, o que se revelou bastante útil, pois muitos modelos e normas federais são reproduzidos na esfera estadual.
} 
No total, foram analisados dez programas de mediação e conciliação, nos EUA e no Brasil, a partir dos quatro eixos temáticos já referidos, cada um composto pelas seguintes perguntas:

Tabela 2. Eixos Temáticos das entrevistas

\begin{tabular}{|c|c|c|c|c|}
\hline EIXO 1 & EIXO 2 & EIXO 4 & \multicolumn{2}{|c|}{ EIXO 3} \\
\hline $\begin{array}{l}\text { Características } \\
\text { gerais do } \\
\text { programa }\end{array}$ & $\begin{array}{l}\text { A triagem dos } \\
\text { conflitos } \\
\text { (screening } \\
\text { process })\end{array}$ & $\begin{array}{c}\text { Dinâmica da } \\
\text { mediação: } \\
\text { procedimento e } \\
\text { outras } \\
\text { peculiaridades }\end{array}$ & $\begin{array}{l}\text { Papéis dos } \\
\text { atores } \\
\text { envolvidos } \\
\text { (advogados e } \\
\text { partes) }\end{array}$ & $\begin{array}{l}\text { Papéis dos atores } \\
\text { envolvidos (juiz, } \\
\text { mediador/ } \\
\text { conciliador e } \\
\text { coordenador do } \\
\text { programa) }\end{array}$ \\
\hline $\begin{array}{l}\text { Ano em que foi } \\
\text { implementada a } \\
\text { mediação / } \\
\text { conciliação no } \\
\text { Judiciário }\end{array}$ & $\begin{array}{l}\text { Como o caso é } \\
\text { direcionado à } \\
\text { mediação? }\end{array}$ & $\begin{array}{c}\text { A mediação } \\
\text { suspende a açãa } \\
\text { judicial em curso? }\end{array}$ & $\begin{array}{l}\text { As partes } \\
\text { precisam estar } \\
\text { assistidas por } \\
\text { advogado? }\end{array}$ & $\begin{array}{l}\text { Pode o juiz direcionar } \\
\text { o caso à mediação? }\end{array}$ \\
\hline Tipos de conflito & $\begin{array}{l}\text { Critérios ou } \\
\text { requisitos para } \\
\text { a filtragem dos } \\
\quad \text { conflitos }\end{array}$ & $\begin{array}{l}\text { Qual é a pauta, a } \\
\text { duração e a média } \\
\text { do número de } \\
\text { sessões no setor? }\end{array}$ & $\begin{array}{l}\text { Os advogados e } \\
\text { as partes } \\
\text { precisam estar } \\
\text { presentes na } \\
\text { sessão de } \\
\text { mediação? }\end{array}$ & $\begin{array}{l}\text { Como é o } \\
\text { envolvimento do juiz } \\
\text { durante a mediação? }\end{array}$ \\
\hline $\begin{array}{l}\text { Mediação } \\
\text { (obrigatória ou } \\
\text { voluntária) }\end{array}$ & $\begin{array}{l}\text { Há formulário } \\
\text { de requisição? }\end{array}$ & $\begin{array}{l}\text { É possível } \\
\text { realizar a } \\
\text { mediação por } \\
\text { telefone ou } \\
\text { email? Como as } \\
\text { partes são } \\
\text { notificadas? }\end{array}$ & $\begin{array}{c}\text { Podem as partes } \\
\text { trazer à } \\
\text { mediação outras } \\
\text { pessoas para } \\
\text { suporte } \\
\text { emocional? }\end{array}$ & $\begin{array}{l}\text { O mediador precisa } \\
\text { ser formado em } \\
\text { direito? Qual é a sua } \\
\text { formação? }\end{array}$ \\
\hline $\begin{array}{c}\text { Regulação } \\
(\text { due process })\end{array}$ & $\begin{array}{l}\text { Quando o caso } \\
\text { pode ser } \\
\text { remetido à } \\
\text { mediação? }\end{array}$ & $\begin{array}{l}\text { Há prazos para a } \\
\text { mediação? } \\
\text { Durante a sessão, } \\
\text { há normalmente } \\
\text { sessões } \\
\text { individuais com } \\
\text { as partes } \\
\text { (caucus)? }\end{array}$ & $\begin{array}{c}\text { O programa } \\
\text { coleta } \\
\text { informações se } \\
\text { é a } 1^{\mathrm{a}} \text { vez que as } \\
\text { partes se } \\
\text { submetem à } \\
\text { mediação? }\end{array}$ & $\begin{array}{l}\text { Os mediadores são } \\
\text { funcionários ou } \\
\text { contratados pela } \\
\text { Corte? }\end{array}$ \\
\hline $\begin{array}{l}\text { Estrutura do } \\
\quad \text { Setor }\end{array}$ & $\begin{array}{l}\text { Há mediação } \\
\text { sem ação } \\
\text { judicial (pre } \\
\text { suit } \\
\text { mediation)? }\end{array}$ & $\begin{array}{l}\text { Confidencialidade } \\
\text { da mediação }\end{array}$ & $\begin{array}{l}\text { São comuns nos } \\
\text { programas } \\
\text { disputas com } \\
\text { múltiplas } \\
\text { partes? E ações } \\
\text { coletivas? }\end{array}$ & $\begin{array}{l}\text { Qual é o gênero e a } \\
\text { idade média dos } \\
\text { mediadores? }\end{array}$ \\
\hline $\begin{array}{c}\text { Custos para as } \\
\text { partes }\end{array}$ & $\begin{array}{c}\text { Pode haver o } \\
\text { direcionamento } \\
\text { do conflito para } \\
\text { mediações } \\
\text { privadas? }\end{array}$ & $\begin{array}{l}\text { É possível } \\
\text { requerer } \\
\text { aprovação, } \\
\text { revisão ou } \\
\text { homologação do } \\
\text { acordo pela }\end{array}$ & $\begin{array}{l}\text { O programa } \\
\text { oferece algum } \\
\text { tratamento } \\
\text { diferenciado } \\
\text { quando há } \\
\text { desnível de }\end{array}$ & $\begin{array}{c}\text { Há algum treinamento } \\
\text { ou capacitação } \\
\text { necessária? }\end{array}$ \\
\hline
\end{tabular}




\begin{tabular}{|c|c|c|c|}
\hline & Corte? & $\begin{array}{c}\text { poder entre as } \\
\text { partes? }\end{array}$ & \\
\hline $\begin{array}{c}\text { Recursos/Fundos } \\
\text { destinados ao } \\
\text { programa }\end{array}$ & $\begin{array}{l}\text { É possível } \\
\text { recorrer do } \\
\text { acordo? E } \\
\text { submetê-lo à nova } \\
\text { mediação? }\end{array}$ & & $\begin{array}{l}\text { Há certificação de } \\
\text { mediadores? }\end{array}$ \\
\hline $\begin{array}{c}\text { Volume de casos } \\
\text { - dimensão do } \\
\text { programa }\end{array}$ & $\begin{array}{l}\text { Há controle sobre } \\
\text { repeat players? }\end{array}$ & & $\begin{array}{c}\text { Como se dá a escolha } \\
\text { dos mediadores? Há } \\
\text { alguma lista nas } \\
\text { Cortes? }\end{array}$ \\
\hline \multirow[t]{7}{*}{$\begin{array}{c}\text { Há outros ADRs } \\
\text { oferecidos pelo } \\
\text { Programa? }\end{array}$} & $\begin{array}{c}\text { Há alguma } \\
\text { pesquisa de } \\
\text { opinião após a } \\
\text { mediação sobre a } \\
\text { satisfação das } \\
\text { partes com o } \\
\text { procedimento e } \\
\text { resultado? }\end{array}$ & & $\begin{array}{l}\text { É possível mudar o } \\
\text { mediador no curso do } \\
\text { procedimento? }\end{array}$ \\
\hline & $\begin{array}{l}\text { Características do } \\
\text { local em que são } \\
\text { realizadas as } \\
\text { sessões de } \\
\text { mediação } \\
\end{array}$ & & $\begin{array}{c}\text { O mediador / } \\
\text { conciliador pode ser } \\
\text { um especialista na } \\
\text { matéria do conflito? }\end{array}$ \\
\hline & & & $\begin{array}{c}\text { Mediador possui } \\
\text { poderes } \\
\text { discricionários } \\
\text { (contempt of Power)? }\end{array}$ \\
\hline & & & $\begin{array}{c}\text { Mediador pode relatar } \\
\text { ao Juiz algo sobre a } \\
\text { mediação? }\end{array}$ \\
\hline & & & $\begin{array}{c}\text { O programa segue } \\
\text { regras sobre ética e } \\
\text { responsabilidade dos } \\
\text { mediadores? }\end{array}$ \\
\hline & & & $\begin{array}{c}\text { Há um } \\
\text { administrador/coord. } \\
\text { do programa? }\end{array}$ \\
\hline & & & $\begin{array}{l}\text { Quais são as principais } \\
\text { atividades do } \\
\text { administrador? Qual é } \\
\text { a formação do } \\
\text { administrador? }\end{array}$ \\
\hline
\end{tabular}

O objetivo da pesquisa empírica foi diagnosticar, descrever e comparar as escolhas feitas entre os programas. Não se objetivou a avaliação ou indicação de um melhor programa, nem a mera transposição da experiência norte-americana ao Brasil, pois em cada local há peculiaridades e racionalidades específicas a serem observadas. Mesmo entre os programas de um mesmo Estado há diferenças, e o objetivo desta pesquisa é contrastar 
para melhor conhecer, e não contrastar para escolher, pois as escolhas de modelos e programas devem ser feitas em outro foro.

Alguns cuidados são necessários para a análise comparativa entre diferentes países e sistemas. Robert Kagan diferencia os sistemas de common law e o de civil law ao atribuir ao primeiro a ideia de lawyer domination e ao segundo a de judge domination. No caso de produção de provas, por exemplo, enquanto no sistema de civil law os juízes coordenam a fase de instrução probatória, no sistema de common law são os advogados que conduzem o discovery e também as negociações que servem de base para barganhar um bom acordo, sendo reduzidos os poderes instrutórios do juiz, ainda que exerçam uma fisscalização importante nesta fase ${ }^{242}$.

No sistema adversarial norte-americano os advogados tem mais liberdade criativa na produção de provas, formulação de argumentos legais e influência das decisões judiciais. Trata-se de um exercício profissional agressivamente empresarial, e que também influencia políticas públicas e práticas institucionais. O Judiciário é selecionado politicamente e é mais imprevisível, enquanto a administração do governo é descentralizada e revela-se mais responsiva às pressões políticas ${ }^{243}$.

Kagan reflete sobre a distinção entre esses dois sistemas em termos de: policymaking, policy implementation e dispute resolution, tendo em vista os modelos dominados pelos advogados ou juízes ${ }^{244}$.

\footnotetext{
${ }^{242}$ In the United States, the attorneys of the parties conduct the settlement as well as the bargaining, and the information gathered in pretrial discovery often becomes the basis for a settlement. Cf. KAGAN, Robert A. Adversarial legalism: the American way of law, Cambridge: Harvard University Press, 2003, p. 108.

${ }^{243}$ In comparison with most other economically advanced democracies, the national government in the United States shares more power with states and municipalities, and at every level of government chief executives share more power with legislatures, legislative party leaders with subcommittee chairs and backbenchers, administrative agencies with judges, and judges with lawyers and juries. Ibidem, pp. ix, 7, 15.

${ }^{244} \mathrm{Na}$ Europa Ocidental (que representa o sistema de civil law) prevalece o método de governança e de solução de conflitos baseado na administração burocrática, relacionado ao judge-dominated style of litigation. Nos EUA, por outro lado, é o sistema adversarial que predomina, analisando Kagan os seus aspectos positivos e negativos a partir de quarto vertentes: 1. modelo de adjudicação dominado pelo litigante; 2. um Judiciário selecionado politicamente e com poderes para reverter decisões do Legislativo e do Executivo; 3. um exercício da advocacia altamente empresarial; 4. Julgamento pelo júri. Em balanço dos aspectos positivos e negativos destas escolhas no sistema legal norte-americano, considera Kagan que ao mesmo tempo em que o sistema legal norte-americano é mais aberto a novas formas de demandas por justiça e aos movimentos políticos, sendo o Judiciário particularmente flexível e criativo, isso faz com que o sistema adversarial torne-se claramente ineficiente, complexo, caro, punitivo, e conte com um imprevisível método de governança e de solução de disputas. Ibidem, pp. 3-6.
} 
Comparando esses sistemas, Hazard e Taruffo também reconhecem que enquanto no sistema de civil law há uma confiança exacerbada na figura do Juiz, presumindo-se que a sua interpretação irá objetivamente determinar a verdade, conhecendo a lei e orquestrando a produção de provas para a prolação de uma sentença, no sistema de common law, por sua vez, esta confiança é atribuída em grande parte ao advogado (adversary system), inclusive na escolha da técnica mais adequada para o gerenciamento do conflito, e na condução e manejo da mesma ${ }^{245}$. O formalismo e regime preclusivo do sistema de civil law também se contrapõem à flexibilidade processual e gerencial no sistema de common law nos EUA. Estas diferenças estão de certa forma refletidas na pesquisa empírica realizada, nas características e funcionamento de cada programa de mediação pesquisado.

\footnotetext{
${ }^{245}$ Sem aqui propor uma visão estereotipada das funções do juiz e das partes nestes sistemas, mas apenas parâmetros de análise comparativa. Cf. HAZARD JR., Geoffrey C.; TARUFFO, Michele. American Civil Procedure: an introduction. New Haven and London: Yale University press, 1993, pp. 20-21.
} 


\section{MEDIAÇÃO NO JUDICIÁRIO NORTE-AMERICANO}

\subsection{Medidas voltadas à institucionalização da mediação}

Este capítulo trata de medidas concretas voltadas à institucionalização da mediação nas Cortes norte-americanas. Isso se deu em diferentes esferas: legislativa, judicial e administrativa, em nível estadual e federal, constatando-se que desde 1970 vem sendo construído um trajeto rumo à institucionalização da mediação, através de projetos-piloto, experimentações, gerenciamento de processos, programas e iniciativas que são retratados nos itens a seguir, culminando com a pesquisa empírica de quatro diferentes programas de mediação, analisados em quadro comparativo.

\section{a) Sistema Multiportas de solução de conflitos: o advento dos Court-connected programs nos EUA}

A primeira vez que se referiu ao sistema multiportas de solução de conflitos (Multidoor Courthouse) foi na Pound Conference, em 1976, em discurso de Frank Sander depois transcrito e publicado no artigo "Varieties of Dispute Processing"246. Ao invés de uma única porta direcionada ao Judiciário, um centro de solução de conflitos localizado na Corte poderia oferecer várias portas através das quais os indivíduos acessariam diferentes processos (mediação, arbitragem, factfinding, dentre outros).

Segundo Sander, este centro de solução de conflitos se destinaria não apenas aos assuntos já tratados pelas Cortes, mas também a questões ainda não ventiladas junto ao Judiciário, demandas que estariam suprimidas e que poderiam ver nesses novos caminhos uma forma de expressão. Se isso seria bom ou ruim no futuro, era difícil dizer, mas o autor já visualizava um trade-off inevitável: ao melhorar o esquema de solução de conflitos,

\footnotetext{
${ }^{246}$ SANDER, Frank. Varieties of Dispute Processing cit., pp. 65-87.
} 
aumentar-se-ia o número de disputas a serem processadas, enfrentando uma litigiosidade antes contida ${ }^{247}$.

A partir do sistema multiportas de solução de conflitos, Sander analisou diferentes processos na tentativa de criar uma taxonomia que ajudasse a pensar quais são as portas apropriadas a cada tipo de disputa. No momento da Pound Conference, em 1976, ele previa que por volta do ano 2000 seriam criados esses Centros de Solução de conflitos nas Cortes, passando as partes por um processo de triagem dos conflitos conduzido por um funcionário do Tribunal (screening clerk) que os direcionaria para o processo (ou sequência de processos) mais apropriado ao tipo de caso.

De acordo com este autor, ao procurar o Judiciário as partes passariam antes por uma antessala deste Centro de solução de conflitos em que escolheriam uma das portas para ingressar, com a ajuda do screening clerk nesta triagem do conflito e opção diante de distintas formas de composição do conflito. As diferentes portas levariam aos seguintes processos e salas:

Screening clerk Room 1

Mediation Room 2

Arbitration Room 3

Fact finding Room 4

Malpractice Screening Panel Room 5

Superior Court Room 6

Ombudsman Room 7

Aparecia, desde esse primeiro momento, uma preocupação em relação aos critérios para direcionar os conflitos a cada uma destas portas (processo de filtragem ou triagem), e Sander reconhecia o papel de vários atores neste momento: do Judiciário, ao decidir quais

\footnotetext{
${ }^{247}$ SANDER, Varieties of Dispute cit., pp. 67-68. No original: (...) not only to divert some matters now handled by the Courts into other processes but also to make available those processes for grievances that are presently not being aired at all. (...) By establishing new dispute resolution mechanisms, or improving existing ones, we may be encouraging the ventilation of grievances that are now being suppressed. Whether that will be good (in terms of supplying a constructive outlet for suppressed anger and frustration) or whether it will simply waste scarce societal resources (by validating grievances that might otherwise have remained dormant) we do not know. The important thing to note is that there is a clear trade-off: the price of an improved scheme of dispute processing may well be a vast increase in the number of disputes being processed.
} 
casos precisam ser encaminhados a uma forma adequada de solução de conflitos; do Legislativo, criando processos adequados de solução de disputas, em consonância com os direitos materiais; e mesmo de instituições como presídios, escolas e hospitais, que deveriam internamente estabelecer seus próprios processos de solução de disputas ${ }^{248}$.

Esses critérios deveriam levar em consideração a natureza do conflito, a relação entre as partes (continuada ou pontual), os custos da demanda, a celeridade da decisão, dentre outros fatores que são analisados no Capítulo 6 deste trabalho, que trata dos mecanismos de filtragem dos conflitos.

O ano de 2000, que era apenas um horizonte próximo quando Sander escreveu este primeiro artigo sobre o sistema multiportas, já passou e muitos avanços podem ser observados, embora com algumas dificuldades e obstáculos de percurso.

Em março de 2008, Sander concedeu uma interessante entrevista à Mariana Crespo, relembrando a força tarefa que se constituiu para a implementação das propostas da Roscoe Pound Conference, e quais atores estavam envolvidos neste projeto. Em suas palavras ${ }^{249}$ :

Algo específico que aconteceu foi que no outono de 1976 Jimmy Carter foi eleito
presidente dos EUA. Ele apontou Griffin Bell como o Procurador Geral dos
EUA. Bell comentou o artigo que escrevi sobre sistema multiportas para a Pound
Conference em 1976, e ele ficou instigado com o que ouviu e aprendeu nesta
Conferência. Então, ele criou um gabinete especial no Departamento de Justiça
voltado para a melhora na Administração da Justiça. Além disso, as lideranças da
Pound Conference criaram uma força tarefa para analisar as ideias apresentadas e
debatidas e como elas poderiam ser levadas adiante e implementadas. O Griffin
Bell foi a cabeça disso tudo.
Mas houve também outras influências. A Associação de Advogados dos EUA
abraçou a ideia e também criou um comitê especial, inicialmente chamado
Comitê Especial sobre a Resolução de Disputas Menores, que era uma
denominação estranha, e depois se tornou o Comitê sobre Solução de Disputas.
Em 1993 , ele se tornou a Seção de Solução de Disputas, com hoje mais de
17.000 membros. A Associação de advogados abraçou a causa. Ela organizou
uma conferência nacional todos os anos que é bastante popular nesta área; criou
um jornal chamado Dispute Resolution Magazine, e várias coisas estão
acontecendo.
Há também uma legislação federal e estadual sobre esta matéria. Uma lei
interessante que existe em alguns Estados é a que determina que os advogados

248 A Court might decide of its own to refer a certain type of problem to a more suitable tribunal. Or a legislature might, in framing certain substantive rights, build an appropriate dispute resolution process. Institutions such as prisons, schools, or mental hospitals also could get into the act by establishing indigenous dispute resolution processes. Cf. SANDER, Varieties of Dispute cit., p. 84.

${ }^{249}$ Entrevista de Frank Sander concedida à Mariana Hernandez Crespo, diretora executiva da University of St. Thomas International ADR Research Network, cuja transcrição integral está disponível em http://papers.ssrn.com/sol3/papers.cfm?abstract_id=1265221. Acesso em 20/12/2010. 
têm o dever ético de informar aos seus clientes sobre as diferentes formas de solução de disputas. Assim, quando você vai a um advogado nestes Estados como Massachusetts, Colorado e Nova Jersey, dentre outros - o advogado deve considerar o cenário geral do conflito, do mesmo jeito que faria um médico clínico geral em relação ao paciente com alguma doença. Você diz: "meu estômago dói", e o médico não deve dizer "bem, deixe-me pegar o bisturi e vamos operar". Os médicos devem dar opções ao paciente: "você pode tomar remédios, você pode não fazer nada sobre isso, você pode se submeter a uma cirurgia". Então, os advogados precisam fazer a mesma coisa com as disputas, e isso os leva naturalmente a considerar e explorar diferentes opções de disputas. E, claro, os advogados precisam aprender a agir dessa forma. A educação dos advogados é uma consequência deste tipo de obrigação ${ }^{250}$.

\section{O papel dos advogados foi bastante ressaltado, e a Associação de Advogados chegou} inclusive a financiar projetos-piloto de sistema multiportas no Judiciário:

(...) Uma das muitas coisas que a Associação dos advogados fez foi, quando o Comitê de Solução de Disputas ganhou algum dinheiro, organizar e patrocinar um projeto piloto do sistema multiportas em três lugares: Tulsa, Oklahoma; Houston, Texas; and Washington, D.C.

Embora nem todos eles tenham sido bem sucedidos e sobrevivido, o programa multiportas de Washington [the D.C. Superior Court's Multi-Door Dispute Resolution Division] é hoje um dos mais ativos e impressionantes programas.

Então, isso foi uma experimentação útil que mostrou o que fazer e o que não fazer, absolutamente ${ }^{251}$.

${ }^{250}$ Tradução livre. No original: Well, I think one specific thing that happened is that in the fall of 1976 Jimmy Carter was elected U.S. president. He appointed Griffin Bell as Attorney General of the United States. [Bell] had commented on my paper at the [1976] Pound Conference, and he was very intrigued by what he learned there. So, he set up a special division in the Department of Justice called the Office for Improvements in the Administration of Justice. Then, the Pound Conference leaders created a follow-up taskforce to look at what ideas were thrown out there [at the conference], and how they could be advanced and implemented, and Griffin Bell was the head of that.

But, there were many other influences. The American Bar Association embraced this idea and set up a special committee initially called the Special Committee on the Resolution of Minor Disputes, which was an odd name, but it gradually became the Committee on Dispute Resolution. Then in 1993 it became the ABA's Section of Dispute Resolution, which now has 17,000 members. So, the ABA has embraced this. They give a national conference every spring that is very popular in the field. They have put out a journal called Dispute Resolution Magazine, so there have been lots of things that have happened. There also has been state and federal legislation on the subject.

One interesting law that exists in a number of states is that lawyers have an ethical duty to apprise clients of different forms of dispute resolution for their cases. So when you come to a lawyer in those states-like Massachusetts, Colorado and New Jersey, and a number of other states -you have to canvas with a client, just the way a doctor ought to do if you come in with some ailment.

You say, "My stomach hurts," and the doctor does not say, "Well, let me get out my scalpel and operate." [Doctors] have to tell you your options: "You can take drugs, you can do nothing about it, you can have an operation." So, lawyers ought to be doing the same thing with disputes, and that naturally leads to greater exploration of dispute options. And of course, then the lawyers have to be educated. That is one consequence of that kind of obligation.

${ }^{251}$ Tradução livre. No original: One of the many things the ABA did is when its Dispute Resolution Committee got some money, it set up a pilot project with multi-door courthouses in three places: Tulsa, Oklahoma; Houston, Texas; and Washington, D.C. And while not all of them have survived, the Washington, D.C. multidoor courthouse [the D.C. Superior Court's Multi-Door Dispute Resolution Division] is now a very active and impressive one. So, this was a useful experiment that showed what to do and what not to do, absolutely. 
A previsão de Sander durante a Pound Conference, em 1976, sobre o advento de Centros de Solução de conflitos no Judiciário, de certa forma se verificou anos depois, com a expansão de programas de solução de conflitos anexos às Cortes em vários Estados norte-americanos. A pesquisa empírica deste trabalho foi conduzida junto aos Diretores de Centros de Mediação em quatro Cortes Estaduais norte-americanas, conforme se verá a seguir no item 4.2 deste capítulo.

Um breve histórico do passo a passo seguido desde a Pound Conference até a implementação do sistema multiportas nos EUA é retratado também por Goldberg, Sander, Rogers e Cole, a partir dos marcos centrais que são distribuídos em três décadas.

A década de 1970 foi marcada por um grande interesse em relação aos chamados meios alternativos de solução de conflitos, em substituição à litigância judicial. Como narrado acima, em 1976, na Pound Conference, renomados juristas e advogados expressaram suas preocupações sobre os custos e o tempo cada vez maiores para que as partes tivessem acesso ao Judiciário. Uma força tarefa foi mobilizada após esta conferência, estimulada pela visão de Frank Sander de que a Corte deve ser um centro de solução de conflitos aonde a parte chega com o seu problema, e, passando por uma triagem, é direcionada ao processo mais adequado ao seu tipo de caso. Foram investidos recursos públicos em projetos piloto de mediação e arbitragem, com o apoio da Associação dos Advogados ao sistema multiportas.

Em 1980, ressaltam estes mesmos autores, a advocacia começou a se familiarizar com os meios alternativos. A indústria de seguros passou a pesquisar formas de se reduzir os custos de litigância para as partes, e teve início certa medida de institucionalização de práticas de solução de conflitos alternativas ao Judiciário no mundo dos negócios.

Já no final dos anos 1990, o foco mudou da experimentação e dos projetos piloto para a efetiva institucionalização dos meios alternativos de solução de conflitos, e isso se deu principalmente no âmbito do Judiciário. No Alternative Dispute Resolution Act, de 1998, por exemplo, o Congresso determinou que toda a Corte Federal nos EUA estabelecesse seu próprio programa de ADR, através de regras locais, incentivando os litigantes a considerarem e utilizarem os meios alternativos como uma forma de composição dos conflitos. Essa experiência também se replicou nas Cortes Estaduais. 
Tanto as Cortes passaram a oferecer mais esses serviços, como as partes passaram a demandá-los mais de seus advogados. Pressões destes dois lados fizeram com que os operadores do direito tivessem que aprender a utilizar estas novas ferramentas para lidar com o maior número e complexidade de $\operatorname{conflitos}^{252}$.

Com o objetivo de debater os principais resultados e desafios que vinham sendo enfrentados pelos Court Connected Programs, em abril de 1991 foi organizada nos EUA a "National Conference on Emerging ADR issues in the State and Federal Courts", que teve como foco o relato de experiências em meios alternativos de solução de conflitos vivenciadas até então no ambiente do Judiciário. Este evento, organizado pela Escola de Direito de Harvard, pela American Bar Association e The Center for Public Resource/CPR Legal Program, teve painéis que abordaram os seguintes temas: meios alternativos de solução de conflitos e litígios de massa; obrigatoriedade vs. não obrigatoriedade de programas de meios alternativos de solução de conflitos; institucionalização dos meios alternativos de solução de conflitos no Judiciário; perspectivas dos advogados e dos clientes sobre os programas de meios alternativos de solução de conflitos no Judiciário; casos envolvendo políticas públicas: a promessa da mediação; e avaliação dos programas de meios alternativos de solução de $\operatorname{conflitos}^{253}$.

O evento ocorreu logo após a promulgação do Civil Justice Reform Act de 1990, que requeria que todas as Cortes Federais no país implementassem planos de redução de custos e de morosidade na prestação jurisdicional, o que incluía a consideração dos ADRs nesses planos, e contou com a participação de 170 juízes, servidores de diferentes Tribunais, advogados, professores, pesquisadores e representantes do Governo. Por mais que existissem diferentes experiências e iniciativas em meios alternativos no Judiciário, faltava ainda uma estratégia que assegurasse o bom funcionamento desses métodos, assim como dados empíricos que embasassem as críticas e proposições efetuadas. Este evento, através de painéis de discussões e conferências, buscou dar uma contribuição nesse sentido $^{254}$.

${ }^{252}$ Cf. GOLDBERG, Stephen; SANDER, Frank; ROGERS, Nancy; COLE, Sarah. Dispute resolution: negotiation, mediation and other processes. $4^{\text {th }}$ ed, 2003, New York: Aspen Publishers, pp. 7-9.

${ }^{253}$ Cf. SANDER, Emerging ADR Issues cit., pp. 1-5.

254 No prefácio da publicação dos debates transcritos e artigos apresentados no evento, os organizadores reconhecem que: Although the 80's were marked by extraordinary experimentation, what has been less clear are what strategies work best for performing particular tasks and for assuring the integrity, impartiality, and commitment to justice of these efforts. The burgeoning literature in the are reveals many more questions than 
No painel referente à institucionalização dos meios alternativos de solução de conflitos no Judiciário, por exemplo, foram tratadas as seguintes questões: i. as consequências do Reform Act de 1990, que fez com que as Cortes Federais passassem a enfrentar questões políticas e processuais relacionadas ao desenho dos programas de meios de solução de conflitos; ii. os porquês de se institucionalizar programas de meios alternativos no Judiciário; iii. a importância de se conhecer e obter informações dos principais atores envolvidos, de experimentações e iniciativas que garantam suporte aos programas, mas que não dependam de iniciativas isoladas de apenas alguns indivíduos; iv. mediação deve ser indicada pelo juiz ou requerida pelas partes? Deve ser obrigatória ou facultativa? A obrigatoriedade estaria relacionada à submissão ao processo de mediação (come to the table), e não à obtenção de um acordo, sendo importante à adesão inicial das partes ao programa; v. importância de destinação de orçamento e recursos ao programa (funding), assim como investimentos em treinamento, avaliação e monitoramento dos mesmos; vi. importância de ter um quadro qualificado de mediadores, sejam funcionários da Corte ou mediadores privados, de seu reconhecimento e remuneração ao prestar serviço ao Tribunal, devendo a atividade pro bono ser limitada.

Traçado esse histórico em linhas gerais, passa-se para a análise da regulamentação da mediação nos EUA e sua relação com o gerenciamento do caso pelo juiz e pelos seus auxiliares.

\section{b) Regulamentação dos meios alternativos de solução de conflitos}

Em termos de regulamentação da mediação, uma das primeiras alterações legislativas que merece destaque se deu em 1985 com a emenda ao artigo 16 das regras processuais (Federal Rules of Civil Procedure), que trata da audiência preliminar e gerenciamento da demanda (pretrial conferences, scheduling e management), autorizando o juiz a requerer a presença das partes nesta audiência (com a ressalva de que esta presença

answers and the lack of empirical studies has frustrated ADR proponents and critics alike. To answer some of the outstanding questions and respond to the increasing pressures on the courts to find sound alternative approaches, the co-sponsors commissioned papers and mounted panel discussions to Begin to provide some of the critical organization, analysis, and evaluation needed of the experimentation already produced. Cf. SANDER, Emerging ADR Issues cit., 1991, pp. iv-v. 
não é necessariamente física, realizando-se algumas audiências por telefone - conference call) e incluindo, dentre os diversos propósitos desta audiência, a facilitação do acordo.

Em 1990, foi aprovado o Civil Justice Reform Act que demandava que as Cortes Federais (District Courts) desenvolvessem planos para redução de custos e demora dos processos judiciais, com ênfase no gerenciamento da demanda, monitoramento da fase instrutória, dentre outras medidas que assegurassem uma resolução mais expedita e menos custosa do processo.

Em 1998, como já mencionado no item acima, entrou em vigor o Alternative Dispute Resolution Act (ADR Act), que reconheceu a importância dos meios alternativos de solução de conflitos como parte da política nacional de administração judicial, além de requerer que cada District Court desenvolvesse e implementasse o seu próprio programa de meios alternativos de solução de conflitos ${ }^{255}$.

De acordo com o ADR Act, as District Courts deveriam contratar funcionário com experiência em meios alternativos para implementar e administrar os programas de solução de conflitos, estando o Federal Judicial Center ${ }^{256}$ e o Administrative Office of the United States Courts autorizados a assistirem estes programas e proverem o suporte necessário ao seu funcionamento.

Outro texto legislativo relevante foi o Uniform Mediation Act, de 2001, que teve como um dos seus principais objetivos a uniformização da regulação da mediação nos Estados. O marco legal bem mais antigo da Federal Arbitration Act, de 1925, também

\footnotetext{
${ }^{255}$ A seção 651 do ADR Act estabelece no item "b" que: Each United States district court shall authorize, by local rule adopted under section 2071(a), the use of alternative dispute resolution processes in all civil actions, including adversary proceeding in bankruptcy, in accordance with this chapter, except that the use of arbitration may be authorized only as provided in section 654. Each United States district court shall devise and implement its own alternative dispute resolution program, by local rule adopted under section 2071(a), to encourage and promote the use of alternative dispute resolution in its district.

${ }^{256}$ The Federal Judicial Center is the research and education agency of the federal judicial system. It was established by Congress in 1967 (28 U.S.C. \$\$ 620-629), on the recommendation of the Judicial Conference of the United States. The many specific statutory duties of the Center and its Board fall into a few broad categories: $\boldsymbol{i}$. conducting and promoting orientation and continuing education and training for federal judges, court employees, and others; $i$. developing recommendations about the operation and study of the federal courts; iii. conducting and promoting research on federal judicial procedures, court operations, and history. By statute, the Chief Justice of the United States chairs the Center's Board, which also includes the director of the Administrative Office of the U.S. Courts and seven judges elected by the Judicial Conference. Mais informações estão disponíveis em http://www.fjc.gov/. Acesso em 20/12/2010.
} 
assumiu um importante papel regulatório dos meios alternativos de solução de conflitos, no caso de arbitragem.

Como consequência dessas alterações legislativas, e visando enfrentar os elevados custos e demora na prestação jurisdicional, as Cortes passaram a incluir ou reforçar em sua agenda iniciativas relacionadas à implementação de programas de meios alternativos de solução de conflitos, como formas de melhorar a administração da justiça. As Cortes Federais (District Courts) tomaram a dianteira neste movimento, pois a legislação criavalhes obrigações, e foram seguidas e tidas como modelo pelas Cortes Estaduais.

A District Court de Connecticut é um bom exemplo desse movimento de adaptação e implementação de programas de meios alternativos encabeçado pelas Cortes Federais. Visando atender ao estipulado pelo ADR Act de 1998, criou um Comitê para revisar os programas de solução de conflitos já existentes, a maioria destes relacionada à atuação de special masters (regra 53 das Regras Federais de Processo Civil), e propor novos programas que atendessem aos objetivos dessa legislação.

Além da disposição estabelecida nas Regras Federais de Processo Civil, a figura do special master também é prevista nas regras locais de vários Tribunais, e a função que exerce no processo pode variar bastante, atuando como terceiro avaliador, como mediador, como perito técnico, funções que podem ser exercidas em ações coletivas, em casos de indenização de difícil liquidação, mediações complexas, no desenho de solução de conflitos, dentre outros ${ }^{257}$. Trata-se de um terceiro que não pode ter relação com as partes ou com o Juiz, sendo normalmente advogado, muito embora esta não seja uma exigência legal $^{258}$.

\footnotetext{
${ }^{257}$ No caso do ataque terrorista de 11 de setembro nos EUA, o procurador geral apontou o advogado Kenneth Feinberg como special master para supervisionar o fundo de indenizações de 11 bilhões destinados às vitimas do acidente. Sobre a administração do fundo constituído para o acidente de 11 de setembro, vide ACKERMAN, Robert M., The September 11th Victim Compensation Fund: An Effective Administrative Response to a National Tragedy, Harvard Negotiation Law Review, vol. 10, 2005, pp. 135-229.

258 Acerca das funções do special master, vide Local Rules of Civil Procedure do Distrito de Connecticut, que foram adotadas em Janeiro de 2004: Rule 53. Special Masters. (a) Creation of Panel of Special Masters - the active Judges of the District may appoint from among the members of the bar of this Court a panel of special masters for each seat of Court for the purpose of settlement of cases or for any other proper purpose determined by the Judge to whom a particular case has been assigned. (b) Appointment of a Master - the parties to a civil action may stipulate in writing to, or the judge to whom the case has been assigned may order, the appointment of a master to report upon a particular issues in the case including the holding of status or settlement conference. The stipulation may suggest the master, in which case the Judge may appoint
} 
Na Corte Federal de Connecticut, a atuação dos special masters teve início informalmente em 1965, pela iniciativa de um dos juízes da District Court em montar uma lista de advogados que se disponibilizassem a mediar alguns casos cíveis. Esta medida foi oficializada em 1985 pelo Presidente da Corte e hoje os juízes federais em Connecticut possuem uma lista de aproximadamente 300 special masters, com especialização em diferentes áreas.

A atuação dos special masters pode ser indicada pelo juiz ou requerida consensualmente pelas partes. Em Connecticut, as audiências com os special masters são realizadas fora da Corte e ao final é apresentado ao juiz um relatório de atividades, sobre o qual as partes se manifestam. A remuneração é fixada pelo juiz, a título de custos do processo, e o valor depende das atividades realizadas. No caso de mediações e tentativas de acordo, por exemplo, a atividade é geralmente pro bono, enquanto a atuação dos special masters em demandas coletivas é remunerada.

Em termos de legislação local, as regras de processo civil de Connecticut (local rules of civil procedure) preveem conferências destinadas à tentativa de acordo (settlement conferences) após o fechamento da fase instrutória (discovery), e a obrigatoriedade de se discutir as vantagens e desvantagens do acordo no momento de planejamento da demanda (case management). Estas conferências podem ser conduzidas pelo juiz, pelo magistrate judge (tipo de juiz que será analisado a seguir), por um parajudicial officer ou mesmo pelo special master.

Além das conferências de acordo e da atuação dos special masters, os casos podem ser direcionados a outros meios de solução de conflitos em qualquer fase da demanda processual, por sugestão do juiz ou iniciativa das partes. As partes devem preencher formulário (stipulation for reference to $A D R$ ) em que esclarecem a técnica compositiva que estão buscando, quem irá provê-la, o procedimento, efeitos da decisão (vinculantes ou não), datas e cronograma, bem como seu reflexo na agenda já fixada durante o gerenciamento, dentre outras questões.

the person named. A master shall not be appointed to any particular case unless he or she consents to such appointment (...). 
Ainda que importantes medidas tenham sido adotadas para colocar em prática as modificações legislativas mencionadas, ainda é necessário que essas alterações sejam acompanhadas de uma maior divulgação e esclarecimento sobre as formas extrajudiciais de solução de conflitos voltadas aos operadores e usuários do sistema de justiça. Isso pode se dar no ambiente educacional e formativo das escolas, universidades, cursos e capacitações, estimulando as pessoas a considerarem os mecanismos extrajudiciais e autocompositivos no momento de solucionar seus litígios.

\section{c) Mediação e gerenciamento do processo}

Muito se fala do gerenciamento do processo pelos juízes norte-americanos, o chamado case management, havendo uma relação importante entre este gerenciamento e a utilização dos meios alternativos de solução de conflitos.

Logo no início da demanda judicial, as partes precisam apresentar ao juiz um relatório de planejamento da demanda, que está previsto nas regras 16(b)(1)(a) e 26(f) das Federal Rules of Civil Procedure (FRCP).

Especificamente na Corte Federal de Connecticut, há um formulário criado pelas regras locais de processo civil destinado a este planejamento (Report of Parties' planning meeting), em que as partes definem uma série de questões essenciais ao gerenciamento do caso, dentre elas a tentativa de mediação ou a adoção de outra forma de solução de conflito alternativa ao Judiciário e um plano de gerenciamento (case management plan). Neste relatório são abordados os seguintes temas:

1. Certification: os advogados devem certificar-se de que seus clientes estão de acordo com a natureza e os fundamentos das questões trazidas a juízo, bem como com a possibilidade de solução do caso via acordo. Os clientes devem ter uma cópia deste plano.

2. Jurisdiction: análise da jurisdição, que pode ser definida por matéria (subject matter jurisdiction) ou pessoa (personal jurisdiction).

3. Brief description of the case: breve descrição da inicial, contestação e demais manifestações das partes e de terceiros.

4. Statement of Undisputed Facts: parcela incontroversa dos fatos.

5. Case management plan (plano de gerenciamento), contendo:

A) Standing order on scheduling in civil cases: possibilidade de as partes requerem alteração dos prazos fixados inicialmente; 
B) Scheduling Conference with the Court: possibilidade de as partes requererem uma audiência preliminar (pretrial conference) antes da scheduling order prevista na regra $16 \mathrm{~b}$ (FRCP)

C) Early Settlement Conference: partes se manifestam sobre a possibilidade de acordo antes do início da fase instrutória, e requerem ou não uma audiência com este fim, indicando se a preferem com o juiz da causa, o magistrate judge, o special master ou o parajudicial officer.

D) as partes podem requerer que a causa seja direcionada para uma das formas alternativas de solução de conflitos;

E) Litisconsórcio, intervenção de terceiros e emenda dos pedidos

F) Discovery: indicação das principais questões de fato que serão objeto de prova, os prazos, levantamento de custos dentre outras questões relativas a esta fase de produção de provas.

G) Dispositive motions: requerimentos incidentais apresentados pelas partes para análise do juiz antes do julgamento (trial), como em relação ao julgamento antecipado da lide (summary judgement), ao indeferimento da demanda (motion to dismiss), dentre outros.

H) Joint Trial Memorandum: memorando conjunto das partes que antecede ao Julgamento da Causa (trial)

6. Trial readiness - estabelecimento da data em que o caso estará pronto para ir a julgamento.

Além de apresentarem este relatório, há uma audiência destinada à previsão e agendamento das fases do procedimento (scheduling conference), que pode ser realizada pelo Juiz ou pelo Magistrate Judge, quando autorizado pela regra processual local. Ela ocorre logo após a fase postulatória, no prazo estabelecido em lei, e se encerra com uma decisão do juiz acerca deste planejamento (scheduling order $^{259}$ ), que deve estabelecer obrigatoriamente os prazos limites para que terceiros possam intervir no processo, para que as partes possam alterar o pedido e para a complementação da produção de provas, com a

${ }^{259}$ Este planejamento (scheduling) está previsto na regra 16(b) das FRCP, que assim o disciplina:

(1) Scheduling Order.

Except in categories of actions exempted by local rule, the district judge - or a magistrate judge when authorized by local rule - must issue a scheduling order:

(A) after receiving the parties' report under Rule 26(f); or

(B) after consulting with the parties' attorneys and any unrepresented parties at a scheduling conference or by telephone, mail, or other means.

(2) Time to Issue.

The judge must issue the scheduling order as soon as practicable, but in any event within the earlier of 120 days after any defendant has been served with the complaint or 90 days after any defendant has appeared.

(3) Contents of the Order.

(A) Required Contents. The scheduling order must limit the time to join other parties, amend the pleadings, complete discovery, and file motions.

(B) Permitted Contents. The scheduling order may:

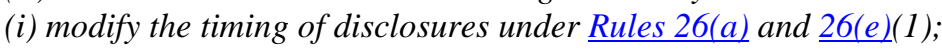

(ii) modify the extent of discovery;

(iii) provide for disclosure or discovery of electronically stored information;

(iv) include any agreements the parties reach for asserting claims of privilege or of protection as trialpreparation material after information is produced;

(v) set dates for pretrial conferences and for trial; and

(vi) include other appropriate matters.

(4) Modifying a Schedule.

A schedule may be modified only for good cause and with the judge's consent. 
apresentação de requerimentos, sendo facultado determinar outras questões relacionadas aos limites objetivos e subjetivos da demanda. O cronograma fixado nesta audiência apenas poderá ser alterado por justa causa e mediante aprovação do juiz.

Esta primeira audiência pode ser seguida de audiências de acompanhamento (statutes conferences), cujo objetivo é acompanhar o desenrolar do procedimento, principalmente durante a fase instrutória (alguns juízes, por exemplo, realizam uma no meio e outra ao final da fase instrutória), e da apresentação de pre-filing motions (em que são debatidos os argumentos e razões que justificam a eventual proposição de uma manifestação ou pedido de reconsideração da parte), tudo isso antes da pretrial conference.

A pretrial conference, diferentemente da audiência preliminar prevista no Código de Processo Civil brasileiro (com a qual muitas vezes é comparada), ocorre depois da fase instrutória e apenas momentos antes do julgamento, tendo por objetivo, de acordo com a regra 16 das Federal Rules of Civil Procedure (FRCP), melhorar a qualidade do julgamento que a sucede através do gerenciamento da demanda, facilitando-se mais uma vez a obtenção de acordo ${ }^{260}$.

$\mathrm{Na}$ pretrial conference, de acordo com a regra 16(c)(2) das FRCP, devem ser consideradas as seguintes questões, visando a economia e efetividade processuais:

(A) formulação e simplificação das questões, com a eliminação das pretensões ou defesas infundadas.

(B) aditamento/emenda dos pedidos, se necessário ou desejável.

(C) obtenção de admissões e estipulações sobre os fatos e os documentos para evitar provas desnecessárias e decidir previamente sobre a admissibilidade de provas.

(D) evitar provas desnecessárias e cumulativas, e limitar o uso de testemunhos sob a regra federal de evidência 702.

(E) determinar a adequação e o prazo para julgamento sumário sob a regra 56.

(F) controlar e agendar a fase de produção de provas, incluindo ordens que afetem o disclosure e as provas produzidas sob as regras 26,29 e 37.

(G) identificar testemunhas e documentos, agendando a propositura e a troca de qualquer documento referente à audiência preliminar, e fixando as datas para outras audiências e para o julgamento.

(H) encaminhamento de questões ao magistrate judge ou ao special master.

(I) resolver o caso por acordo ou usando procedimentos especiais para contribuir à resolução da disputa quando autorizado por lei ou norma local.

\footnotetext{
${ }^{260}$ Em termos mais específicos, seus objetivos são: (1) expediting disposition of the action; (2) establishing early and continuing control so that the case will not be protracted because of lack of management; (3) discouraging wasteful pretrial activities; (4) improving the quality of the trial through more thorough preparation, and; (5) facilitating settlement.
} 
(J) determinar a forma e o conteúdo da decisão que encerra a audiência preliminar (pretrial order).

(K) decisão das questões e pedidos pendentes.

(L) adoção de procedimentos especiais para o gerenciamento de ações potencialmente difíceis ou prolongadas, que podem envolver questões complexas, múltiplas partes, questões legais difíceis ou problemas probatórios incomuns.

(M) determinar julgamento separado, de acordo com a regra 42(b), para um pedido, reconvenção, crossclaim, pedido de terceiro ou questão particular.

(N) determinar a apresentação de provas no início do julgamento sobre questão que poderia, sobre a prova, ser a base para o julgamento como matéria de direito sob a regra 50(a) ou o julgamento sobre achados parciais sob a regra 52(c).

(O) estabelecer um limite razoável de tempo permitido para apresentar provas.

(P) facilitar de outras formas a justa, célere e não custosa disposição da ação. ${ }^{261}$

Assim, uma importante diferença entre a audiência preliminar no Brasil e a pretrial conference é o momento em que ambas ocorrem - uma no início do processo e outra em sua fase final, antes do julgamento - e os reflexos disso em relação às questões probatórias, pois grande parte da pretrial conference é destinada à análise dos meios e matéria de prova. No Brasil, a instrução probatória não está apenas a cargo dos advogados, havendo poderes instrutórios do juiz que não se concentram somente na audiência preliminar, momento que antecede a fase de produção de provas.

A pretrial conference é finalizada com uma decisão judicial - pretrial order, que resume o que foi decidido e também apresenta os próximos passos do procedimento através de um plano de julgamento, normalmente previsto para data não tão distante desta audiência. A pretrial conference é a audiência mais trabalhosa de todas, dado o seu objeto e as atribuições que cabem ao juiz e às partes.

\footnotetext{
${ }^{261}$ Tradução livre. No original: A) formulating and simplifying the issues, and eliminating frivolous claims or defenses; (B) amending the pleadings if necessary or desirable; (C) obtaining admissions and stipulations about facts and documents to avoid unnecessary proof, and ruling in advance on the admissibility of evidence; $(D)$ avoiding unnecessary proof and cumulative evidence, and limiting the use of testimony under Federal Rule of Evidence 702; (E) determining the appropriateness and timing of summary adjudication under Rule 56; $(F)$ controlling and scheduling discovery, including orders affecting disclosures and discovery under Rule 26 and Rules 29 through 37; $(G)$ identifying witnesses and documents, scheduling the filing and exchange of any pretrial briefs, and setting dates for further conferences and for trial; $(H)$ referring matters to a magistrate judge or a master; (I) settling the case and using special procedures to assist in resolving the dispute when authorized by statute or local rule; $(J)$ determining the form and content of the pretrial order; $(K)$ disposing of pending motions; $(L)$ adopting special procedures for managing potentially difficult or protracted actions that may involve complex issues, multiple parties, difficult legal questions, or unusual proof problems; (M) ordering a separate trial under Rule 42(b) of a claim, counterclaim, crossclaim, thirdparty claim, or particular issue; $(N)$ ordering the presentation of evidence early in the trial on a manageable issue that might, on the evidence, be the basis for a judgment as a matter of law under Rule 50(a) or a judgment on partial findings under Rule 52(c); $(O)$ establishing a reasonable limit on the time allowed to present evidence; and $(P)$ facilitating in other ways the just, speedy, and inexpensive disposition of the action.
} 
Sanções podem ser aplicadas aos advogados e partes (quando auto-representadas) que não comparecem à scheduling e à pretrial conferences, que não se preparam para participar delas ou não participam de boa fé, e que não cumprem as ordens judiciais pósconferências ou qualquer outra decisão delas decorrentes, podendo haver o estabelecimento de custas e taxas a serem pagas pela não observância das regras referentes ao gerenciamento, tal como previsto pela regra 16(f) das FRCP.

Normalmente somente os advogados estão presentes nestas audiências, que podem ser realizadas por telefone (como ocorre na District Court de Connecticut), mas é importante que estejam investidos de poderes para tratar sobre possibilidades de acordo. Também é comum que os juízes requeiram a apresentação de memorandum ou relatórios das partes antes de cada audiência, com a fixação dos pontos e argumentos centrais que serão objeto de cada encontro, para fins de otimização do tempo e obtenção de melhores resultados.

Uma das peculiaridades observadas neste sistema é o incentivo à objetividade e ao viés prático das discussões que ocorrem durante as audiências: os advogados são bem diretos no debate da controvérsia e das questões centrais objeto da demanda, chegando a antecipar algumas estratégias, discutir a possibilidade de recursos, havendo também uma flexibilidade do juiz em gerenciar o procedimento e fixar os prazos.

Houve uma nítida redução de julgamentos (trials) após a implementação da pretrial conference, na nova redação do art. 16 das FRCP, que define as linhas mestras sobre o gerenciamento das demandas.

Para Judith Resnik, a realização desta audiência e os acordos obtidos em sua decorrência têm sido alguns dos fatores mais relevantes na mudança de foco da litigância para fora da adjudicação judicial. De acordo com dados da Justiça Federal, em 2000, de 100 casos que começavam menos de 3 findavam em julgamento. Em contraste, em 1938 (ano em que foram promulgadas as Federal Rules of Civil Procedure), de 100 casos propostos, aproximadamente 20 terminavam em julgamento ${ }^{262}$

${ }^{262}$ RESNIK, Mediating preferences cit, p. 156. Sobre os dados estatísticos, vide Administrative Office of the U.S Courts, Annual Report of the Director tbl. C-4 A (U.S. District Courts Civil cases terminated by District 
Importante ainda ressaltar o papel das ferramentas tecnológicas utilizadas em prol do case management nos EUA, que é considerado nas Cortes Federais um internet-based system. O protocolo de petições é feito on line, o pagamento das taxas pode ser feito com o uso de cartão de crédito, e os documentos do processo estão disponíveis apenas em via eletrônica (justiça sem papel - eletronic case files).

Com esse sistema houve importante melhora no acesso aos documentos pelas partes, advogados e juízes - que recebem uma senha de acesso, observadas alguma regras de confidencialidade - além da agilização da notificação das partes via email, com informação em tempo real acerca das decisões judiciais, otimização dos serviços prestados pela Corte, dentre outros benefícios. A alimentação do sistema pode ser feita pelas partes ou pelos funcionários da Corte (o que ocorre neste último caso em relação à petição inicial, antes da distribuição a um dos juízes, e frequentemente quando as partes se autorepresentam), que escaneiam os documentos disponíveis on line em formato PDF portable document format ${ }^{263}$.

Quanto à mediação, que pode ser indicada pelas partes ou pelo juiz em várias fases do procedimento, ela está muito ligada ao gerenciamento do processo, sendo alegada a maior probabilidade de acordo quando a mediação é realizada no inicio do processo, antes do final da fase probatória, uma vez já decididas questões incidentais ${ }^{264}$. Mesmo não havendo acordo entre as partes, a mediação tem-se revelado útil para uma melhor condução das fases do procedimento.

A Juíza Federal Janet Bond Arterton ressalta que a coordenação entre a mediação e o gerenciamento de processos tem sido frequentemente realizada na District Court de Connecticut, principalmente pelos magistrate judges. A mediação tende inclusive a facilitar a produção de provas, que pode se focar em um acordo no início da demanda,

and Action taken during the 12 month period ending Sept. 30, 2000). O relatório ressalta, todavia, que nos $97 \%$ de processos que não foram a julgamento, não necessariamente houve acordo.

${ }^{263}$ Mais informações sobre o case management system na District Court de Connecticut podem ser obtidas no site http://www.ctd.uscourts.gov/cmecf/index.htm. Acesso em 20/12/2010. Treinamentos são frequentemente oferecidos aos advogados pela Corte.

${ }^{264}$ Isso foi bastante mencionado na pesquisa empírica realizada. É o que também destacam McAdoo, Welsh e Wissler: Holding mediation sessions sooner after cases are filed, however, yields several benefits. Cases are more likely to settle, fewer motions are filed and decided, and case disposition time is shorter, even for cases that do not settle in mediation. (...) Thus, program designers should consider scheduling mediation sessions to be held at some reasonable point before discovery is completed but only after dispositive or their critical motions have been decided. Cf. MCADOO et al. Institutionalization cit., p. 9. 
antes que maiores gastos sejam despendidos com a instrução probatória da causa. E mesmo que o acordo não seja obtido, a mediação realizada e o contato das partes em um ambiente de autocomposição pode fazer com que o caso seja resolvido de forma mais rápida ou chegue mais preparado a um julgamento final ${ }^{265}$.

Paulo Eduardo Alves da Silva, ao analisar o case management nos EUA, considera quatro elementos que interagem com ele e são interdependentes: os mecanismos de resolução alternativa de conflitos, a triagem dos casos (screening process), o envolvimento judicial imediato (early judicial involvement) e a organização dos tribunais ${ }^{266}$.

Não obstante os auxiliares do juiz, como os special masters e os magistrate judges, tenham um papel importante no gerenciamento das demandas, para alguns autores o protagonismo é exercido pelos advogados, tanto durante a pretrial conference como durante a fase de produção de provas e de gerenciamento do processo, o que reflete o seu papel protagonista no sistema adversarial vigente nos EUA.

Judith Resnik chega a denominar o case management de lawyer management, focando na atuação dos advogados durante esta fase. Ainda que o gerenciamento do processo durante a fase procedimental anterior ao julgamento (pretrial process) seja na maior parte das vezes denominada de gerenciamento judicial do caso, Resnik acha que a expressão lawyer management melhor captaria os objetivos desta fase, na qual os juízes tem lutado para manter seu papel de direção, instruindo os advogados em como preparar os casos e fiscalizando suas atuações ${ }^{267}$.

Há também certa preocupação sobre o protagonismo que assumiram os advogados em relação aos meios alternativos de solução de conflitos no Judiciário, estando as partes muitas vezes ausentes das sessões de mediação, conduzidas apenas por seus advogados - o que acontece comumente nos casos envolvendo companhias de seguro. Esta e outras questões serão exploradas no item seguinte referente à pesquisa empírica.

\footnotetext{
${ }^{265}$ Cf. ARTERTON, Alternative Dispute Resolution cit., p. 226.

${ }^{266}$ SILVA, Paulo Eduardo Alves da. Gerenciamento de processos judiciais. São Paulo: Saraiva, 2010, p. 40.

267 Judicial management of the pretrial process is sometimes termed case management. I think lawyer management better captures the goals of judicial superintendence, as judges strive both to serve as supersenior partners, instructing lawyers on how to prepare cases, and as super-egos, seeking to curb lawyer misbehavior. Cf. RESNIK, Mediating preferences cit., p. 164.
} 
Sobre o papel dos advogados, o contato cada vez mais rarefeito do mediador com as partes e o ajustamento de acordos em termos meramente monetários, Nancy Welsh considera o risco de a mediation se transformar em litigotiation, uma mistura de litigation com mediation:

\begin{abstract}
Pesquisas recentes sugerem que o processo de solução de disputas cada vez mais parece uma tradicional sessão de negociação bilateral entre os advogados das partes ou uma gloriosa audiência judicial de acordo.

Os advogados dominam as sessões de mediação, enquanto seus clientes possuem um papel muito reduzido. Os mediadores são selecionados de acordo com suas habilidades para avaliar os casos e para estimar os pontos fortes e fracos de cada lado. Os mediadores passam a valorizar menos as sessões conjuntas, indo direto para as sessões individuais com cada parte (caucuses). Ademais, um pequeno percentual de acordos produzidos nestas sessões de mediação são criativos e não baseados em valores monetários.

(...)

Se a mediação é vista simplesmente como uma forma de aumentar o número de acordos que resultam da negociação que ocorre na maioria dos casos cíveis, a evolução deste processo parece representar uma adaptação bem sucedida para a realidade do nosso sistema civil de litigotiation $^{268}$.
\end{abstract}

\title{
d) O papel dos magistrate judges nas Cortes Federais e a burocratização do Judiciário
}

No que se refere ao aparato de juízes e auxiliares que atuam nas Cortes Federais, convém tratar mais detidamente dos magistrate judges, principalmente diante do papel que eles exercem em relação às mediações.

Diferentemente dos juízes federais, que são apontados pelo Presidente dos EUA e aprovados pelo Senado, os magistrate judges são apontados pelos próprios juízes da Corte (District Judges) para exercerem um mandato de oito anos, com dedicação parcial ou total, que pode ser prorrogado ilimitadas vezes ${ }^{269}$.

${ }^{268}$ Tradução livre. No original: Recent research suggests that this dispute resolution procedure increasingly
resembles a traditional bilateral negotiation session between attorneys (albeit with a third party in
attendance) or a "glorified" judicial settlement conference. Attorneys dominate the mediation sessions, while
their clients play no or minimal roles. Mediators are selected for their ability to value cases and to assess
each side's strengths and weaknesses. Mediators also increasingly bypass or marginalize the joint session in
order to move quickly to caucuses. Moreover, a surprisingly small percentage of the settlements produced
by these mediation sessions are creative or even nonmonetary.(...) If mediation is viewed simply as a means
to enhance the deal-making that occurs in the negotiated settlement of most civil cases, the process' evolution
appears to represent a successful adaptation to the realities of our civil system of "litigotiation”. Cf.
WELSH, Making deals in Court-Connected cit,. pp. $788-789$.
${ }^{269}$ Sobre os magistrate judges, vide o Título 28 , Parte III, Capítulo 43 do United States Code. Acerca do seu
salário, esta legislação determina que for full-time United States magistrate judges up to an annual rate equal 
Eles precisam ser advogados, devidamente inscritos na Associação de Advogados há pelo menos cinco anos, não podem ter nenhuma relação por casamento ou parentesco com os juízes federais da Corte para o qual são apontados e precisam passar por uma seleção pública de acordo com os padrões e procedimentos estabelecidos pela Judicial Conference of the United States.

Uma figura semelhante ao magistrate judge é a do juiz leigo previsto na Lei dos Juizados Especiais (Lei n ${ }^{0}$ 9099/95), que determina que os juízes leigos são auxiliares da Justiça, recrutados, preferentemente, entre os advogados com mais de cinco anos de experiência, estando impedidos de exercer a advocacia perante os Juizados Especiais, enquanto no desempenho de suas funções (art. $7^{\circ}$, p. único). Estes juízes, além de realizarem atividades conciliatórias, poderiam dirigir a fase de instrução probatória, proferindo decisão que seria submetida ao Juiz togado para fins de homologação ou substituição (arts. 37 e 40). Percebe-se, entretanto, que os juízes leigos não tiveram muita aceitação na prática dos Juizados ${ }^{270}$, diferentemente do que ocorreu em relação aos conciliadores.

O número de magistrate judges varia em cada District Court, onde cada grupo de juízes tem um magistrate judge designado para trabalhar junto a ele, exercendo variadas atividades jurisdicionais ${ }^{271}$ além de possuir poderes coercitivos (contempt authority) em alguns casos. Os magistrate judges atuam, por exemplo, durante a fase instrutória do procedimento (discovery), nas pequenas causas, em análise de questões criminais e questões relativas à audiência preliminar (pretrial conference), além de proferirem decisões, realizarem mediações e conduzirem o julgamento pelo júri, podendo assumir o processo do início ao fim, desde que haja o consenso das partes. Algumas de suas decisões são encaminhadas aos juízes federais a título de recomendações, e podem ser revistas antes de se tornarem efetivas.

to 92 percent of the salary of a judge of the district court of the United States, as determined pursuant to section 135, and at rates for part-time magistrate judges of not less than an annual salary of \$100, nor more than one-half the maximum salary payable to a full-time magistrate judge.

${ }^{270}$ Com exceção de alguns casos específicos, como se verifica no Estado do Rio Grande do Sul.

${ }^{271}$ Estão fora de sua jurisdição - a motion for injunctive relief, for judgment on the pleadings, for summary judgment, to dismiss or quash an indictment or information made by the defendant, to suppress evidence in a criminal case, to dismiss or to permit maintenance of a class action, to dismiss for failure to state a claim upon which relief can be granted, and to involuntarily dismiss an action. 
O Federal Judicial Center conduz periodicamente programas de treinamento e seminários aos magistrate judges, havendo um programa introdutório que deve ser feito pelos novos magistrados no prazo de até um ano após sua indicação.

Na District Court de Connecticut, tanto os magistrate judges como os special masters atuam como mediadores. Como os special masters são especialistas em determinadas áreas, isso acaba sendo um fator importante para definir quais casos serão encaminhados aos mesmos: para os special masters normalmente vão as demandas mais complexas, em termos de objeto, e para os magistrate judges são encaminhadas as mediações mais demandantes em termos de tempo, pois quando atuam em dedicação integral eles tem mais disponibilidade, além de serem funcionários da Corte, onde normalmente realizam as sessões de mediação.

A Juíza Janet Bond Arterton, da District Court de Connecticut, em entrevista realizada no dia 18.05.2009 em contribuição à pesquisa empírica que compõe esta tese, relatou que envia aos special masters casos relativos a personal injury e que tirem proveito do grau de sua especialização, enquanto aos magistrate judges direciona casos mais gerais relacionados à discriminação de empregados, demandas contra a cidade, demandas de fundo constitucional, dentre outros. Embora não existam estatísticas sobre os casos mediados, a Juíza Arterton acredita que a grande maioria das decisões da Corte dizem respeito a questões de direito que não são objeto de mediação. E haveria em sua opinião mais acordos em mediações realizadas pelos magistrate judges do que pelos special masters, que em Connecticut realizam as mediações como atividade pro-bono.

Como parte observacional da pesquisa empírica, a autora do presente trabalho assistiu a uma série de mediações realizadas pela Magistrate Judge que trabalha junto à Juíza Arterton e a outros dois juízes da District Court de Connecticut. Em conversas com a Magistrate Judge Joan G. Margolis, que está no seu quarto termo como magistrate judge em Connecticut, foi possível constatar que a maior parte de sua atuação está relacionada à fase instrutória do processo (discovery), audiências preliminares (pretrial conferences) e mediações.

Em sede de mediação, a maioria dos casos que conduz está relacionada à discriminação de empregados, embora haja também variados casos sobre matéria 
comercial. Quanto ao case management, a juíza Margolis tenta seguir o cronograma e planejamento fixados no início da demanda. A notificação é normalmente feita por via eletrônica aos advogados, momento em que a juíza especifica se as partes precisam estar presentes na sessão de mediação ou apenas disponíveis via telefone, sendo relevante que os advogados estejam investidos de autoridade para fixar os termos do acordo. A juíza não se reúne com as partes sem a presença dos advogados, mas comentou que às vezes é importante ouvir as partes para que elas sintam que têm voz no processo, principalmente quando questões emocionais estão envolvidas. A juíza sempre faz ressalvas no início das sessões de mediação sobre o seu papel e a confidencialidade das declarações feitas durante a sessão.

A juíza Margolis comentou ainda que os District Judges direcionam os casos para a sua mediação em diferentes momentos. Há juízes que preferem fazê-lo no início da demanda, enquanto outros o fazem mais tardiamente, após o summary judgement, pretrial conference ou mesmo momentos antes do julgamento pelo júri (jury trial). A juíza também afirmou que pode acontecer de ela mesma convidar as partes à mediação em outras fases procedimentais, como durante o discovery. Há inclusive mediações após o julgamento e antes de apelação (post-trial settlement conference).

A juíza Margolis não possuía experiência prévia ou treinamento em mediação, o que foi adquirido apenas indiretamente quando assessorava outro juiz federal na Corte (como law clerk) e durante as atividades exercidas como magistrate judge. Em todas as sessões de mediação observadas, os advogados assumiram protagonismo na definição das questões centrais da demanda, e a juíza Margolis tomou notas da controvérsia do caso e assumiu postura facilitadora do diálogo entre os advogados e as partes, com caucuses (sessões separadas do mediador com cada parte), e algumas vezes postura avaliadora das alternativas de consenso ante os resultados possíveis de se obter junto à Corte, inclusive com recomendação de acordo às partes. Tentou incentivar as partes a pensarem em alternativas não monetárias de resultado, mas muitas vezes os debates se resumiram à discussão de valores.

A duração das sessões de mediação variou bastante, e dois casos mereceram destaque: um sobre matéria comercial (aeroporto em Bridgeport) e outro sobre direito de família (divórcio de Mr. e Mrs. Forbes), cujas sessões duraram mais de cinco horas e 
tiveram interessante condução pela mediadora. Outro caso que chamou atenção foi referente à discriminação de empregado, em que o advogado pediu que a juíza afirmasse diante do seu cliente que recomendaria que ele aceitasse a proposta de acordo da empresa, diante das vantagens observadas, pois essa atitude da juíza surtiria um efeito importante no convencimento da parte. Apesar de o advogado ter tentado usar este argumento de autoridade para convencer seu cliente, não houve acordo nesta sessão.

Enquanto as questões relativas ao discovery são normalmente resolvidas via conferência telefônica, as sessões de mediação são conduzidas presencialmente, muito embora seja comum, quando não há acordo na primeira sessão, entrar em contato por telefone com as partes para saber se as negociações avançaram e se outra sessão de mediação se faz necessária. Muitos feedbacks são obtidos via telefone.

As informações repassadas pela Juíza Margolis para o juiz do caso respeitam as regras de confidencialidade e, ainda que sejam relativas ao progresso e ao resultado da mediação, preservam sob sigilo o teor das discussões e declarações das partes.

Há um debate sobre o risco de os magistrate judges serem considerados uma segunda classe de juízes ${ }^{272}$. Owen Fiss examina este e outros riscos em artigo que trata dos impactos da burocratização do Judiciário, focando na corrosão e difusão da responsabilidade judicial como uma das mais graves consequências desta burocratização, pois atinge a legitimidade da atividade judicial. No momento que entre o juiz e as partes existe uma cadeia burocrática formada por vários indivíduos, e o juiz deixa de dialogar e ouvir as partes e os seus interesses, a sua tarefa de interpretar valores públicos constantes no texto constitucional e em outros textos legislativos restaria comprometida. Nesse cenário, o juiz deixaria de assumir responsabilidade individual pela decisão judicial proferida $^{273}$

Muito embora reconheça que o termo burocracia é usado frequentemente no sentido pejorativo, Fiss busca adotar uma definição de burocracia calcada nas seguintes

\footnotetext{
${ }^{272}$ Algumas vozes deste debate podem ser conferidas em RESNIK, For Owen cit., p. 197.

${ }^{273}$ FISS, Owen M. The Bureaucratization of the Judiciary. The Yale Law Journal, vol. 92, n. 8, jul. 1983, p. 1443. Vide tradução realizada em FISS, Owen. A burocratização do Judiciário. In: SALLES, Carlos Alberto de (Org.). Um novo Processo Civil: estudos norte-americanos sobre jurisdição, constituição e sociedade. Coord. de tradução Carlos Alberto de Salles. São Paulo: Revista dos Tribunais, 2004.
} 
características: i. múltiplos atores; ii. divisão de funções e responsabilidades entre eles; iii. relação hierárquica entre os atores (vertical e não horizontal). Fiss não adota a perspectiva weberiana de burocracia, com ênfase nas regras (rule-governed behavior) e excesso de rigidez regulatória, mas sim a definição de Hannah Arendt, que considera burocracia não a regra pela regra (rule by rule), mas a regra de ninguém (rule by nobody), o que se dá com a fragmentação ou compartimentação da responsabilidade individual do juiz, relembrando o que ocorreu na Alemanha nazista. ${ }^{274}$

Fiss identifica nas Cortes Federais três relações hierárquicas: juiz-juiz (de diferentes instâncias); juiz-funcionários; juiz-subjuiz. Sob esta terceira relação, estão os juízes e certos auxiliares como os magistrate judges, bankruptcy judges e special masters, situados entre os juízes e seus funcionários, mas exercendo poder decisório, embora com algumas restrições em comparação à jurisdição exercida pelo Juiz. Possuem mandatos temporalmente determinados, e muitas vezes suas decisões são sujeitas à supervisão do juiz da causa ${ }^{275}$.

Fiss reconhece o crescimento contínuo dessa burocratização ao notar que o número de magistrate judges, por exemplo, é quase o mesmo de District judges. A seguir seus principais argumentos:

A fragmentação e a compartimentação da tarefa que Arendt descreve na organização nazista está, de fato, presente no Judiciário norte-americano, e pode isolar o juiz das experiências intelectuais críticas que devem informar seu julgamento. Para ilustrar este perigo, considere-se, por exemplo, o uso do sistema de magistrate judges para decisões sobre os pedidos de supressão de confissões, sob a alegação de haverem sido obtidas por meio de coação, que são formuladas pelas partes no curso do processo.

Sob esse sistema, é o magistrate judge quem inicialmente colhe as provas e aplica o direito. O magistrate anuncia a "decisão recomendada", remetendo-a ao juiz, o qual pode determinar uma completa instrução probatória sobre o pedido da parte ou aceitar a decisão do magistrate com base na transcrição impressa.

(...)

O magistrate pode ter ponderado acerca de tal significado, mas esse é apenas um pequeno consolo, uma vez que o juiz perdeu a oportunidade de compreender e crescer - o aprendizado - decorrente da apreciação das provas, da decisão e de sua fundamentação; afinal, é ele e não o magistrate judge quem está investido de poder jurisdicional.

(...)

A utilização do trabalho do magistrate afasta o juiz da exposição dos fatos e do direito no que tange àquela questão particular, de forma a acentuar a falta de completude de sua perspectiva ${ }^{276}$.

${ }^{274}$ Cf. FISS, The Bureaucratization cit., pp. 1450;1452.

${ }^{275}$ Ibidem, pp. 1444;1446.

${ }^{276}$ Ibidem, pp. 1454-1455. 
Assim, a proliferação de subjuízes seria lesiva porque com a delegação de poderes fica enfraquecido o senso de responsabilidade individual dos juízes e insulada a sua experiência no decorrer do procedimento, o que compromete a sua visão geral do caso.

Fiss sugere como alternativas: (i) a criação de mais vagas para juízes federais (District judges), pois diferentemente da proliferação de subjuízes, o aumento no número de juízes não cria uma patologia burocrática ligada à fragmentação e compartimentação de responsabilidade; (ii) a criação pelo Congresso de Cortes Especializadas, como a Corte de Tributos e a Corte Militar de Apelações, substituindo-se uma burocracia maior por duas ou mais burocracias menores. Linhas de revisão teriam de ser criadas para a Suprema Corte, mas em termos de integridade do processo judicial, mais burocracias, porém menores, seriam um ganho. Para Fiss, quanto maior a burocracia, maior é a dispersão da responsabilidade ${ }^{277}$.

\subsection{PESQUISA EMPÍRICA DOS PROGRAMAS DE MEDIAÇÃO}

\section{a) Justificativa para a escolha dos programas de mediação}

Como já ressaltado, foram escolhidos para a pesquisa empírica programas de mediação nos quais se pudesse observar diferentes níveis de institucionalização, modelos e papéis exercidos pelo mediador, juiz, partes e advogados.

Após o estudo das características gerais destes programas disponíveis na internet, exame de textos acadêmicos e conversa com professores e profissionais que atuam na área de meios de solução de conflitos nos EUA, optou-se por pesquisar mais detidamente os Court-connected programs em 4 Estados: Flórida, Ohio, Connecticut e Maine.

${ }^{277}$ Ibidem, pp. 1464-1465. 
A escolha destes programas se justificou pelo fato de estarem em diferentes fases de implementação, e apresentarem volume de casos, níveis de regulação estatal e características diversos.

Em cada Estado e Tribunal há também diferenças entre os programas de mediação, assim como internamente aos programas também pode haver diversidade em relação aos variados tipos de conflitos. É possível que a mediação seja obrigatória em alguns casos e voluntária em outros, e diferentes atores estejam envolvidos no procedimento de mediação. A centralização da administração dos programas, por outro lado, permite identificar as linhas institucionais mestras e uma tendência de harmonização em termos de política judiciária e regulação dessa atividade.

Dentre os Estados pesquisados, Connecticut é o único em que não há um escritório central voltado ao gerenciamento dos programas de mediação. Isso dificulta uma intercomunicação entre os programas do Estado, que funcionam muitas vezes de forma desconectada, assim como a regulação, promoção de treinamentos, uniformização de políticas, incentivos ou mesmo o angariamento de recursos orçamentários estatais destinados aos programas de mediação.

Em todos os demais Estados pesquisados, o questionário da pesquisa empírica foi aplicado junto ao Diretor geral do escritório ou centro estatal de solução de conflitos, sediado na Suprema Corte Estadual. Em Connecticut, por outro lado, escolheu-se um dos programas de mediação (Court-annexed mediation), que funciona junto à Superior Court do Estado, para a análise das características da mediação e aplicação do questionário ${ }^{278}$.

Esta peculiaridade de Connecticut, por outro lado, tornou a sua análise útil em termos comparativos, pois tem se discutido no Estado uma série de medidas para a criação de um Escritório central de solução de conflitos, sendo possível analisar o passo a passo desta institucionalização e quais são os principais atores envolvidos.

\footnotetext{
${ }^{278}$ As respostas obtidas em Connecticut e reproduzidas no quadro comparativo do item seguinte dizem respeito apenas ao Court-annexed mediation voltado às causas cíveis. Há mais 16 programas de mediação em CT ligados ao Judiciário, além de programas voltados a Early Neutral Evaluation, Fact Finding, Arbitration, Summary Jury Trial, Special Master, Pretrial program, Case management conferences, e Juvenile Matters, etc.
} 
Recentemente, formou-se junto à Associação de Advogados deste Estado um Comitê sobre Resolução de Disputas dentro do Judiciário (Standing Committee on Dispute Resolution in the Courts), que reuniu diferentes setores da sociedade com o objetivo de fazer recomendações ao Judiciário, ao Executivo e ao Legislativo sobre os objetivos, políticas e regras referentes aos programas de mediação que funcionam junto às Cortes. Foram formados três grupos de trabalho para tratar dos seguintes temas:

- Programas, Triagem e Mecanismos de encaminhamento dos conflitos à mediação (Programs, screening and referral mechanisms);

- Padrões, Qualificações e Questões éticas (Standards, qualifications and Ethics);

- Fundos (financiamento) e Educação (Funding and education).

Como resultado desse trabalho foi elaborado um relatório bastante interessante em termos de diagnóstico acerca dos programas já existentes, e que também apresenta um guia de princípios, com política regulatória, objetivos e mudanças estruturais a serem implementados no Estado, além de revelar quem está envolvido na articulação estratégica destas recomendações e propostas às três esferas de poder: a) Juízes; b) mediadores e demais interessados nos meios de solução de conflitos (dispute resolution community); c) Associação de advogados (ABA - American Bar Association); d) acadêmicos.

Os pontos considerados como centrais para o sucesso dos programas de mediação foram: (i) forte suporte do Judiciário aos programas de solução de conflitos anexos à Corte; (ii) uma clara definição das formas e opções de solução de conflitos; (iii) um quadro de funcionários da Corte altamente experiente e qualificado para implementar, monitorar e avaliar os programas; (iv) um processo de educação dos advogados e das partes sobre as opções de solução de conflitos, combinado a critérios ou métodos para triagem dos casos que são direcionados aos processos de solução de conflitos; (v) requerimentos aos litigantes para debaterem as escolhas de solução de conflitos e o processo da Corte de triagem e encaminhamento dos casos; (vi) escolha das partes sobre qual processo de solução de conflitos selecionar para cada caso específico; (vii) provedores e servidores, internos e externos ao Judiciário, de qualidade e sistemas de manutenção desta qualidade e 
integridade; (viii) plena integração do programa de solução de disputas com o gerenciamento dos casos e um agendamento realista do julgamento ${ }^{279}$.

No entanto, como as circunstâncias fiscais e orçamentárias não eram favoráveis no momento em que tal relatório e proposta foram apresentados à Presidência do Tribunal em Connecticut, não foram destinados recursos à adoção e concretização destas recomendações pelo Judiciário, tendo havido, por conseguinte, uma suspensão temporária dos trabalhos deste Comitê.

Mesmo sob estas condições adversas, e em face da crise econômica que se alastrou no país em 2008-2009, com reflexos sobre os financiamentos imobiliários e sobre a moradia de milhares de norte-americanos, destacou-se a implantação em Connecticut de um programa de mediação para casos de execução de dívidas com direito real de garantia hipoteca (Foreclosure Mediation Program).

O programa começou por iniciativa de alguns juízes estaduais que abriram a possibilidade de mediação voluntária nestes casos, e após o sucesso obtido durante os dez meses de experimentação, tornou-se um programa de mediação obrigatória. Tendo surgido casuisticamente em face da iniciativa de um pequeno grupo de juízes, hoje o programa serve de modelo a outros Estados. Essa seria uma vantagem da não institucionalização da mediação, pois o seu não engessamento formal permitiria a experimentação de novos projetos, a partir de iniciativas criativas como essa dos juízes de Connecticut.

Na Flórida, por sua vez, encontram-se alguns dos programas de mediação anexos à Corte mais regulados dos EUA, com extensa legislação local a respeito, certificação de mediadores (realizada através do Centro de Solução de Disputas - Dispute Resolution Center) e até mesmo precedentes organizados e comentados em caseloads. Durante a pesquisa foi possível observar reação a esta intensa regulação através da tentativa de

\footnotetext{
${ }^{279}$ Tradução livre. No original: (i) Strong support of court-connected dispute resolution by the judiciary; (ii) A clearly defined set of dispute resolution options; (iii) A highly experienced and qualified court staff to implement monitor and evaluate programs; (iv) A process for educating lawyers and litigants about dispute resolution options combined with criteria or a method for screening cases for dispute resolution processes; (v) Requirements for the litigants to confer concerning dispute resolution choices and a court process for referral; (vi) Party choice about which dispute resolution process to select for a particular dispute; (vii) Qualified providers, both internal and external to the judicial system, and systems for maintaining the quality and integrity of the provider and the process; (viii) Full integration of the dispute resolution program with respect to docket management and realistic scheduling for trial.
} 
transferir poderes às partes e aos advogados, como, por exemplo, durante o procedimento de filtragem dos conflitos, mediante um processo de educação gradual que visa orientá-los a fazer a opção pela técnica compositiva adequada.

O volume de casos nos programas de mediação da Flórida foi o maior observado, em comparação aos outros programas objeto da pesquisa empírica. Nestes programas da Flórida a filtragem dos casos trabalha com a presunção (relativa) de que os conflitos são adequados à mediação (suitability ou eligibility), a menos que os advogados apresentem prova em contrário através de requerimento específico (motion). Há uma ordem administrativa geral do Presidente do Tribunal direcionando os conflitos aos programas de mediação anexos às Cortes (administrative order by the Chief Judge), normalmente após a apresentação de contestação.

Com base no $13^{\text {th }}$ Circuit (um dos circuitos do Tribunal do Estado da Flórida), situado em Tampa, foi montado um fluxo com o passo a passo desde a triagem dos conflitos até a sua solução pela mediação.

\section{ENCAMINHAMENTO DO CASO À MEDIAÇÃO}

(Order or Referral to Mediation)

(É realizado através de ordem administrativa geral do Presidente do Tribunal, requerimento das partes ou encaminhamento feito pelo juiz caso a caso - após a apresentação da contestação)

ACORDO SOBRE A ESCOLHA DO MEDIADOR, DATA E HORÁRIO DA MEDIAÇÃO em dez dias.

(Agreement about the mediator, date and time - 10 days)

(se a seleção e planejamento da data e horário não forem feitos no prazo de 10 dias pelas partes, serão realizados pelo programa e impostos pela Corte)

\section{ADIAMENTO DA MEDIAÇÃO \\ (Deferral of Mediation)}

(qualquer parte pode, dentro de 15 dias a partir do encaminhamento do caso à mediação, apresentar requerimento à Corte para adiar a sessão de mediação e ter uma audiência junto ao Juiz)

\section{SESSÃO DE MEDIAÇÃO}

(Mediation Conference)

(mediação obrigatória, não para que as partes cheguem a um acordo, mas para que se sentem à mesa de negociação)

\section{ACORDO}

(Agreement) 


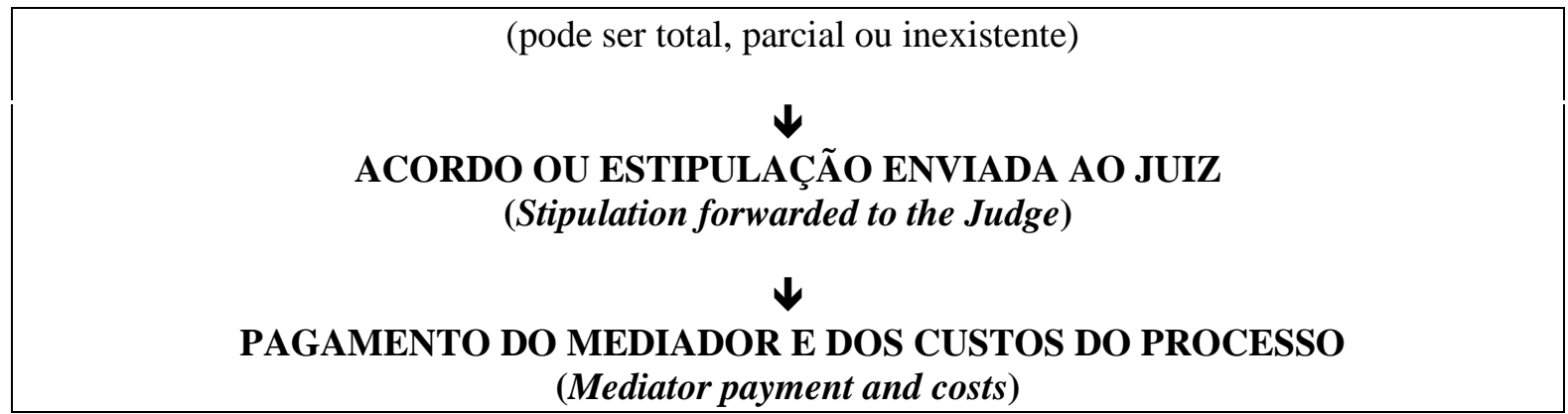

O único requisito para que os casos no 13th Circuit sejam direcionados à mediação é que já tenham sido contestados pelo réu.

Os programas de mediação anexos às Cortes em Ohio, por sua vez, são de porte menor do que na Flórida, mas se destacam pela sua organização, regulação e implementação dirigidas pela Supreme Court Dispute Resolution Section.

Em Maine, por fim, os programas são de médio porte, regulados e coordenados pelo Escritório de Court Alternative Dispute Resolution. Na maior parte dos casos, há a presunção de que os conflitos são passíveis de mediação, salvo prova em contrário (presumptive mediation). Todos os detalhes destes programas estão expostos nos quadros comparativos abaixo. 


\section{b) Quadros comparativos dos programas}

\section{i. Características gerais dos Programas}

\begin{tabular}{|c|c|c|c|c|}
\hline & Ohio & Flórida & Connecticut $^{280}$ & Maine \\
\hline $\begin{array}{c}\text { Ano em que foi } \\
\text { implementada a } \\
\text { mediação / conciliação } \\
\text { no Judiciário }\end{array}$ & 1997 & $\begin{array}{c}\text { 1970's (Citizen Dispute } \\
\text { Settlement Program), } 1978 \\
\text { (programa piloto de mediação) }\end{array}$ & 1996 & $\begin{array}{l}\text { 1970's ( small claims e casos de } \\
\text { divórcio na District Court }{ }^{281} \text { ) }\end{array}$ \\
\hline Tipos de conflitos & $\begin{array}{l}\text { Cíveis, família, trabalhistas, } \\
\text { pequenas causas, etc. } \\
\text { Mediação também em } \\
\text { apelação. }\end{array}$ & $\begin{array}{c}\text { County mediation programs } \\
\text { (causas até } \$ 15.000 \text { ), Small } \\
\text { Claim (até \$5.000), Circuit } \\
\text { Civil Mediation (mais de } \\
\$ 15.000) \text {. Todos os tipos de } \\
\text { conflitos. }\end{array}$ & $\begin{array}{l}\text { Cíveis, família, trabalhistas, } \\
\text { pequenas causas, etc. Há } \\
\text { programas de mediação } \\
\text { específicos para Juvenice e } \\
\text { Mortgage Foreclosure } \\
\text { Cases. }\end{array}$ & $\begin{array}{l}\text { Família (maior volume de } \\
\text { casos), cíveis, comerciais, } \\
\text { ambientais, pequenas causas, } \\
\text { etc. } \\
\text { Não há mediação em causas } \\
\text { trabalhistas e em nível de } \\
\text { apelação. }\end{array}$ \\
\hline $\begin{array}{c}\text { Mediação } \\
\text { (obrigatória }{ }^{282} \text { ou } \\
\text { voluntária) }\end{array}$ & $\begin{array}{l}\text { Na maior parte dos casos, } \\
\text { voluntária. Obrigatória em } \\
\text { uma minoria de casos } \\
\text { (depende do programa de } \\
\text { mediação) }\end{array}$ & $\begin{array}{l}\text { Se o juiz direciona o caso à } \\
\text { mediação, é obrigatória a } \\
\text { presença das partes (sob pena } \\
\text { de sanções). Nas normas há } \\
\text { previsão dos casos que devem } \\
\text { ir para a mediação e das }\end{array}$ & Voluntária & $\begin{array}{l}\text { Obrigatória na maior parte dos } \\
\text { casos, mas admite exceções. Há } \\
\text { a presunção de que os casos são } \\
\text { passíveis de mediação, salvo } \\
\text { prova em contrario } \\
\text { (presumptive mediation) }\end{array}$ \\
\hline
\end{tabular}

${ }^{280}$ Como não há um centro de solução de disputas em nível estadual, analisou-se em Connecticut um dos programas de mediação - Court-annexed mediation, que funciona na Superior Court. As respostas apenas se aplicam a este programa.

${ }^{281}$ Esta District Court é estadual, e não se confunde com a District Court of Maine (Justiça Federal), muito embora haja a semelhança entre os nomes. A District Court estadual (criada em 1961) julga tanto causas cíveis quanto criminais, mas sem Júri. Esta é a diferença em relação à Superior Court, com jurisdição mais ampla e julgamentos por Júri.

${ }^{282}$ Obrigatória é entendida aqui no sentido de a presença ser obrigatória na sessão de mediação (get to the table), e não de necessariamente se fechar um acordo. 


\begin{tabular}{|c|c|c|c|c|}
\hline & & excecões. & & \\
\hline $\begin{array}{l}\text { Regulação } \\
\text { (due process) }\end{array}$ & $\begin{array}{c}\text { Uniform Mediation Act e } \\
\text { regras estaduais e locais (Rule } \\
16 \text { of the Rules of } \\
\text { Superintendence for the } \\
\text { Courts of Ohio) }\end{array}$ & $\begin{array}{l}\text { Programas bastante regulados, } \\
\text { desde } 1987 \text { - Flórida Statutes, } \\
\text { Rules of Civil Procedure, } \\
\text { Florida Rules for Certified and } \\
\text { Court-appointed Mediators, } \\
\text { etc. Há também vários } \\
\text { Comitês que atuam junto à } \\
\text { Supreme Court - ADR Policy } \\
\text { and Rules, Ethics Advisory } \\
\text { Committee, etc. }\end{array}$ & $\begin{array}{l}\text { Regulado por General } \\
\text { Statutes de Connecticut. O } \\
\text { programa não adota o } \\
\text { Uniform Mediation Act. }\end{array}$ & $\begin{array}{c}\text { Regulado por Maine Rules of } \\
\text { Civil Procedure, Statutes, e the } \\
\text { Court Alternative Dispute } \\
\text { Resolution Service (CADRES) } \\
\text { Operational Rules. O programa } \\
\text { não adota o Uniform Mediation } \\
\text { Act. }\end{array}$ \\
\hline $\begin{array}{l}\text { Estrutura do Setor: há } \\
\text { uma administração } \\
\text { central dos } \\
\text { programas? }\end{array}$ & $\begin{array}{l}\text { Sim, a Supreme Court of Ohio } \\
\text { Dispute Resolution Section }\end{array}$ & $\begin{array}{l}\text { Sim, desde } 1986 \text { (Dispute } \\
\text { Resolution Center) }\end{array}$ & Não & $\begin{array}{l}\text { Sim, the Office of Court } \\
\text { Alternative Dispute Resolution } \\
\text { - que faz parte do Maine } \\
\text { Administrative Office of the } \\
\text { Courts e inclui o CADRES. }\end{array}$ \\
\hline Custos para as partes & $\begin{array}{l}\text { Sem custos para as partes, na } \\
\text { maioria dos casos. Alguns } \\
\text { programas cobram taxas ou } \\
\text { subsidiam parcialmente o } \\
\text { pagamento dos custos. }\end{array}$ & $\begin{array}{l}\text { Há custos e taxas. Sem custos } \\
\text { apenas nas pequenas causas } \\
\text { (menos de } \$ 5000 \text { ) e nos casos } \\
\text { de partes que comprovem } \\
\text { impossibilidade de pagamento } \\
\text { (pauperis status). }\end{array}$ & Sem Custos. & $\begin{array}{l}\text { Sim, taxas estabelecidas pelas } \\
\text { Corte e honorários dos } \\
\text { mediadores. Os mediadores } \\
\text { fixam livremente seus } \\
\text { honorários, por hora ou sessão } \\
\text { (na District Court, os } \\
\text { mediadores contratados são } \\
\text { pagos por sessão). }\end{array}$ \\
\hline $\begin{array}{c}\text { Fundos destinados ao } \\
\text { programa }\end{array}$ & $\begin{array}{l}\text { Públicos (Local Court Budget) } \\
\text { - mais de um milhão de } \\
\text { dólares por ano para projetos } \\
\text { pilotos, suplementados por } \\
\text { fundos de taxas judiciárias. } \\
\text { Investimento federal em } \\
\text { alguns programas. }\end{array}$ & $\begin{array}{l}\text { Taxas judiciárias diversas } \\
\text { alimentam um fundo - } \\
\text { Mediation and Arbitration } \\
\text { Trust Fund. }\end{array}$ & $\begin{array}{l}\text { Públicos (Judicial Branch } \\
\text { budget - Superior Court) }\end{array}$ & $\begin{array}{l}\text { Não há fundo público, mas a } \\
\text { utilização das taxas cobradas } \\
\text { das partes para pagamento dos } \\
\text { funcionários e manutenção da } \\
\text { estrutura. }\end{array}$ \\
\hline
\end{tabular}




\begin{tabular}{|c|c|c|c|c|}
\hline $\begin{array}{c}\text { Volume de casos - } \\
\text { dimensão do } \\
\text { programa }\end{array}$ & Médio & Grande ${ }^{284}$ & $\begin{array}{c}\text { Depende do tema - média de } \\
4200 \text { mediações em direito de } \\
\text { família, (grande) } 1000 \text { em } \\
\text { pequenas causas (médio) e 350 } \\
\text { sobre expropriações (pequeno) } \\
\text { por ano na District Court }\end{array}$ \\
\hline $\begin{array}{c}\text { Há outros ADRs } \\
\text { oferecidos pelo } \\
\text { Programa? }\end{array}$ & $\begin{array}{c}\text { Apenas alguns programas } \\
\text { oferecem também arbitragem. } \\
\text { Em direito de família, há além } \\
\text { de mediação o Family group } \\
\text { counseling, teen courts, dentre } \\
\text { outros. }\end{array}$ & $\begin{array}{c}\text { Sim, há arbitragem não } \\
\text { vinculante (non-binding } \\
\text { arbitration program). } \\
\text { mediações ano) }\end{array}$ & $\begin{array}{c}\text { vinculante (non-binding } \\
\text { arbitration program), } \\
\text { avaliação neutra de terceiro, } \\
\text { fact finding, summary jury } \\
\text { Trial. }\end{array}$ & $\begin{array}{c}\text { Sim, na Superior Court há } \\
\text { também arbitragem não } \\
\text { vinculante (non-binding } \\
\text { arbitration program) e } \\
\text { avaliação neutra de terceiro. }\end{array}$ \\
\hline
\end{tabular}

\section{ii. Triagem dos Conflitos (screening process)}

\begin{tabular}{|c|c|c|c|c|}
\hline & Ohio & Flórida & Connecticut & Maine \\
\hline $\begin{array}{l}\text { Como o caso é } \\
\text { direcionado à } \\
\text { mediação? }\end{array}$ & $\begin{array}{l}\text { Juiz (referral), requerimento } \\
\text { das partes caso a caso. Pode } \\
\text { haver um direcionamento geral } \\
\text { em alguns casos (parenting } \\
\text { matter), uma vez apresentada a } \\
\text { contestação. }\end{array}$ & $\begin{array}{l}\text { Juiz (referral), requerimento } \\
\text { das partes caso a caso nos } \\
\text { County Mediation Programs. } \\
\text { Destaque à ordem geral do } \\
\text { Chefe do Judiciário nos } \\
\text { Circuit Mediation Programs }\end{array}$ & $\begin{array}{l}\text { Juiz (referral), } \\
\text { requerimento das partes } \\
\text { caso a caso. É mais comum } \\
\text { a mediação começar com o } \\
\text { requerimento das partes. }\end{array}$ & $\begin{array}{c}\text { Juiz (referral), requerimento } \\
\text { das partes caso a caso. }\end{array}$ \\
\hline
\end{tabular}

${ }^{283} \mathrm{O}$ volume é considerado pequeno quando alcança até 500 sessões de mediação ou conciliação/ano. Entre 500 e 1500 sessões/ano é considerado médio, e acima de 1500 sessões/ano é considerado grande. Estes números foram parâmetros criados para esta pesquisa apenas a título ilustrativo, e se fundam na média de sessões de mediações/conciliações informadas em relação a cada programa.

${ }^{284}$ Dados estatísticos sobre a quantidade de mediações por ano podem ser checadas nos relatórios e dados contidos no site http://www.flcourts.org/gen_public/adr/index.shtml. Acesso em 20/12/2010.

${ }^{285}$ A administradora do escritório estadual de ADR não tem controle do numero de sessões de mediação na Superior Court. 


\begin{tabular}{|c|c|c|c|c|}
\hline & & $\begin{array}{c}\text { (administrative order by the } \\
\left.\text { Chief Judge } e^{286}\right) .\end{array}$ & & \\
\hline $\begin{array}{l}\text { Critérios ou requisitos } \\
\text { para a filtragem dos } \\
\text { conflitos }\end{array}$ & $\begin{array}{l}\text { Não há critérios formalmente } \\
\text { definidos. Cada programa } \\
\text { escolhe e aplica os seus } \\
\text { próprios critérios. O juiz, o } \\
\text { mediador ou funcionário da } \\
\text { Corte (clerk) analisam se o } \\
\text { conflito deve ser objeto de } \\
\text { mediação. }\end{array}$ & $\begin{array}{l}\text { Não há critérios formalmente } \\
\text { definidos. Nos casos } \\
\text { envolvendo violência } \\
\text { (domestic violence cases), por } \\
\text { outro lado, há uma triagem } \\
\text { prévia. }\end{array}$ & $\begin{array}{l}\text { Não há critérios } \\
\text { formalmente definidos. }\end{array}$ & $\begin{array}{l}\text { Não há critérios formalmente } \\
\text { definidos. Nos casos } \\
\text { envolvendo violência (domestic } \\
\text { violence cases), por outro lado, } \\
\text { há uma triagem prévia. }\end{array}$ \\
\hline $\begin{array}{l}\text { Há formulário de } \\
\text { requisição? }\end{array}$ & $\begin{array}{l}\text { Não na maioria dos } \\
\text { programas. }\end{array}$ & $\begin{array}{c}\text { Depende do programa. Não há } \\
\text { esta exigência. }\end{array}$ & $\begin{array}{l}\text { Sim (Court Annexed } \\
\text { Mediation Referral Form), } \\
\text { disponível no website. }\end{array}$ & Não \\
\hline $\begin{array}{l}\text { Quando o caso pode } \\
\text { ser remetido à } \\
\text { mediação? }\end{array}$ & $\begin{array}{c}\text { A qualquer tempo, } \\
\text { preferencialmente no início da } \\
\text { demanda. Mediação pensada } \\
\text { de acordo com o } \\
\text { gerenciamento do caso (case } \\
\text { management) }\end{array}$ & $\begin{array}{l}\text { A qualquer tempo. Nos casos } \\
\text { de ordem geral do Chefe do } \\
\text { Judiciário, após a contestação. }\end{array}$ & $\begin{array}{l}\text { A qualquer tempo,e } \\
\text { normalmente ocorre } \\
\text { momentos antes do } \\
\text { julgamento (trial). }\end{array}$ & $\begin{array}{c}\text { Depende do programa, } \\
\text { normalmente no início do } \\
\text { procedimento. Mediação } \\
\text { pensada de acordo com o } \\
\text { gerenciamento do caso (case } \\
\text { management) }\end{array}$ \\
\hline $\begin{array}{l}\text { Há mediação sem ação } \\
\text { judicial (pre suit } \\
\text { mediation)? }\end{array}$ & $\begin{array}{l}\text { Em alguns programas (4 } \\
\text { deles), sim. }\end{array}$ & $\begin{array}{c}\text { Não. Sem ação judicial, pode } \\
\text { haver, todavia, mediação } \\
\text { comunitária (Citizen Dispute } \\
\text { Settlement Centers) }\end{array}$ & Não & Não \\
\hline $\begin{array}{c}\text { Pode haver o } \\
\text { direcionamento do } \\
\text { conflito para } \\
\text { mediações privadas? }\end{array}$ & Sim & $\begin{array}{c}\text { Não pode haver um } \\
\text { direcionamento direto } \\
\text { (referral), mas sugestões de } \\
\text { mediação fora da Corte são } \\
\text { possíveis. }\end{array}$ & $\begin{array}{l}\text { Sim, mas não é comum que } \\
\text { o juiz o faça. Em casos } \\
\text { mais complexos, as partes } \\
\text { podem requerer a mediação } \\
\text { privada. Nas Cortes há } \\
\text { também listas de } \\
\text { mediadores privados } \\
\text { (private ADR providers). }\end{array}$ & $\begin{array}{l}\text { Sim, pelo juiz ou a } \\
\text { requerimento das partes. }\end{array}$ \\
\hline
\end{tabular}

\footnotetext{
${ }^{286}$ Estas ordem gerais determinam que todos os casos (contestados) sejam remetidos à mediação, a menos que os advogados demonstrem que a mediação não é o processo adequado ao caso em questão (any part may, within 15 days of the Order referring parties to mediation, file a motion with the Court to defer the proceeding).
} 


\section{iii. Características do Procedimento}

\begin{tabular}{|c|c|c|c|c|}
\hline & Ohio & Flórida & Connecticut & Maine \\
\hline $\begin{array}{c}\text { A mediação suspende } \\
\text { a ação judicial em } \\
\text { curso? }\end{array}$ & $\begin{array}{l}\text { Em geral, não. Mas pode haver } \\
\text { prorrogação de prazos em face } \\
\text { da mediação. }\end{array}$ & $\begin{array}{l}\text { Em geral, não. A menos que } \\
\text { estipulado caso a caso pelo } \\
\text { juiz ou requerido pelas partes. }\end{array}$ & $\begin{array}{l}\text { Nos casos cíveis e de } \\
\text { família, a ação pode ser } \\
\text { suspensa pelo período } \\
\text { máximo de } 90 \text { dias. }\end{array}$ & Não \\
\hline $\begin{array}{l}\text { É possível realizar a } \\
\text { mediação por telefone } \\
\text { ou email? }\end{array}$ & $\begin{array}{l}\text { Sim, em nível de apelação, } \\
\text { parte expressiva das } \\
\text { mediações é realizada via } \\
\text { conferência telefônica. }\end{array}$ & $\begin{array}{l}\text { Não. Mas em algumas sessões, } \\
\text { as partes ou advogados podem } \\
\text { estar disponíveis por telefone. }\end{array}$ & $\begin{array}{c}\text { Não. Apenas o } \\
\text { agendamento pode ser feito } \\
\text { por telefone ou email. Mas } \\
\text { alguns juízes mediadores } \\
\text { admitem que as partes } \\
\text { estejam disponíveis por } \\
\text { telefone. } \\
\end{array}$ & $\begin{array}{l}\text { Não. Mas em algumas sessões, } \\
\text { as partes podem estar } \\
\text { disponíveis por telefone } \\
\text { (depende também do consenso } \\
\text { entre as partes e mediador) }\end{array}$ \\
\hline Confidencialidade da & Nesta matéria, os programas & Confidencialidade e exceções & A mediação é confidencial & Há confidencialidade, com \\
\hline
\end{tabular}




\begin{tabular}{|c|c|c|c|c|}
\hline mediação & $\begin{array}{c}\text { seguem o Uniform Mediation } \\
\text { Act. }\end{array}$ & $\begin{array}{c}\text { reguladas pela legislação } \\
\text { estadual - Florida Statutes, } \\
\text { Mediation Confidentiality and } \\
\text { Privilege Act. }\end{array}$ & $\begin{array}{c}\text { - informações não podem } \\
\text { fazer parte dos arquivos do } \\
\text { processo. }\end{array}$ & $\begin{array}{l}\text { exceções previstas em lei. As } \\
\text { declarações na mediação não } \\
\text { podem ser usadas no processo } \\
\text { como elemento de prova } \\
\text { (Maine Rules of Evidence) }\end{array}$ \\
\hline $\begin{array}{c}\text { É possível requerer } \\
\text { aprovação, revisão ou } \\
\text { homologação do } \\
\text { acordo pela Corte? }\end{array}$ & $\begin{array}{l}\text { Em casos envolvendo menores } \\
\text { de idade, a Corte precisa } \\
\text { aprovar o acordo para analisar } \\
\text { se os interesses do menor } \\
\text { foram preservados. Não há } \\
\text { vinculação ao que foi decidido } \\
\text { pelas partes na mediação. }\end{array}$ & $\begin{array}{l}\text { Depende do caso. Em casos } \\
\text { envolvendo direito de família e } \\
\text { interesses de menores é mais } \\
\text { comum haver a revisão } \\
\text { judicial do acordo. Há a } \\
\text { possibilidade de requerimentos } \\
\text { (motions) previstos em lei. E } \\
\text { incidentes referentes ao } \\
\text { cumprimento do acordo } \\
\text { também podem ocorrer. }\end{array}$ & $\begin{array}{l}\text { As partes podem pedir ao } \\
\text { Juiz que homologue o } \\
\text { acordo via decisão judicial, } \\
\text { após análise de seus termos } \\
\text { (judicial order) }\end{array}$ & $\begin{array}{c}\text { Sim, tanto na District Court } \\
\text { como na Superior Court. Na } \\
\text { District Court, o caso pode ser } \\
\text { apresentado ao Juiz ou ao Case } \\
\text { Management Officer para } \\
\text { revisão e elaboração da ordem } \\
\text { judicial. Na Superior Court, as } \\
\text { partes devem apresentar o } \\
\text { acordo em } 10 \text { dias para o juiz } \\
\text { proferir a ordem homologatória. }\end{array}$ \\
\hline $\begin{array}{l}\text { É possível recorrer do } \\
\text { acordo? E submetê-lo } \\
\text { à nova mediação? }\end{array}$ & $\begin{array}{l}\text { É possível recorrer do acordo } \\
\text { apenas em caso de coerção, } \\
\text { fraude e outros vícios de } \\
\text { consentimento. Alguns } \\
\text { acordos determinam nestes } \\
\text { casos que as partes se } \\
\text { direcionem ao mediador antes } \\
\text { de procurar a Corte. }\end{array}$ & $\begin{array}{c}\text { Não há um direito recursal, } \\
\text { mas a possibilidade de } \\
\text { requerer que o acordo seja } \\
\text { afastado (motion to put aside } \\
\text { the agreement) em alguns } \\
\text { casos, como fraude e vícios de } \\
\text { consentimento. As partes } \\
\text { podem se submeter também à } \\
\text { nova mediação. }\end{array}$ & $\begin{array}{l}\text { Não é possível recorrer do } \\
\text { acordo, mas as partes } \\
\text { podem se submeter à nova } \\
\text { mediação. }\end{array}$ & $\begin{array}{l}\text { Não é possível recorrer do } \\
\text { acordo, mas as partes podem se } \\
\text { submeter à nova mediação, } \\
\text { consensualmente ou por } \\
\text { determinação judicial. }\end{array}$ \\
\hline
\end{tabular}




\section{iv. Papel dos Advogados}

\begin{tabular}{|c|c|c|c|c|}
\hline & Ohio & Flórida & Connecticut & Maine \\
\hline $\begin{array}{l}\text { As partes precisam } \\
\text { estar assistidas por } \\
\text { advogado? }\end{array}$ & $\begin{array}{c}\text { Depende do programa. A } \\
\text { presença do advogado é } \\
\text { obrigatória em alguns casos - } \\
\text { envolvendo guarda de } \\
\text { menores, violência doméstica, } \\
\text { etc. }\end{array}$ & $\begin{array}{l}\text { Depende do programa. Nos } \\
\text { casos cíveis, geralmente as } \\
\text { partes estão assistidas por } \\
\text { advogados, que desempenham } \\
\text { um papel protagonista durante } \\
\text { a mediação, enquanto em } \\
\text { casos de direito de família há } \\
\text { mais auto-representação ou } \\
\text { mesmo a assistência de apenas } \\
\text { uma das partes por advogado. }\end{array}$ & $\begin{array}{l}\text { É possível a auto- } \\
\text { representação (self- } \\
\text { representation) em alguns } \\
\text { casos. } \\
\text { Mas o juiz pode não aceitar } \\
\text { a auto-representação, } \\
\text { determinando que ambas as } \\
\text { partes estejam assistidas } \\
\text { por advogados. }\end{array}$ & $\begin{array}{l}\text { Não, é possível auto- } \\
\text { representação (self- } \\
\text { representation) em qualquer } \\
\text { caso. }\end{array}$ \\
\hline $\begin{array}{c}\text { Os advogados } \\
\text { precisam estar } \\
\text { presentes na sessão de } \\
\text { mediação? }\end{array}$ & $\begin{array}{c}\text { Depende do programa. Em } \\
\text { alguns casos, pode o advogado } \\
\text { de apenas uma das partes estar } \\
\text { presente. }\end{array}$ & $\begin{array}{l}\text { Não necessariamente (vide } \\
\text { resposta acima) })^{287} .\end{array}$ & $\begin{array}{l}\text { Normalmente as partes e os } \\
\text { advogados estão presentes, } \\
\text { salvo em casos de auto- } \\
\text { representação ou quando as } \\
\text { partes estão disponíveis por } \\
\text { telefone e os advogados } \\
\text { estão investidos de poderes } \\
\text { para negociar }\end{array}$ & $\begin{array}{c}\text { Não necessariamente (vide } \\
\text { resposta acima). Mas se os } \\
\text { advogados são notificados para } \\
\text { comparecer e não se } \\
\text { apresentam sem justa causa, } \\
\text { pode haver sanções aplicadas } \\
\text { pelo juiz. }\end{array}$ \\
\hline $\begin{array}{l}\text { Os advogados podem } \\
\text { estar presentes na } \\
\text { sessão sem as partes? }\end{array}$ & $\begin{array}{l}\text { Depende do programa e do } \\
\text { consentimento das partes. É } \\
\text { importante que os advogados } \\
\text { estejam investidos de poderes } \\
\text { para fechar acordo, ou } \\
\text { consultem as partes por } \\
\text { telefone a respeito. }\end{array}$ & $\begin{array}{c}\text { Depende do programa. } \\
\text { Acontece comumente em } \\
\text { casos cíveis, e não em direito } \\
\text { de família. }\end{array}$ & $\begin{array}{l}\text { Sim, isso ocorre com } \\
\text { frequência em demandas } \\
\text { cíveis envolvendo } \\
\text { companhias de seguro, } \\
\text { quando o valor da demanda } \\
\text { não excede a cobertura } \\
\text { contratual. Os advogados }\end{array}$ & $\begin{array}{l}\text { Sim, isso ocorre com frequência } \\
\text { em demandas cíveis } \\
\text { envolvendo companhias de } \\
\text { seguro. Os advogados devem } \\
\text { estar investidos de poderes para } \\
\text { negociar. }\end{array}$ \\
\hline
\end{tabular}

\footnotetext{
${ }^{287}$ No 13th Judicial Circuit (Hillsborough County), por exemplo, em casos de direito de família em que não está presente o advogado de uma das partes, o acordo objeto da mediação é remetido posteriormente ao advogado ausente, que tem 15 dias para se manifestar.
} 


\begin{tabular}{|l|l|l|l|}
\hline & & & $\begin{array}{c}\text { devem estar investidos de } \\
\text { poderes para negociar. }\end{array}$ \\
\hline
\end{tabular}

\section{v. Papel das Partes}

\begin{tabular}{|c|c|c|c|c|}
\hline & Ohio & Flórida & Connecticut & Maine \\
\hline $\begin{array}{l}\text { As partes precisam } \\
\text { estar presentes na } \\
\text { sessão de mediação? }\end{array}$ & $\begin{array}{c}\text { As partes podem estar } \\
\text { disponíveis por telefone, e não } \\
\text { presencialmente. Pode também } \\
\text { ser requerido ao juiz uma } \\
\text { ordem para trazer as pessoas } \\
\text { com autoridade para fechar } \\
\text { acordo para a mesa de } \\
\text { mediação. }\end{array}$ & $\begin{array}{l}\text { Depende do programa. As } \\
\text { partes podem estar disponíveis } \\
\text { por telefone em alguns } \\
\text { programas. Havendo recusa de } \\
\text { uma das partes a comparecer, } \\
\text { o mediador pode também } \\
\text { apresentar esta questão ao juiz. }\end{array}$ & $\begin{array}{l}\text { Depende do caso e do juiz. } \\
\text { As partes podem estar } \\
\text { disponíveis por telefone e } \\
\text { não presentes na sessão }{ }^{288} \text {. } \\
\text { Havendo recusa de uma das } \\
\text { partes ou dos advogados a } \\
\text { comparecer, o Juiz pode } \\
\text { impor sanções, dependendo } \\
\text { do caso. }\end{array}$ & $\begin{array}{l}\text { Depende do caso. As partes } \\
\text { podem estar disponíveis por } \\
\text { telefone, e não presencialmente. } \\
\text { Podem também as partes } \\
\text { requererem ao juiz uma ordem } \\
\text { para trazer as pessoas com } \\
\text { autoridade para fechar acordo } \\
\text { para a mesa de mediação. }\end{array}$ \\
\hline $\begin{array}{c}\text { Podem as partes } \\
\text { trazer à mediação } \\
\text { outras pessoas para } \\
\text { suporte emocional? }\end{array}$ & $\begin{array}{l}\text { Sim (amigos, familiares). O } \\
\text { Uniform Mediation Act prevê } \\
\text { esta possibilidade. Ocorre com } \\
\text { mais frequência em casos } \\
\text { envolvendo direito de família. }\end{array}$ & $\begin{array}{l}\text { Não há regulamentação a } \\
\text { respeito. Tudo depende do } \\
\text { livre consentimento das partes. }\end{array}$ & $\begin{array}{l}\text { Depende do estabelecido } \\
\text { por cada juiz. }\end{array}$ & $\operatorname{Sim}^{289}$ \\
\hline $\begin{array}{l}\text { O programa coleta } \\
\text { informações se é a } 1^{\mathrm{a}} \\
\text { vez que as partes se }\end{array}$ & Não & $\begin{array}{l}\text { Depende do programa. Não é } \\
\text { comum. O } 13^{\circ} \text { Judicial Circuit } \\
\text { (Hillsborough County), em }\end{array}$ & Não & Não \\
\hline
\end{tabular}

${ }^{288}$ Um dos Juízes da Superior Court de Connecticut, Judge Silbert, elaborou um memorandum no qual esclarece que admite a presença física ou por telefone das partes: "being in attendance can mean physically present or available by phone within no more than ten minutes of any request by the court that the party be contacted to consider and respond to an offer or demand"

${ }^{289}$ Em sessão de mediação sobre guarda de menor que esta autora assistiu em Maine, Portland, a mãe trouxe seu novo marido e o pai foi acompanhado de sua mãe (avó do menor), mas a mediação foi conduzida separadamente com as partes (em caucus). 


\begin{tabular}{|c|c|c|c|c|}
\hline $\begin{array}{l}\text { submetem à } \\
\text { mediação? }\end{array}$ & & Tampa, coleta. & & \\
\hline $\begin{array}{l}\text { São comuns nos } \\
\text { programas disputas } \\
\text { com múltiplas partes? } \\
\text { E ações coletivas? }\end{array}$ & $\begin{array}{c}\text { Depende do programa. O } \\
\text { entrevistado apenas ouviu falar } \\
\text { de uma única demanda } \\
\text { coletiva que fora objeto de } \\
\text { mediação. }\end{array}$ & $\begin{array}{l}\text { Depende do programa e do } \\
\text { tipo de conflito. Não é comum } \\
\text { mediação em ação coletiva. }\end{array}$ & $\begin{array}{l}\text { Casos mais complexos } \\
\text { comumente envolvem } \\
\text { várias partes, ou mesmo } \\
\text { envolvem demandas } \\
\text { coletivas. }\end{array}$ & $\begin{array}{l}\text { Disputas com múltiplas partes } \\
\text { são comuns, mas ações } \\
\text { coletivas não, embora em tese } \\
\text { possam ocorrer na Superior } \\
\text { Court. }\end{array}$ \\
\hline $\begin{array}{l}\text { O programa oferece } \\
\text { algum tratamento } \\
\text { diferenciado quando } \\
\text { há desníveis de poder } \\
\text { entre as partes? }\end{array}$ & $\begin{array}{l}\text { Há treinamentos obrigatórios } \\
\text { que os mediadores que lidam } \\
\text { com casos de violência } \\
\text { doméstica e guarda de } \\
\text { menores precisam fazer, para } \\
\text { evitar riscos às partes mais } \\
\text { vulneráveis. }\end{array}$ & $\begin{array}{l}\text { Isso é tarefa do mediador, que } \\
\text { precisa estar preparado para } \\
\text { lidar com situações de desnível } \\
\text { de poder - não há uma política } \\
\text { geral do programa. Cuidados } \\
\text { maiores devem existir no caso } \\
\text { de auto-representação das } \\
\text { partes, ou quando apenas uma } \\
\text { delas está com advogado. }\end{array}$ & $\begin{array}{l}\text { Os juízes são responsáveis } \\
\text { por estas precauções }\end{array}$ & $\begin{array}{l}\text { Isso é papel do mediador, que } \\
\text { precisa estar preparado para } \\
\text { lidar com situações de desnível } \\
\text { de poder (casos envolvendo } \\
\text { violência, intimidação, abuso, } \\
\text { auto-representação, etc) }\end{array}$ \\
\hline
\end{tabular}

\section{vi. Papel do Juiz}

\begin{tabular}{|c|c|c|c|c|}
\hline & Ohio & Flórida & Connecticut & Maine \\
\hline $\begin{array}{c}\text { Pode o juiz direcionar } \\
\text { o caso à mediação? }\end{array}$ & Sim & Sim & Sim & Sim \\
\hline $\begin{array}{c}\text { Como é o } \\
\text { envolvimento do juiz } \\
\text { durante a mediação? }\end{array}$ & $\begin{array}{c}\text { O juiz tem acesso a um } \\
\text { relatório (status report) que } \\
\text { indica apenas se houve ou não } \\
\text { acordo, e aspectos formais da } \\
\text { mediação (data da mediação, } \\
\text { comparecimento das partes). }\end{array}$ & $\begin{array}{c}\text { O juiz não se envolve durante } \\
\text { a mediação. }\end{array}$ & $\begin{array}{c}\text { O juiz é o mediador. Mas } \\
\text { não é o mesmo juiz que } \\
\text { decide o caso (juiz do trial). } \\
\text { Há júri para causas cíveis. }\end{array}$ & $\begin{array}{c}\text { O juiz não se envolve durante a } \\
\text { mediação. }\end{array}$ \\
\hline
\end{tabular}




\section{vii. Papel do Mediador}

\begin{tabular}{|c|c|c|c|c|}
\hline & Ohio & Flórida & Connecticut & Maine \\
\hline $\begin{array}{l}\text { Precisa ser formado } \\
\text { em direito? Qual é a } \\
\text { formação dos } \\
\text { mediadores? }\end{array}$ & $\begin{array}{l}\text { Não precisa ser formado em } \\
\text { direito. Os mediadores podem } \\
\text { ser advogados, assistentes } \\
\text { sociais, especialistas no objeto } \\
\text { da mediação, etc. A formação } \\
\text { requerida depende do interesse } \\
\text { das partes e características do } \\
\text { caso. }\end{array}$ & $\begin{array}{l}\text { Não precisa ser formado em } \\
\text { direito. Os juízes aposentados } \\
\text { podem ser também } \\
\text { mediadores. }\end{array}$ & $\begin{array}{l}\text { Apenas os juízes podem ser } \\
\text { mediadores no programa } \\
\text { analisado. Em outros } \\
\text { programas (Family Services } \\
\text { mediations, por exemplo), } \\
\text { há mediadores que não são } \\
\text { juízes e nem advogados. }\end{array}$ & $\begin{array}{l}\text { Não precisa ser formado em } \\
\text { direito. Há dois juízes } \\
\text { aposentados que atuam como } \\
\text { mediadores em Maine. }\end{array}$ \\
\hline $\begin{array}{l}\text { São funcionários ou } \\
\text { contratados pela } \\
\text { Corte? }\end{array}$ & $\begin{array}{l}\text { Aproximadamente } 70 \% \text { dos } \\
\text { mediadores são funcionários } \\
\text { das Cortes (Court staff). }\end{array}$ & $\begin{array}{l}\text { Depende do programa e da } \\
\text { mediação. Os mediadores } \\
\text { podem ser: i. funcionários das } \\
\text { cortes (tempo parcial ou } \\
\text { integral); ii. contratados } \\
\text { apenas para uma determinada } \\
\text { mediação (pagos pela Corte); } \\
\text { iii. mediadores privados; iv. } \\
\text { Mediadores voluntários. } \\
\end{array}$ & $\begin{array}{l}\text { Sim, são juízes - judges } \\
\text { trial referees ou sênior } \\
\text { judges. }\end{array}$ & $\begin{array}{l}\text { Os mediadores podem ser: } \mathrm{i} . \\
\text { contratados pela Corte por } \\
\text { tempo parcial (District Court); } \\
\text { ii. Mediadores privados que } \\
\text { fazem parte de uma lista } \\
\text { oferecida pela Corte - list of } \\
\text { rosters (Superior Court). O } \\
\text { mesmo mediador pode trabalhar } \\
\text { na District e Superior Court. }\end{array}$ \\
\hline $\begin{array}{l}\text { Qual é o gênero e a } \\
\text { idade média dos } \\
\text { mediadores? }\end{array}$ & $\begin{array}{c}\text { Não há estatísticas oficiais a } \\
\text { respeito. Mas se pode dizer } \\
\text { que em casos de família a } \\
\text { maioria dos mediadores é } \\
\text { mulher (aprox. 85\%) e em } \\
\text { casos cíveis, homem (aprox. } \\
70 \% \text { ) }\end{array}$ & $\begin{array}{l}\text { Há um controle estatístico do } \\
\text { gênero, língua, etnia e } \\
\text { ocupação dos mediadores dos } \\
\text { programas de mediação } \\
\text { disponível no site do } \\
\text { programa } \\
\text { par. }\end{array}$ & $\begin{array}{l}\text { O grupo é variado. Mas os } \\
\text { entrevistados informaram } \\
\text { que as partes escolhem } \\
\text { mais frequentemente } 3 \text { ou } 4 \\
\text { juízes da lista, com } \\
\text { experiência em mediação. }\end{array}$ & $\begin{array}{l}\text { O grupo é variado, mas há mais } \\
\text { homens mediadores na Superior } \\
\text { Court e mulheres mediadoras } \\
\text { em casos de família. A média } \\
\text { de idade é } 45 \text { anos. }\end{array}$ \\
\hline $\begin{array}{l}\text { Há algum treinamento } \\
\text { ou capacitação }\end{array}$ & $\begin{array}{c}\text { Sim. A Corte oferece } \\
\text { treinamentos regulares, sem }\end{array}$ & Sim, via certificação. & $\begin{array}{l}\text { Os juízes receberam } \\
\text { treinamento em mediação }\end{array}$ & $\begin{array}{l}\text { Sim, e há diferentes requisitos } \\
\text { exigidos para integrar a lista de }\end{array}$ \\
\hline
\end{tabular}

${ }^{290}$ http://199.242.69.70/pls/drc/drc multi_demo. Acesso em 20/12/2010. 


\begin{tabular}{|c|c|c|c|c|}
\hline necessária? & $\begin{array}{l}\text { custo aos mediadores. Há } \\
\text { treinamentos obrigatórios para } \\
\text { mediação em direito de família } \\
\text { (rule 16) }\end{array}$ & & $\begin{array}{c}\text { no início da implementação } \\
\text { do programa, em 1995, e } \\
\text { outro em } 1998 .\end{array}$ & $\begin{array}{l}\text { mediadores (mínimo de horas } \\
\text { de mediação e experiência } \\
\text { prévia). O treinamento pode ser } \\
\text { privado. }\end{array}$ \\
\hline $\begin{array}{l}\text { Há certificação de } \\
\text { mediadores? }\end{array}$ & Não & $\begin{array}{l}\text { Sim. A certificação é regulada } \\
\text { e oferecida pela Suprema } \\
\text { Corte da Flórida, através do } \\
\text { Dispute Resolution Center. Há } \\
\text { renovação da certificação a } \\
\text { cada } 2 \text { anos. } 5605 \text { mediadores } \\
\text { foram certificados (até 2009), } \\
\text { mas nem todos } \\
\text { necessariamente trabalham } \\
\text { junto ao Judiciário. }\end{array}$ & Não & Não \\
\hline $\begin{array}{l}\text { Como se dá a escolha } \\
\text { dos mediadores? Há } \\
\text { alguma lista nas } \\
\text { Cortes? }\end{array}$ & $\begin{array}{l}\text { Escolha consensual das partes. } \\
\text { Há programas que apenas tem } \\
\text { um mediador contratado pela } \\
\text { Corte. Há também lista de } \\
\text { mediadores privados mantida } \\
\text { pelas Cortes. }\end{array}$ & $\begin{array}{l}\text { As partes têm } 10 \text { dias, após o } \\
\text { direcionamento do caso à } \\
\text { mediação, para escolher o } \\
\text { mediador. Não havendo } \\
\text { consenso, a Corte aponta o } \\
\text { mediador }{ }^{291} \text {. }\end{array}$ & $\begin{array}{c}\text { A escolha é feita pelas } \\
\text { partes, que indicam um } \\
\text { mediador dentre os juízes } \\
\text { da Corte. Alguns juízes } \\
\text { veem a mediação como } \\
\text { uma atividade secundária - } \\
\text { a prioridade é o julgamento } \\
\text { (Trial). }\end{array}$ & $\begin{array}{l}\text { Depende. Na Superior Court, } \\
\text { há uma lista de mediadores que } \\
\text { fica com o clerk e também está } \\
\text { disponível on line. As partes } \\
\text { podem escolher mediadores de } \\
\text { fora da lista, mas se não houver } \\
\text { consenso o juiz designará um } \\
\text { mediador desta lista. Nas } \\
\text { pequenas causas, por outro } \\
\text { lado, é o administrador do } \\
\text { programa que aponta o } \\
\text { mediador para o caso e não as } \\
\text { partes. }\end{array}$ \\
\hline $\begin{array}{l}\text { É possível mudar o } \\
\text { mediador no curso do } \\
\text { procedimento? }\end{array}$ & Sim, de forma justificada. & Sim, de forma justificada. & Sim, de forma justificada. & Sim, de forma justificada. \\
\hline
\end{tabular}

${ }^{291}$ Esta alteração nas regras processuais ocorreu em 1990 e permitiu um maior envolvimento das partes no processo de mediação. Estatísticas revelam que em $90 \%$ dos casos há consenso das partes na escolha do mediador. 


\begin{tabular}{|c|c|c|c|c|}
\hline $\begin{array}{l}\text { Mediador pode mudar } \\
\text { de papel, no curso da } \\
\text { mediação, e assumir o } \\
\text { papel de árbitro para } \\
\text { decidir o caso, com o } \\
\text { consentimento das } \\
\text { partes? }\end{array}$ & $\begin{array}{c}\text { Em tese sim, desde que as } \\
\text { partes estejam cientes das } \\
\text { mudanças decorrentes e riscos } \\
\text { (conhecimento de informações } \\
\text { confidenciais). Não se tem, } \\
\text { contudo, conhecimento desta } \\
\text { prática nos programas em } \\
\text { Ohio. }\end{array}$ & $\begin{array}{l}\text { Em tese sim, desde que as } \\
\text { partes estejam cientes dos } \\
\text { impactos desta mudança na } \\
\text { confidencialidade das } \\
\text { informações e imparcialidade } \\
\text { do árbitro, observadas as } \\
\text { regras éticas a respeito. }\end{array}$ & $\begin{array}{l}\text { Não. Há um programa } \\
\text { independente de arbitragem } \\
\text { anexo à corte e não } \\
\text { vinculante. }\end{array}$ & $\begin{array}{c}\text { Sim, na Superior Court ou } \\
\text { junto à mediadores privados. } \\
\text { Não há programa de arbitragem } \\
\text { na District Court. }\end{array}$ \\
\hline $\begin{array}{c}\text { Mediador possui } \\
\text { poderes } \\
\text { discricionários } \\
\text { (contempt of power)? }\end{array}$ & Não & Não & Sim & Não \\
\hline $\begin{array}{l}\text { Mediador pode relatar } \\
\text { ao Juiz algo sobre a } \\
\text { mediação? }\end{array}$ & $\begin{array}{l}\text { Não. Apenas relata se as partes } \\
\text { chegaram a acordo, se estavam } \\
\text { presentes e outras questões } \\
\text { formais. Segue-se o UMA. }\end{array}$ & $\begin{array}{c}\text { Não. Apenas relata se as partes } \\
\text { chegaram a acordo ou não. } \\
\text { Regra } 1730 \text { - Florida Rules of } \\
\text { Civil procedure. }\end{array}$ & $\begin{array}{c}\text { Não. Apenas a } \\
\text { formalização de acordo } \\
\text { entra nos autos do processo. }\end{array}$ & $\begin{array}{l}\text { Não. Apenas relata se as partes } \\
\text { chegaram a acordo, e outras } \\
\text { questões formais (há um } \\
\text { formulário utilizado). }\end{array}$ \\
\hline $\begin{array}{l}\text { O programa segue } \\
\text { regras sobre ética e } \\
\text { responsabilidade dos } \\
\text { mediadores? }\end{array}$ & $\begin{array}{c}\text { Sim, Apêndice F da Regra } 16 \\
\text { da Superintendence for the } \\
\text { Courts of Ohio. }\end{array}$ & $\begin{array}{l}\text { Sim. Regras disponíveis em } \\
\text { Florida Rules for Certified and } \\
\text { Court-appointed mediators. } \\
\text { Há também um Comitê } \\
\text { consultivo sobre o tema - } \\
\text { Mediator Ethics Advisory } \\
\text { Committee. }\end{array}$ & $\begin{array}{l}\text { Não há regras formalmente } \\
\text { estabelecidas a respeito. }\end{array}$ & $\begin{array}{l}\text { Sim, o programa possui seu } \\
\text { próprio Código de Conduta. E } \\
\text { um comitê junto ao CADRES } \\
\text { também atua nesta seara. }\end{array}$ \\
\hline
\end{tabular}

viii. Papel do diretor/administrador dos Programa

\begin{tabular}{|c|c|c|c|c|}
\hline $\begin{array}{c}\text { O escritório central } \\
\text { tem um }\end{array}$ & Ohio & Flórida & Connecticut & Maine \\
\hline
\end{tabular}




\begin{tabular}{|c|c|c|c|c|}
\hline \multicolumn{5}{|l|}{ administrador? } \\
\hline $\begin{array}{l}\text { Cada programa de } \\
\text { mediação tem um } \\
\text { administrador? }\end{array}$ & $\begin{array}{c}\text { Aproximadamente } 80 \% \text { dos } \\
\text { programas têm um } \\
\text { administrador (manager). Os } \\
20 \% \text { que não tem um } \\
\text { administrador que atua em } \\
\text { tempo integral são } \\
\text { administrados pelos } \\
\text { funcionários da Corte que } \\
\text { cumulam esta com outras } \\
\text { funções. }\end{array}$ & $\begin{array}{l}\text { Quase todos os Circuits (que } \\
\text { incluem um ou mais } \\
\text { municípios) tem um } \\
\text { administrador / diretor. }\end{array}$ & $\begin{array}{l}\text { Depende do programa. } \mathrm{O} \\
\text { programa analisado nesta } \\
\text { pesquisa (Court-annexed } \\
\text { mediation) tem um } \\
\text { administrador. }\end{array}$ & $\begin{array}{l}\text { Não. Há apenas um manager } \\
\text { contratado pela Corte e que fica } \\
\text { no escritório central. }\end{array}$ \\
\hline $\begin{array}{c}\text { Quais são as } \\
\text { principais atividades } \\
\text { do administrador? }\end{array}$ & $\begin{array}{l}\text { Gerenciar / monitorar os } \\
\text { programas e os mediadores, } \\
\text { participar de treinamentos, } \\
\text { difundir processos e regras } \\
\text { sobre mediação, trabalhar } \\
\text { junto aos juízes, comunidade, } \\
\text { e demais partes interessadas, } \\
\text { tirar dúvidas sobre o } \\
\text { procedimento, etc. }\end{array}$ & $\begin{array}{c}\text { Gerenciar / monitorar os } \\
\text { programas e os mediadores. } \\
\text { Supervisionar os funcionários } \\
\text { da Corte, fazer o agendamento } \\
\text { e dar suporte administrativo à } \\
\text { mediação, etc. }\end{array}$ & $\begin{array}{l}\text { Gerenciar / monitorar os } \\
\text { programas, tirar duvidas, } \\
\text { trabalhar junto aos juízes e } \\
\text { partes interessadas, etc. }\end{array}$ & $\begin{array}{c}\text { Gerenciar / monitorar os } \\
\text { programas e os mediadores. } \\
\text { Selecionar novos mediadores } \\
\text { para inclusão em lista } \\
\text { disponível na Corte (list of } \\
\text { rosters), oferecer treinamentos, } \\
\text { etc. }\end{array}$ \\
\hline $\begin{array}{l}\text { Qual é a formação do } \\
\text { administrador? }\end{array}$ & $\begin{array}{l}\text { Varia em cada programa. Não } \\
\text { precisa ser advogado, mas é } \\
\text { aconselhável que tenha } \\
\text { experiência em trabalhos junto } \\
\text { à Corte e mediadores. }\end{array}$ & $\begin{array}{l}\text { Não precisa ser advogado, mas } \\
\text { deve ter alguma experiência } \\
\text { prática em mediação. }\end{array}$ & $\begin{array}{c}\text { A administradora } \\
\text { entrevistada é advogada } \\
\text { sem prática em mediação. } \\
\text { Foram entrevistadas mais } \\
\text { duas funcionárias do } \\
\text { programa com larga prática } \\
\text { em mediação. }\end{array}$ & $\begin{array}{l}\text { A administradora entrevistada é } \\
\text { advogada, com experiência } \\
\text { prática em mediação, e } \\
\text { professora de ADR na } \\
\text { Universidade de Maine. }\end{array}$ \\
\hline
\end{tabular}




\section{ix. Outras questões e peculiaridades sobre os programas de mediação}

\begin{tabular}{|c|c|c|c|c|}
\hline & Ohio & Flórida & Connecticut & Maine \\
\hline Peculiaridades & $\begin{array}{l}\text { Nas pequenas causas, as partes } \\
\text { podem realizar a mediação no } \\
\text { mesmo dia em que são } \\
\text { encaminhadas a este } \\
\text { procedimento }\end{array}$ & $\begin{array}{l}\text { Programa demasiadamente } \\
\text { regulado. Quanto à relação } \\
\text { com a Law School, no início o } \\
\text { Dispute Resolution Center se } \\
\text { localizava fisicamente na } \\
\text { Universidade Estadual da } \\
\text { Flórida (1986), mas depois } \\
\text { esta ligação se desfez e } \\
\text { atualmente é pequeno o } \\
\text { contato com a Universidade. }\end{array}$ & $\begin{array}{l}\text { Os juízes mediadores } \\
\text { podem, através de } \\
\text { memorandum, estabelecer } \\
\text { algumas regras } \\
\text { procedimentais próprias } \\
\text { para a mediação - } \\
\text { apresentação de } \\
\text { documentos, argumentos, } \\
\text { presença das partes, etc. }\end{array}$ & $\begin{array}{c}\text { Nas pequenas causas, as partes } \\
\text { podem realizar a mediação no } \\
\text { mesmo dia em que são } \\
\text { encaminhadas a este } \\
\text { procedimento. Destaque ao } \\
\text { papel importante assumido } \\
\text { pelos Guardian ad litem - } \\
\text { apontados pela Corte para } \\
\text { representar os interesses do } \\
\text { menor de idade em casos de } \\
\text { direito de família. Há crescente } \\
\text { regulação desta função pela } \\
\text { Corte. }\end{array}$ \\
\hline $\begin{array}{l}\text { Há controle sobre } \\
\text { repeat players? }\end{array}$ & Não & $\begin{array}{l}\text { Não há controle, mas se } \\
\text { observa principalmente nos } \\
\text { programas menores que tanto } \\
\text { os advogados quanto os } \\
\text { mediadores são repeat players. }\end{array}$ & Não & $\begin{array}{c}\text { Não. Os mediadores e } \\
\text { advogados são repeat players. } \\
\text { Depois da sessão de mediação, } \\
\text { o mediador não pode mediar } \\
\text { conflito entre as mesmas partes } \\
\text { na esfera privada por } 6 \text { meses, } \\
\text { mas pode trabalhar junto aos } \\
\text { mesmos advogados. }\end{array}$ \\
\hline $\begin{array}{c}\text { Há alguma pesquisa } \\
\text { de opinião após a } \\
\text { mediação sobre a } \\
\text { satisfação das partes } \\
\text { com o procedimento e } \\
\text { resultado? }\end{array}$ & $\begin{array}{l}\text { Sim, as partes respondem a um } \\
\text { questionário após a sessão de } \\
\text { mediação. Utilizado para fins } \\
\text { de melhoramento do programa } \\
\text { e da qualidade dos serviços } \\
\text { prestados. }\end{array}$ & $\begin{array}{l}\text { Depende do programa. O } 13^{\circ} \\
\text { Judicial Circuit, em Tampa, } \\
\text { por exemplo, utiliza } \\
\text { questionários para averiguar a } \\
\text { satisfação das partes. }\end{array}$ & Não & $\begin{array}{l}\text { Sim. Há um questionário, } \\
\text { também disponível on line. } \\
\text { Esse questionário é aplicado } \\
\text { mesmo que as partes não } \\
\text { cheguem a um acordo, para } \\
\text { averiguar se a mediação foi útil } \\
\text { como atuou o mediador, etc. }\end{array}$ \\
\hline
\end{tabular}




\begin{tabular}{|c|c|c|c|c|}
\hline $\begin{array}{c}\text { Características do } \\
\text { local em que são } \\
\text { realizadas as sessões } \\
\text { de mediação }\end{array}$ & $\begin{array}{c}\text { A maioria das mediações } \\
\text { ocorre no Judiciário, mas isso } \\
\text { depende dos recursos }\end{array}$ & $\begin{array}{c}\text { Quando os mediadores são } \\
\text { funcionários ou contratados } \\
\text { pela Corte, é mais provável }\end{array}$ & $\begin{array}{c}\text { As mediações ocorrem no } \\
\text { Judiciário, nas salas dos }\end{array}$ & $\begin{array}{c}\text { Na District Court, as mediações } \\
\text { ocorrem no Judiciário. Na } \\
\text { Superior Court, fora do } \\
\text { Jue mediação ocorra no }\end{array}$ \\
Jisponíveis. & Judiciário. & Judiciário. & \\
\hline
\end{tabular}




\section{MEDIAÇÃO NO JUDICIÁRIO BRASILEIRO}

\subsection{Medidas voltadas à institucionalização da mediação}

No Brasil, a mediação e a conciliação estão na pauta dos três poderes: do Legislativo, através de projeto de lei que visa a regular esta matéria; do Executivo, através de políticas públicas de Justiça voltadas à autocomposição dos conflitos; e do Judiciário, através do gerenciamento de processos e de políticas judiciárias conduzidas em favor da mediação e conciliação.

Ainda que essas iniciativas institucionais não sejam excludentes, nota-se um protagonismo que vem sendo assumido pelo Judiciário. Enquanto na institucionalização dos Juizados Especiais o protagonismo coube ao Executivo, através de política pública voltada à sua criação e implementação ${ }^{292}$, no caso da mediação e conciliação nota-se o predomínio de ações do Judiciário voltadas à autocomposição.

Há uma forte tendência de implantação e funcionamento de setores de conciliação e mediação nos Tribunais brasileiros, quer através de projetos-piloto e programas experimentais, quer através de programas mais institucionalizados e regulados.

Os pactos em favor de um Judiciário mais rápido e republicano, firmados em 2004 e 2009 pelos chefes dos Poderes Executivo, Legislativo e Judiciário, representam este comprometimento interinstitucional e concentração de esforços para o aperfeiçoamento do sistema de justiça.

\footnotetext{
${ }^{292}$ Luciana Gross Cunha ressalta que "os juizados especiais surgiram como uma demanda do Poder Executivo, enquanto política pública, estando o objetivo dos juizados ligado à possibilidade de atender conflitos de baixo valor, que não encontravam resposta no Judiciário. Ao longo do processo de criação e implementação, a possibilidade de este instituto melhorar a imagem do sistema de justiça foi aproveitada pelos integrantes da magistratura. (...) No Ministério da Desburocratização, a ideia sobre a criação dos juizados teve origem na percepção de que o Poder Judiciário, como prestador de serviço, apresentava falhas ao atender ao cidadão comum. Assim, inspirado no modelo de Nova York, o Ministério da Desburocratização elabora a pauta de discussões da comunidade jurídica acadêmica e dá início ao processo de criação dos juizados especiais". CUNHA, Juizado Especial cit., pp. 130/133-134.
} 
Neste capítulo são analisadas as medidas implementadas em favor da mediação em três diferentes esferas: (i) no âmbito da atuação e práticas gerenciais do juiz; (ii) no âmbito normativo, quer através de provimentos do Tribunal, quer através de leis federais e projeto de lei; e (iii) no âmbito de práticas e políticas judiciárias nacionais sobre mediação e conciliação, com especial enfoque à atuação do Conselho Nacional de Justiça. Ao final, são apresentados os dados da pesquisa empírica de seis diferentes programas de mediação e conciliação, organizados em quadro comparativo.

\section{a) Mediação e gerenciamento do processo}

A mediação tem uma forte ligação com o gerenciamento dos processos e com práticas de gestão do Judiciário. Em São Paulo, por exemplo, há projetos-pilotos de gerenciamento prevendo a inclusão da mediação nas práticas gerenciais do processo.

Estes projetos-pilotos de gerenciamento de processo, desenvolvidos junto ao CEBEPEJ (Centro Brasileiro de Estudos e Pesquisas Judiciais) e implementados na $2^{\text {a }}$ Vara da Comarca de Serra Negra e na Vara Única da Comarca de Patrocínio Paulista, basearam-se em duas vertentes: (a) o melhor equacionamento das atividades do magistrado e da unidade judicial; (b) a inserção de técnicas de mediação nos processos em curso ${ }^{293}$.

Em relação a esta segunda vertente, o projeto de gerenciamento dividiu o setor de conciliação/mediação em duas fases distintas: pré-processual e processual. Cada uma das fases foi dotada de dois circuitos de conciliação, o $1^{\circ}$ circuito tratava das questões relativas a direito de família, infância e juventude; e o $2^{\circ}$ circuito, de questões cíveis de caráter disponível em geral.

${ }^{293}$ Cf. GAJARDONI, Fernando da Fonseca; ROMANO, Michel Betenjane e LUCHIARI, Valeria Ferioli Lagrasta. O gerenciamento do processo. In: GRINOVER, Ada Pellegrini; WATANABE, Kazuo; LAGRASTA NETO, Caetano (Org.). Mediação e gerenciamento do processo: revolução na prestação jurisdicional e guia prático para a instalação do setor de conciliação e mediação. São Paulo: Atlas, 2008, pp. 18-34. Seguindo o projeto de gerenciamento de processos apresentado pelo CEBEPEJ ao Tribunal de Justiça do Estado de São Paulo, Juliana Demarchi apresentou em sua tese de doutorado uma proposta de implantação de setores de conciliação e mediação anexos às varas judiciais, abordando a adesão dos operadores do direito, a seleção de mediadores, a capacitação necessária, e a metodologia de trabalho empregada. Vide DEMARCHI, Mediação: proposta de implementação, cit, pp. 211-236. 
$\mathrm{Na}$ fase pré-processual, o projeto previa o engajamento do Promotor de Justiça da Comarca, do Defensor Público e dos servidores do Judiciário que efetuavam atendimento ao público, assim como do assistente social, informando as pessoas, prestando orientação jurídica, triando e encaminhando os casos que atendiam para este Setor de Conciliação/Mediação ${ }^{294}$.

$\mathrm{Na}$ fase processual, por sua vez, caberia ao juiz, a qualquer momento, mas especialmente na análise da petição inicial recém distribuída, percebendo a possibilidade de autocomposição, determinar, por despacho, o encaminhamento dos autos ao Setor de Conciliação/Mediação, que agendaria a reunião no circuito adequado. Assim como no setor pré-processual, também aqui era necessário que a mediação fosse marcada dentro do prazo de $30 \operatorname{dias}^{295}$.

Diante dos bons resultados produzidos com o gerenciamento de demandas e a inserção de técnicas de mediação nos processos em curso, além da criação dos setores experimentais de conciliação, em $1^{\mathrm{a}}$ e $2^{\mathrm{a}}$ instâncias, na Capital e nas Comarcas do Interior, foi dado mais um passo rumo à institucionalização, com o Provimento $n^{0}$ 796/03 e o Provimento $n^{0}$ 843/2004, ambos substituídos pelo vigente Provimento $n^{\circ}$ 953/2005 do Conselho Superior da Magistratura do Estado de São Paulo, que "autoriza e disciplina a criação, instalação e funcionamento do Setor de Conciliação ou de Mediação nas Comarcas e Foros do Estado".

Reconhecendo a relação entre o gerenciamento do processo e os meios alternativos de solução de conflitos, Kazuo Watanabe considera que o case management é uma atividade processual que fortalece o controle judicial sobre: a) identificação das questões relevantes; b) maior utilização pelas partes de meios alternativos de solução de controvérsias; e c) tempo necessário para concluir adequadamente todos os passos processuais. O juiz planeja o processo e disciplina o calendário, ouvindo as partes e promovendo a facilitação para uma solução amigável da controvérsia. Mesmo não havendo acordo, ressalta este autor, o processo é planejado e caminha ao julgamento com mais eficiência e menor custo. No Brasil, esse seria o fundamento principal da audiência preliminar do art. 331 do CPC, que não foi adequadamente compreendido e aplicado pelos operadores do direito ${ }^{296}$.

\footnotetext{
${ }^{294}$ GAJARDONI, ROMANO, LUCHIARI, gerenciamento do processo cit., pp. 24-25.

${ }^{295}$ Ibidem, p. 26.

${ }^{296}$ WATANABE, Cultura da sentença cit., p. 689.
} 
$\mathrm{O}$ art. 331 do CPC passou por duas principais reformas legislativas (Leis $\mathrm{n}^{\mathrm{o}} \mathrm{s}$ 8952/1994 e 10444/2002), a audiência preliminar de compulsória tornou-se facultativa, estando os seus objetivos ligados à tentativa de conciliação, saneamento do feito, regularização das questões processuais pendentes e fixação dos pontos controvertidos que serão objeto de prova. Se o direito em litígio não admitir transação, ou se as circunstâncias da causa evidenciarem ser improvável sua obtenção, o juiz poderá, desde logo, sanear o processo e ordenar a produção da prova, sem agendar esta audiência.

A facultatividade da audiência preliminar foi objeto de críticas, pois se saneando o processo por escrito não se aproveitaria um importante momento processual de diálogo entre o juiz e as partes, com o planejamento e preparação do julgamento final ${ }^{297}$. Em vista disso, o PL n ${ }^{\circ}$ 94/2002, que dispõe sobre a mediação, também traz uma nova redação ao art. 331 do CPC, para que a audiência passe a ser obrigatória e com foco tanto na autocomposição e/ou sugestão pelo juiz de outras formas adequadas de solução de conflitos quanto no saneamento do processo ${ }^{298}$

É importante considerar, contudo, que os efeitos da alteração legislativa e a existência de uma maior racionalidade gerencial do processo dependem de outras variáveis, relacionadas à pauta do juiz, à mudança de mentalidade e à postura dos operadores do direito. Se elas não forem consideradas, esta audiência pode significar apenas uma etapa formal a mais e inclusive aumentar o tempo do processo.

\footnotetext{
${ }^{297}$ Cf. DINAMARCO, Cândido Rangel. A Reforma da reforma. $5^{\text {a }}$ ed. São Paulo: Malheiros, 2003, p. 20.

298 "Art. 331. Se não se verificar qualquer das hipóteses previstas nas seções precedentes, o juiz designará audiência preliminar, a realizar-se no prazo máximo de trinta dias, para qual serão as partes intimadas a comparecer, podendo fazer-se representar por procurador ou preposto, com poderes para transigir.

$\$ 1^{\circ} \mathrm{Na}$ audiência preliminar, o juiz ouvirá as partes sobre os motivos e fundamentos da demanda e tentará a conciliação, mesmo tendo sido realizada a tentativa de mediação prévia ou incidental.

$\$ 2^{\circ}$ A lei local poderá instituir juiz conciliador ou recrutar conciliadores para auxiliarem o juiz da causa na tentativa de solução amigável dos conflitos.

$\$ 3^{\circ}$ Segundo as peculiaridades do caso, outras formas adequadas de solução do conflito poderão ser sugeridas pelo juiz, inclusive a arbitragem, na forma da lei, a mediação e a avaliação neutra de terceiro.

$\$ 4^{\circ}$ A avaliação neutra de terceiro, a ser obtida no prazo a ser fixado pelo juiz, é sigilosa, inclusive para este, e não vinculante para as partes, sendo sua finalidade exclusiva a de orientá-las na tentativa de composição amigável do conflito.

$\$ 5^{\circ}$ Obtido o acordo, será reduzido a termo e homologado pelo juiz.

$\$ 6^{\mathbf{0}} \mathrm{Se}$, por qualquer motivo, a conciliação não produzir resultados e não for adotado outro meio de solução do conflito, o juiz, na mesma audiência, fixará os pontos controvertidos, decidirá as questões processuais pendentes e determinará as provas a serem produzidas, designando audiência de instrução e julgamento, se necessário.

Art. 331-A. Em qualquer tempo e grau de jurisdição, poderá o juiz ou tribunal adotar, no que couber, as providências no artigo anterior".
} 
Conforme ressalta Barbosa Moreira, se a audiência só pode ser marcada para data longínqua, por escassez de dias e horas livres nas pautas, de tal maneira que o procedimento escrito passa à frente em rapidez, cessa boa parte dos motivos que justificariam a preferência pela audiência oral; e se o juiz, mesmo zeloso, não tem possibilidade prática, em razão do acúmulo de serviço, de se preparar conforme o necessário para o ato, então aqueles motivos desaparecem por completo. O método concentrado, para vingar, reclama certa mudança de mentalidade: a falta de atmosfera favorável pode asfixiá-lo, por mais requintada que seja a respectiva disciplina e técnica presente nos textos legais ${ }^{299}$

Paulo Eduardo Alves da Silva entende que a lei processual brasileira já contém os elementos necessários ao gerenciamento de processos judiciais: o saneamento do feito (CPC, art. 325 e ss.), a audiência preliminar (CPC, art. 331) e os poderes de direção do juiz (CPC, art. 125) seriam os principais instrumentos legislativos para esse gerenciamento. Há, contudo, uma outra variável que seria necessária, estando relacionada ao modus operandi do sistema de justiça: trata-se das práticas informais do juízo, diretamente relacionadas ao planejamento e processamento dos litígios, tudo isso dependendo de uma cultura jurídico-processual menos formalista e mais favorável ao gerenciamento ${ }^{300}$.

Este autor define o gerenciamento de processos como o planejamento da condução de demandas judiciais em direção à resolução mais adequada do conflito, com o menor dispêndio de tempo e custos. Isso depende de uma postura ativa do juiz no controle do andamento dos feitos e na organização da unidade judiciária (práticas de gestão dos cartórios judiciais). Seus mecanismos básicos são o envolvimento imediato do juízo com as questões da lide, a abertura para a resolução alternativa do conflito e o planejamento do andamento e dos custos do processo $^{301}$.

Assim, há uma estreita ligação entre a mediação e o gerenciamento dos processos pelo juiz e pelo juízo (cartórios judiciais), e isso refletirá diretamente no processo de triagem dos casos para encaminhamento às formas autocompositivas de solução de conflitos, conforme se verá no capítulo 6.

\footnotetext{
${ }^{299}$ BARBOSA MOREIRA, José Carlos. Saneamento do processo e audiência preliminar. Revista de Processo, n. 40, out./dez. 1985, pp. 124-125, 129.

${ }^{300}$ Cf. SILVA, Gerenciamento de processos cit., pp. 19-20.

${ }^{301}$ Ibidem, p. 35.
} 


\section{b) Regulamentação legislativa e judiciária sobre a Mediação e Conciliação}

A regulamentação da mediação e conciliação é vista aqui sob duas perspectivas: (i) regulação legislativa, considerando o Código de Processo Civil vigente, os projetos de lei que tramitam no Congresso sobre mediação e sobre o novo Código de Processo Civil; e (ii) regulação judiciária, através dos provimentos dos Tribunais sobre mediação e conciliação.

O atual Código de Processo Civil prevê alguns momentos de conciliação no processo judicial, sob o controle do juiz, que tem dentre uma de suas atribuições tentar, a qualquer tempo, conciliar as partes (CPC, art. 125), havendo as possibilidades de conciliação em audiência preliminar, audiência de conciliação e instrução e julgamento, quer no rito sumário quer no ordinário.

Há grande expectativa no Brasil sobre a criação de um marco legal acerca da mediação, assim como existiu em relação à arbitragem com a promulgação da Lei $\mathrm{n}^{0}$ 9.307/96, representando esta lei específica sobre mediação um amparo à sua difusão no país e uma forma de uniformização mínima, regulação e fiscalização de sua prática.

Em 1998 foi apresentado ao Congresso Nacional o Projeto de Lei $\mathrm{n}^{\circ} 4837$, de autoria da deputada Zulaiê Cobra Ribeiro, visando institucionalizar e disciplinar a mediação, como método de prevenção e solução consensual de $\operatorname{conflitos}^{302}$. O projeto era simples e conciso, contendo sete artigos sobre a mediação judicial e extrajudicial. Em outubro de 2002, este projeto foi aprovado pela Comissão de Constituição e Justiça da Câmara dos Deputados e enviado ao Senado Federal para revisão, recebendo o número PL n ${ }^{\circ}$ 94, de 2002, e sendo designado relator o Senador Pedro Simon.

O relator apresentou substitutivo estruturado em seis capítulos: I - modalidades de mediação; II - dos mediadores; III - do registro dos mediadores e da fiscalização e controle da atividade de mediação; IV - da mediação prévia; V - da mediação incidental; e VI disposições finais.

\footnotetext{
${ }^{302}$ Um detalhado histórico do passo a passo deste projeto de lei pode ser encontrado no site do Instituto Brasileiro de Direito Processual (IBDP) - http://www.direitoprocessual.org.br/. Acesso em 20/12/2010.
} 
Após a apreciação da Comissão de Constituição, Justiça e Cidadania (CCJC), o projeto seria apreciado pelo Plenário. Entretanto, em 28.03.2007, o então Presidente da CCJC solicitou a reconstituição de diversos projetos de lei sobre a matéria (PL n ${ }^{\circ} \mathrm{s} 4.345 / 98$, 4.827/98, 2.783/00, 3.884/00, 4593/01, 291/03, 3.670/04, 3.762/04; PDC 497/02, PDC 1.682/02, PLP 64/03 e PRC 82/03), o que foi deferido em 10.04.2007. Atualmente o Senado aguarda resposta da Câmara dos Deputados, e os projetos encontram-se parados.

Tanto a versão do Projeto de Lei apresentada por Pedro Simon quanto a apresentada pelo Governo Federal, com base em substitutivo elaborado pelo Instituto Brasileiro de Direito Processual (IBDP), tratam da institucionalização da mediação paraprocessual voltada ao processo civil e convergem em vários aspectos. Definem mediação como a atividade técnica exercida por terceiro imparcial, escolhido ou aceito pelas partes, com o propósito de permitir a prevenção ou solução de conflitos de modo consensual. Quanto à classificação, consideram que a mediação paraprocessual poderá ser prévia ou incidental, em relação ao processo judicial; e judicial ou extrajudicial, conforme a qualidade dos mediadores.

Os mediadores judiciais seriam os advogados com pelo menos três anos de efetivo exercício de atividades jurídicas, capacitados, selecionados e inscritos no Registro de Mediadores. Os mediadores extrajudiciais, por outro lado, seriam os mediadores independentes, selecionados e inscritos no Registro de Mediadores. A mediação prévia extrajudicial, a critério dos interessados, ficaria a cargo de mediador independente ou de instituição especializada em mediação.

$\mathrm{Na}$ mediação paraprocessual, os mediadores judiciais ou extrajudiciais e os comediadores são considerados auxiliares da justiça, e, quando no exercício de suas funções, e em razão delas, são equiparados aos funcionários públicos para os efeitos da lei penal. Os serviços do mediador devem ser sempre remunerados, nos termos e segundo os critérios fixados pela norma local.

A co-mediação foi incentivada pelos projetos, segundo os quais esta poderia se dar a pedido de qualquer das partes ou a critério do mediador, sendo obrigatória nas controvérsias submetidas à mediação que versem sobre o estado da pessoa, devendo dela necessariamente participar psiquiatra, psicólogo ou assistente social. 
Os projetos de lei também determinam que caberá, em conjunto, à Ordem dos Advogados do Brasil, aos Tribunais de Justiça dos Estados e às pessoas jurídicas especializadas em mediação, a formação e seleção de mediadores, para o que serão implantados cursos apropriados, fixando-se os critérios de aprovação, com a publicação do regulamento respectivo.

Os Tribunais de Justiça dos Estados, nos limites de sua jurisdição, manterão Registro de Mediadores, contendo relação atualizada de todos os mediadores habilitados a atuar prévia ou incidentalmente no âmbito do Estado. Na mediação judicial, a fiscalização e controle da atuação do mediador será feita pela Ordem dos Advogados do Brasil, por intermédio de suas seccionais. Se a mediação for incidental, a fiscalização também caberá ao juiz da causa.

Ainda de acordo com estes projetos de lei, as partes deverão estar acompanhadas de seus advogados nas sessões de mediação. Não tendo o requerido advogado constituído, o mediador solicitará à Defensoria Pública ou, na falta desta, à $\mathrm{OAB}$ a designação de dativo. Na impossibilidade de pronto atendimento à solicitação, o mediador imediatamente remarcará a sessão, deixando os interessados já cientificados da nova data e da indispensabilidade dos advogados.

Tais projetos divergem em relação a alguns pontos que continuam polêmicos no debate acerca da institucionalização da mediação. O primeiro deles é a obrigatoriedade ou facultatividade da mediação, prévia ou incidental, e o outro é a forma de pagamento da remuneração dos mediadores, assim como a fiscalização de sua atuação.

Sobre a remuneração, registro e controle de sua atuação, a Resolução $\mathrm{n}^{\circ} 125$ do Conselho Nacional de Justiça, de 29/11/2010, que será analisada no item a seguir, criou os Núcleos Permanentes de Métodos Consensuais de Solução de Conflitos e determinou que cabe aos mesmos criar e manter cadastro dos mediadores e conciliadores (para controlar o processo de inscrição e desligamento) e regulamentar, se for o caso, a sua remuneração, nos termos da legislação específica. Sendo necessária lei específica sobre o tema, ainda está distante o horizonte de uma atividade remunerada dos mediadores e conciliadores.

O Anteprojeto do novo Código de Processo Civil, elaborado por uma comissão de juristas instituída pelo ato do Presidente do Senado Federal no 379, de 2009, também trata de 
mediação e conciliação, cujo texto ora analisado é o que foi apresentado ao Senado como substitutivo ao projeto original, em novembro de 2010, pelo Senador Valter Pereira (Projeto de Lei $\left.n^{\circ} 166 / 2010\right)$.

O Projeto de Lei determina que cada Tribunal pode criar setor de conciliação e mediação ou programas destinados a estimular a autocomposição, sendo informados pelos princípios da independência, neutralidade, autonomia da vontade, confidencialidade, oralidade e informalidade.

Ao determinar que a realização de conciliação ou mediação deve ser estimulada por magistrados, advogados, defensores públicos e membros do Ministério Público, inclusive no curso do processo judicial, traça uma sucinta distinção entre conciliação e mediação nos parágrafos do art. 145:

$\S 1^{\circ} \mathrm{O}$ conciliador poderá sugerir soluções para o litígio, sendo vedada a utilização de qualquer tipo de constrangimento ou intimidação para que as partes conciliem. $\S 2^{\circ} \mathrm{O}$ mediador auxiliará as pessoas interessadas a compreenderem as questões e os interesses envolvidos no conflito e posteriormente identificarem, por si mesmas, alternativas de benefício mútuo.

O primeiro Anteprojeto determinava que os mediadores fossem necessariamente advogados, indo de encontro à realidade já existente em que a formação interdisciplinar desses profissionais é tida como um ponto favorável à solução de conflitos. O substitutivo apresentado posteriormente mudou isso, determinando, por outro lado, que os conciliadores e mediadores advogados, se inscritos na Ordem dos Advogados do Brasil, fiquem impedidos de exercer a advocacia nos limites da competência do respectivo tribunal e de integrar escritório de advocacia que o faça. $\mathrm{O}$ conciliador e o mediador ficam também impedidos, pelo prazo de um ano contado a partir do término do procedimento, de assessorar, representar ou patrocinar qualquer dos litigantes.

Referido Projeto de Lei também dispôs sobre a remuneração da atividade, prevista em tabela fixada pelo tribunal, conforme parâmetros estabelecidos pelo Conselho Nacional de Justiça, além de outras questões relacionadas, por exemplo, ao cadastro de mediadores e conciliadores mantidos pelos Tribunais, à sua capacitação mínima, às hipóteses de exclusão do registro e afastamento de conciliadores e mediadores, dentre outras. Determinou, por fim, que estas regras não excluem outras formas de conciliação e mediação extrajudiciais 
vinculadas a órgãos institucionais ou realizadas por intermédio de profissionais independentes.

Em termos de normatização judiciária, por sua vez, há os provimentos dos Tribunais regulando os setores de mediação e conciliação, o que se verificou na pesquisa empírica, principalmente nos Estados de São Paulo e do Rio de Janeiro.

Em São Paulo, os setores de conciliação e mediação pesquisados têm por base a autorização e suporte conferidos pelo Provimento $n^{0}$ 953/2005, do Conselho Superior da Magistratura (CSM) do Estado de São Paulo, que "autoriza e disciplina a criação, instalação e funcionamento do Setor de Conciliação ou de Mediação nas Comarcas e Foros do Estado",303. Em segunda instância, foi criado anteriormente o Plano Piloto de Conciliação pelo Provimento CSM 783/2002, que, em 25.03.2004, foi transformado em Setor de Conciliação em Segundo Grau do TJSP, com a estrutura determinada pela Portaria $n^{\circ} 7177 / 2004$, de acordo com o Provimento $n^{0} 843 / 2004$.

Tais provimentos tiveram por objetivo regular e uniformizar os procedimentos para instalação e as condições de funcionamento dos setores de conciliação nos diversos Fóruns e Comarcas do Estado de São Paulo, além de fomentar os meios autocompositivos para as questões cíveis que versem sobre direitos patrimoniais disponíveis, questões de família, da infância e juventude.

De acordo com o Provimento $n^{0}$ 953/2005, a efetiva instalação e início de funcionamento dos Setores de Conciliação e Mediação devem ser comunicados ao Conselho Superior da Magistratura ( $\operatorname{art} .1^{\circ}, \S 1^{\circ}$ ) e, uma vez instalados os setores, todos os magistrados das respectivas áreas envolvidas nele terão participação (art. $1^{\circ}, \S 2^{\circ}$ ). Os conciliadores atuarão sob orientação dos magistrados coordenadores e demais juízes das varas envolvidas com o Setor, e deverão submeter-se a cursos preparatórios e de reciclagem.

\footnotetext{
${ }^{303}$ Este provimento foi criado a partir dos bons resultados produzidos com o gerenciamento de demandas e inserção de técnicas de mediação, a título experimental, em $1^{\mathrm{a}}$ e $2^{\mathrm{a}}$ instâncias, no Foro Central, Regional e nas Comarcas do Interior. Ele substituiu os provimentos $n^{\circ}$ s 796/03 e 843/2004 anteriores, assim como as autorizações da Corregedoria Geral de Justiça (Processos GAJ 3 n. 140/2001 e CG n. 2782/2001) e do Conselho Superior da Magistratura (CG n. 502/2003) que autorizavam a atuação de conciliadores e mediadores nas audiências realizadas pelo juiz.
} 
Ainda no Provimento $n^{\circ}$ 953/2005 há a previsão tanto da conciliação pré-processual quanto da conciliação processual. Sobre a pré-processual, antes do ajuizamento de qualquer ação, o provimento determina que "comparecendo o interessado diretamente, encaminhado através do Juizado Especial Cível ou pelo Ministério Público na atividade de atendimento ao público, o funcionário ou voluntário do Setor de Conciliação colherá sua reclamação, sem reduzi-la a termo, emitindo, no ato, carta-convite à parte contrária, informativa da data, horário e local da sessão de conciliação, facultada, ainda, a solicitação por meio de representante legal" $\left(\operatorname{art} .4^{\circ}, \S^{\circ}\right)$.

A conciliação pré-processual também está prevista no Provimento CSM nº 1077/2006 que, considerando a possibilidade de serem desenvolvidas parcerias com entidades públicas e privadas para a ampliação e agilização dos serviços jurisdicionais, estabelece as Unidades Avançadas de atendimento. Uma delas, que existe em parceria com a Associação Comercial de São Paulo e com o Simpi - Sindicato da Micro e Pequena Indústria, localizada no bairro da Liberdade, na cidade de São Paulo, foi objeto da pesquisa empírica realizada neste trabalho.

As Unidades Avançadas foram inicialmente pensadas para propiciar o atendimento judiciário em locais estratégicos e em bairros, distritos e municípios distantes dos fóruns e juizados existentes, sendo firmados convênios entre o Tribunal de Justiça e os entes públicos ou privados interessados no serviço. Conforme determina o Provimento $n^{\circ} 1077 / 2006$, estas Unidades Avançadas de atendimento têm competência para recepcionar e processar pedidos de alimentos e pedidos da competência dos Juizados Informais de Conciliação e dos Juizados Especiais, sem prejuízo da instalação de unidades especializadas em matéria de trânsito, condomínios, microempresas e outras.

O conveniado é responsável pela disponibilização e manutenção do espaço físico, móveis, equipamentos, material de consumo e, ao menos, um funcionário e seu substituto eventual; enquanto o Tribunal é responsável por implementar o serviço através da seleção e treinamento de conciliadores, além da direção dos trabalhos pelo Juiz designado.

Quanto à conciliação processual, uma vez ajuizada a ação, fica a critério do juiz que preside o feito, a qualquer tempo, inclusive na fase do art. 331 do Código de Processo Civil, determinar, por despacho, o encaminhamento dos autos ao Setor de Conciliação, visando a tentativa de solução amigável do litígio. 
O Provimento $n^{\circ}$ 953/2005 recomenda a adoção desta providência, preferencialmente, após o recebimento da petição inicial, determinando a citação do réu e sua intimação, por mandado ou carta, para comparecimento à audiência no Setor de Conciliação, constando do mandado ou carta que o prazo para apresentação da resposta começará a fluir a partir da data da audiência se, por algum motivo, não for obtida a conciliação. Para a audiência serão intimados, também, os advogados das partes, pela imprensa ou outro meio de comunicação certificado nos autos.

Havendo o acordo, nas fases processual ou pré-processual, ele é reduzido a termo, assinado pelas partes, advogados e conciliador, ouvido o Ministério Público, nas hipóteses em que necessária sua intervenção, na própria sessão ou em dois dias, e homologado por um dos juízes das Varas abrangidas pelo setor, ou, no impedimento, por qualquer dos juízes em exercício na Comarca ou Fórum, valendo como título executivo judicial.

No Rio de Janeiro, o modelo de regulação é parecido com o de São Paulo, embora seja mais recente. A Resolução do TJRJ no 19, de 17.12.2009, regulamentou a atividade de mediação no âmbito do Poder Judiciário do Estado do $\mathrm{RJ}^{304}$, e atos executivos do Presidente do TJRJ criaram os Centros de Mediação. O ato executivo $n^{\circ} 5555 / 2009$ criou o Centro de Mediação do Fórum Central e, posteriormente, o ato executivo $n^{\circ}$ 1597/2010 criou outros Centros de Mediação em fórum regionais e comarcas do Rio de Janeiro.

Segundo esta Resolução, o Presidente do Tribunal poderá criar Centros de Mediação, compostos por um juiz coordenador e por, no mínimo, quatro mediadores, devidamente certificados, podendo extingui-los somente depois de ouvido o Órgão Especial. Determina ainda que nos projetos de construção e/ou reforma de edifícios dos Fóruns Estaduais seja necessariamente previsto e preservado espaço para montagem de Centro de Mediação. Anteriormente, a mediação já era aplicada pelos Juízes em suas varas, com a ajuda de mediadores voluntários, mas isso dependia da iniciativa e liberalidade de cada juiz.

Em nível nacional, o Ministério da Justiça propiciou a organização de um manual de mediação judicial, em 2009, resultado de esforço iniciado anteriormente pelo Grupo de

\footnotetext{
${ }^{304} \mathrm{O}$ anteprojeto da resolução foi apresentado pelo Grupo de Trabalho de Soluções Alternativas para Busca de Resolução de Conflitos do Tribunal de Justiça do Estado do Rio de Janeiro, tendo tramitado no Órgão Especial deste Tribunal.
} 
Pesquisa e Trabalho em Resolução Apropriada de Disputas da Faculdade de Direito da Universidade de Brasília (FD/UnB). Neste manual há uma sequência de passos, técnicas e ferramentas a serem seguidos e adotados pelos mediadores que atuam no âmbito do Poder Judiciário em demandas cíveis e que, com algumas alterações, poderiam ser utilizados também por conciliadores.

O manual é formado por 4 seções. Na primeira, apresenta uma visão geral do processo de mediação e de seu posicionamento dentre as formas de resolução de conflito. A segunda seção busca explicar detidamente cada uma das fases do processo de mediação. Em sequência, são desenvolvidas as técnicas necessárias à condução da mediação (terceira seção), e a última seção aborda os aspectos relacionados à administração por tribunais de justiça de programas de mediação - como a gestão de qualidade e componentes pedagógicos relacionados à mediação ${ }^{305}$.

\section{c) Políticas Judiciárias nacionais sobre a mediação e conciliação}

Considerando a função de planejamento estratégico do Poder Judiciário atribuída pela Constituição Federal de 88 (art. 103-B) ao Conselho Nacional de Justiça, que foi criado através da Reforma promovida pela Emenda Constitucional $n^{\circ} 45$ e com a função de exercer o controle externo da atividade jurisdicional, uma série de políticas judiciárias voltadas ao estabelecimento de metas de produtividade e à conciliação têm sido capitaneadas pelo CNJ, com efeitos nos tribunais estaduais e federais de todo o país. O Movimento pela Conciliação, que teve início em 23.08.2006, é um exemplo disso. Naquele mesmo ano, o dia 8 de dezembro foi dedicado à mobilização do Dia Nacional pela Conciliação. A primeira Semana Nacional pela Conciliação ocorreu no ano seguinte, em 2007, de 03 a 08 de dezembro ${ }^{306}$.

Para consolidar o Movimento pela Conciliação, foi editada pelo CNJ a Recomendação $\mathrm{n}^{\mathrm{o}} 8$, de 27.02.2007, que sugere aos tribunais o planejamento e a viabilização de atividades conciliatórias. Ela recomenda aos Tribunais de Justiça, Tribunais Regionais Federais e

\footnotetext{
${ }^{305}$ BRASIL, Manual de Mediação Judicial cit.

306 http://www.cnj.jus.br/index.php?option=com_content\&view=article\&id=7932\&Itemid=973. Acesso em 20/12/2010.
} 
Tribunais Regionais do Trabalho a realização de estudos e de ações tendentes a dar continuidade ao Movimento pela Conciliação, com planejamento anual, a preparação de semanas e do dia nacional da conciliação, a definição de metas, a realização de pesquisas, dentre outras atividades.

Em 2010, foi criado o primeiro prêmio "Conciliar é legal", instrumento para identificar, premiar e disseminar boas e inovadoras práticas autocompositivas que estejam contribuindo para a pacificação de conflitos bem como para a modernização, rapidez e eficiência da Justiça Brasileira. Os temas deste ano foram: Paz Duradoura, Conciliação Préprocessual, Semana Nacional da Conciliação, valendo para as categorias Tribunal e Juiz Individual.

Essas iniciativas culminaram com a recente Resolução $\mathrm{n}^{\circ} 125$ do CNJ, de 29.11.2010, que instituiu a Política Judiciária Nacional de tratamento adequado dos conflitos de interesses no âmbito do Judiciário, como forma de assegurar a conciliação e a mediação em todo o país. A resolução considera que cabe ao Judiciário estabelecer política pública de tratamento adequado dos problemas jurídicos e dos conflitos de interesses, que ocorrem em larga e crescente escala na sociedade, de forma a organizar, em âmbito nacional, não somente os serviços prestados nos processos judiciais, como também os que possam sê-lo mediante outros mecanismos de solução de conflitos, em especial dos consensuais, como a mediação e a conciliação ${ }^{307}$.

De acordo com esta resolução, compete ao Conselho Nacional de Justiça organizar programa com o objetivo de promover ações de incentivo à autocomposição de litígios, a ser implementado com a participação de rede constituída por todos os órgãos do Poder Judiciário e por entidades públicas e privadas parceiras, inclusive universidades e instituições de ensino.

Duas das novidades a serem implantadas por meio da Resolução $n^{0}$ 125/2010 são a criação de Núcleos Permanentes de Métodos Consensuais de Solução de Conflitos e a instalação de Centros Judiciários de Solução de Conflitos e Cidadania para atender aos Juízos, Juizados ou Varas com competência nas áreas cível, fazendária, previdenciária, de família ou

\footnotetext{
${ }^{307}$ A resolução $n^{\circ}$ 125, de 29/11/2010, que dispõe sobre a Política Judiciária Nacional de tratamento adequado dos conflitos de interesse no âmbito do Poder Judiciário e dá outras providências, está disponível no site www.cnj.jus.br Acesso em 20/12/2010.
} 
dos Juizados Especiais Cíveis e Fazendários. Os Núcleos devem ser criados pelos tribunais dentro de 30 dias da publicação da Resolução. Já em relação aos Centros Judiciários, o CNJ estabeleceu prazo de quatro a doze meses para que sejam instalados. Cada unidade dos Centros Judiciários deverá abranger setor de conciliação de conflitos pré-processual, processual e setor de cidadania, contando com um Juiz Coordenador, designado pelo Presidente do Tribunal, a quem caberá a administração do centro e supervisão do serviço de conciliadores e mediadores, e onde poderão atuar também membros do Ministério Público, Defensores, Procuradores e Advogados.

Um dos focos dessa resolução é criar uma disciplina mínima e uniforme para a prática dos meios consensuais de solução de conflitos no Judiciário, que funcionam como um importante filtro da litigiosidade, além de estimular em nível nacional a cultura da pacificação social, estabelecendo diretrizes para implantação de políticas públicas que tracem caminhos para um tratamento adequado de conflitos.

Dentre estas diretrizes, estão: i. desenvolvimento de conteúdo programático mínimo e ações voltadas à capacitação em métodos consensuais de solução de conflitos, para servidores, mediadores, conciliadores e demais facilitadores; ii. providenciar que as atividades relacionadas à conciliação, mediação e outros métodos consensuais de solução de conflitos sejam consideradas nas promoções e remoções de magistrados pelo critério do merecimento; iii. regulamentação, em código de ética, da atuação dos conciliadores, mediadores e demais facilitadores; iv. cooperação dos órgãos públicos competentes e das instituições públicas e privadas da área de ensino, para a criação de disciplinas que propiciem o surgimento da cultura da solução pacífica dos conflitos, inclusive nas Escolas de Magistratura; v. estabelecer interlocução com a Ordem dos Advogados do Brasil, Defensorias Públicas, Procuradorias e Ministério Público, estimulando sua participação nos Centros Judiciários de Solução de Conflitos e Cidadania e valorizando a atuação na prevenção dos litígios; vi. realizar gestão junto às empresas e às agencias reguladoras de serviços públicos, a fim de implementar práticas autocompositivas e desenvolver acompanhamento estatístico, com a instituição de banco de dados para visualização de resultados, conferindo selo de qualidade; vii. atuar junto aos entes públicos de modo a estimular a conciliação nas demandas que envolvam matérias sedimentadas pela jurisprudência (art. $6^{\circ}$ da Resolução $n^{\circ}$ 125/2010) 
Importante destacar, ainda, que o disposto nesta resolução não prejudica a continuidade de programas já em funcionamento, conforme ressalva o seu art. 16, sendo facultado aos Tribunais a adaptação dos programas ao estabelecido pela resolução.

Assim, percebe-se que a conciliação é vista atualmente como uma medida de gestão do Judiciário, relacionada às recomendações e metas definidas pelo CNJ junto às Presidências dos Tribunais Brasileiros. Algumas vezes, as atuações são planejadas em relação aos litigantes habituais e ao contencioso de massa, através de mutirões de conciliação voltados às Prestadoras de serviços públicos, Sistema Financeiro de Habitação, Bancos, dentre outros.

Os números das semanas de conciliação impressionam, conforme revela a tabela abaixo com a soma de acordos nos Tribunais de todo o país. Contudo, é preciso ter o cuidado de associar o aspecto quantitativo ao qualitativo, este último referente à qualidade e ao cumprimento dos acordos, o que não é ainda mensurado nas estatísticas disponíveis sobre os meios autocompositivos.

Tabela 3. Dados estatísticos das Semanas de Conciliação no Judiciário.

\begin{tabular}{l|c|c|c|c}
\hline Semanas da Conciliação & $\mathbf{2 0 0 6}$ & $\mathbf{2 0 0 7}$ & $\mathbf{2 0 0 8}$ & $\mathbf{2 0 0 9}$ \\
\hline Audiências designadas & 112.112 & 303.638 & 398.012 & 431.616 \\
\hline Audiências realizadas & 83.987 & 227.564 & 305.591 & 330.081 \\
\hline Acordos efetuados & 46.493 & 96.492 & 135.337 & 148.605 \\
\hline Valores & - & 375 milhões & 974 milhões & $\begin{array}{c}1 \text { bilhão e } \\
277 \text { milhões }\end{array}$ \\
\hline Pessoas Atendidas & - & 411 mil & 633 mil & 620 mil \\
\hline
\end{tabular}

Fonte: DPJ-CNJ

A pesquisa sobre "Acesso à Justiça por Sistemas Alternativos de Administração de Conflitos: mapeamento nacional de programas públicos e não governamentais", já abordada no capítulo 3, também aponta algumas diretrizes para subsidiar a formulação de política pública para esta área, abaixo transcritas ${ }^{308}$ :

- Criação de banco de dados: a fim de maximizar a efetividade e capilaridade dos programas de solução alternativa de conflitos já existentes, devem ser adotadas medidas para articulação destes em rede. Há de ser fomentada a criação de um

\footnotetext{
${ }^{308}$ BRASIL. Ministério da Justiça. Acesso à Justiça por Sistemas Alternativos de Administração de Conflitos cit., pp. 53-55.
} 
banco de dados, atualizável e auto-alimentável.

- Integração interinstitucional: devem ser discutidos e implementados mecanismos de integração interinstitucional, devendo-se ponderar sobre a criação de um colegiado congregando os atores governamentais, que atuam direta ou indiretamente na área, a fim de se avançar na construção de uma política pública coordenada que contemple a adoção de critérios mínimos para a concessão de apoio financeiro, bem como minimize a sobreposição de esforços.

- Troca de informações: devem ser promovidos encontros ou seminários com os coordenadores dos programas existentes para viabilizar a troca de informações e integração das experiências. Deve-se também instituir como critérios para o apoio aos programas a transparência e o compartilhamento de métodos, custos e resultados.

- Avaliação dos programas: deve-se estimular a criação de critérios e procedimentos voltados à avaliação técnica e qualitativa dos programas apoiados, com o objetivo de aperfeiçoá-los e favorecer sua convergência a um conjunto homogêneo mínimo de princípios, conceitos, metodologias de trabalho, objetivos e resultados esperados.

- Capacitação: é imprescindível o estímulo à capacitação e à educação permanente das equipes dos programas, ainda que incluindo tais aspectos como critério de seleção e avaliação de projetos a serem apoiados. As ações de capacitação devem abranger a organização de manuais que disseminem conhecimentos e auxiliem na avaliação interna dos programas. Deve-se estimular a multidisciplinaridade e a interdisciplinaridade na oferta de serviços alternativos de administração de conflitos.

- Remuneração e Profissionalização: Deve-se discutir formas e modelos de remuneração, como importante fator de engajamentos duradouros e de profissionalização dos programas, sem prejuízo da discussão de táticas de engajamento de voluntariado, em parceria com empresas e organizações socialmente responsáveis.

- Papel das Universidades: deve-se estimular o engajamento das universidades na formação de novos profissionais capacitados para atuar nos sistemas alternativos de administração de conflitos, seja na oferta de disciplinas teóricas, de disciplinas práticas, seja na organização de campos de estágio, seja com atividades de 
extensão universitária. Deve-se estimular a participação das universidades na avaliação dos programas.

- Participação: deve-se incentivar os diversos entes governamentais do Poder Executivo a fazerem uso de sistemas alternativos de administração de conflitos. Em razão da natureza de suas atribuições, a Defensoria Pública deve ser instada a investir em sistemas alternativos de administração de conflitos junto ao público por ela atendido. Deve ser discutida a possibilidade de estímulo ao investimento privado nos programas que não contem com parceria governamental e deve-se estimular a participação da sociedade civil local, seja através do engajamento de membros da comunidade destinatária nas equipes dos projetos (modelo da mediação comunitária), seja por outras formas de participação a serem contempladas.

\subsection{Pesquisa empírica dos Programas de Mediação}

\section{a) Justificativa para a escolha dos programas de mediação}

Para a realização da pesquisa empírica sobre programas de mediação e conciliação no Brasil, foram escolhidos os seguintes programas:

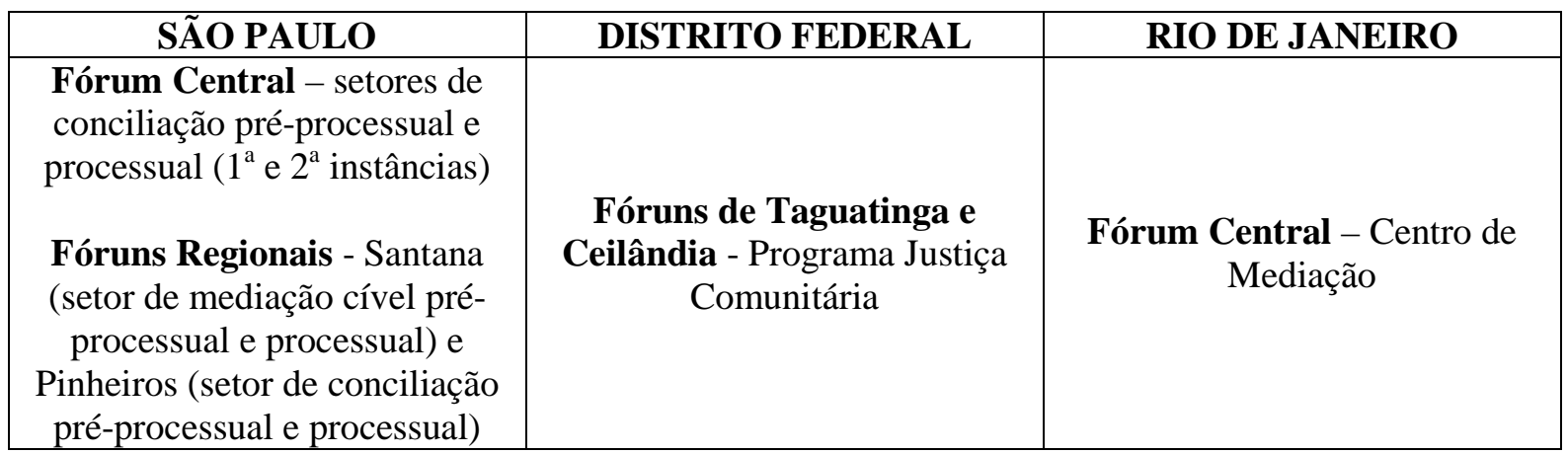

Essas escolhas se justificaram pela diversidade de características dos programas: (i) programas de conciliação e mediação; (ii) pré-processuais e processuais; (iii) em $1^{\mathrm{a}}$ e $2^{\mathrm{a}}$ instâncias; (iv) ligados aos Fóruns Centrais ou Regionais; (v) nas áreas cível ou de família; 
(vi) no âmbito judicial e comunitário; e (vii) com diferentes níveis de regulação e institucionalização.

Percebeu-se na pesquisa que alguns setores de conciliação convivem separadamente dos setores de mediação no mesmo Tribunal ${ }^{309}$ e que os setores de conciliação se estruturam e estão mais preparados para a litigância repetitiva e de massa, enquanto os setores de mediação trabalham com um volume mais reduzido e foco na relação continuada, normalmente atendendo casos de direito de família.

Os setores de conciliação e mediação pesquisados atuam nas fases pré-processual e processual, com exceção do Setor de Conciliação em segunda instância do TJSP (que não atua em fase pré-processual) e do Programa de Justiça Comunitária no TJDF, destacando-se este último dos demais por ser um programa estritamente comunitário, sendo realizada a mediação por agentes comunitários e sem qualquer relação com o Judiciário, apesar do apoio institucional que o programa recebe do Tribunal e do Ministério da Justiça.

Este Programa de Justiça Comunitária existe ao lado de outros programas no TJDF: o programa de mediação forense (SERMEC - Serviço de Mediação Forense e Cível) ${ }^{310}$, a Justiça Restaurativa, a Central do Idoso e os Setores de Conciliação dos Juizados Especiais. São programas independentes e que contam com a participação de diferentes juízes e funcionários, muito embora em 2009 tenha sido criada uma coordenação geral - a Coordenação do Sistema Múltiplas Portas, que engloba todos estes programas, com exceção do setor de Conciliação do JEC.

O Programa de Justiça Comunitária atua em três frentes: 1. educação para os direitos (esclarecimentos dos direitos dos cidadãos, com base em materiais didáticos e artísticos produzidos pelos agentes comunitários no programa); 2. mediação comunitária (ferramenta de empoderamento e emancipação social); 3. animação de redes sociais (mobilização social de pessoas e instituições, em rede, para que encontrem juntas uma solução aos conflitos).

\footnotetext{
${ }^{309}$ É o que acontece, por exemplo, nos Fóruns de Pinheiros, de Santo Amaro e de Santana em São Paulo, onde os setores de conciliação estão separados dos setores de mediação de conflitos (no caso de Santana, o setor de mediação já está implantado, e o de conciliação está ainda em formação).

${ }^{310}$ Este programa se assemelha aos demais setores de conciliação e mediação objeto da pesquisa empírica, mas não se obteve resposta dos coordenadores quanto ao agendamento de visitas e realização de entrevistas, razão pela qual não foi escolhido para compor a pesquisa empírica deste trabalho.
} 
O projeto surgiu no interior de um ônibus especialmente adaptado para a realização de audiências em comunidades do Distrito Federal com dificuldade de acesso à Justiça (levado adiante pela Juíza Glaucia Foley), entre os anos de 1999 e 2001. Sua oficialização resultou de iniciativa do TJDFT, em parceria com o Ministério Público do Distrito Federal, Defensoria Pública do Distrito Federal e a Faculdade de Direito da Universidade de Brasília (UnB). Contou com apoio da Secretaria Nacional de Segurança Pública (SENASP), da Secretaria de Reforma do Judiciário (SRJ-MJ) e do PNUD e atualmente está instalado nas cidades-satélites de Ceilândia e Taguatinga, além de contar com um novo núcleo na cidade satélite de Samambaia ${ }^{311}$.

A seguir, no quadro comparativo, são abordadas as principais características de cada um dos programas pesquisados em São Paulo, no Rio de Janeiro e no Distrito Federal.

${ }^{311}$ Uma descrição mais detalhada do Programa Justiça Comunitária pode ser encontrada na obra "Justiça Comunitária - uma experiência", disponível no site http://www.tjdft.jus.br/trib/prog/just/prog_jcdown.asp. Acesso em 20/12/2010. 
b) Quadros comparativos dos programas

\section{i. Características Gerais dos Programas}

\begin{tabular}{|c|c|c|c|c|c|c|}
\hline CIDADE & \multicolumn{4}{|c|}{ SÃO PAULO } & \multirow{2}{*}{$\begin{array}{c}\text { RIO DE JANEIRO } \\
\text { Centro de } \\
\text { Mediação Fórum } \\
\text { Central - setor } \\
\text { processual }\end{array}$} & \multirow{2}{*}{$\begin{array}{c}\text { DISTRITO } \\
\text { FEDERAL } \\
\text { Programa de } \\
\text { Justiça } \\
\text { Comunitária - } \\
\text { TJDF } \\
\end{array}$} \\
\hline PROGRAMA & $\begin{array}{c}\text { Fórum Central João } \\
\text { Mendes - } \\
\text { Conciliação } \\
\text { pré-processual, } \\
\text { processual }\end{array}$ & $\begin{array}{c}\text { TJSP - Conciliação } \\
2^{\mathrm{a}} \text { instância }\end{array}$ & $\begin{array}{l}\text { Fórum Regional } \\
\text { Pinheiros - } \\
\text { Conciliação pré- } \\
\text { processual e } \\
\text { processual }\end{array}$ & $\begin{array}{c}\text { Fórum Regional de } \\
\text { Santana - } \\
\text { Mediação pré- } \\
\text { processual e } \\
\text { processual }\end{array}$ & & \\
\hline $\begin{array}{l}\text { Ano em que } \\
\text { foi } \\
\text { implementada } \\
\text { a mediação / } \\
\text { conciliação no } \\
\text { Judiciário }\end{array}$ & $\begin{array}{l}\text { Em } \mathbf{0 8 . 0 9 . 2 0 0 4 , ~ e m ~} \\
\text { caráter experimental, } \\
\text { foi criado o setor } \\
\text { processual de } \\
\text { conciliação. Em jan. } \\
\text { de } 2005 \text {, o setor pré- } \\
\text { processual. Após o } \\
\text { provimento CSM } \\
\text { 953/2005, o setor } \\
\text { processual passou a } \\
\text { contar com Cartório } \\
\text { que serve a todas as } \\
\text { Varas Cíveis do } \\
\text { Fórum. }\end{array}$ & $\begin{array}{l}\text { O setor começou a } \\
\text { funcionar em } \\
\mathbf{2 6 . 0 3 . 2 0 0 3 , ~ e m ~} \\
\text { caráter } \\
\text { experimental, de } \\
\text { acordo com o } \\
\text { provimento CSM } \\
\text { 783/2002, e, em } \\
25.03 .2004, \text { foi } \\
\text { transformado em } \\
\text { Setor de Conciliação } \\
\text { em Segundo Grau } \\
\text { do TJSP, de acordo } \\
\text { com a Portaria } \\
\text { 7177/2004 e o } \\
\text { Provimento } \\
\text { 843/2004. }\end{array}$ & $\begin{array}{c}\text { Em 18.02.2008. O } \\
\text { setor começou a ser } \\
\text { montado em dez. } \\
\text { de } 2007 \text {. Até maio } \\
\text { de } 2010 \text { não havia } \\
\text { sido criada a } \\
\text { estrutura } \\
\text { administrativa do } \\
\text { setor (o Cartório } \\
\text { propriamente dito). } \\
\text { A partir de } \\
\text { 14/05/10 o TJSP } \\
\text { estruturou o Setor } \\
\text { em Unidade } \\
\text { Administrativa. }\end{array}$ & 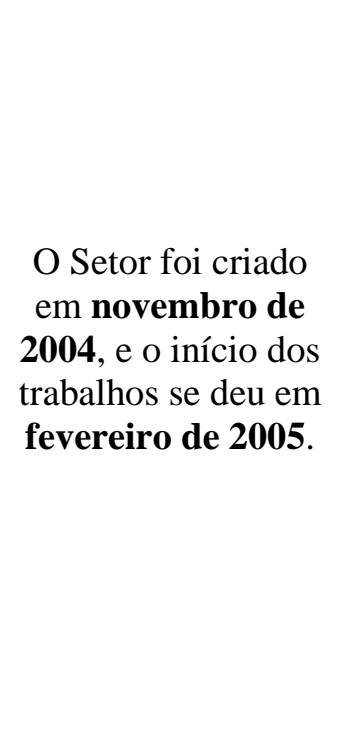 & $\begin{array}{l}\mathrm{O} \text { ato executivo } \mathrm{n}^{\circ} \\
5555 / 2009 \text { criou o } \\
\text { Centro de Mediação } \\
\text { do Fórum Central da } \\
\text { Comarca da Capital, } \\
\text { que passou a } \\
\text { funcionar a partir de } \\
\mathbf{1 0 . 1 2 . 2 0 0 9} .\end{array}$ & $\begin{array}{c}\text { O Projeto Justiça } \\
\text { Comunitária nasceu } \\
\text { a partir da } \\
\text { experiência advinda } \\
\text { do Juizado Especial } \\
\text { Cível Itinerante do } \\
\text { TJDFT, em 1999, e } \\
\text { foi oficialmente } \\
\text { criado em outubro } \\
\text { de } \mathbf{2 0 0 0 .}\end{array}$ \\
\hline
\end{tabular}




\begin{tabular}{|c|c|c|c|c|c|c|}
\hline $\begin{array}{l}\text { Tipos de } \\
\text { conflito }\end{array}$ & $\begin{array}{c}\text { Conflitos envolvendo } \\
\text { vizinhança, cobrança, } \\
\text { relação de consumo. } \\
\text { No setor pré- } \\
\text { processual, há } \\
\text { principalmente casos } \\
\text { de renegociação de } \\
\text { dívida com cartão de } \\
\text { crédito, sob a } \\
\text { iniciativa do devedor. } \\
\text { Não podem ser } \\
\text { encaminhados aos } \\
\text { setores ações } \\
\text { criminais em geral, } \\
\text { inventário, interdição, } \\
\text { curatela. } \\
\text { O setor pré- } \\
\text { processual atende às } \\
\text { pessoas com } \\
\text { domicílio residencial } \\
\text { no Centro, salvo se } \\
\text { não houver setor de } \\
\text { conciliação no Fórum } \\
\text { de competência. }\end{array}$ & $\begin{array}{c}\text { Quaisquer casos } \\
\text { podem ser remetidos } \\
\text { ao setor, que, como } \\
\text { atende a todo } \\
\text { Estado, recebe casos } \\
\text { bem variados. O } \\
\text { único requisito é que } \\
\text { envolva direito } \\
\text { disponível. Os casos } \\
\text { mais comuns são } \\
\text { aqueles em maior } \\
\text { volume no Tribunal, } \\
\text { sobre contratos } \\
\text { bancários e compra } \\
\text { e venda de imóveis, } \\
\text { por exemplo. }\end{array}$ & $\begin{array}{l}\text { No setor processual } \\
\text { são comuns } \\
\text { conflitos de } \\
\text { vizinhança, ações } \\
\text { de cobrança } \\
\text { (instituição } \\
\text { financeira, escola), } \\
\text { relações de } \\
\text { consumo, } \\
\text { condomínio, } \\
\text { despejo, seguro, } \\
\text { direito de família, } \\
\text { alimentos, dentre } \\
\text { outros. O setor pré- } \\
\text { processual é } \\
\text { bastante procurado } \\
\text { pelo devedor para } \\
\text { renegociação de } \\
\text { dívida de cartão de } \\
\text { crédito e por } \\
\text { conflitos entre } \\
\text { vizinhos. O pré- } \\
\text { processual atende } \\
\text { às pessoas com } \\
\text { domicílio } \\
\text { residencial em } \\
\text { Pinheiros. }\end{array}$ & $\begin{array}{l}\text { Predominantemente } \\
\text { relações de família, } \\
\text { mas há também } \\
\text { casos cíveis } \\
\text { envolvendo } \\
\text { vizinhança, ações de } \\
\text { cobrança, relações } \\
\text { de consumo, } \\
\text { dissolução de } \\
\text { sociedade, extinção } \\
\text { de condomínio, } \\
\text { dentre outros. No } \\
\text { setor pré-processual, } \\
\text { os conflitos mais } \\
\text { comuns são os de } \\
\text { família e vizinhança. }\end{array}$ & $\begin{array}{c}\text { Relações de família, } \\
\text { principalmente } \\
\text { questões envolvendo } \\
\text { alimentos e guarda, } \\
\text { pois de acordo com } \\
\text { o ato executivo } \\
5555 / 2009 \text {, o Centro } \\
\text { de Mediação do } \\
\text { Fórum Central tem } \\
\text { competência para } \\
\text { atender aos casos } \\
\text { encaminhados pelos } \\
\text { Juízes de Direito das } \\
\text { Varas de Família da } \\
\text { Comarca da Capital. }\end{array}$ & $\begin{array}{c}\text { Relações de família, } \\
\text { pensão alimentícia } \\
\text { (maior parte, } 46 \% \text { ), } \\
\text { vizinhança, moradia, } \\
\text { habitação, relações } \\
\text { de consumo. Casos } \\
\text { relativos a questões } \\
\text { criminais não podem } \\
\text { ser remetidos à } \\
\text { mediação. } \\
\text { Muitos casos que } \\
\text { poderiam ir ao JEC } \\
\text { chegam ao programa } \\
\text { de justiça } \\
\text { comunitária. }\end{array}$ \\
\hline $\begin{array}{c}\text { Mediação } \\
\text { (obrigatória } \\
\text { ou voluntária) }\end{array}$ & Voluntária & Voluntária & Voluntária & $\begin{array}{l}\text { É obrigatória para } \\
\text { conhecer o trabalho, } \\
\text { e voluntária para } \\
\text { participar do mesmo }\end{array}$ & Voluntária & Voluntária \\
\hline Regulação & Provimento CSM & Provimento CSM & Provimento CSM & Provimento CSM & Resolução do TJ no & $\mathrm{ND}^{313}$ \\
\hline
\end{tabular}

${ }^{312}$ Obrigatória é entendida aqui no sentido de a presença ser obrigatória na sessão de mediação ( $g$ et to the table), e não de necessariamente se fechar um acordo. 


\begin{tabular}{|c|c|c|c|c|c|c|}
\hline (due process) & $\begin{array}{l}\text { 953/2005. Além deste } \\
\text { provimento, há } \\
\text { ordens de serviço que } \\
\text { podem ser exaradas } \\
\text { pelos Juízes } \\
\text { Coordenadores do } \\
\text { Setor sobre questões } \\
\text { de rotina. }\end{array}$ & $\begin{array}{c}\text { 843/2004 e Portaria } \\
7177 / 2004 .\end{array}$ & 953/2005. & $\begin{array}{c}\text { 953/2005. Há } \\
\text { também o projeto de } \\
\text { implantação do } \\
\text { Setor de Mediação } \\
\text { de Santana, } \\
\text { aprovado em } \\
\text { dezembro de } 2004 .\end{array}$ & $\begin{array}{l}\text { 19, de } 17.12 .2009, \\
\text { que regulamentou a } \\
\text { atividade de } \\
\text { mediação no âmbito } \\
\text { do Poder Judiciário } \\
\text { do Estado do RJ e } \\
\text { ato executivo no } \\
5555 / 2009, \text { que } \\
\text { criou o Centro de } \\
\text { Mediação do Fórum } \\
\text { Central }\end{array}$ & \\
\hline $\begin{array}{l}\text { Estrutura do } \\
\text { Setor }\end{array}$ & $\begin{array}{c}\text { Há um juiz } \\
\text { coordenador dos } \\
\text { setores de conciliação } \\
\text { pré-processual e } \\
\text { processual, indicado } \\
\text { pela Presidência do } \\
\text { Tribunal por um } \\
\text { período } \\
\text { indeterminado } \\
\text { setor pré-processual } \\
\text { pesquisado, os } \\
\text { funcionários são } \\
\text { cedidos pela } \\
\text { Associação } \\
\text { Comercial de SP. No } \\
\text { setor processual, o } \\
\text { quadro do Cartório é } \\
\text { composto por uma }\end{array}$ & $\begin{array}{c}\text { Há servidores } \\
\text { lotados no Setor e } \\
\text { um Diretor. De } \\
\text { acordo com a } \\
\text { portaria } 7177 / 2004, \\
\text { há ainda um setor de } \\
\text { apoio à Conciliação } \\
\text { em Segundo Grau, } \\
\text { subordinado } \\
\text { diretamente ao } \\
\text { Gabinete da } \\
\text { Presidência do } \\
\text { Tribunal de Justiça, } \\
\text { com uma Diretoria } \\
\text { de Divisão, formada } \\
\text { por } \\
\text { desembargadores } \\
\text { que coordenam o }\end{array}$ & $\begin{array}{c}\text { O setor, } \\
\text { atualmente, conta } \\
\text { com um juiz } \\
\text { coordenador, um } \\
\text { juiz adjunto, uma } \\
\text { diretora de divisão, } \\
\text { e três funcionários } \\
\text { emprestados de } \\
\text { outros setores. Está } \\
\text { se aguardando mais } \\
\text { dois escreventes } \\
\text { chefes. }\end{array}$ & $\begin{array}{c}\text { Há duas juízas } \\
\text { coordenadoras do } \\
\text { setor de mediação e } \\
\text { uma mediadora } \\
\text { coordenadora. O } \\
\text { Setor de Mediação } \\
\text { conta também com } 2 \\
\text { auxiliares. }\end{array}$ & $\begin{array}{l}\text { O Centro de } \\
\text { Mediação do Fórum } \\
\text { Central é dirigido } \\
\text { por Juiz de Vara de } \\
\text { Família nomeado } \\
\text { pela Presidência do } \\
\text { Tribunal de Justiça, } \\
\text { e conta com um } \\
\text { coordenador } \\
\text { (servidor do } \\
\text { Tribunal), secretária } \\
\text { e funcionários que } \\
\text { atuam no setor. }\end{array}$ & $\begin{array}{c}\text { Há duas juízas } \\
\text { coordenadoras, } \\
\text { uma Coordenadora } \\
\text { Adjunta, uma } \\
\text { supervisora } \\
\text { administrativa e } \\
\text { uma Diretora do } \\
\text { Centro de Formação. } \\
\text { Há três núcleos } \\
\text { comunitários de } \\
\text { justiça e cidadania } \\
\text { do Programa. Cada } \\
\text { núcleo conta com } \\
\text { uma equipe técnica } \\
\text { composta por três } \\
\text { servidores do } \\
\text { Tribunal (um } \\
\text { bacharel em direito, }\end{array}$ \\
\hline
\end{tabular}

\footnotetext{
${ }^{313}$ Resposta/Informação não disponível.

${ }^{314}$ Para que o juiz coordenador dos setores de conciliação consiga cumular as atividades de juiz e de coordenador, foi alocado mais um juiz na Vara em que atua.
} 


\begin{tabular}{|c|c|c|c|c|c|c|}
\hline & $\begin{array}{c}\text { Diretoria, duas } \\
\text { chefias, e escreventes } \\
\text { designados } \\
\text { especificamente para } \\
\text { o Setor. }\end{array}$ & setor. & & & & $\begin{array}{l}\text { um assistente social } \\
\text { e um psicólogo) }{ }^{315} \text {. }\end{array}$ \\
\hline $\begin{array}{c}\text { Custos para as } \\
\text { partes }\end{array}$ & $\begin{array}{l}\text { Sem custos para as } \\
\text { partes, quando o valor } \\
\text { da demanda é até de } \\
40 \text { salários mínimos. } \\
\text { Acima deste valor (e } \\
\text { até } 100 \text { salários } \\
\text { mínimos), haverá o } \\
\text { recolhimento de } \\
\text { custas no montante de } \\
1 \% \text { sobre o valor } \\
\text { acordado. }\end{array}$ & $\begin{array}{c}\text { Não há custos } \\
\text { específicos. Apenas } \\
\text { as custas normais do } \\
\text { processo. }\end{array}$ & $\begin{array}{l}\text { Sem custos para as } \\
\text { partes, quando o } \\
\text { valor da demanda é } \\
\text { de até } 40 \text { salários } \\
\text { mínimos. }\end{array}$ & $\begin{array}{c}\text { Não há custos para } \\
\text { as partes. }\end{array}$ & $\begin{array}{c}\text { Não há custos para } \\
\text { as partes. }\end{array}$ & $\begin{array}{c}\text { Não há custos para } \\
\text { as partes. }\end{array}$ \\
\hline $\begin{array}{c}\text { Recursos / } \\
\text { Fundos } \\
\text { destinados ao } \\
\text { programa }\end{array}$ & $\begin{array}{c}\text { Despesas são arcadas } \\
\text { pelo Judiciário e, no } \\
\text { caso do setor pré- } \\
\text { processual, há } \\
\text { convênio com a } \\
\text { Associação } \\
\text { Comercial de São } \\
\text { Paulo e o Sindicato } \\
\text { das Micro e Pequenas } \\
\text { Indústrias. }\end{array}$ & $\begin{array}{l}\text { Despesas são } \\
\text { arcadas pelo } \\
\text { Judiciário. }\end{array}$ & $\begin{array}{l}\text { Despesas são } \\
\text { arcadas pelo } \\
\text { Judiciário. }\end{array}$ & $\begin{array}{l}\text { Despesas são } \\
\text { arcadas pelo } \\
\text { Judiciário. }\end{array}$ & $\begin{array}{l}\text { Despesas são } \\
\text { arcadas pelo } \\
\text { Judiciário }\end{array}$ & $\begin{array}{l}\text { Parte das despesas } \\
\text { são arcadas pelo } \\
\text { Judiciário } \\
\text { (servidores alocados } \\
\text { no programa, } \\
\text { telefone, etc). } \\
\text { Os custos e despesas } \\
\text { dos agentes são } \\
\text { reembolsados } \\
\text { através de convênio } \\
\text { atualmente firmado } \\
\text { com o Ministério da } \\
\text { Justiça. }\end{array}$ \\
\hline $\begin{array}{l}\text { Volume de } \\
\text { casos - }\end{array}$ & $\begin{array}{c}\text { Grande. De } \\
\text { setembro/2004 até }\end{array}$ & $\begin{array}{l}\text { Grande. Por dia são } \\
\text { agendadas em média }\end{array}$ & $\begin{array}{c}\text { Grande. São } \\
\text { agendadas uma }\end{array}$ & $\begin{array}{c}\text { Médio. São } \\
\text { agendadas uma }\end{array}$ & ND & $\begin{array}{c}\text { Médio para } \\
\text { atendimentos sócio- }\end{array}$ \\
\hline
\end{tabular}

${ }^{315}$ Esta equipe (tríade) é responsável pela supervisão e orientação dos agentes comunitários. 


\begin{tabular}{|c|c|c|c|c|c|c|}
\hline 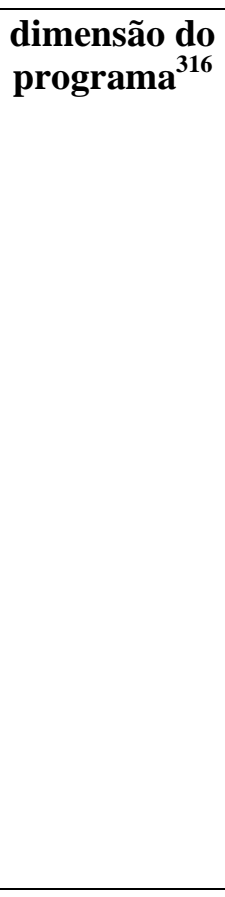 & $\begin{array}{c}\text { maio/2010 foram } \\
\text { remetidos ao Setor de } \\
\text { Conciliação } \\
\text { processual } 74.589 \\
\text { processos. No Setor } \\
\text { de Conciliação pré- } \\
\text { processual, de } \\
\text { janeiro/2005 a } \\
\text { maio/2010 houve a } \\
\text { entrada no setor de } \\
28.225 \text { expedientes } \\
\text { extraprocessuais. }^{317}\end{array}$ & $\begin{array}{c}24 \text { sessões de } \\
\text { conciliação, metade } \\
\text { para o turno da } \\
\text { manhã e metade } \\
\text { para a tarde, com } \\
\text { três mediadores em } \\
\text { cada turno (cada um } \\
\text { podendo fazer em } \\
\text { média } 4 \\
\text { sessões/dia). }\end{array}$ & $\begin{array}{c}\text { média de } 300 \\
\text { sessões por mês, } \\
\text { no setor processual, } \\
\text { sendo a média de } \\
\text { audiências } \\
\text { efetivamente } \\
\text { realizadas de } \\
\text { 160/170 por mês. } \\
\text { Isso se dá devido à } \\
\text { não localização dos } \\
\text { réus ou por as } \\
\text { partes comporem- } \\
\text { se no curso do } \\
\text { processo. Quanto } \\
\text { ao pré-processual } \\
\text { são agendadas uma } \\
\text { média de } 70 / 80 \\
\text { audiências/mês. }\end{array}$ & $\begin{array}{c}\text { média de } 3 \\
\text { encontros de } \\
\text { mediação por dia. } \\
\text { No setor pré- } \\
\text { processual, este } \\
\text { volume é menor. }\end{array}$ & & $\begin{array}{c}\text { jurídicos e pequeno } \\
\text { para mediação. Em } \\
81 \text { meses de } \\
\text { atuação, foi } \\
\text { realizado um } \\
\text { mapeamento } \\
\text { estatístico que } \\
\text { revelou que } 83,92 \% \\
\text { (3.513) dos } \\
\text { atendimentos } \\
\text { realizados resultam } \\
\text { em } \\
\text { encaminhamentos } \\
\text { sócio-jurídicos e } \\
\text { atendimentos de pré- } \\
\text { mediação; e } 16,08 \% \\
\text { (673) dos } \\
\text { atendimentos } \\
\text { resultam em } \\
\text { mediação. }\end{array}$ \\
\hline $\begin{array}{c}\text { Há outros } \\
\text { ADRs } \\
\text { oferecidos } \\
\text { pelo } \\
\text { Programa? }\end{array}$ & Não & Não & Não & Não & Não & Não \\
\hline
\end{tabular}

\footnotetext{
${ }^{316} \mathrm{O}$ volume é considerado pequeno quando alcança até 500 sessões de mediação ou conciliação/ano. Entre 500 e 1500 sessões/ano é considerado médio, e acima de 1500 sessões/ano é considerado grande. Estes números foram parâmetros criados para esta pesquisa apenas a título ilustrativo, e se fundam na média de sessões de mediações/conciliações informadas em relação a cada programa.

${ }^{317}$ Os setores têm um controle estatístico, feito a cada mês, sobre o número de audiências, acordos homologados e casos em que a sessão resultou infrutífera sem acordo.

${ }^{318}$ Em 2004, com a unificação dos Tribunais de Alçada (antigos TACs) ao TJSP, o setor de conciliação recebeu aproximadamente 4000 casos, que estavam represados nos antigos TACs.
} 


\section{ii. Triagem dos Conflitos (screening process)}

\begin{tabular}{|c|c|c|c|c|c|c|}
\hline \multirow{2}{*}{$\begin{array}{c}\text { CIDADE } \\
\text { PROGRAMA }\end{array}$} & \multicolumn{4}{|c|}{ SÃO PAULO } & \multirow{2}{*}{$\begin{array}{c}\text { RIO DE JANEIRO } \\
\text { Centro de } \\
\text { Mediação Fórum } \\
\text { Central - setor } \\
\text { processual }\end{array}$} & \multirow{2}{*}{$\begin{array}{c}\text { DISTRITO } \\
\text { FEDERAL } \\
\text { Programa de } \\
\text { Justiça } \\
\text { Comunitária - } \\
\text { TJDF }\end{array}$} \\
\hline & $\begin{array}{l}\text { Fórum Central } \\
\text { João Mendes - } \\
\text { Conciliação } \\
\text { pré-processual, } \\
\text { processual }\end{array}$ & $\begin{array}{c}\text { TJSP - Conciliação } \\
2^{\mathrm{a}} \text { instância }\end{array}$ & $\begin{array}{c}\text { Foro Regional } \\
\text { Pinheiros - } \\
\text { Conciliação pré- } \\
\text { processual e } \\
\text { processual }\end{array}$ & $\begin{array}{c}\text { Foro Regional de } \\
\text { Santana - } \\
\text { Mediação pré- } \\
\text { processual e } \\
\text { processual }\end{array}$ & & \\
\hline $\begin{array}{l}\text { Como o caso é } \\
\text { direcionado à } \\
\text { mediação? }\end{array}$ & $\begin{array}{l}\text { No setor processual é } \\
\text { o juiz que determina } \\
\text { o caso que vai para a } \\
\text { conciliação. } \\
\text { No setor pré- } \\
\text { processual, uma ou } \\
\text { ambas as partes } \\
\text { procuram o setor, já } \\
\text { que não há processo } \\
\text { instaurado. }\end{array}$ & $\begin{array}{c}\text { Os } \\
\text { encaminhamentos } \\
\text { podem ser feitos de } \\
\text { duas formas: } \\
\text { i. Quando a apelação } \\
\text { é distribuída, as } \\
\text { partes já recebem } \\
\text { uma mensagem } \\
\text { sobre a possibilidade } \\
\text { de conciliação } \\
\text { ii. } \text { As partes enviam } \\
\text { email ao setor de } \\
\text { Conciliação, } \\
\text { preenchendo } \\
\text { formulário no qual } \\
\text { requerem a sessãa } \\
\text { de conciliação }{ }^{320} \text {. }\end{array}$ & $\begin{array}{c}\text { Sendo o setor } \\
\text { processual, os } \\
\text { juízes das Varas } \\
\text { Cíveis encaminham } \\
\text { os processos, e isso } \\
\text { pode ser feito tanto } \\
\text { no início da } \\
\text { demanda como na } \\
\text { audiência } \\
\text { preliminar (art. } 331 \\
\text { do CPC). } \\
\text { Sendo o setor pré- } \\
\text { processual, } \\
\text { qualquer pessoa } \\
\text { pode requerer a } \\
\text { conciliação, } \\
\text { cabendo a quem o }\end{array}$ & $\begin{array}{c}\text { Os } \\
\text { encaminhamentos } \\
\text { podem ser feitos de } \\
\text { várias maneiras: i. } \\
\text { os juízes elegem os } \\
\text { casos que vão para o } \\
\text { setor de mediação, e } \\
\text { podem fazê-lo em } \\
\text { audiência, com a } \\
\text { concordância das } \\
\text { partes, ou através de } \\
\text { despacho; ii. setor } \\
\text { técnico faz a triagem } \\
\text { e sugere os casos } \\
\text { aos juízes; iii. há o } \\
\text { pedido de um ou } \\
\text { ambos advogados ao }\end{array}$ & $\begin{array}{c}\text { Os } \\
\text { encaminhamentos } \\
\text { são feitos pelos } \\
\text { Juízes das Varas de } \\
\text { Família, mas a } \\
\text { indicação do caso } \\
\text { para mediação } \\
\text { depende do } \\
\text { consentimento dos } \\
\text { envolvidos, das } \\
\text { partes e advogados. } \\
\text { É possível também } \\
\text { haver a iniciativa de } \\
\text { adesão voluntária } \\
\text { das partes à } \\
\text { mediação, com } \\
\text { requerimento feito }\end{array}$ & $\begin{array}{c}\text { A captação dos } \\
\text { casos é feita pelos } \\
\text { agentes } \\
\text { comunitários, em } \\
\text { seu dia-a-dia e } \\
\text { ambiente de } \\
\text { convívio } \\
\text { comunitário (igrejas, } \\
\text { eventos, conversas } \\
\text { no bairro). O } \\
\text { solicitante procura o } \\
\text { programa por meio } \\
\text { do agente } \\
\text { comunitário } \\
\text { correspondente à sua } \\
\text { área de moradia ou } \\
\text { do Núcleo }\end{array}$ \\
\hline
\end{tabular}

\footnotetext{
${ }^{319}$ Havendo interesse, uma delas ou ambas podem peticionar ao relator nos autos pedindo a conciliação.

${ }^{320}$ Atualmente, $90 \%$ dos pedidos de conciliação são feitos desta segunda forma. O email chega ao Setor, que entra em contato com o advogado da parte contrária para consultar sobre sua anuência e agendar a sessão. Havendo a concordância de ambas as partes, é agendado o dia da sessão e o processo é requisitado ao setor onde ele está localizado. O setor de conciliação recebe uma média de 50 emails com pedidos por dia, mas há uma quebra em quase $50 \%$ deste número, nos casos em que o advogado da
} 


\begin{tabular}{|c|c|c|c|c|c|c|}
\hline & & & $\begin{array}{l}\text { atende orientar } \\
\text { sobre as vantagens } \\
\text { e desvantagens da } \\
\text { conciliação. }\end{array}$ & $\begin{array}{l}\text { juiz, através de } \\
\text { requerimento de } \\
\text { mediação; iv. } \\
\text { funcionários } \\
\text { indicam o setor de } \\
\text { mediação para } \\
\text { terceiros, por já } \\
\text { conhecerem o } \\
\text { trabalho. }\end{array}$ & ao juiz ${ }^{321}$. & Comunitário. \\
\hline $\begin{array}{c}\text { Critérios ou } \\
\text { requisitos para } \\
\text { a filtragem dos } \\
\text { conflitos }\end{array}$ & $\begin{array}{l}\text { No setor processual, } \\
\text { cada juiz aplica os } \\
\text { seus critérios. No } \\
\text { setor pré-processual, } \\
\text { apenas podem ser } \\
\text { mediados casos cuja } \\
\text { competência } \\
\text { territorial seja do } \\
\text { Fórum João Mendes } \\
\text { Júnior, salvo se não } \\
\text { houver setor de } \\
\text { conciliação no } \\
\text { Fórum de } \\
\text { competência. }\end{array}$ & $\begin{array}{l}\text { Quem faz esta } \\
\text { triagem é o próprio } \\
\text { advogado, junto às } \\
\text { partes, ao requisitar } \\
\text { a sessão de } \\
\text { conciliação } \\
\text { c22. }\end{array}$ & $\begin{array}{c}\text { No setor } \\
\text { processual, cada } \\
\text { juiz aplica os seus } \\
\text { critérios. No setor } \\
\text { pré-processual, } \\
\text { apenas podem ser } \\
\text { mediados casos } \\
\text { cuja competência } \\
\text { territorial seja do } \\
\text { Fórum Regional de } \\
\text { Pinheiros. }\end{array}$ & $\begin{array}{l}\text { O critério é que a } \\
\text { relação seja, } \\
\text { preferencialmente, } \\
\text { continuada. }\end{array}$ & $\begin{array}{c}\text { É o juiz quem } \\
\text { estabelece e aplica } \\
\text { os critérios. }\end{array}$ & $\begin{array}{l}\text { Na fase de triagem, } \\
\text { o agente } \\
\text { comunitário marca o } \\
\text { atendimento com o } \\
\text { solicitante, ouve a } \\
\text { história e preenche } \\
\text { o registro de } \\
\text { encaminhamento, } \\
\text { quando se trata de } \\
\text { informação, ou o } \\
\text { formulário de } \\
\text { atendimento, quando } \\
\text { se trata de } \\
\text { mediação } 0^{323} \text {. }\end{array}$ \\
\hline
\end{tabular}

parte contrária não concorda em se submeter à conciliação. Há casos em que o Relator encaminha por iniciativa própria o caso ao setor, por vislumbrar a possibilidade da composição, mas, ainda assim, as partes são consultadas quanto ao seu interesse.

${ }^{321}$ De acordo com a Resolução 19/2009, não podem ser objeto de mediação os conflitos em que um dos participantes não demonstre interesse no procedimento, careça de capacidade intelecto volitiva necessária à negociação, verse sobre fato tipificado em lei como crime de ação penal pública incondicionada. Em casos de desequilíbrio de poder, a mediação também pode não ser realizada.

${ }^{322} \mathrm{Na}$ fase experimental, essa triagem era feita pelo setor de conciliação, nos casos em que a sentença fosse parcialmente procedente e houvesse espaço para conciliação. Entretanto, depois se percebeu que mesmo as partes que ganharam em $1^{a}$ instancia também poderiam ter interesse na conciliação, ou em face da demora do julgamento em apelação (média de 3 anos) ou em face da possibilidade de reforma da decisão.

${ }^{323}$ Após o primeiro atendimento de mediação, o agente leva o caso ao Centro Comunitário para discussão em conjunto com a tríade multidisciplinar e demais agentes comunitários que queiram participar. A pré-mediação é sempre com as partes em separado, e depois é realizada a mediação, podendo haver o encaminhamento para a rede de atendimento (saúde, educação, Procon, Defensoria, dentre outros) 


\begin{tabular}{|c|c|c|c|c|c|c|}
\hline $\begin{array}{l}\text { Há formulário } \\
\text { de requisição? }\end{array}$ & $\begin{array}{l}\text { Não. No setor pré- } \\
\text { processual, as partes } \\
\text { procuram o setor de } \\
\text { conciliação e no } \\
\text { atendimento } \\
\text { apresentam os fatos e } \\
\text { sua pretensão. É } \\
\text { elaborada uma carta } \\
\text { convite e um termo } \\
\text { de ajuizamento e, no } \\
\text { atendimento, já há a } \\
\text { intimação da parte } \\
\text { reclamante acerca da } \\
\text { data da audiência. }\end{array}$ & $\begin{array}{c}\text { Sim, existe um } \\
\text { formulário } \\
\text { disponível às partes, } \\
\text { no site do Tribunal } \\
\text { para requererem a } \\
\text { conciliação. Mas } \\
\text { elas podem também } \\
\text { peticionar nos autos. }\end{array}$ & $\begin{array}{l}\text { No setor } \\
\text { processual, não. No } \\
\text { pré-processual, é } \\
\text { entregue no } \\
\text { atendimento um } \\
\text { esboço de } \\
\text { orientações de } \\
\text { como funciona o } \\
\text { setor de } \\
\text { conciliação. A } \\
\text { parte lê e, havendo } \\
\text { concordância, } \\
\text { preenche uma ficha } \\
\text { com seus dados e } \\
\text { dados da parte } \\
\text { reclamada. }\end{array}$ & $\begin{array}{l}\text { Não, mas há uma } \\
\text { série de formulários } \\
\text { utilizados durante o } \\
\text { processo de } \\
\text { mediação. }\end{array}$ & $\begin{array}{c}\text { Sim, é preenchido } \\
\text { um formulário que } \\
\text { identifica o número } \\
\text { do processo, a ação, } \\
\text { as partes, nome e } \\
\text { idade dos filhos (no } \\
\text { caso de guarda), a } \\
\text { forma de } \\
\text { encaminhamento } \\
\text { (em audiência, por } \\
\text { despacho do juiz ou } \\
\text { requerimento das } \\
\text { partes), os processos } \\
\text { relacionados, e as } \\
\text { datas em que são } \\
\text { agendadas as } \\
\text { sessões de } \\
\text { mediação, bem } \\
\text { como a designação } \\
\text { da equipe de } \\
\text { mediadores que } \\
\text { atuará no caso. } \\
\end{array}$ & $\begin{array}{l}\text { Sim, há formulários } \\
\text { de encaminhamento } \\
\text { e atendimento. }\end{array}$ \\
\hline $\begin{array}{l}\text { Quando o caso } \\
\text { pode ser } \\
\text { remetido à } \\
\text { mediação? }\end{array}$ & $\begin{array}{l}\text { No setor processual, } \\
\text { a qualquer tempo, } \\
\text { preferencialmente no } \\
\text { início da demanda. } \\
\text { Há inclusive um } \\
\text { modelo de despacho, } \\
\text { sugerido pelo setor } \\
\text { de conciliação aos } \\
\text { juízes, para citar e já } \\
\text { chamar as partes } \\
\text { para conciliação, } \\
\text { suspendendo o prazo }\end{array}$ & $\begin{array}{c}\text { Preferencialmente } \\
\text { no início, logo após } \\
\text { a distribuição, mas } \\
\text { em tese pode ocorrer } \\
\text { a qualquer tempo, } \\
\text { inclusive mais de } \\
\text { um pedido de } \\
\text { conciliação, em } \\
\text { diferentes } \\
\text { momentos. }\end{array}$ & $\begin{array}{l}\text { A qualquer tempo: } \\
\text { no início da } \\
\text { demanda (mais } \\
\text { comum no rito } \\
\text { sumário), na } \\
\text { audiência } \\
\text { preliminar (rito } \\
\text { ordinário) ou } \\
\text { depois, a critério do } \\
\text { juiz. }\end{array}$ & $\begin{array}{l}\text { Em qualquer fase do } \\
\text { procedimento. } \\
\text { Normalmente, os } \\
\text { juízes encaminham } \\
\text { após a contestação. }\end{array}$ & $\begin{array}{c}\text { Preferencialmente } \\
\text { no início do } \\
\text { processo. } \\
\text { De acordo com a } \\
\text { Resolução } \mathrm{n}^{\circ} \\
\text { 19/2009, a mediação } \\
\text { poderá ser solicitada } \\
\text { pelas partes a } \\
\text { qualquer tempo, } \\
\text { ainda que na } \\
\text { pendência de } \\
\text { recurso, ou indicada }\end{array}$ & A qualquer tempo. \\
\hline
\end{tabular}




\begin{tabular}{|c|c|c|c|c|c|c|}
\hline & $\begin{array}{c}\text { para que o réu } \\
\text { conteste. }\end{array}$ & & & & pelo juiz relator. & \\
\hline $\begin{array}{l}\text { Há mediação } \\
\text { sem ação } \\
\text { judicial (pre } \\
\text { suit } \\
\text { mediation)? }\end{array}$ & $\begin{array}{l}\text { Sim, esse é o caso do } \\
\text { setor pré-processual }\end{array}$ & Não & $\begin{array}{c}\text { Sim, esse é o caso } \\
\text { do setor pré- } \\
\text { processual }\end{array}$ & $\begin{array}{l}\text { Sim, esse é o caso } \\
\text { do setor pré- } \\
\text { processual }\end{array}$ & $\begin{array}{c}\text { Sim, de acordo com } \\
\text { a resolução 19/2009, } \\
\text { é possível haver } \\
\text { mediação antes da } \\
\text { distribuição da ação. }\end{array}$ & Sim \\
\hline $\begin{array}{l}\text { Pode haver o } \\
\text { direcionamento } \\
\text { do conflito } \\
\text { para mediações } \\
\text { privadas? }\end{array}$ & Não & $\begin{array}{l}\text { Não há regra sobre } \\
\text { isso, mas as partes } \\
\text { poderão, em } \\
\text { conjunto, pedir a } \\
\text { suspensão do } \\
\text { processo, o que } \\
\text { ficará a critério do } \\
\text { Relator deferir. }\end{array}$ & $\begin{array}{l}\text { Não há regra sobre } \\
\text { isso. A resposta } \\
\text { depende do caso } \\
\text { concreto. }\end{array}$ & $\begin{array}{l}\text { Não há regra sobre } \\
\text { isso. A rede que se } \\
\text { pode oferecer às } \\
\text { partes diz respeito a } \\
\text { psicólogos e } \\
\text { assistentes sociais, } \\
\text { quando solicitado } \\
\text { pelo mediando. }\end{array}$ & ND & $\begin{array}{c}\text { Não. Como a } \\
\text { maioria das pessoas } \\
\text { atendidas é de baixa } \\
\text { renda, os } \\
\text { encaminhamentos } \\
\text { geralmente são } \\
\text { feitos à Defensoria } \\
\text { Pública. }\end{array}$ \\
\hline
\end{tabular}

\section{iii. Características do Procedimento}

\begin{tabular}{|c|c|c|c|c|c|c|}
\hline CIDADE & \multicolumn{4}{|c|}{ SÃO PAULO } & \multirow{2}{*}{$\begin{array}{c}\text { RIO DE JANEIRO } \\
\text { Centro de } \\
\text { Mediação Fórum } \\
\text { Central - setor } \\
\text { processual }\end{array}$} & \multirow{2}{*}{$\begin{array}{c}\text { DISTRITO } \\
\text { FEDERAL } \\
\begin{array}{c}\text { Programa de } \\
\text { Justiça } \\
\text { Comunitária - } \\
\text { TJDF }\end{array}\end{array}$} \\
\hline FÓRUM & $\begin{array}{l}\text { Fórum Central } \\
\text { João Mendes - } \\
\text { Conciliação } \\
\text { pré-processual, } \\
\text { processual }\end{array}$ & $\begin{array}{c}\text { TJSP - } \\
\text { Conciliação } 2^{\mathrm{a}} \\
\text { instância }\end{array}$ & $\begin{array}{c}\text { Foro Regional } \\
\text { Pinheiros - } \\
\text { Conciliação pré- } \\
\text { processual e } \\
\text { processual }\end{array}$ & $\begin{array}{c}\text { Foro Regional de } \\
\text { Santana - } \\
\text { Mediação pré- } \\
\text { processual e } \\
\text { processual }\end{array}$ & & \\
\hline $\begin{array}{c}\text { A mediação } \\
\text { suspende a ação } \\
\text { judicial em curso? }\end{array}$ & $\begin{array}{c}\text { No setor } \\
\text { processual, os } \\
\text { prazos processuais } \\
\text { são suspensos, }\end{array}$ & $\begin{array}{c}\text { Os prazos são } \\
\text { suspensos, e, não } \\
\text { havendo acordo, o } \\
\text { processo retoma o }\end{array}$ & $\begin{array}{l}\text { Na maioria das } \\
\text { vezes, as partes } \\
\text { aguardam a } \\
\text { realização da }\end{array}$ & $\begin{array}{l}\text { Em geral, o processo } \\
\text { fica suspenso, } \\
\text { enquanto perdurar a } \\
\text { mediação, e os }\end{array}$ & $\begin{array}{l}\text { Sim, o processo } \\
\text { pode ser suspenso } \\
\text { por até } 45 \text { dias } \\
\text { (prorrogáveis a }\end{array}$ & $\begin{array}{c}\text { Não há processo } \\
\text { judicial. }\end{array}$ \\
\hline
\end{tabular}




\begin{tabular}{|c|c|c|c|c|c|c|}
\hline & $\begin{array}{c}\text { voltando a ser } \\
\text { contados a partir da } \\
\text { audiência de } \\
\text { tentativa de } \\
\text { conciliação, caso } \\
\text { não haja o acordo. }\end{array}$ & $\begin{array}{l}\text { mesmo momento } \\
\text { em que estava. }\end{array}$ & $\begin{array}{l}\text { audiência, porém, } \\
\text { nada impede de } \\
\text { peticionarem aos } \\
\text { juízes pedindo } \\
\text { suspensão de prazo. }\end{array}$ & $\begin{array}{c}\text { mediandos são } \\
\text { informados disso e } \\
\text { aceitam. }\end{array}$ & $\begin{array}{l}\text { critério do juiz ou do } \\
\text { relator), a pedido do } \\
\text { advogado, conforme } \\
\text { a resolução 19/2009. }\end{array}$ & \\
\hline $\begin{array}{l}\text { Qual é a pauta, a } \\
\text { duração e a média } \\
\text { do número de } \\
\text { sessões no setor? }\end{array}$ & $\begin{array}{l}\text { Nos setores pré- } \\
\text { processual e } \\
\text { processual, a pauta } \\
\text { é de } \\
\text { aproximadamente } \\
30 \text { dias }^{324} \text {. } \\
\text { No pré-processual, } \\
\text { ocorre uma média } \\
\text { de } 400 \\
\text { audiências/mês } \\
\text { no } \\
\text { processual, uma } \\
\text { média de } 1000 \\
\text { audiências/mês. Em } \\
\text { ambos a duração } \\
\text { varia de acordo } \\
\text { com cada caso } \\
\text { com }\end{array}$ & $\begin{array}{l}\text { Por dia podem ser } \\
\text { agendadas } 24 \\
\text { sessões de } \\
\text { conciliação, metade } \\
\text { de manhã e metade } \\
\text { à tarde, com três } \\
\text { mediadores em cada } \\
\text { turno. As sessões } \\
\text { duram em média } 45 \\
\text { minutos, com } \\
\text { destaque para o fato } \\
\text { de que na antessala } \\
\text { de espera os } \\
\text { advogados já podem } \\
\text { entrar em contato e } \\
\text { começar as } \\
\text { negociações. }\end{array}$ & $\begin{array}{l}\text { O tempo médio da } \\
\text { pauta é de } 30 \text { dias, e } \\
\text { o tempo de duração } \\
\text { da sessão pode } \\
\text { variar de acordo } \\
\text { com o caso (uma } \\
\text { média de } 20 \\
\text { minutos, intervalo } \\
\text { em que são } \\
\text { marcadas as sessões } \\
\text { no mesmo dia). }\end{array}$ & $\begin{array}{c}\text { O tempo médio da } \\
\text { pauta é de } 2 \text { a } 3 \\
\text { semanas. Cada } \\
\text { sessão tem uma } \\
\text { média de duração de } \\
1 \text { hora e } 15 \text { minutos, } \\
\text { e o número de } \\
\text { encontros depende } \\
\text { do caso. }\end{array}$ & $\begin{array}{c}\text { As sessões tem } \\
\text { normalmente duas } \\
\text { horas de duração e } \\
\text { um caso, em média, } \\
\text { precisa de } 3 \text { a } 4 \\
\text { sessões para que se } \\
\text { alcance uma solução } \\
\text { (intervalos são } \\
\text { normalmente } \\
\text { quinzenais). } \\
\text { O centro de } \\
\text { mediação do Fórum } \\
\text { Central atua em } 3 \\
\text { turnos. Logo no } \\
\text { primeiro } \\
\text { atendimento, são } \\
\text { agendadas todas as } \\
\text { sessões de mediação } \\
\text { do caso. }\end{array}$ & $\begin{array}{c}\text { Depende do caso, } \\
\text { mas o tempo de } \\
\text { espera para um } \\
\text { atendimento no } \\
\text { programa de } \\
\text { justiça } \\
\text { comunitária é } \\
\text { normalmente } \\
\text { menor do que o } \\
\text { tempo de espera } \\
\text { no JEC e para } \\
\text { atendimento na } \\
\text { Defensoria } \\
\text { Pública. }\end{array}$ \\
\hline $\begin{array}{l}\text { É possível realizar } \\
\text { a mediacão por }\end{array}$ & $\begin{array}{l}\text { Não. No setor pré- } \\
\text { processual, é }\end{array}$ & $\begin{array}{c}\text { Não. O } \\
\text { agendamento é feito }\end{array}$ & $\begin{array}{l}\text { Não. A notificação } \\
\text { das partes é feita }\end{array}$ & $\begin{array}{l}\text { Não. No setor pré- } \\
\text { processual a }\end{array}$ & $\begin{array}{c}\text { A mediação pode ser } \\
\text { designada em }\end{array}$ & $\begin{array}{l}\text { Não é possível } \\
\text { mediacão por }\end{array}$ \\
\hline
\end{tabular}

${ }^{324}$ De acordo com o Provimento 953/2005, a pauta de audiências do Setor de Conciliação é independente em relação à pauta do juízo e as audiências de conciliação são designadas em prazo não superior a 30 dias da reclamação ou do recebimento dos autos no Setor.

${ }^{325} \mathrm{O}$ entrevistado ressalta que a pauta do JEC é bem superior, em torno de 6 meses, o que faz com que o setor de conciliação pré-processual atenda muito ao público do Juizado Especial, assim como do PROCON.

${ }^{326} \mathrm{Na}$ primeira quinzena há normalmente mais audiências designadas do que na $2^{\text {a }}$ quinzena do mês. O Setor de Conciliação se organizou para oferecer 40 horários por mês para cada Vara (20 para cada juiz - titular e auxiliar), mas há sobras e redistribuições. Há juízes que utilizam muito o setor, e alguns poucos juízes - 6 a 7 - que nunca o utilizaram. 


\begin{tabular}{|c|c|c|c|c|c|c|}
\hline $\begin{array}{l}\text { telefone ou email? } \\
\text { Como as partes } \\
\text { são notificadas? }\end{array}$ & $\begin{array}{l}\text { elaborado um termo } \\
\text { de ajuizamento com } \\
\text { a pretensão da parte } \\
\text { e carta convite à } \\
\text { outra parte. No } \\
\text { setor processual, as } \\
\text { partes são } \\
\text { intimadas pela } \\
\text { imprensa oficial, } \\
\text { através de seus } \\
\text { advogados. }\end{array}$ & $\begin{array}{l}\text { em } 10 \text { dias, mas o } \\
\text { que leva mais tempo } \\
\text { é o contato com os } \\
\text { advogados para } \\
\text { checar sua anuência } \\
\text { e disponibilidade } \\
\text { para a sessão de } \\
\text { conciliação. }\end{array}$ & $\begin{array}{c}\text { pelo próprio } \\
\text { Cartório da Vara } \\
\text { que remeteu o caso } \\
\text { ao setor de } \\
\text { conciliação. Nos } \\
\text { casos pré- } \\
\text { processuais a } \\
\text { expedição da carta } \\
\text { convite é feita pelos } \\
\text { funcionários do } \\
\text { setor. }\end{array}$ & $\begin{array}{c}\text { notificação pode ser } \\
\text { feita pela parte ou } \\
\text { pelo funcionário do } \\
\text { Setor, através de } \\
\text { contato telefônico. } \\
\text { No setor processual, } \\
\text { a intimação é feita } \\
\text { na audiência ou por } \\
\text { despacho, sendo } \\
\text { pessoal ou através } \\
\text { dos advogados. }\end{array}$ & $\begin{array}{l}\text { audiência (ficando } \\
\text { as partes cientes } \\
\text { neste momento), por } \\
\text { despacho do juiz } \\
\text { (publicado) ou por } \\
\text { iniciativa das partes. } \\
\text { Dependendo do } \\
\text { caso, o cartório ou o } \\
\text { centro de mediação } \\
\text { informa a data da } 1^{\text {a }} \\
\text { sessão por telefone } \\
\text { ou AR, sendo a data } \\
\text { publicada no DO. }\end{array}$ & telefone ou email. \\
\hline $\begin{array}{l}\text { Há prazos para a } \\
\text { mediação? } \\
\text { Durante a sessão, } \\
\text { há normalmente } \\
\text { sessões individuais } \\
\text { com as partes } \\
\text { (caucus)? }\end{array}$ & Não & Não & $\begin{array}{l}\text { Não. No cível não } \\
\text { ocorre caucus. } \\
\text { Na área de família, } \\
\text { pode ou não } \\
\text { ocorrer, } \\
\text { dependendo do } \\
\text { consentimento das } \\
\text { partes e do } \\
\text { conciliador. }\end{array}$ & $\begin{array}{c}\text { Não há prazos. } \\
\text { Durante os } \\
\text { encontros pode } \\
\text { haver caucus, } \\
\text { dependendo do caso. }\end{array}$ & $\begin{array}{l}\text { Não há prazos, e } \\
\text { pode haver caucus. }\end{array}$ & $\begin{array}{l}\text { Não há prazos. Há } \\
\text { caucus na pré- } \\
\text { mediação. } \\
\text { Durante a sessão } \\
\text { de mediação, se } \\
\text { for necessário } \\
\text { também poderá } \\
\text { haver sessão } \\
\text { individual. }\end{array}$ \\
\hline $\begin{array}{l}\text { Confidencialidade } \\
\text { da mediação }\end{array}$ & $\begin{array}{c}\text { Sim. De acordo } \\
\text { com o art. } 13 \text { do } \\
\text { Provimento } \\
\text { 953/2005, o } \\
\text { conciliador, as } \\
\text { partes, seus } \\
\text { advogados e demais } \\
\text { envolvidos nas } \\
\text { atividades, ficam } \\
\text { submetidos à } \\
\text { cláusula de }\end{array}$ & $\begin{array}{c}\text { Sim. De acordo com } \\
\text { o art. } 5^{\circ} \text { do Prov. } \\
843 / 2004, \text { o } \\
\text { conciliador, as } \\
\text { partes e seus } \\
\text { advogados ficam } \\
\text { submetidos à } \\
\text { cláusula de } \\
\text { confidencialidade, } \\
\text { devendo guardar } \\
\text { sigilo a respeito do }\end{array}$ & $\begin{array}{c}\text { Sim. De acordo } \\
\text { com o art. } 13 \text { do } \\
\text { Provimento } \\
\text { 953/2005. Não } \\
\text { existe envolvimento } \\
\text { do juiz nas sessões } \\
\text { de conciliação, que } \\
\text { são confidenciais, } \\
\text { motivo pelo qual } \\
\text { nada do que se fala } \\
\text { na sessão é }\end{array}$ & $\begin{array}{l}\text { Sim. A mediação é } \\
\text { totalmente } \\
\text { confidencial. A } \\
\text { exceção é no caso de } \\
\text { violência contra } \\
\text { menor. Todos } \\
\text { assinam o termo de } \\
\text { confidencialidade. } \\
\text { Os registros são só } \\
\text { dos mediadores. Não } \\
\text { há qualquer } \\
\end{array}$ & $\begin{array}{c}\text { O procedimento é } \\
\text { confidencial, sob } \\
\text { pena de prática do } \\
\text { crime do art. } 154 \text { do } \\
\text { CP. } \\
\text { Todas as } \\
\text { informações } \\
\text { provenientes de } \\
\text { arquivos, relatos do } \\
\text { caso, notas do } \\
\text { mediador ou outro }\end{array}$ & ND \\
\hline
\end{tabular}




\begin{tabular}{|c|c|c|c|c|c|c|}
\hline & $\begin{array}{l}\text { confidencialidade, } \\
\text { devendo guardar } \\
\text { sigilo a respeito do } \\
\text { que for dito, } \\
\text { exibido ou debatido } \\
\text { na sessão, não } \\
\text { sendo tais } \\
\text { ocorrências } \\
\text { consideradas para } \\
\text { outros fins que não } \\
\text { os da tentativa de } \\
\text { conciliação. }\end{array}$ & $\begin{array}{l}\text { que for dito, exibido } \\
\text { ou debatido na } \\
\text { sessão. Tais } \\
\text { ocorrências não } \\
\text { serão consideradas } \\
\text { como prova para } \\
\text { outros fins, que não } \\
\text { os da conciliação. }\end{array}$ & reduzido a termo. & $\begin{array}{l}\text { envolvimento dos } \\
\text { juízes nos trabalhos. }\end{array}$ & $\begin{array}{c}\text { material não } \\
\text { poderão ser } \\
\text { utilizadas pelos } \\
\text { participantes da } \\
\text { mediação nem } \\
\text { admitidas como } \\
\text { prova em juízo ou } \\
\text { fora dele }^{327} \text {. }\end{array}$ & \\
\hline $\begin{array}{c}\text { É possível } \\
\text { requerer } \\
\text { aprovação, revisão } \\
\text { ou homologação } \\
\text { do acordo pela } \\
\text { Corte? }\end{array}$ & $\begin{array}{l}\text { Os acordos obtidos } \\
\text { são sempre } \\
\text { homologados pelo } \\
\text { Juiz coordenador. } \\
\text { Há um modelo } \\
\text { adotado pelos } \\
\text { funcionários do } \\
\text { Setor, que auxiliam } \\
\text { os conciliadores } \\
\text { durante a sessão. }\end{array}$ & $\begin{array}{l}\text { Os acordos obtidos } \\
\text { são homologados } \\
\text { pelo Presidente da } \\
\text { Sessão de Direito } \\
\text { Privado. As partes } \\
\text { podem também } \\
\text { fazer acordo parcial, } \\
\text { e manter a demanda } \\
\text { judicial sobre a } \\
\text { parte que não foi } \\
\text { objeto de } \\
\text { conciliação. }\end{array}$ & $\begin{array}{l}\text { Os acordos obtidos } \\
\text { são reduzidos a } \\
\text { termo e } \\
\text { homologados pelo } \\
\text { juiz da Vara (e não } \\
\text { pelo juiz } \\
\text { coordenador do } \\
\text { setor). }\end{array}$ & $\begin{array}{l}\text { Não há a redação de } \\
\text { acordos no setor. } \\
\text { Havendo consenso } \\
\text { na mediação, são os } \\
\text { advogados que } \\
\text { redigem o acordo } \\
\text { fora da sessão, e } \\
\text { podem pedir a } \\
\text { homologação } \\
\text { judicial e a extinção } \\
\text { do processo, no caso } \\
\text { de mediação } \\
\text { incidental. }\end{array}$ & $\begin{array}{l}\text { Havendo acordo } \\
\text { (parcial ou total), o } \\
\text { mediador elaborará } \\
\text { o respectivo termo e } \\
\text { o submeterá às } \\
\text { partes. Depois, os } \\
\text { advogados das } \\
\text { partes, se não } \\
\text { estiverem presentes } \\
\text { na sessão, tomarão } \\
\text { ciência do que foi } \\
\text { acordado. Aprovado } \\
\text { o acordo, ele será } \\
\text { remetido ao juiz ou } \\
\text { relator do processo } \\
\text { para a homologação } \\
\text { judicial. }\end{array}$ & $\begin{array}{l}\text { Quando há acordo, } \\
\text { o caso pode ser } \\
\text { encaminhado à } \\
\text { Defensoria na } \\
\text { hipótese de } \\
\text { necessidade de } \\
\text { pedido de } \\
\text { homologação } \\
\text { judicial. } \\
\text { Recentemente foi } \\
\text { firmado convênio } \\
\text { com os Núcleos de } \\
\text { Prática Jurídica de } \\
\text { algumas } \\
\text { faculdades para } \\
\text { estes pedidos de } \\
\text { homologação } \\
\text { judicial. }\end{array}$ \\
\hline É possível & Não é possível & Não é possível & Não é possível & Não há recurso, e as & ND & As partes podem \\
\hline
\end{tabular}

\footnotetext{
${ }^{327}$ Há exceções à confidencialidade, como no caso de cometimento de crime, casos de má prática da atividade profissional, abuso ou negligência de menor, dentre outros previstos na Resolução 19/2009.
} 


\begin{tabular}{|c|c|c|c|c|c|}
\hline $\begin{array}{c}\text { recorrer do } \\
\text { acordo? E } \\
\text { submetê-lo à nova } \\
\text { mediação? }\end{array}$ & $\begin{array}{l}\text { recorrer do acordo. } \\
\text { Quanto à nova } \\
\text { mediação, } \\
\text { dependeria do que } \\
\text { aconteceu na } \\
\text { anterior. Caso tenha } \\
\text { sido infrutífera, } \\
\text { não; caso tenha } \\
\text { sido prejudicada } \\
\text { por ausência de } \\
\text { uma das partes, } \\
\text { pode haver outra } \\
\text { audiência mas a } \\
\text { redesignação } \\
\text { depende da } \\
\text { avaliação do Juiz. }\end{array}$ & $\begin{array}{l}\text { recorrer do acordo. } \\
\text { Mas as partes } \\
\text { podem requerer a } \\
\text { redesignação da } \\
\text { conciliação, no } \\
\text { prazo máximo de } 60 \\
\text { dias. }\end{array}$ & $\begin{array}{l}\text { recorrer do acordo. } \\
\text { No setor processual, } \\
\text { se não houver } \\
\text { acordo, as partes } \\
\text { podem, no decorrer } \\
\text { do processo, pedir } \\
\text { ao juiz a designação } \\
\text { de nova sessão. }\end{array}$ & $\begin{array}{c}\text { partes podem se } \\
\text { submeter a mais de } \\
\text { uma mediação. } \\
\text { Muitas vezes um ou } \\
\text { ambos os mediandos } \\
\text { não estão prontos, } \\
\text { na primeira vez, } \\
\text { para a mediação. } \\
\text { Posteriormente, eles } \\
\text { pedem novo } \\
\text { encontro. }\end{array}$ & $\begin{array}{l}\text { submeter o mesmo } \\
\text { caso à nova } \\
\text { mediação }\end{array}$ \\
\hline
\end{tabular}

\section{iv. Papel dos Advogados}

\begin{tabular}{|c|c|c|c|c|c|c|}
\hline CIDADE & \multicolumn{2}{|c|}{ SÃO PAULO } & RIO DE JANEIRO & $\begin{array}{c}\text { DISTRITO } \\
\text { FEDERAL }\end{array}$ \\
\hline FÓRUM & $\begin{array}{c}\text { Fórum Central } \\
\text { João Mendes - } \\
\text { Conciliação } \\
\text { pré-processual, } \\
\text { processual }\end{array}$ & $\begin{array}{c}\text { TJSP - Conciliação } \\
\mathbf{2}^{\mathrm{a}} \text { instância } \\
\text { Pinheiros - } \\
\text { Conciliação pré- } \\
\text { processual e } \\
\text { processual }\end{array}$ & $\begin{array}{c}\text { Foro Regional de } \\
\text { Santana - } \\
\text { Mediação pré- } \\
\text { processual e } \\
\text { processual }\end{array}$ & $\begin{array}{c}\text { Centro de } \\
\text { Mediação Fórum } \\
\text { Central - setor } \\
\text { processual }\end{array}$ & $\begin{array}{c}\text { Programa de } \\
\text { Justiça } \\
\text { Comunitária - } \\
\text { TJDF }\end{array}$ \\
\hline $\begin{array}{c}\text { As partes } \\
\text { precisam estar } \\
\text { assistidas por }\end{array}$ & $\begin{array}{c}\text { Sim, no setor } \\
\text { processual. Não, no } \\
\text { setor pré-processual. }\end{array}$ & $\begin{array}{c}\text { Sim. } \\
\text { comparecer sem }\end{array}$ & $\begin{array}{c}\text { Sim, no setor } \\
\text { processual. Não, no } \\
\text { setor pré- }\end{array}$ & $\begin{array}{c}\text { Não. Mas é } \\
\text { recomendável que } \\
\text { os advogados de }\end{array}$ & $\begin{array}{c}\text { Não. É facultativa a } \\
\text { presença dos } \\
\text { advogados, mas isso }\end{array}$ & $\begin{array}{c}\text { Não. No Programa } \\
\text { de Justiça } \\
\text { Comunitária, até a }\end{array}$ \\
\hline
\end{tabular}




\begin{tabular}{|c|c|c|c|c|c|c|}
\hline advogado? & & $\begin{array}{l}\text { advogado, a sessão } \\
\text { será adiada. }\end{array}$ & processual. & $\begin{array}{l}\text { ambas as partes } \\
\text { estejam na pré- } \\
\text { mediação, para a } \\
\text { apresentação dos } \\
\text { trabalhos. }\end{array}$ & $\begin{array}{c}\text { depende do } \\
\text { consentimento das } \\
\text { partes. } \\
\text { Apenas caso seja } \\
\text { obtido o acordo, os } \\
\text { advogados são } \\
\text { consultados e o } \\
\text { assinam juntamente } \\
\text { com as partes. }\end{array}$ & $\begin{array}{c}\text { presente data, não } \\
\text { houve mediações } \\
\text { com a presença de } \\
\text { advogados }\end{array}$ \\
\hline $\begin{array}{l}\text { Os advogados } \\
\text { precisam estar } \\
\text { presentes na } \\
\text { sessão de } \\
\text { mediação? }\end{array}$ & $\begin{array}{l}\text { Sim, apenas no setor } \\
\text { processual. Com o } \\
\text { acordo há a extinção } \\
\text { do processo e, } \\
\text { segundo o } \\
\text { entrevistado, pelo } \\
\text { código de ética, os } \\
\text { advogados precisam } \\
\text { estar presentes } \\
\text { representando as } \\
\text { partes. }\end{array}$ & $\begin{array}{c}\text { Sim, mas é } \\
\text { recomendável que as } \\
\text { partes também } \\
\text { estejam presentes, } \\
\text { pois a elas é } \\
\text { direcionada a } \\
\text { conciliação. }\end{array}$ & $\begin{array}{l}\text { Sim, apenas no } \\
\text { setor processual. }\end{array}$ & $\begin{array}{l}\text { Os advogados não } \\
\text { precisam estar } \\
\text { presentes. } \\
\text { Recomenda-se sua } \\
\text { presença apenas na } \\
\text { pré-mediação, } \\
\text { inclusive para } \\
\text { informá-los que o } \\
\text { mediador não } \\
\text { fornece qualquer } \\
\text { informação jurídica } \\
\text { aos mediandos, nem } \\
\text { há a redação de } \\
\text { eventual acordo. } \\
\text { Essas tarefas são do } \\
\text { advogado. }\end{array}$ & $\begin{array}{c}\text { Não. Mas determina } \\
\text { a Resolução } 19 / 2009 \\
\text { que se apenas uma } \\
\text { das partes } \\
\text { comparecer assistida } \\
\text { por advogado, a } \\
\text { outra, se quiser, } \\
\text { poderá ter } \\
\text { assistência judiciária } \\
\text { prestada pela } \\
\text { Defensoria Pública. }\end{array}$ & Não \\
\hline $\begin{array}{l}\text { Os advogados } \\
\text { podem estar } \\
\text { presentes na } \\
\text { sessão sem as } \\
\text { partes? }\end{array}$ & $\begin{array}{l}\text { Sim, muito embora } \\
\text { no setor pré- } \\
\text { processual, na } \\
\text { maioria das vezes, as } \\
\text { partes compareçam } \\
\text { sem advogados, já } \\
\text { que o processo ainda } \\
\text { não foi instaurado. }\end{array}$ & Sim & $\begin{array}{l}\text { Sim, mas não é } \\
\text { recomendável, pois } \\
\text { o setor de } \\
\text { conciliação visa a } \\
\text { construção do } \\
\text { acordo pelas partes. }\end{array}$ & Não & $\begin{array}{l}\text { Não. Ambas as } \\
\text { partes precisam estar } \\
\text { presentes. }\end{array}$ & Não \\
\hline
\end{tabular}




\section{v. Papel das Partes}

\begin{tabular}{|c|c|c|c|c|c|c|}
\hline CIDADE & \multicolumn{4}{|c|}{ SÃO PAULO } & \multirow{2}{*}{$\begin{array}{c}\text { RIO DE JANEIRO } \\
\text { Centro de } \\
\text { Mediação Fórum } \\
\text { Central - setor } \\
\text { processual }\end{array}$} & \multirow{2}{*}{ 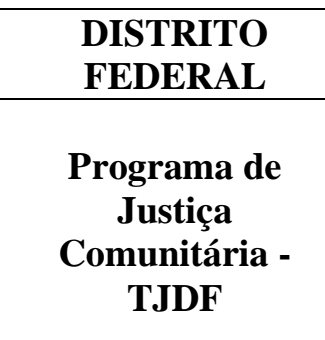 } \\
\hline FÓRUM & $\begin{array}{c}\text { Fórum Central } \\
\text { João Mendes - } \\
\text { Conciliação } \\
\text { pré-processual, } \\
\text { processual }\end{array}$ & $\begin{array}{c}\text { TJSP - Conciliação } \\
2^{\mathrm{a}} \text { instância }\end{array}$ & $\begin{array}{l}\text { Foro Regional } \\
\text { Pinheiros - } \\
\text { Conciliação pré- } \\
\text { processual e } \\
\text { processual }\end{array}$ & $\begin{array}{c}\text { Foro Regional de } \\
\text { Santana - } \\
\text { Mediação pré- } \\
\text { processual e } \\
\text { processual }\end{array}$ & & \\
\hline $\begin{array}{c}\text { As partes } \\
\text { precisam estar } \\
\text { presentes na } \\
\text { sessão de } \\
\text { mediação/ } \\
\text { conciliação? }\end{array}$ & $\begin{array}{c}\text { Não. Elas podem } \\
\text { estar representadas } \\
\text { pelos seus } \\
\text { advogados. }\end{array}$ & $\begin{array}{c}\text { Não, mas se } \\
\text { recomenda que as } \\
\text { partes ou prepostos } \\
\text { da empresa estejam } \\
\text { presentes. }\end{array}$ & $\begin{array}{c}\text { Não, elas podem } \\
\text { estar representadas } \\
\text { pelos seus } \\
\text { advogados, } \\
\text { com poderes para } \\
\text { transigir. }\end{array}$ & $\begin{array}{l}\text { Sim, ambas as partes } \\
\text { precisam estar } \\
\text { presentes. }\end{array}$ & $\begin{array}{l}\text { Sim, ambas as partes } \\
\text { precisam estar } \\
\text { presentes. }\end{array}$ & $\begin{array}{c}\text { Sim. Se umas das } \\
\text { partes não estiver } \\
\text { presente a mediação } \\
\text { não acontece. }\end{array}$ \\
\hline $\begin{array}{c}\text { Podem as } \\
\text { partes trazer à } \\
\text { mediação } \\
\text { outras pessoas } \\
\text { para suporte } \\
\text { emocional? }\end{array}$ & $\begin{array}{l}\text { Sim, às vezes a } \\
\text { presença do } \\
\text { acompanhante é } \\
\text { importante para } \\
\text { auxiliar a parte } \\
\text { inclusive no } \\
\text { cumprimento do } \\
\text { compromisso } \\
\text { assumido. }\end{array}$ & $\begin{array}{l}\text { Sim, se não houver } \\
\text { objeção da outra } \\
\text { parte e se o terceiro } \\
\text { tiver alguma relação } \\
\text { com o caso em } \\
\text { discussão. }\end{array}$ & $\begin{array}{c}\text { No expediente } \\
\text { processual, não. No } \\
\text { expediente pré- } \\
\text { processual, sim, } \\
\text { uma vez que a lide } \\
\text { não foi formada. } \\
\text { No entanto, pede-se } \\
\text { permissão à parte } \\
\text { adversa. }\end{array}$ & $\begin{array}{l}\text { Sim. São chamados } \\
\text { de terceiros } \\
\text { colaboradores. Se } \\
\text { forem colaborar, e } \\
\text { todos concordarem, } \\
\text { serão sempre bem } \\
\text { vindos. }\end{array}$ & Sim & $\begin{array}{l}\text { Sim, é possível } \\
\text { trazer } \\
\text { acompanhantes que } \\
\text { possam contribuir e } \\
\text { facilitar o diálogo } \\
\text { entre as partes. }\end{array}$ \\
\hline $\begin{array}{c}\text { O programa } \\
\text { coleta } \\
\text { informações se } \\
\text { é a } 1^{\mathrm{a}} \text { vez que } \\
\text { as partes se } \\
\text { submetem à }\end{array}$ & $\begin{array}{l}\text { Não (muito embora } \\
\text { essa informação } \\
\text { possa aparecer } \\
\text { durante o } \\
\text { atendimento no setor } \\
\text { pré-processual) }\end{array}$ & $\begin{array}{l}\text { Não, somente se ela } \\
\text { ocorreu também no } \\
\text { Setor. }\end{array}$ & $\begin{array}{c}\text { O conciliador } \\
\text { costuma, no início } \\
\text { da sessão, } \\
\text { perguntar às partes } \\
\text { se já participaram } \\
\text { de alguma }\end{array}$ & $\begin{array}{l}\text { Sim, a informação é } \\
\text { fornecida pelos } \\
\text { mediandos. }\end{array}$ & ND & ND \\
\hline
\end{tabular}




\begin{tabular}{|c|c|c|c|c|c|c|}
\hline mediação? & & & $\begin{array}{c}\text { audiência de } \\
\text { conciliação e, em } \\
\text { caso negativo, } \\
\text { explica a elas sobre } \\
\text { o procedimento. }\end{array}$ & & & \\
\hline $\begin{array}{c}\text { São comuns } \\
\text { nos programas } \\
\text { disputas com } \\
\text { múltiplas } \\
\text { partes? E } \\
\text { ações } \\
\text { coletivas? }\end{array}$ & $\begin{array}{l}\text { Sim, pode haver } \\
\text { várias partes, } \\
\text { principalmente nos } \\
\text { casos envolvendo } \\
\text { condomínios. }\end{array}$ & $\begin{array}{l}\text { Não. É mais comum } \\
\text { a existência de } \\
\text { várias ações entre as } \\
\text { mesmas partes, que } \\
\text { podem ser objeto do } \\
\text { acordo. }\end{array}$ & $\begin{array}{c}\text { Sim, pode haver } \\
\text { várias partes tanto } \\
\text { no processual como } \\
\text { no pré-processual, } \\
\text { mas nunca houve } \\
\text { ação coletiva. } \\
\text { É mais comum a } \\
\text { existência de várias } \\
\text { ações entre as } \\
\text { mesmas partes. }\end{array}$ & $\begin{array}{l}\text { Sim, pode haver } \\
\text { várias partes. Um } \\
\text { exemplo disso é o } \\
\text { inventário com } \\
\text { múltiplos herdeiros. }\end{array}$ & ND & $\begin{array}{c}\text { Já houve no } \\
\text { programa algumas } \\
\text { mediações } \\
\text { envolvendo várias } \\
\text { partes (alguns casos } \\
\text { de convivência } \\
\text { familiar e, } \\
\text { recentemente, um } \\
\text { caso envolvendo } \\
\text { vários moradores de } \\
\text { um condomínio). }\end{array}$ \\
\hline $\begin{array}{c}\text { O programa } \\
\text { oferece algum } \\
\text { tratamento } \\
\text { diferenciado } \\
\text { quando há } \\
\text { desníveis de } \\
\text { poder entre as } \\
\text { partes? }\end{array}$ & $\begin{array}{c}\text { Esta é uma das } \\
\text { atribuições do } \\
\text { conciliador, que deve } \\
\text { orientar a parte que } \\
\text { estiver em desnível } \\
\text { para que não venha a } \\
\text { assumir um } \\
\text { compromisso que } \\
\text { não tenha entendido } \\
\text { e/ou não tenha } \\
\text { condições de } \\
\text { honrar }^{328} \text {. }\end{array}$ & $\begin{array}{l}\text { Não há regra para } \\
\text { isso, mas o bom } \\
\text { conciliador atentará } \\
\text { para o fato e } \\
\text { procurará diminuir o } \\
\text { desequilíbrio, se } \\
\text { possível. }\end{array}$ & $\begin{array}{l}\text { Esta é uma das } \\
\text { atribuições do } \\
\text { conciliador, que } \\
\text { pergunta se a parte } \\
\text { está confortável } \\
\text { para “fechar" um } \\
\text { acordo. }\end{array}$ & $\begin{array}{l}\text { Esta é uma das } \\
\text { atribuições do } \\
\text { mediador, para que } \\
\text { se abra o canal de } \\
\text { comunicação entre } \\
\text { os mediandos. }\end{array}$ & $\begin{array}{l}\text { Sim, deve haver um } \\
\text { cuidado especial. } \\
\text { Em casos de } \\
\text { desequilíbrio de } \\
\text { poder, a mediação } \\
\text { pode não ser } \\
\text { realizada. }\end{array}$ & $\begin{array}{l}\text { Sim, nesse caso há } \\
\text { um } \\
\text { acompanhamento e } \\
\text { encaminhamento à } \\
\text { educação jurídica } \\
\text { (fora da mediação) }\end{array}$ \\
\hline
\end{tabular}

\footnotetext{
${ }^{328}$ Algumas poucas vezes o entrevistado relata que já tiveram que solicitar o comparecimento de um advogado na sessão de conciliação para que orientasse juridicamente a parte que estava desassistida e também insegura quanto aos termos da sessão, enfatizando que o profissional estaria atuando como orientador e não como defensor.
} 


\section{vi. Papel do Juiz}

\begin{tabular}{|c|c|c|c|c|c|c|}
\hline CIDADE & \multicolumn{4}{|c|}{ SÃO PAULO } & \multirow{2}{*}{$\begin{array}{c}\text { RIO DE JANEIRO } \\
\text { Centro de } \\
\text { Mediação Fórum } \\
\text { Central - setor } \\
\text { processual }\end{array}$} & \multirow{2}{*}{$\begin{array}{c}\text { DISTRITO } \\
\text { FEDERAL } \\
\text { Programa de } \\
\text { Justiça } \\
\text { Comunitária - } \\
\text { TJDF }\end{array}$} \\
\hline FÓRUM & $\begin{array}{c}\text { Fórum Central João } \\
\text { Mendes - } \\
\text { Conciliação } \\
\text { pré-processual, } \\
\text { processual }\end{array}$ & $\begin{array}{c}\text { TJSP - Conciliação } \\
2^{\mathrm{a}} \text { instância }\end{array}$ & $\begin{array}{c}\text { Foro Regional } \\
\text { Pinheiros - } \\
\text { Conciliação pré- } \\
\text { processual e } \\
\text { processual } \\
\end{array}$ & $\begin{array}{c}\text { Foro Regional de } \\
\text { Santana - } \\
\text { Mediação pré- } \\
\text { processual e } \\
\text { processual } \\
\end{array}$ & & \\
\hline $\begin{array}{c}\text { Pode o juiz } \\
\text { direcionar o } \\
\text { caso à } \\
\text { mediação? }\end{array}$ & Sim & Sim (o relator) & Sim & Sim & Sim & Não \\
\hline $\begin{array}{c}\text { Como é o } \\
\text { envolvimento } \\
\text { do juiz } \\
\text { durante a } \\
\text { mediação? }\end{array}$ & $\begin{array}{l}\text { Não há envolvimento } \\
\text { do juiz. Pode ser feito } \\
\text { apenas um controle } \\
\text { estatístico, de dados } \\
\text { formais e resultados } \\
\text { dos processos } \\
\text { enviados ao Setor. Os } \\
\text { processos retornam à } \\
\text { Vara de origem em } \\
24 \text { horas após a } \\
\text { sessão. }\end{array}$ & $\begin{array}{l}\text { Não há } \\
\text { envolvimento do } \\
\text { juiz. }\end{array}$ & $\begin{array}{c}\text { Não há } \\
\text { envolvimento do } \\
\text { juiz. Somente no } \\
\text { caso de dúvida } \\
\text { quanto a acordos } \\
\text { formulados e sua } \\
\text { devida } \\
\text { homologação, o } \\
\text { juiz é consultado } \\
\text { sobre como se pode } \\
\text { proceder. }\end{array}$ & $\begin{array}{l}\text { Não há } \\
\text { envolvimento do } \\
\text { juiz. }\end{array}$ & $\begin{array}{l}\text { Não há } \\
\text { envolvimento do } \\
\text { juiz. }\end{array}$ & $\begin{array}{c}\text { Não há } \\
\text { envolvimento. As } \\
\text { Juízas que } \\
\text { coordenam } \\
\text { institucionalmente o } \\
\text { Programa não } \\
\text { participam de } \\
\text { nenhuma sessão de } \\
\text { mediação. Seu papel } \\
\text { é apenas coordenar e } \\
\text { representar o } \\
\text { Programa, } \\
\text { promover parcerias } \\
\text { e convênios com } \\
\text { entidades nacionais } \\
\text { e internacionais. }\end{array}$ \\
\hline
\end{tabular}




\section{vii. Papel do Mediador/Conciliador}

\begin{tabular}{|c|c|c|c|c|c|c|}
\hline \multirow{2}{*}{$\begin{array}{l}\text { CIDADE } \\
\text { FÓRUM }\end{array}$} & \multicolumn{4}{|c|}{ SÃO PAULO } & \multirow{2}{*}{$\begin{array}{c}\text { RIO DE JANEIRO } \\
\text { Centro de } \\
\text { Mediação Fórum } \\
\text { Central - setor } \\
\text { processual }\end{array}$} & \multirow{2}{*}{$\begin{array}{c}\text { DISTRITO } \\
\text { FEDERAL } \\
\text { Programa de } \\
\text { Justiça } \\
\text { Comunitária - } \\
\text { TJDF } \\
\end{array}$} \\
\hline & $\begin{array}{c}\text { Fórum Central João } \\
\text { Mendes - } \\
\text { Conciliação } \\
\text { pré-processual, } \\
\text { processual } \\
\end{array}$ & $\begin{array}{c}\text { TJSP - Conciliação } \\
2^{\mathrm{a}} \text { instância }\end{array}$ & $\begin{array}{c}\text { Foro Regional } \\
\text { Pinheiros - } \\
\text { Conciliação pré- } \\
\text { processual e } \\
\text { processual } \\
\end{array}$ & $\begin{array}{c}\text { Foro Regional de } \\
\text { Santana - } \\
\text { Mediação pré- } \\
\text { processual e } \\
\text { processual } \\
\end{array}$ & & \\
\hline $\begin{array}{l}\text { Precisa ser } \\
\text { formado em } \\
\text { direito? Qual é } \\
\text { a formação } \\
\text { dos } \\
\text { mediadores? }\end{array}$ & $\begin{array}{l}\text { O conciliador não } \\
\text { precisa ser advogado. } \\
\text { Pode ser psicólogo, } \\
\text { assistente social, } \\
\text { funcionário público } \\
\text { aposentado, policial, } \\
\text { dentre outros, } \\
\text { conforme autoriza o } \\
\text { Provimento } \\
\text { 953/2005 }\end{array}$ & $\begin{array}{c}\text { Segundo o } \\
\text { provimento } \\
\text { 843/2004, podem ser } \\
\text { conciliadores os } \\
\text { magistrados, } \\
\text { membros do MP e } \\
\text { Procuradores do } \\
\text { Estado, todos } \\
\text { aposentados, além } \\
\text { de professores } \\
\text { universitários e } \\
\text { advogados }^{330} \text {. }\end{array}$ & $\begin{array}{l}\text { O conciliador não } \\
\text { precisa ser } \\
\text { advogado. Pode ser } \\
\text { assistente social, } \\
\text { biólogo, } \\
\text { engenheiro, dentre } \\
\text { outras formações. } \\
\text { Em sua grande } \\
\text { maioria, são } \\
\text { profissionais } \\
\text { liberais e há alguns } \\
\text { aposentados. }\end{array}$ & $\begin{array}{l}\text { O mediador que atua } \\
\text { no setor pode ter } \\
\text { diferentes } \\
\text { formações. Não } \\
\text { precisa ser } \\
\text { advogado, mas todos } \\
\text { precisam ter } \\
\text { capacitação prévia e } \\
\text { seus nomes são } \\
\text { aprovados pelos } \\
\text { Juízes das Varas do } \\
\text { Fórum Regional de } \\
\text { Santana. }\end{array}$ & $\begin{array}{c}\text { Os mediadores } \\
\text { podem ter diferentes } \\
\text { formações: } \\
\text { assistentes sociais, } \\
\text { advogados, } \\
\text { psicólogos, } \\
\text { serventuários da } \\
\text { justiça, dentre } \\
\text { outros. É requisito } \\
\text { para ser mediador } \\
\text { ter nível superior de } \\
\text { ensino e ter feito a } \\
\text { capacitação. }\end{array}$ & $\begin{array}{c}\text { Os mediadores são } \\
\text { os agentes } \\
\text { comunitários que, na } \\
\text { qualidade de } \\
\text { membros das } \\
\text { comunidades nas } \\
\text { quais atuam, } \\
\text { compartilham a } \\
\text { linguagem e o } \\
\text { código de valores } \\
\text { comunitários. } \\
\text { Eles podem ter } \\
\text { diferentes } \\
\text { formações. } \\
\end{array}$ \\
\hline $\begin{array}{c}\text { São } \\
\text { funcionários } \\
\text { ou contratados }\end{array}$ & $\begin{array}{c}\text { Não. Os } \\
\text { conciliadores não têm } \\
\text { vínculo empregatício }\end{array}$ & $\begin{array}{c}\text { Não. Os } \\
\text { conciliadores não } \\
\text { têm vínculo } \\
\end{array}$ & $\begin{array}{c}\text { Não. Os } \\
\text { conciliadores não } \\
\text { têm vínculo } \\
\end{array}$ & $\begin{array}{l}\text { Não. Os mediadores } \\
\text { não têm vínculo } \\
\text { empregatício com o }\end{array}$ & $\begin{array}{l}\text { Não. Os mediadores } \\
\text { não têm vínculo } \\
\text { empregatício com o }\end{array}$ & $\begin{array}{l}\text { Não. Os mediadores } \\
\text { não têm vínculo } \\
\text { empregatício com o }\end{array}$ \\
\hline
\end{tabular}

${ }^{329}$ Muitos advogados que estão prestando concurso são conciliadores, pois esta atividade conta como tempo de exercício da advocacia para fins do concurso (vide art. 58 da Resolução no $75 / 2009$ e Enunciado Administrativo no 3 do Conselho Nacional de Justiça).

${ }^{330}$ Estes conciliadores, todos com larga experiência, reconhecida capacidade e reputação ilibada, são selecionados pela Comissão Supervisora e designados pelo Presidente do Tribunal de Justiça, como conciliadores honorários, exercendo atividade não remunerada. Os conciliadores advogados do setor tem mais de 20 anos de exercício da advocacia. Foram mantidos no setor aqueles que já vinham atuando na fase experimental durante o Plano Piloto. 


\begin{tabular}{|c|c|c|c|c|c|c|}
\hline pela Corte? & $\begin{array}{l}\text { com o Tribunal, } \\
\text { exercendo atividade } \\
\text { voluntária e não } \\
\text { remunerada. }\end{array}$ & $\begin{array}{l}\text { empregatício com o } \\
\text { Tribunal, exercendo } \\
\text { atividade voluntária } \\
\text { e não remunerada. }\end{array}$ & $\begin{array}{l}\text { empregatício com o } \\
\text { Tribunal, } \\
\text { exercendo } \\
\text { atividade voluntária } \\
\text { e não remunerada. }\end{array}$ & $\begin{array}{l}\text { Tribunal, exercendo } \\
\text { atividade voluntária } \\
\text { e não remunerada. }\end{array}$ & $\begin{array}{l}\text { Tribunal, exercendo } \\
\text { atividade voluntária } \\
\text { e não remunerada. }\end{array}$ & $\begin{array}{c}\text { Tribunal e não } \\
\text { exercem atividade } \\
\text { remunerada, mas há } \\
\text { o reembolso de } \\
\text { algumas despesas, } \\
\text { como de transporte. }\end{array}$ \\
\hline $\begin{array}{c}\text { Qual é o } \\
\text { gênero e a } \\
\text { idade média } \\
\text { dos } \\
\text { mediadores? }\end{array}$ & $\begin{array}{l}\text { Não há estatísticas } \\
\text { oficiais a respeito. } \\
\text { Varia muito. } \\
\text { Atualmente há } \\
\text { conciliadores entre } 25 \\
\text { e } 60 \text { anos. }\end{array}$ & $\begin{array}{l}\text { No cadastro atual } \\
\text { predomina a faixa } \\
\text { etária acima dos } 40 \\
\text { anos e uma média de } \\
50 \% \text { de homens e } \\
50 \% \text { de mulheres. }\end{array}$ & $\begin{array}{c}\text { No setor de } \\
\text { conciliação de } \\
\text { Pinheiros há muita } \\
\text { diversidade, mas a } \\
\text { maioria dos } \\
\text { conciliadores é do } \\
\text { sexo feminino. }\end{array}$ & $\begin{array}{l}\text { Em Santana, são } 15 \\
\text { mediadores, sendo } \\
\text { apenas um homem, } \\
\text { e } 14 \text { mulheres. A } \\
\text { faixa etária é de } 30 \text { a } \\
\quad 40 \text { anos. }\end{array}$ & ND & $\begin{array}{c}\text { Normalmente são } \\
\text { mulheres, de meia } \\
\text { idade, donas de casa } \\
\text { ou aposentadas. }\end{array}$ \\
\hline $\begin{array}{c}\text { Há algum } \\
\text { treinamento } \\
\text { ou capacitação } \\
\text { necessária? }\end{array}$ & $\begin{array}{l}\text { O conciliador deve } \\
\text { assistir a palestras de } \\
\text { treinamento com } \\
\text { duração de } 3 \text { horas } \\
\text { (estas palestras são } \\
\text { dadas por } 3 \\
\text { funcionários que } \\
\text { atuam em } 1^{\mathrm{a}} \text { instância } \\
\text { e foram treinados } \\
\text { pelo CNJ). Não há } \\
\text { reciclagem }{ }^{331} \text {. }\end{array}$ & $\begin{array}{l}\text { O Tribunal não } \\
\text { colocou a } \\
\text { capacitação como } \\
\text { requisito essencial, } \\
\text { mas na entrevista } \\
\text { isso é questionado. }\end{array}$ & $\begin{array}{c}\text { Sim, é necessário } \\
\text { que o conciliador } \\
\text { tenha feito algum } \\
\text { curso de } \\
\text { capacitação, } \\
\text { ficando submetido } \\
\text { às regras do órgão } \\
\text { que promoveu o } \\
\text { curso. }\end{array}$ & $\begin{array}{c}\text { Sim. } 90 \text { horas } \\
\text { teóricas e } 50 \\
\text { práticas, de acordo } \\
\text { com o projeto de } \\
\text { implantação do } \\
\text { Setor de Mediação } \\
\text { de Santana. Há um } \\
\text { processo de } \\
\text { habilitação, com } \\
\text { requisitos mínimos. } \\
\text { Após esse } 1^{\circ} \text { passo, } \\
\text { o mediador faz } \\
\text { entrevista com a } \\
\text { Juíza e } \\
\text { Coordenadora do }\end{array}$ & $\begin{array}{l}\text { Sim. Os mediadores } \\
\text { precisam fazer o } \\
\text { curso básico de } \\
\text { formação em } \\
\text { mediação e estar } \\
\text { inseridos no } \\
\text { processo de } \\
\text { certificaçãa } \\
\text { regulamentado por } \\
\text { Orgão Especial - } \\
\text { Subgrupo de } \\
\text { Trabalho para a } \\
\text { Conciliação e } \\
\text { Mediação do } \\
\text { TJRJ }{ }^{332} \text {. }\end{array}$ & $\begin{array}{c}\text { O Centro de } \\
\text { Formação e } \\
\text { Pesquisa em Justiça } \\
\text { Comunitária } \\
\text { (Escola), que integra } \\
\text { o Programa de } \\
\text { Justiça Comunitária, } \\
\text { tem como objetivo } \\
\text { promover a } \\
\text { formação e } \\
\text { capacitação da } \\
\text { equipe profissional e } \\
\text { dos agentes } \\
\text { comunitários, com } \\
\text { atividades teóricas e }\end{array}$ \\
\hline
\end{tabular}

${ }^{331}$ Além de fazer o curso, o conciliador deve apresentar currículo e será providenciada pelo Setor de Conciliação certidão de antecedentes cíveis e criminais, sendo nomeado pelo juiz como conciliador.

${ }^{332}$ Há convênio, firmado com o Ministério da Justiça, por intermédio da Secretaria de Reforma do Judiciário (MJ No 82/2008), para realização de cursos de capacitação e aperfeiçoamento em técnicas de mediação e composição de conflitos para magistrados e servidores do TJRJ. O curso de capacitação tem a duração de 40 horas, e a primeira turma é de janeiro de 2009. Tanto os mediadores como os juízes podem fazê-lo (neste último caso, tendo em vista a sensibilização dos juízes para encaminhamento dos casos ao Centro de Mediação). O exercício das funções de mediador certificado, por período contínuo superior a um ano, constitui relevante serviço público a ser anotado nos 


\begin{tabular}{|c|c|c|c|c|c|c|}
\hline & & & & Setor. & & $\begin{array}{l}\text { práticas constantes } \\
\text { sobre mediação } o^{333}\end{array}$ \\
\hline $\begin{array}{c}\text { Há } \\
\text { certificação de } \\
\text { mediadores? }\end{array}$ & Não & Não & Não & Não & Sim & Não \\
\hline $\begin{array}{l}\text { Como se dá a } \\
\text { escolha dos } \\
\text { mediadores? } \\
\text { Há alguma } \\
\text { lista nas } \\
\text { Cortes? }\end{array}$ & $\begin{array}{l}\text { No setor processual, a } \\
\text { distribuição dos casos } \\
\text { aos mediadores é } \\
\text { feita na hora do } \\
\text { pregão, por ordem de } \\
\text { chegada das partes e } \\
\text { aleatoriamente ao } \\
\text { mediador. No setor } \\
\text { pré-processual, os } \\
\text { casos são distribuídos } \\
\text { com base na escala } \\
\text { do dia. }\end{array}$ & $\begin{array}{l}\text { Há um cadastro de } \\
80 \text { conciliadores que } \\
\text { atuam no setor, a } \\
\text { maior parte } \\
\text { advogados. } O \\
\text { conciliador é } \\
\text { designado a partir do } \\
\text { dia de semana que } \\
\text { estará presente, ou } \\
\text { mesmo pelo perfil } \\
\text { do conciliador e } \\
\text { natureza do caso. }\end{array}$ & $\begin{array}{l}\text { Normalmente esta } \\
\text { escolha é feita pela } \\
\text { escala do dia da } \\
\text { semana. Os } \\
\text { conciliadores } \\
\text { atuam em rodízio. }\end{array}$ & $\begin{array}{l}\text { São } 15 \text { mediadores, } \\
\text { que atuam em } 4 \\
\text { grupos. Cada grupo } \\
\text { faz o seu próprio } \\
\text { rodízio, e os } \\
\text { critérios sobre os } \\
\text { dias de atuação são } \\
\text { consensuados. Não } \\
\text { há lista de } \\
\text { mediadores. }\end{array}$ & $\begin{array}{c}\text { A designação dos } \\
\text { mediadores é feita } \\
\text { preferencialmente, } \\
\text { em rodízio (cada } \\
\text { mediador atua em } \\
\text { um dia da semana), } \\
\text { observando-se a } \\
\text { disponibilidade de } \\
\text { horários e sua } \\
\text { adequação às } \\
\text { necessidades das } \\
\text { partes. }\end{array}$ & $\begin{array}{l}\text { A atribuição do caso } \\
\text { ao agente } \\
\text { comunitário é } \\
\text { função da equipe } \\
\text { multidisciplinar, que } \\
\text { considera a área } \\
\text { técnica de atuação, o } \\
\text { local onde o agente } \\
\text { mora e a sua } \\
\text { condição de atuar } \\
\text { em determinado } \\
\text { caso. }\end{array}$ \\
\hline $\begin{array}{c}\text { É possível } \\
\text { mudar o } \\
\text { mediador no } \\
\text { curso do } \\
\text { procedimento? }\end{array}$ & ND & ND & ND & ND & ND & ND \\
\hline $\begin{array}{l}\text { O mediador / } \\
\text { conciliador } \\
\text { pode ser um } \\
\text { especialista na }\end{array}$ & Sim & Sim & Não & Não & $\mathrm{Sim}^{334}$ & Não \\
\hline
\end{tabular}

assentamentos funcionais do servidor, além de título em concurso público realizado no âmbito do Poder Judiciário do Estado, inclusive no de provas e títulos para ingresso na magistratura de carreira estadual e critério de desempate nesse, ou em qualquer concurso realizado por esse Poder. Quando exercida por bacharel em direito, é também considerada atividade jurídica para fins do art. 58 da Resolução 75/2009 do CNJ, desde que exercida por, no mínimo, 16 horas mensais no período de 1 ano.

${ }^{333}$ No início, a capacitação era feita por mediadores e professores de fora, mas recentemente os próprios agentes passaram a participar e a se apropriar desta fase de capacitação.

334 Sendo advogado, segundo a Resolução 19/2009, é defeso ao mediador orientar as partes a respeito de questões jurídicas, prerrogativa exclusiva dos advogados que eventualmente as assistam. 


\begin{tabular}{|c|c|c|c|c|c|c|}
\hline $\begin{array}{l}\text { matéria do } \\
\text { conflito? }\end{array}$ & & & & & & \\
\hline $\begin{array}{c}\text { Mediador } \\
\text { possui poderes } \\
\text { discricionários } \\
\text { (contempt of } \\
\text { Power)? }\end{array}$ & Não & Não & Não & Não & Não & Não \\
\hline $\begin{array}{c}\text { Mediador } \\
\text { pode relatar } \\
\text { ao Juiz algo } \\
\text { sobre a } \\
\text { mediação? } \\
\end{array}$ & $\begin{array}{l}\text { Não, em face da } \\
\text { confidencialidade. }\end{array}$ & $\begin{array}{c}\text { Não, em face da } \\
\text { confidencialidade. }\end{array}$ & $\begin{array}{c}\text { Não, em face da } \\
\text { confidencialidade. }\end{array}$ & $\begin{array}{c}\text { Não, em face da } \\
\text { confidencialidade. }\end{array}$ & $\begin{array}{c}\text { Não, em face da } \\
\text { confidencialidade, } \\
\text { sob pena de prática } \\
\text { do crime do art. } 154 \\
\text { do CP. }\end{array}$ & Não. \\
\hline $\begin{array}{c}\text { O programa } \\
\text { segue regras } \\
\text { sobre ética e } \\
\text { responsabilida } \\
\text { de dos } \\
\text { mediadores? }\end{array}$ & $\begin{array}{l}\text { De acordo com o } \\
\text { Provimento }{ }^{\circ} \\
\text { 953/05, aplicam-se } \\
\text { aos conciliadores os } \\
\text { mesmos casos de } \\
\text { impedimento e } \\
\text { suspeição previstos } \\
\text { em lei para os juízes } \\
\text { e auxiliares da } \\
\text { justiça. }\end{array}$ & $\begin{array}{l}\text { Não há regra fixada } \\
\text { a respeito, mas os } \\
\text { casos envolvendo a } \\
\text { atuação dos } \\
\text { conciliadores podem } \\
\text { ser levados à } \\
\text { apreciação da } \\
\text { Comissão } \\
\text { Coordenadora, com } \\
\text { a possibilidade de } \\
\text { excluí-lo. }\end{array}$ & $\begin{array}{l}\text { De acordo com o } \\
\text { Provimento }{ }^{\circ} \\
\text { 953/05, aplicam-se } \\
\text { aos conciliadores } \\
\text { os mesmos casos } \\
\text { de impedimento e } \\
\text { suspeição previstos } \\
\text { em lei para os } \\
\text { juízes e auxiliares } \\
\text { da justiça. Estas } \\
\text { regras vão ao } \\
\text { encontro do Código } \\
\text { de Ética do } \\
\text { Conima. }\end{array}$ & $\begin{array}{l}\text { Sim, de acordo com } \\
\text { o Provimento }{ }^{\circ} \\
\text { 953/05 e as regras } \\
\text { do Conima. No } \\
\text { projeto de Santana, } \\
\text { os mediadores são } \\
\text { equiparados aos } \\
\text { peritos. }\end{array}$ & $\begin{array}{l}\text { Ainda não há um } \\
\text { código de ética, mas } \\
\text { a viga mestra do } \\
\text { mesmo está na } \\
\text { Resolução no } \\
\text { 19/2009 }{ }^{335} \text {. }\end{array}$ & $\begin{array}{c}\text { No curso de } \\
\text { capacitação em } \\
\text { mediação, um dos } \\
\text { tópicos é sobre a } \\
\text { ética dos } \\
\text { mediadores, mas no } \\
\text { Programa não há um } \\
\text { código escrito. }\end{array}$ \\
\hline
\end{tabular}

\footnotetext{
${ }^{335}$ Referida resolução determina que o mediador está imune a qualquer tipo de responsabilização, civil ou criminal, decorrente do respectivo procedimento, salvo as hipóteses de má-fé, conduta imprópria ou de desrespeito aos direitos fundamentais, à segurança e propriedade das partes ou de terceiros. O mediador deve também se orientar pelos princípios da voluntariedade, eticidade, boa fé, confidencialidade e competência, sujeitando-se à eventual reparação de danos causados às partes e à perda da certificação do Tribunal.
} 
viii. Papel do Diretor/Administrador dos Programas

\begin{tabular}{|c|c|c|c|c|c|c|}
\hline CIDADE & \multicolumn{4}{|c|}{ SÃO PAULO } & \multirow{2}{*}{$\begin{array}{c}\text { RIO DE JANEIRO } \\
\text { Centro de } \\
\text { Mediação Fórum } \\
\text { Central - setor } \\
\text { processual }\end{array}$} & \multirow{2}{*}{$\begin{array}{c}\text { DISTRITO } \\
\text { FEDERAL } \\
\text { Programa de } \\
\text { Justiça } \\
\text { Comunitária - } \\
\text { TJDF }\end{array}$} \\
\hline FÓRUM & $\begin{array}{l}\text { Fórum Central } \\
\text { João Mendes - } \\
\text { Conciliação } \\
\text { pré-processual, } \\
\text { processual }\end{array}$ & $\begin{array}{c}\text { TJSP - Conciliação } \\
2^{\mathrm{a}} \text { instância }\end{array}$ & $\begin{array}{c}\text { Foro Regional } \\
\text { Pinheiros - } \\
\text { Conciliação pré- } \\
\text { processual e } \\
\text { processual } \\
\end{array}$ & $\begin{array}{c}\text { Foro Regional de } \\
\text { Santana - } \\
\text { Mediação pré- } \\
\text { processual e } \\
\text { processual }\end{array}$ & & \\
\hline $\begin{array}{c}O \\
\text { programa/setor } \\
\text { tem um } \\
\text { administrador } \\
\text { ou } \\
\text { coordenador? }\end{array}$ & $\begin{array}{l}\text { Sim. Além do juiz } \\
\text { coordenador, há o } \\
\text { diretor do Setor de } \\
\text { Conciliação Cível, } \\
\text { que também pode } \\
\text { atuar como } \\
\text { conciliador, se } \\
\text { houver necessidade. }\end{array}$ & $\begin{array}{l}\text { Sim. Além do grupo } \\
\text { de desembargadores } \\
\text { que coordena o } \\
\text { setor, e do } \\
\text { presidente da Sessão } \\
\text { de Direito Privado, } \\
\text { que homologa os } \\
\text { acordos obtidos, há } \\
\text { um diretor e } \\
\text { funcionário alocados } \\
\text { para trabalhar no } \\
\text { setor. }\end{array}$ & $\begin{array}{l}\text { Sim. Além do juiz } \\
\text { coordenador, há } \\
\text { uma diretoria, } \\
\text { criada quando o } \\
\text { setor foi organizado } \\
\text { em unidade } \\
\text { administrativa, em } \\
\text { 14/05/10, } \\
\text { juntamente com } \\
\text { dois cargos de } \\
\text { chefia. Todos são } \\
\text { funcionários do } \\
\text { TJSP. }\end{array}$ & $\begin{array}{l}\text { Sim. Além de dois } \\
\text { juízes } \\
\text { coordenadores, } \\
\text { há uma } \\
\text { coordenadora, que é } \\
\text { advogada e também } \\
\text { mediadora. }\end{array}$ & $\begin{array}{l}\text { Sim. Além do juiz } \\
\text { coordenador, } \\
\text { há um juiz diretor e } \\
\text { um funcionário } \\
\text { coordenador. }\end{array}$ & $\begin{array}{l}\text { Sim. Além das duas } \\
\text { juízas } \\
\text { coordenadoras, há } \\
\text { uma Coordenadora } \\
\text { Adjunta, uma } \\
\text { supervisora } \\
\text { administrativa e uma } \\
\text { Diretora do Centro } \\
\text { de Formação. }\end{array}$ \\
\hline $\begin{array}{l}\text { Quais são as } \\
\text { principais } \\
\text { atividades do } \\
\text { administrador? }\end{array}$ & $\begin{array}{l}\text { De acordo com o } \\
\text { Provimento } \\
\text { 953/2005, o } \\
\text { movimento do Setor } \\
\text { de Conciliação será } \\
\text { controlado pelo juiz } \\
\text { coordenador, de } \\
\text { modo a }\end{array}$ & $\begin{array}{c}\text { As principais } \\
\text { atribuições do setor } \\
\text { são: receber os autos } \\
\text { destinados à } \\
\text { conciliação; agendar } \\
\text { as sessões; convocar } \\
\text { as partes e os } \\
\text { conciliadores }\end{array}$ & $\begin{array}{l}\text { Um dos chefes é } \\
\text { responsável pelos } \\
\text { expedientes } \\
\text { processuais } \\
\text { (agendamento e } \\
\text { realização de } \\
\text { audiências, } \\
\text { organização da }\end{array}$ & $\begin{array}{c}\text { A coordenadora } \\
\text { seleciona os } \\
\text { mediadores para } \\
\text { integrarem a equipe, } \\
\text { está sempre atenta à } \\
\text { observância do } \\
\text { compromisso, } \\
\text { comprometimento }\end{array}$ & $\begin{array}{c}\text { Cabe ao } \\
\text { Coordenador do } \\
\text { Centro de Mediação } \\
\text { organizar as equipes } \\
\text { de mediação, fazer o } \\
\text { acompanhamento } \\
\text { administrativo dos } \\
\text { trabalhos }\end{array}$ & $\begin{array}{l}\text { Cabe aos juízes e } \\
\text { demais } \\
\text { coordenadores } \\
\text { representar o } \\
\text { Programa } \\
\text { Institucionalmente, } \\
\text { gerenciar suas } \\
\text { atividades e }\end{array}$ \\
\hline
\end{tabular}




\begin{tabular}{|c|c|c|c|c|c|c|}
\hline & $\begin{array}{l}\text { compatibilizá-lo } \\
\text { com a respectiva } \\
\text { estrutura material e } \\
\text { funcional. O juiz } \\
\text { coordenador poderá } \\
\text { exarar ordens de } \\
\text { serviço a partir do } \\
\text { dia-a-dia do setor e } \\
\text { homologa todos os } \\
\text { acordos obtidos. }\end{array}$ & $\begin{array}{l}\text { designados; lavrar } \\
\text { os termos de } \\
\text { audiências; remeter } \\
\text { os acordos para } \\
\text { homologação; } \\
\text { restituir os autos às } \\
\text { Varas de origem } \\
\text { após o registro do } \\
\text { acordo ou } \\
\text { providenciar a } \\
\text { devolução dos autos } \\
\text { à unidade onde ele } \\
\text { se encontrava. }\end{array}$ & $\begin{array}{l}\text { pauta) e outro pelos } \\
\text { expedientes pré- } \\
\text { processuais (desde } \\
\text { o atendimento até a } \\
\text { finalização de todo } \\
\text { o processo). A } \\
\text { diretoria é } \\
\text { responsável pela } \\
\text { distribuição e } \\
\text { fiscalização dos } \\
\text { serviços, } \\
\text { organização } \\
\text { administrativa e de } \\
\text { pessoal, dentre } \\
\text { outras atribuições. }\end{array}$ & $\begin{array}{l}\text { dos mediadores e } \\
\text { qualidade do } \\
\text { trabalho. Promove } \\
\text { encontro com } \\
\text { palestrantes que } \\
\text { possam contribuir } \\
\text { para o } \\
\text { aprimoramento } \\
\text { técnico dos } \\
\text { profissionais, dentre } \\
\text { outras atribuições. }\end{array}$ & $\begin{array}{c}\text { desenvolvidos, } \\
\text { acompanhar o } \\
\text { quadro de controle } \\
\text { de processos } \\
\text { atualizado } \\
\text { mensalmente pelo } \\
\text { apoio } \\
\text { administrativo, e } \\
\text { informado ao Juiz } \\
336\end{array}$ & $\begin{array}{c}\text { desenvolver } \\
\text { parcerias e } \\
\text { convênios com } \\
\text { entidades nacionais } \\
\text { e internacionais. }\end{array}$ \\
\hline $\begin{array}{c}\text { Qual é a } \\
\text { formação do } \\
\text { administrador? }\end{array}$ & $\begin{array}{l}\text { A Diretora do Setor } \\
\text { de Conciliação é } \\
\text { funcionária } \\
\text { cartorária, indicada } \\
\text { pelo Juiz } \\
\text { Coordenador para } \\
\text { tal função, tendo } \\
\text { participado do } \\
\text { treinamento dado } \\
\text { pelo TJ para todos } \\
\text { os conciliadores. }\end{array}$ & $\begin{array}{c}\text { A Diretora é } \\
\text { bacharel em Direito } \\
\text { e pós-graduada em } \\
\text { Mediação de } \\
\text { Conflitos. Sua } \\
\text { função no Setor de } \\
\text { Conciliação não é } \\
\text { mediar e sim dirigir } \\
\text { o Setor. Para isso, } \\
\text { utiliza sua } \\
\text { experiência como } \\
\text { dirigente de cartório. }\end{array}$ & $\begin{array}{c}\text { A Diretora é } \\
\text { bacharel em } \\
\text { Direito, exerceu a } \\
\text { advocacia durante } \\
\text { seis anos, antes de } \\
\text { ingressar no TJSP. } \\
\text { Fez o "VII Curso } \\
\text { de Capacitação em } \\
\text { Conciliação e } \\
\text { Mediação no } \\
\text { Judiciário" na } \\
\text { Escola Paulista da } \\
\text { Magistratura. }\end{array}$ & $\begin{array}{c}\text { A coordenadora é } \\
\text { advogada e pratica } \\
\text { mediação há } 7 \text { anos, } \\
\text { no fórum de } \\
\text { Itaquera, e há } 6 \\
\text { anos, em Santana. } \\
\text { Faz também } \\
\text { mediações privadas. } \\
\text { É docente em } \\
\text { universidades e } \\
\text { palestrante sobre o } \\
\text { tema. }\end{array}$ & ND & $\begin{array}{l}\text { A supervisora } \\
\text { administrativa é } \\
\text { Bacharel em } \\
\text { Ciências } \\
\text { Econômicas. }\end{array}$ \\
\hline
\end{tabular}

\footnotetext{
${ }^{336}$ Além da mediação processual, caberá aos Centros de Mediação a promoção de palestras, conferências, e cursos de final de semana destinados à educação comunitária, à formação e multiplicação de mediadores comunitários, dentre outras atividades previstas pela Resolução.
} 
ix. Outras questões e peculiaridades sobre os Programas de Mediação

\begin{tabular}{|c|c|c|c|c|c|c|}
\hline \multirow{2}{*}{$\begin{array}{l}\text { CIDADE } \\
\text { FÓRUM }\end{array}$} & \multicolumn{4}{|c|}{ SÃO PAULO } & \multirow{2}{*}{$\begin{array}{c}\text { RIO DE JANEIRO } \\
\text { Centro de } \\
\text { Mediação Fórum } \\
\text { Central - setor } \\
\text { processual }\end{array}$} & \multirow{2}{*}{$\begin{array}{c}\text { DISTRITO } \\
\text { FEDERAL } \\
\text { Programa de } \\
\text { Justiça } \\
\text { Comunitária - } \\
\text { TJDF }\end{array}$} \\
\hline & $\begin{array}{c}\text { Fórum Central João } \\
\text { Mendes - } \\
\text { Conciliação } \\
\text { pré-processual, } \\
\text { processual } \\
\end{array}$ & $\begin{array}{c}\text { TJSP - Conciliação } \\
2^{\mathrm{a}} \text { instância }\end{array}$ & $\begin{array}{c}\text { Foro Regional } \\
\text { Pinheiros - } \\
\text { Conciliação pré- } \\
\text { processual e } \\
\text { processual } \\
\end{array}$ & $\begin{array}{c}\text { Foro Regional de } \\
\text { Santana - } \\
\text { Mediação pré- } \\
\text { processual e } \\
\text { processual } \\
\end{array}$ & & \\
\hline Peculiaridades & $\begin{array}{l}\mathrm{O} \text { argumento sobre a } \\
\text { morosidade do } \\
\text { Judiciário aparece } \\
\text { com certa } \\
\text { regularidade durante } \\
\text { as sessões, quer seja } \\
\text { levantado pelo } \\
\text { conciliador quer pelas } \\
\text { partes e advogados. } \\
\text { No setor pré- } \\
\text { processual, o } \\
\text { processo de mediação } \\
\text { é digitalizado. }\end{array}$ & $\begin{array}{c}\text { Os advogados } \\
\text { muitas vezes } \\
\text { assumem } \\
\text { protagonismo nas } \\
\text { sessões de } \\
\text { conciliação, } \\
\text { fechando os termos } \\
\text { do acordo. } \\
\text { O argumento sobre a } \\
\text { morosidade do } \\
\text { Judiciário aparece } \\
\text { durante o } \\
\text { procedimento, } \\
\text { levantado pelas } \\
\text { partes, pelo } \\
\text { conciliador ou pelos } \\
\text { advogados. }\end{array}$ & $\begin{array}{l}\text { O argumento sobre } \\
\text { a morosidade do } \\
\text { Judiciário pode } \\
\text { aparecer, levantado } \\
\text { pelas partes e pelo } \\
\text { conciliador, para } \\
\text { avaliar os prós e } \\
\text { contras do acordo. } \\
\text { Percebe-se, em } \\
\text { muitos casos, que o } \\
\text { advogado pode } \\
\text { prejudicar a } \\
\text { realização do } \\
\text { acordo. }\end{array}$ & $\begin{array}{l}\text { Há em todos os } \\
\text { casos pré-mediação. } \\
\text { Não há a redação de } \\
\text { acordos no setor. } \\
\text { Havendo consenso } \\
\text { na mediação, são os } \\
\text { advogados que } \\
\text { redigem o acordo } \\
\text { fora da sessão, e } \\
\text { podem pedir a } \\
\text { homologação } \\
\text { judicial e a extinção } \\
\text { do processo, no caso } \\
\text { de mediação } \\
\text { incidental. }\end{array}$ & $\begin{array}{c}\text { O Centro de } \\
\text { Mediação atende aos } \\
\text { casos de família no } \\
\text { setor processual. } \\
\text { Mas a resolução } \\
\text { 19/2009, por outro } \\
\text { lado, determina que } \\
\text { a mediação pode ter } \\
\text { lugar antes mesmo } \\
\text { da distribuição da } \\
\text { ação, e pode se } \\
\text { estender também aos } \\
\text { processos de } \\
\text { natureza cível, } \\
\text { consumo, relações } \\
\text { de vizinhança, e } \\
\text { ações penais } \\
\text { privadas e públicas } \\
\text { acerca de infrações } \\
\text { de menor potencial } \\
\text { ofensivo. }\end{array}$ & $\begin{array}{c}\text { O objetivo deste } \\
\text { programa não é } \\
\text { reduzir demandas } \\
\text { que chegam ao } \\
\text { Judiciário, e sua } \\
\text { implementação pode } \\
\text { inclusive gerar uma } \\
\text { maior procura da } \\
\text { Justiça, diante da } \\
\text { conscientização das } \\
\text { partes acerca de seus } \\
\text { direitos. }\end{array}$ \\
\hline $\begin{array}{l}\text { Há controle } \\
\text { sobre repeat }\end{array}$ & $\begin{array}{l}\text { No setor pré- } \\
\text { processual, sim, }\end{array}$ & $\begin{array}{l}\text { Não há controle. Os } \\
\text { casos mais comuns }\end{array}$ & $\begin{array}{l}\text { Não há controle } \\
\text { sobre litigantes }\end{array}$ & $\begin{array}{l}\text { Não há controle. Os } \\
\text { casos mais comuns }\end{array}$ & $\begin{array}{c}\text { Não. O programa é } \\
\text { muito recente e }\end{array}$ & $\begin{array}{l}\text { Não. Há um controle } \\
\text { estatístico sobre o }\end{array}$ \\
\hline
\end{tabular}




\begin{tabular}{|c|c|c|c|c|c|c|}
\hline players? & $\begin{array}{c}\text { através de ordens de } \\
\text { serviço }{ }^{337} \text {. A grande } \\
\text { maioria dos casos } \\
\text { repetidos dizem } \\
\text { respeito a contratos } \\
\text { bancários (cartão de } \\
\text { crédito, } \\
\text { financiamento, } \\
\text { empréstimo) e } \\
\text { renegociação de } \\
\text { dívida. } \\
\text { Há litigância de } \\
\text { massa também em } \\
\text { relação a Eletropaulo, } \\
\text { Telefônica, Bancos e } \\
\text { Seguradoras. } \\
\text { No setor processual, } \\
\text { os litigantes mais } \\
\text { frequentes são } \\
\text { Instituições } \\
\text { Financeiras e } \\
\text { Condomínios. }\end{array}$ & $\begin{array}{c}\text { são aqueles em } \\
\text { maior volume no } \\
\text { Tribunal, sobre } \\
\text { contratos bancários, } \\
\text { compra e venda de } \\
\text { imóveis, e prestação } \\
\text { de serviços, } \\
\text { por exemplo. }\end{array}$ & $\begin{array}{l}\text { repetitivos. Hoje há } \\
\text { uma diversificação } \\
\text { grande de } \\
\text { litigantes. No início } \\
\text { do setor pré- } \\
\text { processual, havia } \\
\text { bastante litigância } \\
\text { em relação às } \\
\text { seguradoras. } \\
\text { Este setor é } \\
\text { procurado muitas } \\
\text { vezes pelo devedor } \\
\text { para renegociação } \\
\text { de dívida. }\end{array}$ & $\begin{array}{l}\text { estão relacionados a } \\
\text { questões familiares, } \\
\text { pessoas sofridas, } \\
\text { magoadas, } \\
\text { ressentidas e que, no } \\
\text { primeiro momento, } \\
\text { não querem } \\
\text { conversar. }\end{array}$ & $\begin{array}{l}\text { ainda não é possível } \\
\text { observar litigância } \\
\text { repetitiva. }\end{array}$ & $\begin{array}{c}\text { gênero e dados } \\
\text { sócio-econômicos } \\
\text { dos solicitantes, } \\
\text { renda familiar, } \\
\text { ocupação, idade e } \\
\text { grau de } \\
\text { escolaridade. } 75 \% \\
\text { das pessoas que } \\
\text { procuram o setor são } \\
\text { mulheres, 24\% } \\
\text { homens, a maior } \\
\text { parte com renda de } 1 \\
\text { a } 2 \text { salários } \\
\text { mínimos, com } \\
\text { diferentes níveis de } \\
\text { escolaridade. }\end{array}$ \\
\hline $\begin{array}{c}\text { Há alguma } \\
\text { pesquisa de } \\
\text { opinião após a } \\
\text { mediação } \\
\text { sobre a } \\
\text { satisfação das } \\
\text { partes com o } \\
\text { procedimento } \\
\text { e resultado? }\end{array}$ & $\begin{array}{l}\text { Não. Mas há dados } \\
\text { estatísticos sobre os } \\
\text { casos submetidos à } \\
\text { mediação. Todo mês } \\
\text { é elaborada estatística } \\
\text { e encaminhada à } \\
\text { Corregedoria Geral } \\
\text { do Tribunal de } \\
\text { Justiça. }\end{array}$ & $\begin{array}{l}\text { Não há pesquisa de } \\
\text { opinião, mas há um } \\
\text { questionário, } \\
\text { preparado pela } \\
\text { Presidência do } \\
\text { Tribunal, que é } \\
\text { preenchido pelo } \\
\text { setor e pelo } \\
\text { conciliador para fins } \\
\text { estatísticos }\end{array}$ & $\begin{array}{c}\text { Apenas } \\
\text { informalmente, o } \\
\text { que depende de } \\
\text { quem conduz a } \\
\text { audiência. Existe } \\
\text { uma estatística feita } \\
\text { todos os meses, } \\
\text { encaminhada ao } \\
\text { Tribunal, onde se } \\
\text { computam as }\end{array}$ & Sim & $\begin{array}{c}\text { Ainda não, mas há } \\
\text { previsão de se fazer } \\
\text { esta pesquisa, com } \\
\text { foco quantitativo e } \\
\text { qualitativo. }\end{array}$ & $\begin{array}{l}\text { Ainda não, mas já há } \\
\text { um formulário } \\
\text { pronto para ser } \\
\text { aplicado nesse } \\
\text { sentido. }\end{array}$ \\
\hline
\end{tabular}

${ }^{337}$ Cf. ordens de serviço 01/2008, 01/2009 e 03/2009, cujo inteiro teor está disponível no site www.tj.sp.gov.br, na pasta conciliação em 1ª instância. Acesso em 20/12/2010. 


\begin{tabular}{|c|c|c|c|c|c|c|}
\hline & & & $\begin{array}{c}\text { audiências } \\
\text { realizadas, } \\
\text { frutíferas, } \\
\text { infrutíferas, não } \\
\text { realizadas ou } \\
\text { canceladas. Sobre o } \\
\text { cumprimento } \\
\text { efetivo dos } \\
\text { acordos, não há } \\
\text { estatística. }\end{array}$ & & & \\
\hline $\begin{array}{l}\text { Características } \\
\text { do local em } \\
\text { que são } \\
\text { realizadas as } \\
\text { sessões de } \\
\text { mediação }\end{array}$ & $\begin{array}{c}\text { No setor pré- } \\
\text { processual, as } \\
\text { audiências ocorrem } \\
\text { fora do Fórum, mas } \\
\text { algumas regras do } \\
\text { Tribunal, inclusive } \\
\text { sobre os trajes das } \\
\text { partes, se aplicam ao } \\
\text { local. } \\
\text { No setor processual, } \\
\text { as audiências } \\
\text { ocorrem em uma das } \\
8 \text { salas de audiência } \\
\text { localizadas no Fórum } \\
\text { João Mendes, nas } \\
\text { imediações do } \\
\text { Cartório de } \\
\text { Conciliação Cível. }\end{array}$ & $\begin{array}{c}\text { O Setor de } \\
\text { Conciliação em } 2^{\circ} \\
\text { Grau está instalado } \\
\text { no } 13^{\circ} \text { andar do } \\
\text { Fórum João Mendes } \\
\text { Jr, com cinco salas } \\
\text { de sessão e uma } \\
\text { antessala onde as } \\
\text { partes podem iniciar } \\
\text { o diálogo. }\end{array}$ & $\begin{array}{c}\text { As sessões ocorrem } \\
\text { no próprio Fórum, } \\
\text { nas dependências } \\
\text { do setor. São } \\
\text { realizadas a portas } \\
\text { fechadas. }\end{array}$ & $\begin{array}{l}\text { As sessões ocorrem } \\
\text { no próprio Fórum, } \\
\text { nas dependências do } \\
\text { setor, em uma sala } \\
\text { montada pela } \\
\text { Coordenadora, com } \\
\text { sofás, mesa de } \\
\text { centro, bem } \\
\text { aconchegante. }\end{array}$ & $\begin{array}{l}\text { As sessões ocorrem } \\
\text { no Centro de } \\
\text { Mediação. De } \\
\text { acordo com a } \\
\text { Resolução 19/2009, } \\
\text { estes Centros serão } \\
\text { montados em } \\
\text { espaços próprios dos } \\
\text { Fóruns das } \\
\text { Comarcas-sedes e se } \\
\text { comporão, na } \\
\text { medida do possível, } \\
\text { de pelo menos } 3 \\
\text { salas de mediação, } \\
\text { mobiliadas com } \\
\text { mesas redondas, } \\
\text { antessala de espera e } \\
\text { uma sala de suporte } \\
\text { administrativo. }\end{array}$ & $\begin{array}{c}\text { A maioria das } \\
\text { mediações ocorrem } \\
\text { nos Núcleos } \\
\text { Comunitários de } \\
\text { Justiça e Cidadania, } \\
\text { localizados nos } \\
\text { Fóruns. Nada } \\
\text { impede que, se o } \\
\text { agente se sentir } \\
\text { seguro e à vontade, } \\
\text { as mediações sejam } \\
\text { feitas nos espaços } \\
\text { comunitários. } \\
\text { A equipe } \\
\text { multidisciplinar fica } \\
\text { no Núcleo e oferece } \\
\text { suporte técnico e } \\
\text { administrativo aos } \\
\text { agentes } \\
\text { comunitários, que } \\
\text { muitas vezes } \\
\text { preferem fazer a } \\
\text { mediação neste } \\
\text { local. }\end{array}$ \\
\hline
\end{tabular}




\section{INSTITUCIONALIZAÇÃO DA MEDIAÇÃO: DESAFIOS E LIMITES}

O objetivo deste capítulo é trazer à tona os desafios e limites que se colocam à institucionalização da mediação nos EUA e no Brasil. Dentre eles está a necessidade de se dar maior atenção ao momento de triagem dos conflitos para o seu encaminhamento à mediação, conhecido nos EUA como screening process.

A triagem dos conflitos é um momento sensível na institucionalização dos programas, pois nem todos os casos são adequados para a mediação, e uma boa seleção é essencial para que as partes confiem no processo e, consequentemente, nos resultados obtidos. Assim, é necessário haver a indicação dos critérios a adotar nessa triagem, a escolha de quem os define e quando devem ser aplicados. O próximo item analisa como a triagem vem ocorrendo, de acordo com os dados da pesquisa empírica, e como deveria ou poderia ocorrer.

O item 6.2 aborda os desafios relacionados à mentalidade e comportamentos daqueles que participam do processo de mediação, seus sujeitos ativos e passivos: as partes, os advogados, os mediadores, os juízes e administradores/coordenadores dos programas.

Por fim, o último item trata dos limites dos meios alternativos de solução de conflitos, através de um olhar externo sobre o papel da mediação e sua relação com o sistema judicial e um olhar interno sobre o procedimento e técnicas da mediação, considerando que a análise dos limites é essencial ao reconhecimento das potencialidades e vantagens desta forma de autocomposição de conflitos. 


\subsection{Maior atenção aos filtros e à triagem dos conflitos - Screening process}

\section{a) Como vem acontecendo?}

Observou-se na pesquisa empírica realizada que, sendo a mediação processual e voluntária, os casos são geralmente encaminhados ao programa de mediação pelo juiz ou a requerimento das partes, sendo em ambas as hipóteses realizada a triagem individualmente em cada caso.

Quando o encaminhamento é feito pelo juiz, o que ocorre na maioria das vezes, ele não prescinde do consentimento das partes envolvidas, mas é o juiz quem define e aplica os critérios para filtrar e selecionar os casos que vão para o setor de mediação/conciliação. Isso pode ser feito a qualquer tempo, embora em muitos programas tenha notado-se a preferência para que os encaminhamentos à mediação sejam realizados na fase inicial do processo, antes da instrução probatória, podendo ou não haver a suspensão dos prazos processuais.

Não há uma objetivação ou normatização de critérios para a triagem dos conflitos que vão à mediação. Quem a realiza (seja o juiz, as partes ou seus advogados) define e utiliza seus próprios critérios, de acordo com as circunstâncias do caso concreto. Alguns setores disponibilizam um formulário para encaminhamento e solicitação de mediação pelas partes.

A existência de relação continuada entre as partes é um critério que na prática é observado de forma recorrente nos casos que são encaminhados aos programas de mediação. Nos EUA, os casos envolvendo violência doméstica recebem maior atenção e preocupação durante a triagem prévia (o que foi observado nos programas da Flórida e de Maine). 
Além desta triagem feita caso a caso pelo juiz, pelas partes, seus advogados, ou mesmo pelos funcionários do programa de mediação, há um tipo de triagem mais geral que foi observada em programas de mediação no Estado da Flórida. Trata-se de uma ordem geral do Presidente do Tribunal direcionando todos os casos já contestados à mediação, salvo manifestação das partes em sentido contrário.

A triagem e realização da mediação tendem a ser pensadas de acordo com o gerenciamento do processo, para que a mediação possa observar o cronograma estabelecido no planejamento da demanda (nos programas pesquisados nos EUA em raros casos há prorrogação ou suspensão de prazo em face da mediação).

Os critérios utilizados para triagem também podem variar, assim como quem os define. Na fase experimental do setor de conciliação em $2^{\mathrm{a}}$ instância do TJSP, por exemplo, a triagem dos casos era feita pelos funcionários do próprio setor, nas hipóteses em que a sentença fosse parcialmente procedente e houvesse espaço para a conciliação. Depois se percebeu que mesmo as partes vencedoras em $1^{\text {a }}$ instância poderiam ter interesse na conciliação, uma vez interposto recurso pela outra parte, em face da demora no julgamento do recurso ou da possibilidade de reforma da decisão. Transferiu-se a triagem para o advogado, que, atualmente, deve realizá-la junto ao seu cliente e, querendo, pode requisitar a sessão de conciliação ao setor.

Nos programas pesquisados em Maine, por sua vez, sendo a mediação obrigatória, há uma presunção de que os casos são passíveis de mediação, salvo prova em contrario (presumptive mediation).

No caso da mediação obrigatória (getting the parties to the table), que não significa obrigatoriedade de as partes chegarem a um acordo, um dos argumentos utilizados em seu favor é que quando as partes precisam tomar a iniciativa de propor a mediação pode haver o receio de que esta iniciativa seja vista como aparente fraqueza pela outra parte, o que não ocorreria se o caso fosse direcionado à mediação pela própria Corte. Outro argumento apontado em favor da mediação obrigatória é que mesmo que as partes não estejam 
predispostas a negociar, desde que estejam de boa fé, um mediador experiente poderia tentar quebrar algumas barreiras e propiciar pelo menos uma discussão e entendimento proveitoso do caso.

Não se observou nos programas pesquisados nos EUA a mediação pré-processual, tal como existe em vários programas no Brasil. Por outro lado, a possibilidade de haver o direcionamento de casos e processos a mediações privadas, fora da Corte, existe nos programas norte-americanos e não foi observada em nenhum dos programas pesquisados no Brasil.

Nos setores pré-processuais de mediação/conciliação, a procura é feita diretamente por uma ou ambas as partes, sem a existência de processo judicial. Os fatos e as pretensões tendem a chegar nestes setores de forma menos estruturada, e há normalmente limitação de competência territorial pelo domicílio dos solicitantes (setores pré-processuais do João Mendes e de Pinheiros). Estes setores acabam concorrendo com os Juizados Especiais, e a sua pauta de até 30 dias costuma ser mais rápida e, consequentemente, mais atrativa do que a pauta do JEC.

No programa de Justiça Comunitária do Distrito Federal, por sua vez, a captação e seleção dos casos é feita no ambiente de convívio comunitário dos agentes (igrejas, eventos, conversas no bairro). $\mathrm{Na}$ fase de triagem, o agente comunitário marca o atendimento com o solicitante, ouve a história e preenche o formulário de atendimento, quando é caso de mediação. Assim, as partes procuram o programa de mediação por meio do agente comunitário correspondente à sua área de moradia, que leva o caso ao Centro Comunitário para discussão em conjunto com a tríade multidisciplinar e demais agentes comunitários que queiram participar. A pré-mediação é sempre com as partes em separado, e depois são realizadas as sessões de mediação, podendo haver o encaminhamento para a rede de atendimento (saúde, educação, Procon, Defensoria, dentre outros ${ }^{338}$ ).

\footnotetext{
${ }^{338}$ No Projeto Íntegra- Gênero e Família, voltado à mediação de conflitos em contextos de violência e crimes de gênero e família, também há uma rede de atendimento e encaminhamentos paralelos das mais diversas ordens: educacionais, habitacionais, previdenciários, para informações jurídicas, de saúde em geral e/ou especializados no tratamento de alcoolismo e demais adições, o que proporciona uma mínima estabilidade
} 


\section{b) Como poderia acontecer?}

É possível estabelecer critérios objetivos para a triagem dos conflitos no Judiciário e o seu direcionamento à mediação? Caso seja positiva esta resposta, quais deveriam ser estes critérios?

Instado a responder esta pergunta sobre os critérios que devem ser usados para identificar os casos que melhor se ajustem à mediação, o juiz americano Wayne Brazil considera que a resposta dependerá em parte de quais são os objetivos do programa de mediação, que tipo de serviços ele está designado a prover, e quais são os demais serviços oferecidos por outros programas e processos disponíveis no Judiciário. É a partir dessas questões e da definição de prioridades que os programas devem ser desenhados ${ }^{339}$.

O encaminhamento do conflito ao programa pode ser feito com base em critérios mais flexíveis aplicados caso a caso, ou com base em um conjunto de regras e categorias gerais que não consideram as especificidades do caso.

Este autor apresenta uma lista de critérios que poderiam ser adotados:

i. Tema ou assunto;

ii. Complexidade (necessidade de um planejamento e acompanhamento especial do caso);

iii. Nível de dificuldade de encontrar o ponto central da disputa e controvérsia a partir dos pedidos das partes e outros documentos;

iv. Número de partes;

v. Tipo de ação (exemplo: exclusão das ações coletivas);

material, moral e psicológica. Isso porque, conforme ressalta a coordenadora deste projeto, Célia Zapparolli, apenas em patamares de mínima estabilidade é possível a mediação. Cf. ZAPPAROLLI, Políticas Públicas de Justiça e a Mediação cit, p. 568.

${ }^{339}$ Cf. BRAZIL, Wayne. Institutionalizing ADR cit., pp. 108. 
vi. Tipo de partes (parte que está auto-representada, litigantes institucionais, litigantes repetitivos, seguradoras, etc);

vii. Relação entre as partes (exemplo: alguma necessidade de incentivar, preservar ou construir uma relação continuada);

viii. Valores discutidos na controvérsia;

ix. Tipo de demanda e pedido (declaratório, condenatório);

x. Características da relação entre os advogados (litigante? incomunicável?);

xi. Tempo e situação do caso (antigo? parado?);

xii. Nível do interesse pelo acordo;

xiii. Partes e advogados que não aparentam agir com razoabilidade;

xiv. Partes ou advogados que aparentam ter pouca segurança em suas habilidades para focar no mérito e nos valores envolvidos no caso;

xv. Partes que aparentam ter porca confiança em seus próprios advogados;

xvi. Casos em que as custas e taxas parecem estar proporcionalmente elevadas para o valor da causa;

xvii. Partes com preocupações especiais sobre privacidade e confidencialidade;

xviii. Casos politicamente sensíveis ou muito conhecidos pelo público (devem eles ser excluídos ou, em algumas circunstâncias, devem estes casos ser bem filtrados e direcionados para alguma forma de solução de conflitos alternativa ao Judiciário? Prestar especial atenção nestes tipos de casos para questões relacionadas à confidencialidade);

xix. Casos que implicam em importantes políticas públicas (eles devem ser excluídos?);

xx. Casos sobre temas mais atípicos e esotéricos em que seria difícil encontrar terceiros com especialidade ou sem conflito de interesses para analisar;

xxi. Natureza da disputa (mais intensa quanto aos fatos ou quanto ao direito?) (340 $^{340}$

\footnotetext{
340 Tradução livre. No original: i. Subject matter; ii. Complexity (e.g., need for specially tailored case development planning/monitoring); iii. How difficult it is to find the center of the dispute from the pleadings or other formal papers; iv. Number of parties; v. Form of actions (e.g., exclude class actions); vi. Nature of parties (e.g., parties in pro per, institutional litigants, repeat litigants, insurance carriers, etc); vii. Relationship between parties (e.g., some need or incentive to preserve or build and on-going relationship); viii. Amount in controversy; ix. Nature of principal relief sought (equitable, damages, declaratory); $x$. Character of relationship between counsel (fractious? uncommunicative?); xi. Age of case (old, immobile); xii. Level of interest in settlement; xiii. Parties or attorneys who appear to be unrealistic; xiv. Parties or
} 
Em Connecticut, o Comitê de Resolução de Disputas no Judiciário (Standing Committee on Dispute Resolution in the Courts) apresentou relatório em que a triagem dos conflitos (case screening) assume um papel bem importante.

O Comitê propõe que, com apenas algumas exceções, os conflitos sejam tidos como passíveis de solução através de processos alternativos ao Judiciário (presumptively engage in a dispute resolution process), sendo resguardada a possibilidade de opt out, desde que haja justa causa. Ao ingressar em juízo, assim, as partes receberiam um "menu de meios alternativos" (contendo avaliação neutra de terceiro, mediação, arbitragem, dentre outros) e teriam a oportunidade de escolher um dos processos deste "cardápio". Se as partes não conseguissem fazer esta escolha, seriam então encaminhadas a uma audiência com um funcionário responsável pela triagem (case screener). Se mesmo após esta audiência as partes não conseguissem fazer a escolha do processo, o caso então seria remetido para avaliação neutra de terceiro, dentro de determinado prazo.

Segundo este Comitê, no início da implementação do programa de mediação, o ideal seria que um percentual fixo dos casos fosse automaticamente direcionado para a audiência de triagem (screening conference), a fim de familiarizar as partes e seus advogados com o programa, opções e escolhas possíveis, assistindo-os na seleção do meio de solução mais adequado para o seu caso.

A triagem é considerada também como um processo voltado à educação dos advogados e litigantes sobre as opções de mecanismos de solução de conflitos existentes e as combinações possíveis entre estes mecanismos e o tipo de caso, necessidades e desejos das partes e de seus advogados. É importante que seja conferida assistência às partes e advogados para uma seleção informada e consciente sobre o meio de solução de conflito

attorneys who appear to lack confidence in their ability to reliably assess the merits/value of the case; xv. Parties who appear to lack confidence in their own lawyers; xvi. Cases where fees and costs seem out of proportion to value; xvii. Parties with special concerns about privacy/confidentiality; xviii. Politically sensitive / high profile cases (should they be excluded or, in some circumstances, might cases like this be well suited to some form of ADR? Pay close attention in these kinds of cases to issues related to confidentiality); xix. Cases that implicate important public policies (should they be excluded?); xx. Cases in esoteric subject matter where neutrals with expertise and without conflicts of interest might be especially hard to find; xxi. Nature of dispute (fact intensive or law intensive?). Cf. BRAZIL, Institutionalizating ADR cit., pp. 108-109. 
mais adequado para o seu caso, com um monitoramento estatístico e fiscalização destas triagens, que precisam ocorrer de acordo com um determinado prazo, e em conexão com o gerenciamento do processo.

Uma vez definidos os critérios, quem deve ser o responsável pela filtragem dos conflitos? Quem deve ser o case screener? O legislador, o juiz, os servidores do Tribunal, as partes, os advogados?

Hoje quem aplica e quem define os critérios para a triagem dos conflitos e seu encaminhamento à mediação é o juiz ou seus auxiliares, a partir do caso concreto. Tentemos explorar as outras possibilidades.

Fossem as partes ou seus advogados a definir estes critérios para a escolha da mediação ou mesmo de outra técnica de solução de conflitos, esta definição provavelmente passaria pela análise de: i. características do conflito; ii. interesses e posições das partes (que estão por trás das polarizações entre autor e réu, credor e devedor, parte e terceiro); iii. natureza da relação entre as partes (relação continuada ou pontual); iv. características e potencialidades de cada processo (confidencialidade, efeitos da decisão, análise técnica do caso, atuação do terceiro, criação de precedentes para futuros casos similares, etc); v. relação entre as variáveis de custo e tempo, dentre outras questões que, dependendo do caso, podem adicionar um ingrediente de estratégia processual do advogado.

Essas escolhas podem ser prévias ou posteriores ao advento do conflito. Previamente, durante a relação contratual, podem as partes escolher uma forma de solução de conflitos e redigir cláusula para a hipótese de eventualmente surgir algum litígio entre os contratantes. É o caso, por exemplo, da inclusão de cláusula arbitral nos contratos, cuja incidência tem aumentado bastante no Brasil, diferentemente da incidência de cláusulas de mediação. 
Nesse contexto, os critérios dependem de cada caso e da relação entre advogado e cliente, sendo difícil objetivá-los e tolher a liberdade, restringir ou orientar as escolhas possíveis em cada caso.

No caso de estabelecimento de critérios pelo legislador (ope legis), diferentemente das partes e do juiz, não se poderia considerar as especificidades do caso. Hoje os critérios que o legislador apresenta são geralmente relacionados à disponibilidade do direito, sem adentrar em qualquer detalhamento maior ${ }^{341}$. No sentido da definição pela negação, há a possibilidade de especificarem-se apenas os casos que não podem ser objeto de mediação. É o que faz, por exemplo, o Projeto de Lei sobre mediação que tramita no Congresso Brasileiro ( $\mathrm{PL} \mathrm{n}^{\circ}$ 94/2002), ao determinar que a mediação incidental será obrigatória no processo de conhecimento, salvo nos seguintes casos: i. na ação de interdição; ii. quando for autora ou ré pessoa de direito público e a controvérsia versar sobre direitos indisponíveis; iii. na falência, na recuperação judicial e na insolvência civil; iv. no inventário e no arrolamento; v. nas ações de imissão de posse, reivindicatória e de usucapião de bem imóvel; vi. na ação de retificação de registro público; vii. quando o autor optar pelo procedimento do juizado especial ou pela arbitragem; viii. na ação cautelar; ix. quando na mediação prévia, tiver ocorrido sem acordo nos cento e oitenta dias anteriores ao ajuizamento da ação. Muito embora não se concorde com o conteúdo destas hipóteses excludentes, muitas das quais constituem campos férteis para a realização da mediação, a possibilidade de definir apenas os casos que não devem ser objeto de mediação é uma via interessante para o Legislativo.

A Resolução no 125/2010 do CNJ, que dispõe sobre a Política Judiciária Nacional de tratamento adequado dos conflitos de interesse no âmbito do Poder Judiciário, determina que os Tribunais deverão assegurar que nos Centros Judiciários de Solução de Conflitos e Cidadania atuem servidores com dedicação exclusiva, todos capacitados em métodos consensuais de solução de conflitos e, pelo menos, um deles capacitado também para a

\footnotetext{
${ }^{341}$ No caso da lei de arbitragem, o seu $1^{\circ}$ artigo enfrenta a questão sobre quem (arbitrabilidade subjetiva) e em quais casos (arbitrabilidade objetiva) se pode optar pela realização da arbitragem, ao dispor, em termos bem amplos, que as pessoas capazes de contratar poderão valer-se da arbitragem para dirimir litígios relativos a direitos patrimoniais disponíveis.
} 
triagem e encaminhamento adequado de casos. Esta resolução já trouxe um importante avanço, ao olhar para esta questão tão sensível que é a triagem, havendo ainda necessidade de serem estabelecidos os critérios para que se realize a triagem dos conflitos.

Não há necessariamente uma incompatibilidade entre as formas de definir os critérios para a triagem dos conflitos por diferentes atores: i. pelo juiz ou seus auxiliares, em cada caso; ii. pelo requerimento das partes, através de seus advogados; iii. seguindo os critérios mínimos e as hipóteses em que não é possível haver a mediação, de acordo com o estabelecido em lei.

Humberto Pinho admite a triagem feita de forma conjunta por todos os operadores do direito, dos advogados aos juízes, não devendo ser a mediação utilizada indiscriminadamente, quer prévia, quer incidentalmente, em todos os processos. Isso de nada contribuiria ao acesso à justiça, sendo imprescindível que exista uma forma de triagem e filtragem no início do processo conflituoso ${ }^{342}$.

Independentemente de quem faça a triagem, é importante que os casos sejam analisados a partir de alguns critérios, para que o setor de mediação/conciliação não se transforme em um repositório de processos e não seja visto apenas como mais uma fase incidental no procedimento da ação ${ }^{343}$.

Segundo Paulo Eduardo Alves da Silva, a triagem dos conflitos não deve ser resumida à separação dos casos entre provável/improvável resolução amigável. Abrangeria também a identificação, logo no início do processo, dos casos complexos e que demandam produção probatória delicada, daqueles que versam sobre matérias pacificadas em

\footnotetext{
${ }^{342}$ Cf. PINHO, A mediação e a necessidade de sua sistematização cit, pp. 16-17.

${ }^{343}$ A partir das experiências dos setores de mediação/conciliação nas Comarcas de Patrocínio Paulista e Serra Negra, em São Paulo, uma das questões sensíveis a que se chegou é que "é necessário que o juiz, no controle das iniciais, encaminhe o processo para o setor de conciliação/mediação, criado somente para os casos em que efetivamente haja possibilidade de autocomposição, sob pena de transformar o setor de conciliação/mediação num repositório de processos”. Cf. GAJARDONI, ROMANO, LUCHIARI, O gerenciamento do processo cit., p. 20.
} 
jurisprudência, daqueles que já podem ser imediatamente resolvidos. Esta triagem poderia ser feita pelas partes ou pelo juízo, através de funcionários do Tribunal ${ }^{344}$.

Isso tudo estaria relacionado ao gerenciamento do processo pelo juiz e pelo juízo. Este mesmo autor elenca as seguintes técnicas relacionadas ao gerenciamento: envolvimento imediato do juiz com o processo, a seleção e triagem das demandas, a abertura para meios alternativos de solução e conflitos (mediação, conciliação, arbitragem, avaliação neutra de terceiros, etc), o planejamento do andamento, do custo e do tempo do processo, a desformalização das regras processuais, a adaptação do procedimento às circunstâncias do caso, a organização da estrutura judiciária e criação de novas funções de apoio ao juiz, o controle do fluxo de rotinas internas dos cartórios, a gestão e o aproveitamento dos recursos humanos, materiais e tecnológicos do juízo, dentre outras ${ }^{345}$.

Frank Sander e Lukasz Rozdeiczer entendem que a escolha da técnica adequada à solução do conflito é mais arte do que ciência, muito embora haja indicações práticas e teóricas relevantes para a constituição de um verdadeiro guia para uma boa escolha ${ }^{346}$.

Ao listar objetivos como a busca por celeridade, privacidade, redução de custos, manutenção de relação entre as partes, intervenção de terceiros, necessidade de uma solução vinculante, complexidade técnica do caso, nível de controle do processo e do resultado pelas partes, Sander e Rozdeiczer conferem pesos que revelam o nível de busca e atendimento destes objetivos pelas mais variadas técnicas compositivas de conflitos, pesos que se deve considerar tendo por base a priorização destes objetivos e interesses pelas partes, a partir do caso concreto ${ }^{347}$. Alguns destes objetivos estão relacionados ao processo e outros ao resultado substancial da demanda, havendo ainda alguns que impactam sobre ambos (como os custos).

\footnotetext{
${ }^{344}$ SILVA, Gerenciamento de processos cit., pp. 40-41

${ }^{345}$ Ibidem, p. 141.

346 SANDER, Frank. E. A., ROZDEICZER, Lukasz. Matching cases and dispute resolution procedures: detailed analysis leading to a mediation centered approach. Harvard Negotiation Law Review, vol. 11, 2006, p. 2.

${ }^{347}$ Ibidem, p. 12
} 
A tese sustentada por Sander e Rozdeiczer é a de que a mediação oferece benefícios para, prima facie, ser utilizada como técnica de solução de conflitos, quer para resolver consensualmente a disputa em questão, quer para indicar uma outra técnica que seja adequada ao conflito, clarificando os interesses das partes e o objeto da demanda, em um ambiente de flexibilidade procedimental (a user-friendly, mediation-centered approach) ${ }^{348}$. Assim, um processo menos invasivo e custoso como a mediação poderia tanto resolver o conflito quanto anteceder e informar a escolha por outro processo adequado. Salvo algumas contraindicações, os autores elencam uma série de benefícios para esta preferência pela mediação por ambas as partes, e sintetizam:

\begin{abstract}
Finalmente, se o processo mais apropriado para a disputa é definido como aquele que melhor satisfaça aos interesses de ambas as partes e crie uma repartição do bolo mais vantajosa (tendo mais probabilidade de produzir um resultado eficiente de acordo com a lei de Pareto), a mediação, tendo o potencial mais elevado no quesito criação de valores, deveria ser a primeira escolha processual ${ }^{349}$.
\end{abstract}

\title{
6.2 Cultura jurídica: sujeitos ativos e passivos das mudanças
}

Além do momento inicial de triagem, há desafios relacionados ao comportamento, aceitação e perspectiva daqueles que participam do processo de mediação: as partes, os advogados, os mediadores, os juízes e o juízo. Falou-se nos capítulos acima em mudanças legislativas, judiciais e institucionais em favor da mediação, mas nenhuma delas será possível se não estiverem acompanhadas de mudanças culturais, de comportamento e de mentalidade.

Assim, poderá haver - e é importante que ocorra - a criação de setores de conciliação/mediação, o encaminhamento dos conflitos a estes setores, e um momento procedimental e gerencial destinado à realização das sessões de mediação, mas caso as

\footnotetext{
${ }^{348}$ Sobre os macro e micro benefícios desta técnica, Ibidem, pp. 32-35.

349 Tradução livre. No original: Finally, if the most appropriate process for dispute is defined as the one that best satisfies the interests of both parties and creates the largest possible pie (has the largest probability of producing a Pareto efficient outcome), mediation, having the highest value-creating potential, should be the process of first choice. Ibidem, p.35.
} 
partes, os advogados, mediadores, juízes e juízo não se preparem para a autocomposição, com a profissionalização e capacitação do terceiro, tempo e dedicação à sessão, abertura dos advogados e das partes ao diálogo, assim como o esforço do juiz e juízo para a adoção de critérios adequados à triagem dos conflitos e à redução da pauta para a sessão de mediação, todos estes avanços legais e institucionais podem não se tornar efetivos, com o risco de criar apenas uma etapa procedimental e formal que mais afasta do que aproxima as partes da pacificação do conflito ${ }^{350}$. A seguir, alguns dados sobre a realidade, coletados a partir da pesquisa empírica, e que devem ser constantemente avaliados para pautar as necessárias adaptações e novos desafios que se colocam aos sujeitos destas mudanças.

\section{a) Partes e Advogados}

Conforme já exposto, a formação cultural dos operadores do direito é litigante, voltada predominantemente para a solução contenciosa e adjudicada dos conflitos, através do processo judicial. Ressalta Kazuo Watanabe que é esse o modelo ensinado pelas faculdades de direito do país e o modelo de profissional do direito exigido pelo mercado para as principais carreiras profissionais, como a advocacia, a magistratura, o ministério público e as procuradorias públicas, havendo uma cultura da sentença e não da pacificação $^{351}$.

Alguns advogados receiam ter uma perda de mercado com a expansão dos meios alternativos de solução de conflitos ou que o procedimento se torne ainda mais longo, entre outros receios já abordados anteriormente (perda da voz predominante no processo,

\footnotetext{
${ }^{350}$ Nesse mesmo sentido, Nancy Welsh e Bobbi MacAdoo consideram que a institucionalização da mediação não deve ser um fim em si mesma: Institutionalization, without more, does not ensure that any of courtconnected mediation's justice goals have been achieved. Cf. McAdoo, Welsh, Look before you leap cit., p. 408.

${ }^{351}$ WATANABE, Cultura da sentença cit. p. 685. A resolução $\mathrm{n}^{\circ} 125$, de 29/11/2010 do CNJ, tentando contribuir à reversão deste quadro, estabeleceu que cabe ao $\mathrm{CNJ}$ buscar a cooperação dos órgãos públicos competentes e das instituições públicas e privadas da área de ensino, para a criação de disciplinas que propiciem o surgimento da cultura da solução pacífica dos conflitos, de modo a assegurar que, nas Escolas de Magistratura, haja módulo voltado aos métodos consensuais de solução de conflitos, no curso de iniciação funcional e no curso de aperfeiçoamento.
} 
assunção do risco de exposição do cliente na sessão, saída da zona de conforto, mudanças nas formas de cobrança de honorários, etc).

Sob a perspectiva das partes, no Brasil os dados do Índice de Confiança na Justiça (ICJBrasil) revelam que quase metade dos entrevistados (41\%) declararam que já entraram com algum processo ou ação na Justiça - pessoalmente, ou alguém residente em seu domicílio $^{352}$. Conforme exposto, perguntados se uma vez em juízo aceitariam tentar um acordo reconhecido pelo Judiciário, através de outra pessoa que não o juiz, as respostas foram: $38 \%$ dos entrevistados disseram que sim, que aceitariam utilizar meios de solução de conflitos alternativos ao Judiciário (destaque-se que na faixa de renda mais elevada, superior a $\mathrm{R} \$ 6.120,01$, este percentual sobe para 45\%), mas a maioria respondeu negativamente, indicando que apesar da pouca confiança que tem no Judiciário ainda prefere utilizá-lo se comparado a soluções alternativas (mediação e conciliação, por exemplo) $)^{353}$.

No processo judicial, os advogados representam as partes, falam em nome delas e geralmente controlam a forma pela qual os pedidos e questões são apresentados em juízo, fazendo uma seleção do que é relevante e do que é irrelevante para o caso ${ }^{354}$. A mediação busca quebrar este paradigma, dando mais voz às partes e fazendo com que elas sejam

\footnotetext{
${ }^{352}$ Cf. Relatório ICJBrasil cit, p. 15.

${ }^{353}$ Cf. Relatório ICJBrasil cit., p. 22.

${ }^{354}$ Sobre a relação entre partes e advogados, vide SARAT, Austin; FELSTINER, William L. F. Divorce Lawyers and their clients: power and meaning in the legal process. NY: Oxford University Press, 1995; e COOLEY, John W. A advocacia na mediação. Tradução: René Loncan. Brasília: Editora Universidade de Brasília, 2001. Sobre o papel do advogado na mediação, vide ainda Juan Vezzulla, que destaca que o advogado é o profissional que a sociedade consulta quando busca resolver um conflito e que indica os caminhos para resolver legal e satisfatoriamente o problema. Assim como o advogado prepara o caso para ser apresentado no Tribunal, também deverá preparar o caso para a negociação, a conciliação e a mediação, ressalvada a importante participação das partes, de forma cooperativa. Cf. Vezzulla, Mediação cit, p. 105. Sobre a pesrpectiva das partes em relação à mediação, que não necessariamente coincide com a perspectiva dos seus advogados, vide pesquisa empírica realizada por Nancy Welsh com base nas seguintes perguntas: $(i)$ What do individual disputants want and expect from the mediator and from the institutionalized mediation process itself? (ii) After the process hás concluded, what do these disputants perceive as value-added? (iii) What parts of the process or what mediators interventions raise particular concerns? WELSH, Stepping back through the looking glass cit., pp. 607-672.
} 
protagonistas do processo de solução de $\operatorname{conflitos}^{355}$. A presença das partes na sessão influi diretamente na percepção da justiça do processo e da justiça do resultado.

$\mathrm{Na}$ pesquisa empírica realizada neste trabalho foram analisados diferentes cenários nos programas de mediação e conciliação: i. ambas as partes representadas ou assistidas por seus advogados; ii. nenhuma parte assistida por advogado (auto-representação); iii. apenas uma das partes assistida por advogado; iv. ambas as partes presentes na sessão com seus advogados; v. advogados presentes na sessão sem as partes; vi. apenas um dos advogados e uma das partes presentes na sessão.

O que é mais comum, principalmente quando a mediação é incidental ao processo judicial, é que ambas as partes estejam assistidas por seus advogados ${ }^{356}$, embora eles possam ou não estar presentes na sessão de mediação/conciliação. Já nos setores préprocessuais e no programa de justiça comunitária pesquisados, a assistência e a presença do advogado não são exigidas e nem são normalmente observadas.

Em algumas situações admite-se que os advogados estejam presentes sem as partes (que estão disponíveis por telefone), desde que investidos de poderes para negociar. É o que ocorre nos casos envolvendo companhias de seguro, por exemplo, quando o valor da demanda não excede ao da cobertura contratual, o que foi observado nos programas pesquisados nos EUA.

Em São Paulo, no setor de conciliação processual em $1^{\mathrm{a}}$ e $2^{\mathrm{a}}$ instâncias, a presença do advogado na sessão é necessária, mesmo que desacompanhado das partes, pois, havendo acordo, há a extinção do processo. No setor de mediação de Santana, por outro lado, a presença de ambas as partes é obrigatória e recomenda-se a presença dos advogados apenas na pré-mediação, inclusive para informá-los que o mediador não fornece qualquer

\footnotetext{
355 Algumas pesquisas nos EUA revelam, por outro lado, a preferência dos advogados pela mediação avaliativa, selecionando mediadores com conhecimento técnico para entender os seus argumentos e o mérito do caso. Nestas mediações, os advogados tendem a dominar o processo e suplantar a voz das partes. Cf. MCADOO, WELSH, Look before you leap cit., p. 423 e WELSH, Stepping back through the looking glass cit., pp. 589-590.

${ }^{356}$ Nos programas pesquisados nos EUA, a auto-representação é mais comum em casos envolvendo direito de família, havendo um protagonismo maior dos advogados nas demandas cíveis.
} 
informação jurídica aos mediandos e não há a redação de eventual acordo na sessão. Essas tarefas são de competência do advogado, e realizadas fora da sessão.

No Centro de Mediação do Fórum Central do Rio de Janeiro, apenas no caso de ser obtido o acordo os advogados precisam ser consultados e o assinam juntamente com as partes. Contudo, determina a Resolução n ${ }^{0}$ 19/2009 que se uma das partes comparecer assistida por advogado, a outra, se quiser, poderá ter assistência judiciária prestada pela Defensoria Pública.

Em algumas entrevistas, principalmente em programas de mediação e não de conciliação, notou-se que a presença do advogado durante a sessão pode dificultar e inibir o protagonismo das partes na solução o conflito, cujas vozes são muitas vezes suplantadas pelas de seus advogados, com preocupações em relação aos honorários, cujas formas de cobrança nem sempre estão adaptadas aos meios autocompositivos de solução de conflitos. Durante a formulação e revisão do acordo, por outro lado, houve um forte reconhecimento nas entrevistas do papel e da presença fundamentais dos advogados.

Paralelamente, nas Associações dos Advogados tem ocorrido a criação de Comissões de Mediação e Arbitragem e de Meios Alternativos de Solução de Disputas, tanto no Brasil quanto nos EUA ${ }^{357}$.

Uma outra questão importante diz respeito à litigância repetitiva. Enquanto no Brasil os litigantes repetitivos nos programas de mediação e conciliação tendem a ser os mesmos litigantes repetitivos que atuam no Judiciário, nos EUA, onde o volume de casos é menor, o que chamou atenção foi o fato de serem os próprios mediadores e advogados os repeat players, percebendo-se, inclusive, que atuam conjuntamente em mediações privadas fora do Judiciário. Em alguns programas há controle a esse respeito (como em Maine), mas

\footnotetext{
${ }^{357}$ Reconhecendo oportunidades da advocacia na mediação, em 2009, o Prêmio Innovare, que visa identificar e disseminar práticas pioneiras e bem sucedidas da Justiça brasileira, concedeu prêmio à Seccional da Ordem dos Advogados do Brasil (OAB) do Rio de Janeiro, juntamente com a advogada fluminense Gabriela Asmar, por projeto vencedor na categoria Advocacia que visa à ampliação do campo de trabalho dos advogados, fazendo com que conheçam mais os demais métodos de resolução de conflitos, como a mediação e a arbitragem, e possam adequar a busca da resposta que dão a seu cliente a cada caso em concreto.
} 
o impedimento existe apenas para obstar que os mediadores atuem na esfera privada em mediações com as mesmas partes, por seis meses, e não impede relação repetitiva entre os mediadores e os advogados.

Em São Paulo, na Unidade Avançada de Atendimento (pré-processual), a grande maioria dos casos diz respeito a contratos bancários (cartão de crédito, financiamento, empréstimo) e renegociação de dívida, sob a iniciativa do devedor. Nos setores processuais $\left(1^{\mathrm{a}}\right.$ e $2^{\mathrm{a}}$ instancia) em São Paulo, também há litigância de massa, relacionada principalmente a prestadoras de serviço (água, luz, telefone), instituições financeiras e seguradoras, replicando o perfil das demandas que geram contencioso de massa e demandas repetitivas no Judiciário. Os demais programas pesquisados no Brasil não apresentaram litigância repetitiva, por serem programas muito recentes e com um menor volume de demandas.

O foco dos litigantes repetitivos tende a ser mais restrito, girando em torno do que aconteceria se as partes fossem ao Judiciário e quanto o réu estaria disposto a pagar e o autor a receber para evitar a demora, os riscos e os custos de um julgamento ${ }^{358}$. Esse foco se ajusta mais à conciliação do que à mediação, pois nesta última as relações continuadas precisam ser trabalhadas de forma mais ampla, não se voltando apenas ao acordo. Por outro lado, não se deve esquecer que a litigância repetitiva normalmente existe em apenas um dos pólos da demanda, e do outro lado pode estar um litigante para quem aquela talvez seja a única ação judicial já proposta. Este litigante não repetitivo também precisa ter voz no processo $^{359}$.

\footnotetext{
${ }^{358}$ Nesse sentido, Nancy Welsh e Leonard Riskin: The repeat players tend to focus narrowly on two questions: First, what would happen if the parties litigated the case? Second, how much is the defendant willing to pay and the plaintiff willing to accept to avoid the delay, risks, and costs of Trial? The lawyers and mediators then implement mediation procedures that they think will enable them to address those questions efficiently. Cf. RISKIN, Leonard; WELSH, Nancy. Is that all there is? The problem in Court-Oriented Mediation. George Mason Law Review, vol. 15, p. 866.

${ }^{359}$ Cf. Nancy Welsh e Leonard Riskin: As we emphasized, a person injured in an accident, terminated from a job, or sued for negligence is unlikely to experience the event as routine. The repeat players can see such matters as routine only through professional or occupational filters, which allow in only certain kinds of information and produce only certain kinds of outcomes through certain kinds of procedures. We hope that inviting the litigants themselves to reflect upon and influence the selection of the issues for discussion in their mediations will enable more one-shot players to get what they need in the procedures and outcomes of their cases. Our proposals may even produce and intriguing by-product-making these cases and the journey
} 
Em artigo acerca das perspectivas de advogados e clientes sobre os programas anexos às Cortes nos EUA, Deanne Siemer faz interessante sugestão para que os litigantes repetitivos, no caso, as entidades governamentais que tenham um número elevado de casos no Judiciário, apresentem uma política de participação em relação aos meios alternativos de solução de conflitos que esteja disponível para fins de acompanhamento e controle (inclusive em termos estatísticos) pelas Cortes ${ }^{360}$.

Notou-se também nos setores de mediação a realização de caucus (sessões individuais do mediador com cada parte), o que não se observou nos programas de conciliação, pesquisados no Brasil, que trabalham com um volume maior de casos e cujas sessões não chegam a durar mais do que 45 minutos, em média. Nos setores de mediação, como o do Fórum de Santana-SP e o do Fórum Central do Rio de Janeiro, que trabalham com casos de família, o caucus foi observado com mais frequência.

\section{b) Mediadores e Conciliadores}

Nos programas pesquisados nos EUA, os mediadores podem ser parte do quadro de funcionários da Corte (em tempo integral ou parcial), podem ser mediadores contratados para determinada sessão, mediadores privados, ou mesmo juízes (aposentados ou na ativa), embora quando na ativa o juiz mediador não seja o mesmo juiz que irá julgar a causa.

toward resolution come alive for at least some of the repeat players. As Marcel Proust wisely wrote: the real Voyage of discovery consists not in seeing new landscapes, but in having new eyes. Ibidem, p. 932. Sobre a litigância repetitiva, Marc Galanter contrapõe os repeat players aos one shot players. Segundo este autor, o repeat player leva vantagem em litigância de massa e não sofre significativas perdas com o desfecho desfavorável das demandas em que se vê envolvido, possuindo recursos para perseguir seus interesses a longo prazo. Cf. GALANTER, Marc. Why the 'Haves' come out ahead: speculations on the limits of legal change. Law and Society Review, vol. 9, n. 2, 1975, p. 4.

${ }^{360}$ Nas palavras do autor: each governmental entity that has significant numbers of civil cases on the court's docket should provide the court with its policy on participation in ADR procedures. These policy statements should be available for inspection in the clerk's Office. If statistics indicate that government cases respond less well to ADR than might be expected, it is important to explore with the responsible public officials the possible cause of this pattern. SIEMER, Deanne. Perspective of Advocates and Clients on Court-Sponsored ADR. In: SANDER, Frank (Org.). Emerging ADR Issues in State and Federal Courts, American Bar Association, 1991, p. 187. 
A regra geral é que a mediação seja atividade remunerada nos programas norteamericanos, e a forma, fonte e valor dependem da relação de trabalho que os mediadores mantêm com as Cortes. Quando atuam como autônomos, costumam receber por hora ou sessão realizada. Há normalmente a formação de fundos nos Tribunais Estaduais, compostos por taxas judiciárias pagas pelas partes e por destinação orçamentária do Tribunal, e alguns contam inclusive com verba federal para investimentos em projetospiloto, manutenção dos programas voltados aos meios alternativos de solução de conflitos e pagamento dos mediadores.

Esta é uma importante diferença em relação aos programas de mediação/ conciliação no Brasil, onde até então a regra geral é que os mediadores exerçam atividade voluntária e não remunerada, o que gera maior rotatividade no quadro de mediadores/conciliadores dos programas, e dificulta o processo de profissionalização ${ }^{361}$.

Em todos os programas pesquisados, no Brasil e nos EUA, o conciliador/mediador não precisa ser advogado ${ }^{362}$, podendo ser psicólogo, assistente social, engenheiro, biólogo, policial, dentre outros. Nos setores processuais de conciliação no Brasil, contudo, muitos conciliadores são advogados que estão prestando concurso público, pois esta atividade conta como tempo de exercício da advocacia para fins do concurso ${ }^{363}$.

Os mediadores devem passar por treinamentos e capacitações, e em alguns programas de mediação (como na Flórida) há um processo de certificação sujeito à renovação a cada dois anos. No Brasil, a Resolução $n^{\circ} 125$ do CNJ buscou criar uma uniformização quanto ao número de horas e tipos de treinamento e aperfeiçoamento

\footnotetext{
361 Tal como exposto acima, no item 5.1 referente à regulamentação legislativa e judiciária sobre a mediação no Brasil, a remuneração do mediador é reconhecida como uma meta a ser alcançada, mas depende de lei que disponha a seu respeito. De acordo com a Resolução no 125 do CNJ, de 29/11/2010, caberá aos Núcleos permanentes de Métodos Consensuais de Solução de Conflitos regulamentar, se for o caso, a remuneração dos conciliadores e mediadores, nos termos da legislação específica.

362 A única exceção nos programas pesquisados é o de Connecticut, onde na Superior Court o mediador é o juiz. Há um debate no Brasil sobre a necessidade de os mediadores serem advogados: de acordo com o Projeto de Lei de Mediação, os mediadores judiciais devem ser advogados, sujeitos à fiscalização da OAB, enquanto o Projeto de novo Código de Processo Civil não manteve esta exigência.

363 Vide art. 58 da Resolução 75/2009 e Enunciado Administrativo no 3 do Conselho Nacional de Justiça.
} 
exigidos (o conteúdo programático e carga horária mínimos foram estabelecidos pelo CNJ no anexo desta resolução).

Outra diferença entre os programas de mediação pesquisados nos EUA e no Brasil é quanto à escolha dos mediadores, que tende a ser feita de forma consensual pelas partes nos EUA, podendo escolher mediadores que estejam fora de eventual lista disponibilizada pela Corte, havendo a designação de mediador pelo juiz apenas se não houver consenso. Nos programas pesquisados no Brasil, com exceção do Programa de Justiça Comunitária, os conciliadores e mediadores atuam normalmente em rodízio, uma vez por semana, em escala definida pelo setor, que distribui os casos entre os mediadores sem que esta seja uma escolha realizada pelas partes.

Um ponto importante diz respeito às regras estabelecidas sobre ética, responsabilidades e conflitos de interesse dos mediadores nos programas de mediação pesquisados, que orientem a fiscalização de suas atividades e cuja infração possa justificar inclusive a exclusão da lista/quadro dos mediadores.

Nos programas pesquisados nos EUA, estas regras são estabelecidas pelo Tribunal em códigos de conduta, regras sobre certificação de mediadores, dentre outros instrumentos normativos. Nos programas pesquisados no Brasil alguns provimentos e resoluções trazem estas regras, aplicando-se em São Paulo aos mediadores as mesmas hipóteses de impedimento e suspeição previstas em lei para os juízes e auxiliares da justiça. A resolução $\mathrm{n}^{\mathrm{o}} 125$ do CNJ, acima referida, trouxe um Código de Ética em seu anexo, estabelecido pelo Conselho Nacional de Justiça.

Havendo desnível de poder entre as partes, reconheceu-se em todos os programas que é atribuição do conciliador/mediador lidar com este fato e orientar as partes em situações de desequilíbrio de poder, como nos casos de auto-representação, casos envolvendo violência, intimidação, abuso, interesses de menores, dentre outros. 
Os conciliadores e mediadores são novos atores sociais na administração do sistema de justiça, estando entre os juízes e as partes e seus advogados. Por isso, é importante que haja no Tribunal o reconhecimento dos serviços prestados, o que influi também na criação de uma identidade profissional, estabelecimento de remuneração adequada e de incentivos para a qualificação do corpo de mediadores/conciliadores. Estes foram os desafios para a criação de uma carreira profissional presentes também em relação aos conciliadores dos Juizados $^{364}$.

Apesar de serem imparciais, há quem considere os mediadores mais próximos dos juízes do que dos advogados ${ }^{365}$. O risco é que a mediação se aproxime e seja cooptada pelo processo judicial, já tendo recebido denominações que revelam esta aproximação e fazem alusão à litigância - "litimediation", "litigization" ou "litigotiation".

Urska Velikonja analisou o mercado de mediação nas últimas três décadas nos EUA, e constatou que o crescimento do número de mediadores não foi acompanhado pelo número de oportunidades de trabalho nesta área. As causas disso para a autora seriam: $\mathbf{i}$. como a mediação não é uma profissão regulamentada, há poucas barreiras para se entrar no mercado, que admite profissionais de variadas áreas (normalmente apenas um curso de capacitação habilita o interessado a entrar no mercado, e estes cursos tem se tornado cada vez mais frequentes nos EUA); ii. há uma estrutura piramidal em que somente poucos mediadores ganham muito e muitos mediadores ganham pouco (winner-takes-allmarket $)^{366}$.

\footnotetext{
${ }^{364}$ Nas palavras de um conciliador: "se o Juizado pudesse trabalhar a figura do conciliador de uma outra forma. Até que se preparasse o conciliador em nível de concurso, que fossem mini-juízes. Como por exemplo, na justiça do trabalho existem os juízes classistas. É uma pessoa qualquer, alguém que o sindicato indica, mas quando ele está sentado ali como juiz classista há o respeito por eles (...). O juiz classista tem para nós o mesmo poder, a mesma influência. Lá na conciliação (Juizado) não. Tem até alguns advogados que dizem: não vou perder meu tempo sendo conciliador. Vai lá quem não tem o que fazer (...). Se houvesse uma escola, um curso, ou o dia-a-dia mesmo que você vai progredindo naquela carreira, por números de pontos em conciliação, por uma atuação, tudo é um incentivo. Poderia até ser válido: uma carreira progressiva dentro da conciliação". Cf. FAISTING, O dilema da Dupla Institucionalização cit., p. 55.

${ }^{365}$ Are the Mediators judging adjuncts? Este questionamento é enfrentado em WELSH, Nancy. The place of Court-connected mediation in a Democratic Justice System. 5 Cardozo Journal of Conflict Resolution, 2004, pp. 136-137.

366 VELIKONJA, Urska. Making peace and making money: economic analysis of the market for mediators in private practice. Albany Law Review, vol. 72, 2009, pp. 258-259.
} 
Os mediadores privados normalmente recebem seus casos de escritórios de advocacia ou das Cortes, realizando a mediação sob a sombra do processo judicial ${ }^{367}$. Segundo Velikonja, tirando a pequena parcela de mediadores que atuam na área comercial e fazem fortunas ${ }^{368}$, a maioria dos mediadores não consegue viver apenas da mediação, em tempo integral.

Nos Estados em que há programas de mediação anexos às Cortes, o mercado é mais receptivo à mediação, pois as Cortes contratam mediadores ou mesmo remetem os casos à mediação privada. Esta é geralmente a principal fonte de renda do mediador, ainda que os valores pagos não sejam tão elevados ${ }^{369}$. Por outro lado, trabalhar como voluntário nos primeiros anos, em centros comunitários, continua sendo uma das boas formas de se adquirir experiência prática e fazer contatos com profissionais nesta área ${ }^{370}$.

Segundo essa mesma autora, os mediadores, por mais que atuem como terceiros imparciais e facilitadores do diálogo entre as partes, tendem a se especializar em diferentes áreas, como família, disputas envolvendo políticas públicas, meio ambiente, e mediações comerciais e podem trabalhar em vários segmentos: centros de mediação comunitária, programas do governo, empresas, associações, programas de mediação anexos às Cortes e em mediação privada ${ }^{371}$.

No Brasil, a criação do FONAME - Fórum Nacional de Mediação, em 13.12.2007, composto por entidades, associações, juízes, mediadores e acadêmicos que se dedicam ao

\footnotetext{
367 Os consumidores de mediação tendem a comparar os custos da mediação com os custos da demanda judicial, e não com os custos de diferentes mediações. Os novos mediadores não competem, portanto, pelo preço oferecido pelos seus serviços. Ibidem, p. 290.

${ }^{368} \mathrm{Na}$ área comercial, os mediadores recebem seus casos e clientes mais dos advogados do que das Cortes, e se não tiverem uma boa rede de relacionamento seus nomes não constarão de lista restrita de mediadores selecionados para disputas comerciais. Muitos mediadores que atuam na área comercial são juízes aposentados. No JAMS, por exemplo, um dos maiores centros privados de solução de conflitos nos Estados Unidos, há uma média de 250 mediadores, dentre os quais mais de 50\% são juízes aposentados. Ibidem, pp. 274 e 282.

${ }^{369}$ Ibidem, p. 259.

${ }^{370}$ Ibidem, p. 265.

${ }^{371}$ Ibidem, p. 261 e 264.
} 
aperfeiçoamento, à divulgação e à prática da mediação de conflitos foi um importante marco rumo ao reconhecimento da mediação e da atividade do mediador ${ }^{372}$.

\section{c) Juiz e Juízo}

O juiz é quem direciona geralmente o conflito à mediação, realizando a triagem caso a caso, preferencialmente no início da demanda. Em alguns programas (como no programa de mediação da Superior Court de Connecticut), o juiz, aposentado ou na ativa, pode ser mediador, mas não será o mesmo juiz que julgará o caso.

Quando não é o mediador, o juiz não tem envolvimento durante a sessão de mediação. Apenas toma conhecimento da realização do acordo e de seus aspectos formais, resguardada a confidencialidade acerca do caso.

Nos EUA, o acordo obtido entre as partes não necessariamente é homologado juiz. Apenas em alguns casos as partes podem requerer esta homologação judicial (judicial order), havendo a possibilidade de uma revisão dos termos do acordo pelo Juiz, como nos casos em que há interesses de menores de idade.

Já no Brasil é mais comum os acordos obtidos serem reduzidos a termo e homologados pelo Juiz coordenador ou Juiz da Vara, o que ocorre inclusive nos setores pré-processuais de conciliação, com a homologação do acordo obtido extrajudicialmente. Esta possibilidade está prevista no Código de Processo Civil (CPC, art. 475-N, III e V).

\footnotetext{
${ }^{372}$ O FONAME tem por objetivos: difundir a cultura da paz; promover a contínua troca de ideias e o intercâmbio de experiências entre profissionais e estudiosos da mediação e de outros meios de solução pacífica de conflitos; formular e definir critérios ou indicadores destinados a constituir parâmetros, mínimos e/ou ótimos, a serem observados na capacitação, na formação e na sensibilização para meios de solução pacífica de conflitos, na qualificação de profissionais em meios de solução pacífica de conflitos, na orientação quanto a preceitos e procedimentos éticos, a serem observados por profissionais, voluntários, servidores e estudiosos devotados à promoção de meios de solução pacífica de conflitos; promover eventos que se ocupem dos meios de solução pacífica de conflitos; opinar sobre proposituras legislativas e contribuir para a produção normativa sobre meios de solução pacífica de conflitos. Vide mais detalhes em http://foname.blogspot.com/2007/11/blogue-do-foname.html. Acesso em 20/12/2010.
} 
Enquanto nos programas pesquisados nos EUA os juízes revelam preferência pela mediação, com vistas à redução do volume de demandas e do custo da demora, chegandose a afirmar que os juízes passaram a fazer parte $d o A D R l o b b y^{373}$, no Brasil ainda há resistência de muitos juízes à utilização dos meios alternativos de solução de conflitos no Judiciário.

Conforme destaca Kazuo Watanabe, há a falsa percepção de que a função de conciliar seria atividade menos nobre do que a de sentenciar, não percebendo muitos juízes que a função jurisdicional consiste basicamente em pacificar com justiça os conflitantes, o que pode ocorrer através de meios autocompositivos. Trata-se da cultura da sentença, a ser substituída pela cultura da pacificação ${ }^{374}$.

Daí a importância que os treinamentos e capacitações também sejam feitos pelos juízes, a fim de melhor se familiarizarem com as técnicas autocompositivas, em um processo de sensibilização, inclusive para a realização das triagens e encaminhamentos de casos aos setores de mediação/conciliação. É o que prevê a mencionada Resolução n ${ }^{\circ} 125$ do $\mathrm{CNJ}$, ao determinar que nas Escolas da Magistratura haja módulo voltado aos métodos consensuais de solução de conflitos, no curso de iniciação funcional e no curso de aperfeiçoamento $^{375}$.

As conciliações têm sido incentivadas pelo Conselho Nacional de Justiça (como através das Semanas de Conciliação) sob um argumento de aumento de produtividade, redução do volume de demandas e alcance das metas estabelecidas aos Tribunais. O desafio, contudo, é conciliar quantidade e qualidade, pois quando a conciliação é aplicada a um volume grande de casos (contencioso de massa e litigantes repetitivos), a qualidade dos acordos e do processo tende a ser afetada.

\footnotetext{
${ }^{373}$ RESNIK, For Owen cit., p. 193.

${ }^{374}$ WATANABE, Cultura da sentença cit., pp. 686-687.

375 Esta resolução também determina que cabe ao CNJ providenciar que as atividades relacionadas à conciliação, mediação e outros métodos consensuais de solução de conflitos sejam consideradas nas promoções e remoções de magistrados pelo critério de merecimento.
} 
Nos setores de conciliação e mediação, além da figura do juiz coordenador há o Diretor ou Coordenador do setor, normalmente servidor do Tribunal, que algumas vezes também atua como mediador/conciliador. O Diretor tem um papel muito importante, guardando normalmente uma memória das atividades do setor. As entrevistas da pesquisa empírica foram feitas com estes Diretores, que atuam ao lado do juiz coordenador.

Em alguns casos o setor de conciliação funciona como Unidade Administrativa ou Cartório Judicial, possuindo uma estrutura de funcionários e servidores próprios. As atribuições do diretor ou coordenador do setor estão relacionadas à organização de diversas atividades, agendamento e realização de audiências, organização da pauta, fiscalização dos serviços, organização administrativa e de pessoal, dentre outras.

Nos EUA, com exceção do Estado de Connecticut, todos os programas de mediação pesquisados possuem um Administrador/Diretor que atua no Escritório Central, normalmente localizado na Suprema Corte do Estado, e que pode ser contratado como autônomo ou ser funcionário da Corte. Dentre as atribuições deste Diretor, estão o gerenciamento e monitoramento dos programas de mediação no Estado, disponibilização de treinamentos e avaliação dos mediadores, divulgação de processos e regras sobre mediação, dando suporte administrativo e tirando dúvidas sobre o procedimento de mediação em geral. A sua formação varia em cada programa. Não precisa ser advogado, mas, conforme as entrevistas realizadas, é aconselhável que tenha experiência em mediação.

Os escritórios centrais têm um papel relevante no funcionamento dos programas de mediação, sendo uma ponte de contato entre as partes, juízes, mediadores e advogados, dentre outras variadas atribuições que podem assumir.

Com a criação dos programas de mediação/conciliação nos Tribunais, Waine Brazil destaca a necessidade de um planejamento para introduzir e explicar os novos mecanismos autocompositivos de solução de conflitos aos operadores e usuários, preferencialmente através de apresentações orais e face a face, no âmbito das escolas de direito, escritório de advocacia, associações de advogados, junto aos litigantes institucionais, dentre outros, com 
o objetivo de esclarecer os objetivos, as vantagens e desvantagens destes mecanismos. Isso deve se somar à existência de um sistema centralizado para tirar dúvidas e dar maiores informações sobre os programas, por telefone ou pessoalmente, assim como o fornecimento de uma lista com breve descrição dos programas de solução de conflitos oferecidos pelo Tribunal a todos aqueles que ingressam com uma demanda judicial ${ }^{376}$.

\subsection{Limites dos meios alternativos de solução de conflitos}

O objetivo deste item final é analisar os limites dos meios alternativos de solução de conflitos, especialmente da mediação, através de um olhar externo sobre o papel da mediação e sua relação com o sistema de justiça e um olhar interno sobre a forma e técnicas de atuação na mediação. Parte-se da premissa de que a análise destes limites e críticas não diminui o papel da mediação como um mecanismo adequado de solução de conflitos, daí porque não se levanta os riscos com o objetivo de refutá-los. O objetivo é considerar a mediação ao lado de outras formas de solução de conflitos, com o mesmo status, sendo uma das portas possíveis para se resolver o litígio entre as partes.

Assim, há casos que não devem ser levados à mediação e aos meios autocompositivos de solução de conflitos, e seriam mais bem resolvidos pelo Judiciário, da mesma forma em que há casos que seriam mais bem resolvidos fora do ambiente adversarial do processo judicial.

As críticas externas são consideradas a partir do que defende Owen Fiss, que representa uma importante voz na doutrina norte-americana sobre os limites dos meios alternativos de solução de conflitos. Em dois artigos, sobre "As formas de justiça" 377 e

\footnotetext{
${ }^{376}$ Cf. BRAZIL, Institutionalizing ADR cit., 1991, pp. 76-77

${ }^{377}$ FISS, As formas de justiça cit., pp. 25-104.
} 
"Contra o acordo",378, este autor revela seus principais argumentos, que envolvem, no limite, considerações sobre o papel do Judiciário.

Para Fiss, a função do Judiciário não é solucionar controvérsias, mas dar um significado adequado aos valores públicos e reorganizar instituições a partir do desempenho desta função. A Constituição do país identifica os valores (liberdade, igualdade, devido processo legal, direito de propriedade, dentre outros) e o Judiciário lhes atribui um significado específico e concreto no contexto do conflito, através da adjudicação ${ }^{379}$.

A reforma estrutural, assim, seria um tipo de adjudicação especial, que reconhece o caráter burocrático do Estado moderno e a afetação da nossa vida social pela operação de organizações de grande porte. O juiz, nestes casos, teria o papel de reestruturar organizações para eliminar a ameaça imposta aos valores constitucionais pelos arranjos institucionais existentes. A reforma estrutural tem suas raízes nos anos 50 e 60, marcados por um ativismo judicial e pela presidência da Suprema Corte por Earl Warren, e em especial pelas decisões no caso Brown vs. Board of Education, que buscaram reconstruir a realidade social e reestruturar o sistema de educação pública ao banir o sistema de segregação racial das escolas, resguardando o valor de igualdade racial ${ }^{380}$.

Dois aspectos da atividade judicial justificariam a assunção pelo Judiciário (e não pelo Legislativo ou Executivo) deste papel de dar significado aos valores constitucionais: a obrigação do juiz de participar de um diálogo processual e a sua independência e imparcialidade ${ }^{381}$.

Fiss escreve no âmbito da adjudicação constitucional, cujo foco não é direcionado a incidentes entre particulares, mas ao papel que as organizações de grande porte desempenham na determinação das condições da vida social. Sua concepção de adjudicação

\footnotetext{
${ }^{378}$ FISS, Contra o Acordo. In: SALLES, Carlos Alberto de. (Org.) Um novo Processo Civil: estudos norteamericanos sobre jurisdição, constituição e sociedade. Coord. de tradução Carlos Alberto de Salles. São Paulo: Revista dos Tribunais, 2004, pp. 121-145. No original: FISS, Owen. Against settlement, Yale Law Journal, vol. 93, 1984.

${ }^{379}$ FISS, As formas de justiça cit, p. 26.

${ }^{380}$ Ibidem, pp. 27-28.

${ }^{381}$ Ibidem, p. 42.
} 
parte de cima - da função do juiz - para baixo. Ele se contrapõe ao que é sustentado por autores como Donald Horowitz (The Courts and Social Policy) e Lon Fuller (The forms and limits of adjudication), que consideram a solução de controvérsias uma das mais importantes funções das Cortes. Nas palavras de Fiss:

\begin{abstract}
Não estou certo de que a solução de controvérsias é uma descrição adequada da função social das Cortes. Na minha concepção, as Cortes existem para dar significado aos valores públicos, não para solucionar controvérsias. A Adjudicação constitucional é a manifestação mais intensa dessa função, mas isso também parece verdade no que se refere à maioria dos casos cíveis e criminais da atualidade e, talvez, da maior parte da história ${ }^{382}$.
\end{abstract}

Segundo Fiss, a visão da adjudicação voltada à solução de conflitos entre dois vizinhos e o movimento favorável ao acordo e aos meios autocompositivos de soluções de conflitos baseiam-se em premissas questionáveis e pressupõem uma igualdade entre as partes litigantes nem sempre existente.

Não acredito que o acordo, como prática genérica, seja preferível ao julgamento ou deva ser institucionalizado em uma base extensa e ilimitada. Deveria ser tratado, ao contrário, como uma técnica altamente problemática para a simplificação dos dockets. (...) Assim como a transação penal, o acordo é uma rendição às condições da sociedade de massa e não deveria ser encorajado ou valorizado ${ }^{383}$

O desequilíbrio de poder e disparidade de recursos entre as partes podem influenciar o acordo de várias formas: a parte mais pobre pode ter menos possibilidades de reunir e analisar as informações necessárias à previsão da decisão do litígio pelo Judiciário, e a falta de recursos pode influenciar na qualidade de apresentação de sua pretensão; pode necessitar, de imediato, da indenização que pleiteia e ser induzida à celebração de um acordo como forma de acelerar o pagamento, mesmo que ciente de que este valor é inferior ao que conseguiria no Judiciário; e, ainda, a parte com menos recursos pode ser forçada a celebrar um acordo por não possuir os recursos necessários ao financiamento do processo judicial (honorários advocatícios, custos, etc.). Isso tudo sem a figura do juiz para diminuir o impacto das desigualdades distributivas. ${ }^{384}$

\footnotetext{
${ }^{382}$ Ibidem, p. 65.

${ }^{383}$ FISS, Contra o Acordo cit, pp. 123-124.

384 Ibidem, pp. 125-126. Sobre o desnível de poder, também se manifestam Sander e Rozdeiczer: Disproportionate power may be the result of various differences between the parties, such as financial
} 
Além do desequilíbrio de poder, há ainda o risco de ausência de consentimento legítimo das partes e a falta de base para o envolvimento judicial continuado, pois o acordo põe fim ao processo, desconsiderando que o envolvimento da Corte tende a continuar após o julgamento, com o cumprimento e efetivação da decisão, sendo a ação judicial apenas uma fase da contínua batalha entre as partes, cuja sentença não põe fim, mas modifica seus termos e equilíbrio de poderes ${ }^{385}$.

Segundo Fiss, o objetivo da adjudicação deve ser entendido de forma mais ampla, não restrito à solução privada de controvérsias. O trabalho dos juízes, agentes públicos, não é maximizar os objetivos de particulares nem simplesmente assegurar a paz, mas explicar e conferir força aos valores contidos em textos de grande autoridade, como a Constituição e as Leis, para interpretá-los e deles aproximar a realidade. Essa tarefa não seria desempenhada quando as partes celebram um acordo ${ }^{386}$.

Para Fiss, ser contra o acordo é "sugerir que quando as partes celebram um acordo a sociedade obtém menos do que parece, por um preço que não sabe que está pagando. As partes podem compor-se amigavelmente sem que a justiça seja feita. $\mathrm{O}$ acordo celebrado em um processo judicial que tenha por objeto a dessegregação escolar poderia assegurar a paz e, contudo, deixar de garantir a igualdade racial" 387.

Sobre as críticas de Fiss, Judith Resnik aponta para o fato de que este autor não leva em conta os problemas cotidianos que vão para o Judiciário, mas apenas aqueles institucionalmente relacionados a reformas estruturais. Segundo Resnik, poucos

resources, legal arguments and representation, negotiation skills, emotional dependence, etc. Depending on the source of power, the parties may have different strengths in different forums. Knowing her sources of power, the weaker party should strategically select a forum where her powers are relatively strongest. (...) If the party knows that her case is strong on law, and that in negotiation she would be intimidated by powerful and sophisticated lawyers on the other side, she may prefer to go to court with a lawyer instead of engaging in face-to-face negotiation or mediation. Moreover, as many mediators do not believe that power balancing is a part of their role, a weaker party (particularly an unrepresented party) may be better protected in court than in mediation. SANDER, ROZDEICZER, Matching cases cit., pp. 30-31.

${ }^{385}$ FISS, Contra o Acordo cit., pp. 134-135.

${ }^{386}$ Ibidem, p. 139.

${ }^{387}$ Ibidem, p. 140. 
acadêmicos olham o ato de julgar como uma profissão e um serviço social repleto de questões mundanas e não apenas questões exóticas. ${ }^{388}$

Nesse sentido, Marines Suares ressalta o risco de a mediação afastar do sistema judicial os problemas cotidianos, fazendo com que os precedentes e a jurisprudência não sejam diretamente influenciados pelo que ocorre no ambiente comunitário ${ }^{389}$.

Fiss entende que a diferença entre ele e os defensores dos meios alternativos de solução de conflitos não está no tipo de conflito considerado (objeto da demanda), ora voltado à solução de conflitos individuais, ora à promoção de reforma estrutural, estes últimos dominando a pauta de um sistema judiciário moderno. Dessa forma, não seria possível separar os casos em duas direções, uma voltada ao acordo e outra ao julgamento, criando critérios para a sua separação prospectiva. Segundo Fiss, o que o separa dos partidários dos meios alternativos de solução de conflitos não é o fato de estarem preocupados com distintos universos de casos; a separação seria mais profunda, advindo de entendimentos diversos sobre os propósitos do processo judicial e de seu lugar na sociedade. É uma diferença de pontos de vista sobre o papel da adjudicação, em termos de função institucional, de ideais e valores ${ }^{390}$.

As críticas internas aos meios autocompositivos, por sua vez, são aqui consideradas a partir da perspectiva de Trina Grillo ${ }^{391}$, que aponta os riscos em relação à mediação obrigatória nos Tribunais em seu artigo que leva o seguinte título: "A Alternativa da

\footnotetext{
${ }^{388}$ No original: (...) neither Fiss nor many others focused on the dreariness of much of adjudication - on its dailiness, its ordinariness. Little academic writing attends to judging as a job and as a social service replete with a host of mundane problems rather than a feast o exotica RESNIK, For Owen cit., p. 197.

${ }^{389}$ SUARES, Mediación: conducción de disputas cit., p. 54.

${ }^{390}$ FISS, Contra o Acordo cit., pp. 143-144.

391 As críticas são sistematizadas por Bush e Folger sob o rótulo "The Oppression Story", que pode ser contada sobre a mediação através de um viés crítico, estando dentre os seus seguidores, além de Trina Grillo, Richard Abel (1982), Christine Harrington (1985), Richard Delgado (1985), dentre outros. Segundo estes críticos, a mediação seria um perigoso instrumento de aumento de poder estatal sobre os indivíduos, e do poder dos mais fortes sobre os mais fracos, em um ambiente de informalidade e consenso. Sob a justificativa de acesso à justiça, os conflitos ingressam em um ambiente em que as regras processuais e materiais não estão claras e o desnível de poder entre as partes pode gerar coerção e manipulação do mais fraco pelo mais forte, com acordos e resultados injustos. Cf. BUSH, Robert Baruch, FOLGER, Joseph. The promise of mediation cit., pp. 15-17.
} 
Mediação: processo perigoso para mulheres" ${ }^{392}$, voltado especificamente para os casos de direito de família e de mediação obrigatória, não obstante muitos dos riscos que aponte possam também existir em outras áreas e em mediações voluntárias.

O perigo da mediação estaria em determinar, muitas vezes de forma velada e subliminar, como as partes devem se expressar e tomar decisões, comportamentos que de forma não explícita podem impedir as partes de falarem com a sua voz autêntica. Nesse caso, as mulheres, que teriam uma maior preocupação com o aspecto relacional do que os homens, sairiam em desvantagem ${ }^{393}$. Trina Grillo é mediadora na Califórnia (onde a mediação é obrigatória em alguns casos envolvendo direito de família), e ressalta que muito embora esteja escrevendo sobre os perigos da mediação, com base em sua experiência e nos relatos de pessoas que participaram de sessões de mediação, ser mediadora é um dos ofícios que mais gosta de fazer e no qual acredita. Suas críticas teriam por trás um olhar construtivo.

Grillo analisa as normas não escritas do sistema microlegal que está presente no processo de mediação. Embora informais, possuem um componente normativo e estão acompanhadas de sanções que, a priori, podem parecer triviais (como um riso do mediador, a crítica ao pai ou à mãe por não colocar o interesse dos filhos em primeiro lugar, a instrução sobre não falar sobre o passado, buscar um culpado ou agir de forma apenas emocional), mas que teriam efeitos perigosos. No caso de divórcio e litígios envolvendo questões familiares, as partes estariam ainda mais vulneráveis a essas regras e sanções no ambiente da mediação ${ }^{394}$.

Tal como já comentado, o processo de mediação possui uma forma, havendo um mínimo de devido processo legal a ser garantido, relacionado à voluntariedade das partes (autonomia da vontade), à imparcialidade do mediador e às oportunidades que têm as partes de dialogar sobre o caso (contraditório). Trina Grillo não fala exatamente destas garantias,

\footnotetext{
${ }^{392}$ GRILLO, Trina. The mediation alternative: process dangers for women. Yale Law Journal, vol. 100, April, 1991, pp. 1545-1610.

${ }^{393}$ Ibidem, p. 1550.

${ }^{394}$ Ibidem, p. 1556.
} 
mas sim de regras veladas e subliminares que podem também existir. É natural que as partes busquem perceber e se adequar aos objetivos e ao tipo de ambiente criado em uma sessão de mediação, fazendo uma leitura do cenário em que se encontram. Isso influi na maneira pela qual articulam os seus problemas e se expressam durante a sessão.

Trina Grillo considera que há algumas proposições comumente aceitas e aplicadas na mediação, e muitas vezes não se tem a consciência de seus riscos. Evitar que a fala das partes seja baseada em culpa, focar no futuro e não no passado das relações, tratar as partes como se estivessem em um mesmo plano de igualdade, dar espaço para que questões emocionais e sentimentos sejam expressos, mas desencorajar manifestações de raiva são alguns exemplos de regras que, mesmo não escritas, rotulam bons e maus comportamentos das partes ${ }^{395}$. As sanções são na maior parte das vezes informais.

Em uma relação em que a esposa sofre abuso do marido, a tendência é que a mulher transpareça menos calma e tranquilidade do que o homem, e que a raiva ou histerismo que apresente sejam interpretados como algo negativo. Isso poderia também ocorrer no processo judicial, mas em um ambiente informal como o da mediação, no qual não há juízo de valor e atribuição de culpa às partes, o marido se encontraria em uma posição mais forte $^{396}$.

Normalmente a mediação é contraposta à adjudicação por não se basear em regras legais gerais (right based approach) e abrir a possibilidade de se considerar o contexto e os interesses das partes (interested based approach) na solução do conflito, indo além da polarização entre o certo e errado, ganhador e perdedor, e buscando uma solução que melhor atenda a ambas as partes (win-win). Evita-se falar em culpa e na regra fria da lei, para se levar em conta as responsabilidades que surgem no contexto específico, com foco na relação continuada das partes. Segundo Trina Grillo, o risco para a mediação está em se abandonar as regras gerais e o contexto e interesses específicos não serem efetivamente considerados. Ficar-se-ia com o pior dos dois mundos ${ }^{397}$.

\footnotetext{
395 Ibidem, pp. 1559-1573.

${ }^{396}$ Ibidem, p. 1584.

${ }^{397}$ Ibidem, p. 1558.
} 
As críticas de Trina Grillo recaem especialmente sobre a mediação obrigatória no Judiciário, pois neste caso as partes não fazem suas escolhas livremente, quer quanto à forma e momento de submeter o conflito à mediação, quer quanto à participação do advogado e a escolha do terceiro que irá mediar o conflito ${ }^{398}$.

Os mediadores não são juízes e por isso não se manifestam sobre o conflito. Entretanto, assim como os juízes, devem ser imparciais, apesar de estarem mais próximos das partes, ajudando-as a entenderem e apresentarem suas demandas. Estão menos distantes das partes do que o Juiz, nas Cortes, e muito embora os riscos de parcialidade, preconceitos e projeção de seus próprios conflitos e valores sejam os mesmos que um juiz poderia apresentar, na mediação estes riscos são exacerbados, em um ambiente informal no qual os controles são reduzidos ${ }^{399}$. Nos locais em que os mediadores são autorizados a fazer recomendações às Cortes, na ausência de acordo entre as partes ${ }^{400}$, esta relação de poder é ainda mais perigosa.

Quanto à presença dos advogados, Grillo cita que na Califórnia eles são normalmente excluídos das sessões de mediação em casos envolvendo direito de família, para que as partes falem com suas próprias vozes. Porém, para avaliar se esta exclusão contribui ao empoderamento das partes, seria necessário considerar quais são as razões pelas quais se contrata advogado. No caso de uma mulher que busca o divórcio, por exemplo, o advogado seria normalmente contratado pela sua expertise na proteção dos direitos da cliente e por promover uma camada de proteção (layer of insulation) na intermediação entre a cliente e o seu marido: a expressão "não me ligue, ligue para o meu advogado" pode ser uma forma muito eficaz de empoderamento. Segundo a autora, nenhuma destas razões desapareceria no contexto de mediação ${ }^{401}$.

\footnotetext{
${ }^{398}$ Ibidem, pp. 1581-1582.

${ }^{399}$ Ibidem, p. 1589.

${ }^{400}$ De acordo com o Código Civil da Califórnia, seção 4607(e), if no agreement is reached in mediation, a mediator may, consistent with local court rules, render a recommendation to the court based on information acquired during the mediation.

${ }^{401}$ Ibidem, p. 1597.
} 
Ainda que os riscos de uma mediação obrigatória possam afetar homens e mulheres, Grillo defende que eles podem ser ainda mais perigosos para as mulheres. A autora cita um estudo que comparou as razões daqueles que aceitam ou rejeitam a oportunidade de mediação e concluiu que $44 \%$ das razões apresentadas pelas mulheres que rejeitam a mediação estão ligadas ao medo ou vontade de evitar seu ex-marido, enquanto que os homens que rejeitam a mediação o fazem normalmente porque são céticos sobre o processo de mediação ou estão convencidos de que podem ganhar a causa no Judiciário. A mediação obrigatória e a necessidade de as partes se encontrarem pessoalmente, sem a presença dos advogados, é vista como mais perigosa para as mulheres do que para os homens. Análises feministas apresentam razões para isso, com base na maior propensão das mulheres em se preocuparem com o aspecto relacional, baseado em uma ética do cuidado, na conexão com o outro e no contexto relacional (ethic of care), enquanto que os homens estariam mais preocupados com uma ética da justiça, com ênfase no individualismo, utilização de regras para resolver dilemas morais e igualdade (ethic of justice). Isso teria consequências na mediação. $^{402}$

Mesmo que alguns defendam a mediação obrigatória como uma oportunidade àqueles que não têm muitas informações sobre o processo de conhecerem e aderirem voluntariamente à mediação, essa não parece ser uma razão suficiente para a mediação ser obrigatória nas Cortes, pois há outras formas de se familiarizar as partes com a mediação, como disponibilizando vídeos ou programas de orientação sobre a mediação, além de outras medidas com fins educativos. A escolha legislativa de tornar a mediação obrigatória, para Trina Grillo, tem sido um erro. E, mais, segundo esta autora, a mediação pode se tornar um lobo em pele de cordeiro, pois muito embora se revista de um discurso de empoderamento das partes e volte-se contra os problemas da litigância adversarial, traz em si problemas e perigos camuflados e que podem afetar as partes. ${ }^{403}$

\footnotetext{
${ }^{402}$ Ibidem, pp. 1601-1602.

${ }^{403}$ Ibidem, pp. 1608-1610.
} 


\section{CONCLUSÕES}

O desafio deste trabalho foi analisar quais são as condições que devem ser buscadas para que haja uma boa relação entre a mediação e o processo judicial, ou seja, para a institucionalização da mediação no âmbito do Judiciário.

A partir das hipóteses formuladas inicialmente, relacionadas à identidade processual e funcional que a mediação deve resguardar no ambiente judicial, conclui-se que:

1. Uma boa interação entre a mediação e o processo judicial depende de que a mediação não seja vista apenas como um contraponto ao processo judicial ou uma alternativa à morosidade e ao sistema adversarial, mas sim considerada a partir de suas bases constitutivas, levando em conta os predicados e valores que lhe são próprios, em especial o seu devido processo legal mínimo.

2. Além da identidade processual, a mediação precisa ter resguardada a sua identidade funcional junto ao Judiciário: o desenho institucional e os objetivos dos programas, as escolhas realizadas (mediação obrigatória ou voluntária, pré-processual ou processual), a triagem dos conflitos, o procedimento adotado e os papéis assumidos pelos atores envolvidos precisam estar claramente definidos, pois influem na boa relação entre a mediação e o processo judicial.

3. A institucionalização da mediação no Judiciário é positiva quando vista como uma das formas possíveis de incentivo e suporte à mediação, sem, porém, excluir outras portas de acesso à mediação não atreladas a mecanismos judiciais e estatais.

Observou-se que a institucionalização da mediação tem forte relação com a regulação do seu processo. As escolhas sobre o desenho dos programas de mediação e os papéis assumidos pelos atores envolvidos são questões que repercutem na percepção da justiça do processo e no sucesso da institucionalização da mediação. 
Nesta relação entre processo judicial e mediação, é muito importante evitar polarizações que possam levar à distinção entre justiça de $1^{\mathrm{a}}$ e $2^{\mathrm{a}}$ classes. Notou-se na pesquisa que um dos principais riscos da institucionalização da mediação é que ela seja considerada uma second best solution, sendo vista como uma forma de contenção dos litígios que chegam ao Judiciário, que deveria se dedicar apenas aos casos "mais importantes". Ao se criar esta porta de acesso aos meios autocompositivos, portanto, é preciso ter o cuidado de que ela não seja uma porta lateral ou secundária de acesso à justiça, mas sim um filtro que direcione os conflitos à solução e pacificação social.

O processo judicial e a mediação possuem sintaxes diferentes, a começar pelo fato de que se está comparando uma técnica heterocompositiva, com a participação adversarial das partes e a presença direta do Estado (jurisdição estatal) a outra autocompositiva, com a participação consensual da partes e a presença indireta do Estado (no caso de a mediação ser realizada no ambiente judicial).

O devido processo legal é frequentemente tratado em relação às técnicas heterocompositivas, como nos processos judiciais e arbitrais, sendo uma garantia de contenção do exercício de poder e autoridade, quer das partes, quer de terceiro. Conclui-se neste trabalho, contudo, que há também devido processo legal nos meios autocompositivos, a ser colocado em termos mínimos para não gerar uma procedimentalização ou formalização excessiva que vá de encontro à autonomia e flexibilidade do desenho processual da mediação. Estes contornos mínimos são dados pela norma constitucional (garantias processuais), e fazem com que as formas autocompositivas possam ser tratadas à luz da teoria geral do processo.

Viu-se que na mediação é o processo que costuma se adequar ao conflito, e não o conflito ao processo (regra geral de "one size does not fit all"). Entretanto, conforme destacado neste trabalho, a existência de flexibilidade não equivale à inexistência de forma e à ausência de relações de poder na mediação, havendo garantias mínimas a serem resguardadas - minimal but meaningful due process standards ${ }^{404}$.

\footnotetext{
${ }^{404}$ Expressão utilizada por REUBEN, Constitutional Gravity: a Unitary Theory cit, pp. 952-954.
} 
Diferentemente de um negócio jurídico e transação que ocorrem fora do Judiciário, e cujo acordo pode ser homologado pelo juiz sem a preocupação com o procedimento que o gerou, quando a mediação e a conciliação são realizadas em um ambiente institucional, público como o judicial ou mesmo privado como o das Câmaras de Conciliação e Arbitragem, o procedimento é regulado e visa a promover uma garantia de previsibilidade e segurança àqueles que participam da mediação. No caso das Câmaras, há o relevante papel dos regulamentos e dos termos contratuais em que as partes estabelecem as regras procedimentais; no caso da mediação e conciliação realizadas incidentalmente ao processo judicial, cujos conflitos são encaminhados pelo juiz, há o papel dos provimentos e regulações no âmbito do Judiciário. Nestes ambientes institucionais, tanto o resultado como o procedimento importam, sendo o mediador responsável pela condução e resguardo deste último.

Assim, notou-se que a busca das partes por satisfação se dá não apenas em relação aos resultados da demanda, mas também em relação ao processo pelo qual eles são gerados. Trata-se da distinção entre a justiça do processo e a justiça do resultado, que envolve diferentes níveis de percepção e satisfação das partes.

Sendo a institucionalização da mediação no Judiciário o objeto central deste trabalho, foram enfrentadas as diferentes razões que justificam esta institucionalização e também os riscos que podem advir da mesma.

As partes recorrem ao Judiciário e ao processo judicial com frequência. Conforme os dados do relatório do $3^{\circ}$ trimestre de 2010 do Índice de Confiança na Justiça (ICJBrasil), há uma má avaliação do Judiciário como prestador de serviços públicos, mas embora o Judiciário seja considerado lento, caro e de difícil utilização, a maioria dos entrevistados declarou que certamente procuraria o Judiciário para resolver eventuais conflitos. $41 \%$ dos entrevistados declaram que já entraram com algum processo ou ação na Justiça ${ }^{405}$.

${ }^{405}$ Relatório ICJBrasil cit., p.15. 
De acordo com a PNAD 2009, por sua vez, das 12,6 milhões de pessoas com 18 anos ou mais de idade que estiveram em situação de conflito, 92,7\% (11,7 milhões) buscaram solução, sendo que $\mathbf{5 7 , 8 \%}$ das pessoas recorreram à Justiça comum e $\mathbf{1 2 , 4 \%}$ ao Juizado Especial. Aqueles que não buscaram solução na Justiça para o conflito que tiveram $\mathbf{( 2 9 , 8 \%}$ ou 3,8 milhões de pessoas) apontaram alguns motivos. Dentre eles, destacaram-se o fato de a solução do problema ter ocorrido por meio de mediação ou conciliação (em 27,6\% dos casos) e a percepção de que demoraria muito resolver o conflito no Judiciário (em $15,9 \%$ dos casos) ${ }^{406}$.

Tendo o Judiciário como um aliado institucional, o que permite que se obtenha a confiança das partes em relação à mediação e o suporte do Judiciário aos programas e centros que funcionam junto às Cortes, esta parceria não deve ser considerada como um fim em si mesma, pois a mediação precisa em algum momento sair da sombra do Judiciário e conquistar o seu próprio espaço.

Neste trabalho realizou-se pesquisa empírica em diferentes programas de mediação para analisar na prática como a institucionalização da mediação vem ocorrendo no Judiciário. Após serem estudadas as medidas implementadas para a regulação e incentivo dos meios alternativos de solução de conflitos, foi realizada pesquisa e visita a programas de mediação nos EUA e no Brasil, em diferentes Estados, cujos resultados estão sistematizados e expostos nos quadros comparativos elaborados nesta tese.

A pesquisa empírica foi realizada nos anos de 2009 (nos EUA ${ }^{407}$ ) e 2010 (no Brasil $^{408}$ ), tendo como objeto o desenho e o funcionamento dos programas de mediação e conciliação no Judiciário. Tratou-se de uma pesquisa de diagnóstico, que pautou suas escolhas na diversidade de elementos comparativos - diferentes níveis de regulação, centralização, modelos, volumes de casos, dentre outros. Não se objetivou a indicação de um melhor programa, nem a mera transposição de experiências entre países, pois não há um

\footnotetext{
406 Vide essas e outras informações no relatório disponível em http://www.ibge.gov.br/home/estatistica/populacao/vitimizacao_acesso_justica_2009/default.shtm. Acesso em 20/12/2010.

${ }^{407}$ Em programas de mediação nos Estados de Ohio, Maine, Flórida e Connecticut.

${ }^{408}$ Em programas de mediação e conciliação nos Estados de São Paulo, Rio de Janeiro e no Distrito Federal
} 
modelo padrão a ser seguido e o desenho de cada programa depende do contexto em que está inserido. Mesmo entre os programas de um mesmo Estado foram observadas diferenças, de forma que o objetivo desta pesquisa foi comparar para melhor conhecer, contrastar experiências nacionais e estrangeiras para que sobressaia a identidade de cada programa e sistema.

Percebe-se que o ponto de partida rumo à institucionalização da mediação já foi dado pelo Judiciário, que assumiu papel de protagonista no apoio à mediação como medida de solução de conflitos e de administração da Justiça. Esta foi uma premissa da pesquisa. Os caminhos, todavia, não estão definitivamente traçados, e um dos objetivos deste trabalho, por meio do estudo empírico de experiências e práticas já realizadas no Brasil e nos EUA, foi contribuir para os passos ainda por serem dados.

Tal como reconhecido pela Resolução $n^{\circ} 125$ do CNJ, de 29/11/2010, o papel do Judiciário não é mais apenas fornecer solução adjudicada mediante sentenças dos juízes, mas também dar outras respostas ao jurisdicionado, como através dos mecanismos de resolução consensual de controvérsias. São duas pautas distintas da justiça contemporânea: a justiça formal da decisão e a justiça informal da mediação e conciliação, e o Judiciário tem transitado entre ambas, além garantir o controle da justiça informal por meio da homologação dos acordos.

Nesse sentido, o bom funcionamento do Judiciário é essencial para que outros métodos de solução de conflitos se desenvolvam positivamente. Um não deve ser pensado para corrigir as insuficiências do outro, devendo haver uma relação de cooperação que leve a um círculo virtuoso e não vicioso entre os diferentes métodos de solução de conflitos.

O discurso de combate à morosidade processual pela mediação e outros meios alternativos ao Judiciário não pode perder de vista que quando se abre uma nova porta aos conflitos, esta porta não é apenas de saída (via acordos que extinguem o processo), mas também de entrada de novos conflitos (litigiosidade contida), que podem ganhar 
visibilidade e gerar o acesso de novas demandas ao Judiciário, sem que isso seja interpretado como algo necessariamente negativo.

Observou-se que a triagem dos conflitos é um momento sensível na institucionalização dos programas, pois nem todos os casos são adequados para a mediação, e uma boa seleção é essencial para que as partes confiem no processo e, consequentemente, nos resultados obtidos. O desafio é indicar os critérios a serem adotados nesta triagem, escolher quem os define e quando devem ser aplicados. O último capítulo desta tese analisou como esta triagem vem ocorrendo, de acordo com os dados da pesquisa empírica, e outras possibilidades de como poderia vir a ocorrer.

Não há atualmente uma objetivação ou normatização de critérios para a triagem dos conflitos que vão à mediação. Quem a realiza (seja o juiz, as partes ou seus advogados) define e utiliza os seus próprios critérios, de acordo com as circunstâncias do caso concreto. A escolha de critérios para identificar os casos que melhor se ajustem à mediação passa também pela análise de quais são os objetivos do programa, quais são os serviços oferecidos por ele e por outros programas disponíveis no Judiciário.

No percurso deste trabalho, foram analisados também os limites que existem em relação aos meios autocompositivos e à sua institucionalização no Judiciário, ponderandose, ainda, que nenhuma mudança legislativa ou institucional em favor da mediação será possível se não estiver acompanhada de mudanças culturais, de comportamento e de mentalidade.

Conclui-se, assim, que a institucionalização da mediação não é um fim em si mesma e que apenas assegurará o acesso à justiça (do processo e do resultado) quando vier acompanhada de outras mudanças. Para que a criação de setores de conciliação e mediação no Judiciário produza resultados é necessário que as partes, os advogados, os mediadores, juízes e juízo se prepararem para a autocomposição, com a profissionalização e capacitação do terceiro, o estabelecimento de remuneração adequada, a abertura dos advogados e das partes ao diálogo, assim como a realização criteriosa da triagem dos conflitos. Estas 
mudanças são essenciais para que os avanços legais e institucionais tornem-se efetivos, sem o risco de se criar apenas uma etapa procedimental e formal que mais afaste do que aproxime as partes da pacificação do conflito. 


\section{REFERÊNCIAS}

ABREVAYA, Sergio Fernando. Evaluación del sistema de mediación prejudicial. La Trama: Revista Interdisciplinaria de mediación y resolución de conflictos, Ciudad Autónoma de Buenos Aires, dez. 2007, pp.1-22.

ACKERMAN, Robert M. The September 11th Victim Compensation Fund: An Effective Administrative Response to a National Tragedy, Harvard Negotiation Law Review, vol. 10, 2005, pp. 135-229.

ALEXANDER, Nadja. Mediation in practice: common law and civil law perspectives compared. International Trade and Business Law, vol. 6, 2001, pp. 1-18.

ALFINI, James et al. What happens when mediation is institutionalized? To the parties, practioners, and host institutions. Ohio St. J. on Dispute Resolution, vol. 9, 1993-1994, pp. 307-332.

ALVES, Rafael Francisco. O devido processo legal na arbitragem. In: JOBIM, Eduardo; MACHADO, Rafael Bicca (Coord.). Arbitragem no Brasil: aspectos relevantes. São Paulo: Quartier Latin, 2008, pp. 381-416.

ANDRADE, Carlos Drummond. A Paz entre os Juízes. In: Esquecer para Lembrar: Boitempo III. Rio de Janeiro: Sabiá, 1979.

ARTERTON, Janet Bond. Alternative Dispute Resolution in the District Court of Connecticut. In: MAZADOORIAN, Harry N. (Org). Mediation Practice Book: critical tools, techniques and forms. Law First Publishing and Quinnipiac University School of Law, 2002.

BARBOSA MOREIRA, José Carlos. Privatização do Processo? In: Temas de Direito Processual Civil - sétima série, São Paulo: Saraiva, 2001.

. Saneamento do processo e audiência preliminar. Revista de Processo, n. 40, out./dez. 1985.

BEDAQUE, José Roberto dos Santos. Efetividade do Processo e Técnica processual. São Paulo: Malheiros, 2006.

BENETI, Sidnei Agostinho. Da conduta do juiz. São Paulo: Saraiva, 2003.

BINGHAM, Lisa B. Why suppose? Let's find out: a public policy research program on dispute resolution, Journal of Dispute Resolution, 2002, pp. 101-126.

BRAGA NETO, Adolfo; SAMPAIO, Lia Regina Castaldi. O que é mediação de conflitos. São Paulo: Brasiliense, 2007. 
BRAGA NETO, Adolfo. Reflexões sobre a Conciliação e a Mediação de Conflitos. In: SALLES, Carlos Alberto de (Org.). As grandes transformações do processo civil brasileiro: homenagem ao professor Kazuo Watanabe. São Paulo: Quartier Latin, 2009, pp. 488-506.

BRASIL. Ministério da Justiça. Secretaria de Reforma do Judiciário. Acesso à Justiça por Sistemas Alternativos de Administração de Conflitos: mapeamento nacional de programas públicos e não governamentais. Brasília: 2005. Disponível em http://portal.mj.gov.br/. Acesso em 20/12/2010.

BRASIL. Ministério da Justiça. Secretaria de Reforma do Judiciário. Manual de Mediação Judicial. AZEVEDO, Andre Gomma de (Org.). Brasília: 2009. Disponível em www.mj.gov.br. Acesso em 20/12/2010.

BRASIL. Conselho Nacional de Justiça. Relatório Justiça em Números. Brasília: CNJ, 2009. Disponível em www.cnj.jus.br. Acesso em 20/12/2010.

BRAZIL, Wayne D. Continuing the conversation about the current status and the future of ADR: a view from the Courts. Journal of Dispute Resolution, vol. 11, 2000, p. 11-39.

For Judges: suggestions about what to say about ADR at case management conferences and how to respond to concerns or objections raised by counsel. Ohio St. J. on Disp. Resol., vol. 16, 2000, pp. 165-193.

. Hosting mediations as a representative of the system of civil justice. Ohio St. J. on Disp. Resol., vol. 22, 2007, pp. 227-275.

Comparing Structures for the delivery of ADR services by Courts: Critical values and concerns. Ohio St. J. on Disp. Resol., vol. 14, 1999, pp.715-811.

. Court ADR 25 years after Pound: have we found a better way? Ohio St. J. on Disp. Resol., vol. 18, 2002, pp. 93-149.

. A judge's perspective on lawyering and ADR. Alternatives to High Cost Litig., vol. 19, 2001, pp. 44-47.

. Institutionalizing ADR programs in Courts. In: SANDER, Frank E. A. Emerging ADR Issues in State and Federal Courts, American Bar Association, 1991.

BROWN, Gina Viola. A Community of Court ADR programs: how court-based ADR programs help each other survive and thrive. The Justice System Journal, vol. 26, n. 3, 2005.

BUSH, Robert Baruch; FOLGER, Joseph. The promise of mediation: the transformative approach to conflict. San Francisco: Jossey Bass, 2005. 
BÜLOW, Oskar Von. La teoría de las excepciones procesales y los presupuestos procesales, Tradução Miguel Angel Rosas Lichtschein, Buenos Aires: EJEA Ediciones Jurídica, 1964.

CALAMANDREI, Piero. Il concetto di 'lite' nel pensiero di Francesco Carnelutti. Rivista di Diritto Processuale Civile, 1928, parte prima.

CAPPELlETTI, Mauro; GARTH, Bryant. Acesso à Justiça, Tradução Ellen Gracie Northfleet, Porto Alegre: Fabris, 1988.

CAPPELLETI, Mauro. O processo civil no direito comparado. Tradução Hiltomar Martins Oliveira. Belo Horizonte: Cultura Jurídica - Ed. Líder, 2001.

Problemas de Reforma do Processo nas Sociedades Contemporâneas, Revista Forense, n. 318, abr./jun. 1992, pp. 119-128.

Os métodos alternativos de solução de conflitos no quadro do movimento universal de acesso à justiça. Revista de Processo, n. 74, abr-jun. 1994, pp. 82-97.

CARMONA, Carlos Alberto. Arbitragem e Processo: um comentário à Lei 9307/96. $3^{\mathrm{a}}$ edição. São Paulo: Atlas, 2009.

CARNELUTTI, Francesco. Lite e funzione processuale. Rivista di Diritto Processuale Civile, 1928, parte prima.

CINTRA, Antônio Carlos de Araújo; GRINOVER, Ada Pellegrini; DINAMARCO, Cândido Rangel. Teoria Geral do Processo. São Paulo: Malheiros Editores, 2005.

COBB, Sara; RIFKIN, Janet. Practice and Paradox: deconstructing neutrality in Mediation. Law \& Society Inquiry, vol. 16, 1991, 35-62.

COOLEY, John W. A advocacia na mediação. Tradução René Loncan. Brasília: Editora Universidade de Brasília, 2001.

COSTA, Alexandre Araújo. Cartografia dos métodos de composição de conflitos. In: AZEVEDO, André Gomma de (Org.). Estudos em Arbitragem, Mediação e Negociação, v. 3, Brasília: Grupos de Pesquisa, 2004.

COVER, Robert M.; FISS, Owen M. (Orgs). The structure of procedure. Mineola: The Foundation Press, 1979.

CUNHA, Luciana Gross. Juizado Especial: criação, instalação, funcionamento e a democratização do acesso à justiça. São Paulo: Saraiva, 2008.

CUNHA, Luciana Gross (Coord.). Relatório ICJBrasil, 3 o trimestre de 2010, $2^{\mathrm{a}}$ onda, Ano 2 ,

Disponível

em 
http://www.direitogv.com.br/Default.aspx?PagId=DKHFMLQM\&navid=1262. Acesso em 20/12/2010.

CUNHA, Luciana Gross; ALMEIDA, Frederico de. Justiça e Desenvolvimento Econômico na Reforma do Judiciário Brasileiro. Trabalho apresentado no evento sobre Direito e Desenvolvimento: um diálogo entre os BRICs, promovido pela Direito GV, Universidade de Wisconsin e ABDI, São Paulo, nov. 2010.

CUNHA, Luciana Gross; GABBAY, Daniela Monteiro (Coord.). Diagnóstico sobre as causas de aumento das demandas judiciais cíveis, mapeamento das demandas repetitivas e propositura de soluções pré-processuais, processuais e gerenciais à morosidade da justiça. Departamento de Pesquisas Judiciárias - Conselho Nacional de Justiça. Brasília: 2010. Aguardando publicação.

DANZIG, Richard; LOWY, Michael J. Everyday Disputes and Mediation in the United States: a reply to Professor Felstiner. Law and Society Review, vol. 9, 1975, pp. 675-694.

DEBRUN, Michel. A conciliação e outras estratégias. São Paulo: Editora Brasiliense, 1983.

DEMARCHI, Juliana. Mediação: proposta de implementação no processo civil brasileiro. Tese (Doutorado em Direito Processual) - Faculdade de Direito da Universidade de São Paulo (FDUSP), São Paulo, 2007.

DINAMARCO, Cândido Rangel. A instrumentalidade do processo. São Paulo: Malheiros, 2008.

Litisconsórcio. São Paulo: Malheiros, 2009.

. A Reforma da reforma. $5^{\text {a }}$ ed. São Paulo: Malheiros, 2003.

. O processo no Juizado das Pequenas Causas. In: WATANABE, Kazuo (Org.). Juizado especial de pequenas causas: Lei 7.244, de 7 de novembro de 1984. São Paulo: Revista dos Tribunais, 1985.

Fundamentos do processo civil moderno, v. 1. São Paulo: Malheiros, 2010.

EBENER, Patrícia A. et al. In the eye of the beholder: Tort litigants' evaluations of their experiences in the civil justice system, Law and Society Review, vol. 24, 1990, pp. 953-986.

FACHADA, Pedro; FIGUEIREDO, Luiz Fernando; LUNDBERG, Eduardo. Sistema Judicial e Mercado de Crédito no Brasil. In: Nota Técnica $n^{o} 35$ do Banco Central, mai. 2003.

FAISTING, Andre Luiz. O dilema da Dupla Institucionalização do Poder Judiciário: o caso do Juizado Especial de Pequenas Causas. In: SADEK, Maria Tereza (Org.). O sistema de justiça. São Paulo: IDESP: Sumaré, 1999. 
FARIA, José Eduardo. Direitos Fundamentais e Jurisdição: o Judiciário após a globalização. Direito em debate, Ijuí, Rio Grande do Sul, ano 6, n. 9, jan./jun. 1997.

. O direito na economia globalizada. São Paulo: Malheiros, 2002.

FELSTINER, William; ABEL, Richard L.; SARAT, Austin. The emergence and transformation of disputes: naming, blaming, claiming, Law and society review, vol. 15, $\mathrm{n}$. 3-4, 1980-81, pp. 631-654.

FERRAZ, Leslie Sherida. A conciliação nos Juizados Especiais Cíveis: uma análise empírica. In: SALLES, Carlos Alberto de (Org.). As grandes transformações do processo civil brasileiro: homenagem ao professor Kazuo Watanabe. São Paulo: Quartier Latin, 2009, pp. 393-416.

FISHER, Roger; URY, William; PATTON, Bruce. Getting to Yes: negotiating agreement without giving in. United States: Pinguin Books, 1991.

FISS, Owen. The Bureaucratization of the Judiciary. Yale Law Journal, vol. 92, n. 8, jul. 1983, pp. 1442-1468.

Contra o Acordo. In: SALLES, Carlos Alberto de. (Org.) Um novo Processo Civil: estudos norte-americanos sobre jurisdição, constituição e sociedade. Coord. de tradução Carlos Alberto de Salles. São Paulo: Revista dos Tribunais, 2004.

As formas de Justiça. In: SALLES, Carlos Alberto de (Org). Um novo Processo Civil: estudos norte-americanos sobre jurisdição, constituição e sociedade. Coord. de tradução Carlos Alberto de Salles. São Paulo: Revista dos Tribunais, 2004.

FLORY, Thomas. El juez de paz y el jurado en el Brasil imperial, 1808-1871: Control social y estabilidad política en el nuevo Estado. Traducción de Mariluz Caso, México: Fondo de Cultura Econômica, 1986.

FOLEY, Glaucia Falsarella. Justiça Comunitária: por uma justiça de emancipação. Belo Horizonte; Editora Fórum, 2010.

FOLGER, Joseph P.; BUSH, Robert A. Baruch. Transformative mediation and Third-Party Intervention: ten hallmarks of a transformative approach to practice. Mediation Quarterly., vol. 13, 1996, pp. 264-267.

FREITAS JR., Antonio Rodrigues de. Conflitos de Justiça e limites da mediação para a difusão da cultura da paz. In: SALLES, Carlos A (Org). As Grandes Transformações do Processo Civil Brasileiro. Homenagem ao Prof. Kazuo Watanabe. São Paulo: Quartier Latin, 2009, pp. 509-534

FULLER, Lon L. The forms and limits of adjudication. Harvard Law Review, vol. 92, 1978-1979. 
Mediation - its forms and functions. S. Cal. L. Rev., vol. 44, 1971.

GABBAY, Daniela Monteiro. Pedido e Causa de Pedir. São Paulo: Saraiva, 2010.

GABBAY, Daniela Monteiro; ALVES, Rafael Francisco; LEMES, Selma Ferreira. Projeto de pesquisa: Arbitragem e Poder Judiciário. Parceria Institucional Acadêmico-Científica da Escola de Direito de São Paulo da Fundação Getulio Vargas (DIREITO GV) e do Comitê Brasileiro de Arbitragem (CBAR). Revista Brasileira de Arbitragem, v. 19, 2008, pp. 7-23.

GAJARDONI, Fernando da Fonseca; ROMANO, Michel Betenjane; LUCHIARI, Valeria Ferioli Lagrasta. $O$ gerenciamento do processo. In: GRINOVER, Ada Pellegrini; WATANABE, Kazuo; LAGRASTA NETO, Caetano (Org.). Mediação e gerenciamento do processo: revolução na prestação jurisdicional e guia prático para a instalação do setor de conciliação e mediação. São Paulo: Atlas, 2008, pp. 18-34.

GALANTER, Marc. The Hundred-Year Decline of Trials and the Thirty Years War. Stanford Law Review Symposium, vol. 57, 2005.

Reading the Landscape of Disputes: what we know and don't know (and think we know) about our allegedly contentious and litigious society. UCLA Law Review, vol. 31, 1983-1984.

vol. 81, 2002.

The turn against law: the recoil against expanding accountability. Texas Law Rev., A world without trials? Journal of Dispute Resolution, 2006, pp. 7-33

. The vanishing Trial: what the numbers tell us, what they may mean. Dispute Resolution Magazine, vol. 4, Summer 2004.

Compared to what? Assessing the quality of Dispute Processing. Denver University Law Review, v. 66, 1989, pp. xi-xiv.

. Why the 'Haves' come out ahead: speculations on the limits of legal change. Law and Society Review, vol. 9, n. 2, 1975.

. Adjudication, Litigation, and related phenomena. In: LIPSON, Leon e WHEELER, Stanton. Law and the social sciences. New York: Russel Sage Foundation, 1986, pp. 152257.

GOLDBERG, Stephen; SANDER, Frank; ROGERS, Nancy; COLE, Sarah. Dispute resolution: negotiation, mediation and other processes. 4th ed, New York: Aspen Publishers, 2003.

GOLDING, Martin P. Dispute Settling and Justice. In: COVER, Robert M. e FISS, Owen M. (Orgs). The structure of procedure. Mineola: The Foundation Press, 1979. 
GRILLO, Trina. The mediation alternative: process dangers for women. Yale Law Journal, vol. 100, 1991, pp. 1545-1610.

GRINOVER, Ada Pellegrini; WATANABE, Kazuo; LAGRASTA NETO, Caetano (Org.). Mediação e gerenciamento do processo: revolução na prestação jurisdicional e guia prático para a instalação do setor de conciliação e mediação. São Paulo: Atlas, 2008.

GRINOVER, Ada Pellegrini. As garantias constitucionais do direito de ação. São Paulo: Revista dos Tribunais, 1973.

. Conciliação e Juizados de Pequenas Causas. In: WATANABE, Kazuo (Org.). Juizado especial de pequenas causas: Lei 7.244, de 7 de novembro de 1984. São Paulo: Revista dos Tribunais, 1985.

A conciliação extrajudicial no quadro participativo. In: GRINOVER, Ada Pellegrini; DINAMARCO, Candido Rangel; WATANABE, Kazuo (Org.). Participação $e$ Processo. São Paulo, Revista dos Tribunais, 1988.

HADDAD, Eneida Gonçalves de Macedo; SINHORETTO, Jacqueline; PIETROCOLLA, Luci Gati. Justiça e Segurança na periferia de São Paulo: os centros de integração da cidadania. São Paulo: IBCCRIM, 2003.

HARRINGTON, Christine B.; MERRY, Sally Engle, Ideological Production: The Making of Community Mediation, Law \& Soc'y Rev, vol. 22, 1988, pp. 714-23.

HARRINGTON, Christine B. Shadow justice: the ideology and institutionalization of alternatives to Court. CT: Greenwood Press, 1985.

HAZARD JR., Geoffrey C.; TARUFFO, Michele. American Civil Procedure: an introduction. New Haven and London: Yale University press, 1993.

HEDEEN, Timothy; COY, Patrick G. Community mediation and the court system: the ties that bind. Mediation Quarterly, vol. 17, n. 4, 2000, pp. 351-367

HEISE, Michael. Justice Delayed? An empirical analysis of civil case disposition time. Case Western Reserve L. Rev., vol. 51, 2000.

HENSLER, Deborah R. Suppose it's not true: challenging mediation ideology, Journal of Dispute Resolution, 2002, pp. 85-93.

Science in the Court: Is there a role for Alternative Dispute Resolution? Law and Contemporary Problems, vol. 54, n. 3, 1991, pp. 171-193.

KAGAN, Robert A. Adversarial legalism: the American way of law. Cambridge: Harvard University Press, 2003. 
LEAL, Victor Nunes. Coronelismo, enxada e voto: $O$ município e o regime representativo no Brasil. São Paulo: Alfa Omega, 1986.

LEDERACH, John Paul. Enredos, pleitos y problemas: Una guía práctica para ayudar a resolver conflictos. Guatemala: Ediciones Clara-Semilla, 1992.

LIEBMAN, Enrico Tullio. O despacho saneador e o julgamento do mérito. Revista dos Tribunais, vol. 767, ano 88, set/1999.

. Eficácia e Autoridade da Sentença e outros escritos sobre a Coisa Julgada. Tradução Alfredo Buzaid e Benvindo Aires, tradução de textos posteriores à edição de 1945 por Ada Pellegrini Grinover. 4a edição. Rio de Janeiro: Forense, 2006.

. Manual de Direito Processual Civil. vol. I, $3^{\text {a }}$ edição. Tradução e notas Cândido Rangel Dinamarco. São Paulo: Malheiros, 2005.

LOPES, Levindo Ferreira. Manual dos juizes de paz. Ouro Preto: Silva Cabral, 1892.

LORENCINI, Marco Antônio Garcia Lopes. A contribuição dos meios alternativos para a solução das controvérsias. In: SALLES, Carlos A (Org). As Grandes Transformações do Processo Civil Brasileiro. Homenagem ao Prof. Kazuo Watanabe. São Paulo: Quartier Latin, 2009, pp. 599-626.

Manual de Teorias Básicas de Análisis y Resolución de Conflictos. Produzido no Sexto ICAR/OEA Taller de Verano: La investigación Acadêmica y La Práctica de La Resolución de Conflictos Sociales: ampliando el campo, 8-21 de junio de 2008, Arlington, VA.

MATHER, Lynn. Yngvesson. Language, audience, and the transformation of disputes. Law and Society Review, vol. 15, n. 3-4, 1980-1981, pp. 775-821.

MCADOO, Bobbi; WELSH, Nancy A; WISSLER, Roselle. Institutionalization: What do empirical studies tell us about Court Mediation? Dispute Resolution Magazine, vol. 9, 2003.

MENDONÇA, José Xavier Carvalho de. Tratado theorico e pratico das justiças de paz. Rio de Janeiro: Garnier, 1889.

MENKEL-MEADOW, Carrie J; LOVE, Lela Porter; SCHNEIDER, Andrea Kupfer; STERNLIGHT; Jean R. Dispute resolution: beyond the adversarial model. New York: Aspen Publishers, 2005.

MENKEL-MEADOW, Carrie J. Pursuing settlement in an adversary culture: a tale of innovation co-opted or "the law of ADR". Fla. St. U. L. Rev., vol. 19, 1991-1992, pp. 1-46.

Introduction: What Will We Do When Adjudication Ends? A Brief Intellectual History of ADR,UCLA L. Rev., vol. 44, 1997, pp. 1613-1625 
MIRANDA, Pontes de. Tratado da ação rescisória: das sentenças e de outras decisões. $5^{\mathrm{a}}$ ed. Rio de Janeiro: Forense, 1976.

MNOOKIN, Robert H.; KORNHAUSER, Lewis. Bargaining in the shadow of the law: the case of divorce, Yale Law. Journal, vol. 88, 1979.

MOORE, Christopher W. O processo de Mediação: estratégias práticas para a resolução de conflitos. Tradução Magda França Lopes. Porto Alegre: Artmed, 1998.

NATÓ, Alejandro Marcelo; QUEREJAZU, Maria Gabriela Rodriguez; CARBAJAL, Liliana Maria. Mediación Comunitária: conflitos en el escenario social urbano. Buenos Aires: Universidad, 2006.

NETO, Caetano Lagrasta. Juizado Especial de Pequenas Causas e Direito Processual Civil Comparado. In: WATANABE, Kazuo (Org.). Juizado especial de pequenas causas: Lei 7.244, de 7 de novembro de 1984. São Paulo: Revista dos Tribunais, 1985.

NIEMIC, Robert; STIENSTRA, Donna; RAVITZ, Randall E. Guide to judicial management of cases in ADR. Federal Judicial Center, 2001, pp. 128-135

PINHEIRO, Armando Castelar; CABRAL, Célia. O mercado de crédito no Brasil: o papel do judiciário e de outras instutuições. Ensaios BNDES, n. 9, 1998. Disponível em www.bndes.gov.br. Acesso em 20/12/2010.

PINHO, Humberto Dalla Bernardina de. A mediação e a necessidade de sua sistematização no processo civil brasileiro. Disponível em http://www.humbertodalla.pro.br/index.htm. Acesso em 20/12/2010.

PRESS, Sharon. Institutionalization: Savior or Saboteur of Mediation? Florida State University Law Review, vol. 24, 1997, pp. 902-917.

QUEIROZ, Maria Isaura Pereira de. O Mandonismo local na vida política brasileira e outros ensaios. São Paulo: Alfa Omega, 1976.

RESNIK, Judith. Many doors? Closing doors? Alternative dispute resolution and adjudication. Ohio State Journal on Dispute resolution, vol. 10, 1995.

. Mediating preferences: litigant preferences for process and judicial preferences for settlement. Journal of dispute resolution, 2002, p. 155-169.

For Owen M. Fiss: some reflections on the triumph and the death of adjudication. University of Miami Law Review, vol. 58, 2003, p. 173-200.

. Whither or Whether adjudication. Yale Law School, Public Law Working Paper No. 135, disponível em http://papers.ssrn.com/abstract=978806. Aceso em 20/12/2010. 
REUBEN, Richard. Constitutional Gravity: a Unitary Theory of Alternative Dispute Resolution and Public Civil Justice, UCLA L. Rev., vol. 47, pp. 952-1104.

RISKIN, Leonard L. Understanding mediators' orientations, strategies, and techniques: a grid for the perplexed. Harvard Negotiation Law Review, vol. 7, 1996, pp. 1-51.

RISKIN, Leonard L.; WELSH, Nancy. Is that all there is? The problem in Court-Oriented Mediation. George Mason Law Review, vol. 15, pp. 863-932.

SADEK, Maria Tereza Aina (Org). O sistema de Justiça. São Paulo: IDESP: Sumaré, 1999. . Juizados Especiais: Um novo paradigma. In: SALLES, Carlos Alberto de (Org.). As grandes transformações do processo civil brasileiro: homenagem ao professor Kazuo Watanabe. São Paulo: Quartier Latin, 2009, pp. 418-430.

SALLES, Carlos A. A arbitragem na solução de controvérsias contratuais da Administração Pública. Tese apresentada à Faculdade de Direito da Universidade de São Paulo como requisito para obtenção do título de Livre-Docente junto ao Departamento de Direito Processual, São Paulo, 2010.

Mecanismos Alternativos de Solução de Controvérsias e Acesso à Justiça: a inafastabilidade da tutela jurisdicional recolocada. In: FUX, Luiz; NERY JR, Nelson, WAMBIER, Teresa (Org.). Processo e Constituição: Estudos em homenagem ao professor José Carlos Barbosa Moreira. São Paulo: RT, 2006, p. 779-792.

SAlles, Carlos A (Org). As Grandes Transformações do Processo Civil Brasileiro. Homenagem ao Prof. Kazuo Watanabe. São Paulo: Quartier Latin, 2009.

SANDER, Frank E. A. Varieties of Dispute Processing, In: LEVIN, A. Leo; WHEELER, Russel R. The Pound Conference: Perspectives on Justice in the future. St. Paul: West Publishing Co., 1979, pp. 65-87

1991.

Emerging ADR Issues in State and Federal Courts, American Bar Association,

SANDER, Frank E. A., ROZDEICZER, Lukasz. Matching cases and dispute resolution procedures: detailed analysis leading to a mediation centered approach. Harvard Negotiation Law Review, vol. 11, 2006, pp. 1-41.

SANDER, Frank E.A.; GOLDBERG, Stephen B. Fitting the Forum to the Fuss: A UserFriendly Guide to Selecting an ADR Procedure, Negot. Journal, vol. 10, 1994.

SANTOS, Boaventura de Souza. O dircurso e o poder, Porto Alegre: Fabris, 1988.

SARAT, Austin; FELSTINER, William L. F. Divorce Lawyers and their clients: power and meaning in the legal process. NY: Oxford University Press, 1995. 
SIEMER, Deanne. Perspective of Advocates and Clients on Court-Sponsored ADR. In: SANDER, Frank (Org.). Emerging ADR Issues in State and Federal Courts, American Bar Association, 1991.

SILVA, Paulo Eduardo Alves da. Gerenciamento de processos judiciais. São Paulo: Saraiva, 2010.

SIX, Jean François. Dinâmica da Mediação. Tradução Aguida Arruda Barbosa, Eliana Nazareth e Giselle Groeninga. Belo Horizonte: Del Rey, 2001.

SUARES, Marinés. Mediación: conducción de disputas, comumicación y técnicas. Buenos Aires, Paidós, 2008.

SURGIK, Aloísio. A origem da Conciliação. Tese (Doutorado em Direito). Faculdade de Direito da USP, São Paulo, 1984.

TRUBEK, David M. The handmaiden's revenge: on reading and using the newer sociology of civil procedure, Law and Contemporary Problems, vol. 51, 1988.

. The construction and deconstruction of a Disputes-focused approach: an afterword. Law and Society Review, vol. 15, n. 3-4, 1980-1981, pp. 727-747.

VASCONCELLOS, J. M. P. de. Actos dos juizes de paz. Rio de Janeiro: Laemmert, 1862.

VELIKONJA, Urska. Making peace and making money: economic analysis of the market for mediators in private practice. Albany Law Review, vol. 72, 2009, pp. 257-291.

VEZULlA, Juan Carlos. Mediação: Teoria e Prática; Guia para Utilizadores e Profissionais. Lisboa: Agora Publicações Ltda, 2001.

WARAT, Luis Alberto. O ofício do mediador, v. 1. Florianópolis: Habitus, 2001.

WATANABE, Kazuo. Cultura da sentença e cultura da pacificação. In: YARSHELL, ZANOIDE (Coord). Estudos em homenagem à professora Ada Pellegrini Grinover. São Paulo: DPJ, 2005. pp. 684-690.

Acesso à Justiça e Sociedade Moderna. In: GRINOVER, Ada Pellegrini; DINAMARCO, Candido Rangel; WATANABE, Kazuo (Org.). Participação e Processo. São Paulo, Revista dos Tribunais, 1988, pp. 128-135.

. Modalidades de Mediação. Série Cadernos do CEJ, n. 22, Brasília: Conselho da Justiça Federal, 2001, pp. 45-46.

WATANABE, Kazuo (Org). Juizado especial de pequenas causas: Lei 7.244, de 7 de novembro de 1984. São Paulo: Revista dos Tribunais, 1985. 
WELSH, Nancy A; MCADOO, Bobbi; WISSLER, Roselle L. Institutionalization: What do Empirical Studies Tell Us about Court Mediation? Disp. Resol. Mag., vol. 9, 2003.

WELSH, Nancy A; MCADOO, Bobbi. Look before you leap and keep on looking: lessons from the institutionalization of Court-connected mediation. Nevada Law Journal, vol. 5, 2004-2005, pp. 399-432.

WELSH, Nancy A. Making deals in Court-Connected Mediation: What's Justice got to do with? Wash. U.L.Q, vol. 79, 2001, pp. 787-861.

.The Thinning vision of self-determination in Court-connected Mediation: The Inevitable price of institutionalization? Harvard Negotiation Law Review, vol. 6, 2001, pp. $1-96$.

The place of Court-connected mediation in a Democratic Justice System. Cardozo Journal of Conflict Resolution, vol. 5, 2004, pp. 117-144.

. Disputants' decision control in Court-Connected mediation: a hollow promise without procedural justice. Journal of Dispute Resolution, vol. 179, 2002, pp. 179-192.

Stepping back through the looking glass: real conversation with real disputants about institutionalized mediation and its value. Ohio State Journal on Dispute Resolution, vo. 19,2004 , pp. 573-673.

WINSLADE, John. MONK, Gerald. Narrative Mediation: a New Approach to Conflict Resolution. San Francisco: Jossey Bass Publishers, 2000.

ZAPPAROLLI, Célia Regina. Políticas Públicas de Justiça e a Mediação de Conflitos intrafamiliares em contextos de crimes processados pelas leis 9099/1995 e 11.340/2006. In: SALlES, Carlos A (Org). As Grandes Transformações do Processo Civil Brasileiro. Homenagem ao Prof. Kazuo Watanabe. São Paulo: Quartier Latin, 2009, pp. 536-568. 
9 ANEXOS

\section{ANEXO A. Questionário de entrevista aplicado aos Diretores dos Programas de Mediação em Ohio, Flórida, Maine e Connecticut}

Empirical research: the questionnaire (survey)

Name of the Program:

Local:

Date:

Interviewee:

1. Characteristics of the Program

a) When was the program implemented?

b) What kind of conflicts (family, juvenile, domestic relations, housing, traffic, small claim courts, mortgage foreclosure, labor, civil - tort, personal injury, appellate cases) can be referring to mediation (eligibility)?

c) Is the program regulated by some rules? What kind of rules (state or federal regulation)? Does the program follow the Uniform Mediation Act or another uniform standards?

d) Is the program related to a central office of Dispute Resolution? (centralized or decentralized)

e) Is the mediation voluntary or mandatory? Are the results of the mediation binding or nonbinding for the parties?

f) Do the parties need to pay fees? What are the likely costs?

g) How are the Court mediation programs supported (public or private resources)? Does the program have some partnership with the law school?

h) What kind of relationship exists between the program and the court system?

2. Screening process

a) How does the mediation begin?

- with a referral to mediation by the judge?

- with a mediation request by the parties or attorneys? 
b) Is there a request form available by the Court? Does the request need to be done by agreement of the parties? With the assistance of a lawyer?

c) Does the screening happen before or after the referral/request? Who does the selection of the cases that are opted into programs (the mediator, the judge, a clerk)?

d) Does the program admit pre-suit mediation? Or just admit mediation process after the lawsuit is filed?

e) How is the case evaluation process (parameters)? Are there rules to guide the screening process?

f) When can the referral or request be made? Does the mediation request stay or suspend the lawsuit filed by the same parties?

g) Before the mediation begins, can one of the parties give up and opt out?

h) Can the cases be readdressed to another technique to solve the conflict? When? Are there another court-sponsored ADR programs available (arbitration, early neutral evaluation, for example)?

i) Can the referral be made to some ADR program outside the Court?

j) Who has a more pro-active role during the screening or triage phase: the mediator, parties, counsels, judge, or manager? List in the decreasing order.

3. Dynamics of the mediation and proceeding

a) Approximately how long do the parties need to wait for the mediation 1st session? And for the end of the mediation process?

b) Can some pre-mediation meeting occur?

c) What is the likely number and length of mediation sessions?

d) Does the program admit mediations by phone or email?

e) Are there deadlines and time limit to the proceeding? Does the mediator adopt some schedule?

f) How is the mediation opened? How do the parties present the issues to mediators? Is the presentation made orally or in writing, by the parties themselves or by the attorneys speaking for them?

g) Are there some rules or statutes that the parties need to follow? If yes, are they rigid or flexible (can be changed or adopted in part)? 
h) Can the mediator hold individual meetings (caucus) with each party during the mediation?

i) How is the notice of the parties? Is the counsel also notified about the date of sessions and the agreement of the parties?

j) Is the mediation session confidential? Does some exception to the privilege is admitted by the program, with a disclosure of mediation communications in the legal proceeding?

4. The Roles

- Role of Manager

a) Does the program have a manager? How many?

b) What are the managers' main activities and responsibilities?

c) What is the managers' professional formation? Does he/she often have a law degree? Does he/she often have some practice in mediation?

- Role of the Mediator

a) Is he/she often an expert about the subject? Does he/she often have a law degree? Are the mediators often employees of the Courts? Retired judges?

b) Does the mediator need to do specific training? Is there some kind of certification?

c) How is the choice of the mediator? Does the Court offer some list of mediators for the parties?

d) Is it possible to change the mediator?

e) Can the parties ask the mediator to "switch hats" and serve as arbitrator?

f) What is the likely gender and age of the mediators?

g) What are the powers of the mediators (discretion)? Can he/she apply some sanctions (contempt of power)?

h) Does the mediator can report back some information, recommendation or impressions about the case to the Court?

i) Does the program follow specific rules about mediation ethics and accountability?

- Role of the Judge

a) Does the judge refer the cases to mediation? When? 
b) When another party makes the referral, does the judge need to approval it?

c) How are the judge and the court involvement during the mediation?

d) If the mediation doesn't occur at the beginning of the lawsuit, is it possible that during the proceeding the judge refers the case to mediation? When?

- Role of the Attorneys

a) Do both parties need to be assisted by attorneys? Or the parties can be self-represented?

b) What happens if one of the attorneys doesn't attend the mediation session?

c) Can the attorney of one party talk with the opposite party directly? Or just through the other attorney?

d) Can the attorney participate in the caucus?

e) Can just the attorneys attend the mediation session, without the parties?

- Role of the parties

a) Does the Court program gather information about: A) if it's the first time that the parties submitted the conflict to the court-connected program? B) if it's the first time that they use ADR even outside the Courts? C) Who suggested the mediation for the parties (if it's voluntary)?

b) What happens if the parties' representatives don't have sufficient settlement authority or don't appear at the first session? Does the mediator or the parties can request a judicial order to bring the right parties to the table?

c) Can the parties bring to the mediation session support people (friends, parents, ...)?

d) Does the Court program have some control about the repeat players?

e) Is it common in the mediation program a multi-party dispute?

f) Does the program admit class action in mediation?

g) Does the Court program apply some survey after the mediation process about the parties' expectations and satisfaction with the mediation's outcomes?

h) Does the Court program give a special treatment to the parties in case of imbalance of power between them?

5. The deal/agreement 
a) Is the parties' agreement subject to judicial review and approval?

b) Does the parties have a right to appeal? Can the case be submitted to mediation again?

6. The place and facilities

a) Where the mediation session is held? In the courthouse? Outside?

b) How is the place? How is the disposition of the seats and the table? Can the disposition of the seats change during the mediation?

7. Another observations

Are there some data or statistic available about the cases submitted to mediation? And about the cases mediated more than once, or the cases that the parties bring to the Court after the mediation (for enforcement of the agreement, or judgment of a part not decided by the deal)?

ANEXO B. Questionário de entrevista aplicado aos Coordenadores dos Programas de Mediação e Conciliação em São Paulo, Distrito Federal e Rio de Janeiro

Nome do entrevistado:

Setor visitado:

Local:

Data:

3. Há alguma regulamentação acerca do setor? Qual é a estrutura do setor (juiz

PARTE I - O SETOR DE CONCILIAÇÃO/MEDIAÇÃO

1.1. O setor de conciliação / mediação é: i. pré-processual

ii. processual

a) $1^{\mathrm{a}}$ instância

b) $2^{\mathrm{a}}$ instância

1.2. A mediação é:

i. voluntária

ii. obrigatória

2. Quando foi criado o setor? coordenador, cartório, vara) e como é financiado? Qual é a sua relação com o Tribunal? Há alguma parceria com Escola de Direito ou outra entidade?

4. Quais são os casos/conflitos que podem ser remetidos ao setor? Quais chegam mais frequentemente?

a) relações de família

b) vizinhança

c) ações de cobrança

d) relações de consumo

e) matéria penal

e) outros 
4.1. Há algum conflito que não possa ser remetido à conciliação?

5. Há limite de valor da causa submetido ao setor de conciliação/mediação?

a) não

b) sim. Qual?

6. Há um perfil de litigantes mais frequentes?

7. As partes pagam alguma taxa ou custas para utilizarem o setor de conciliação/mediação?

8. Quanto tempo demora em média para se agendar uma sessão de conciliação (pauta)? Quantas sessões de conciliação ocorrem por dia (estimativa) no setor? Qual é o tempo médio que dura a sessão?

\section{PARTe II - A Triagem dos Conflitos}

1. Sendo o setor de conciliação/mediação processual:

a) Como são feitos os encaminhamentos dos casos ao setor?

b) Quem faz este encaminhamento: o juiz, as partes, os advogados?

c) Em que momento do procedimento os casos são normalmente encaminhados?

d) Há critérios para escolha dos casos que são encaminhados ao setor (triagem)?

2. Sendo o setor de conciliação/mediação pré-processual, há algum tipo de triagem dos casos que vão para conciliação? Quem pode requerer a conciliação/mediação?

3. Existe algum formulário ou ficha a preencher pela parte que procura a conciliação/mediação?
4. Antes da conciliação/mediação, pode uma das partes desistir da sessão? Há muita ausência das partes nas sessões?

5. Durante o encaminhamento dos casos à mediação/conciliação, podem ser indicadas às partes outras formas (privadas) de solução de conflitos?

6. $\mathrm{O}(\mathrm{a}) \mathrm{Sr}(\mathrm{a})$ vê $\mathrm{o}$ setor de conciliação/mediação como um filtro dos casos que chegam ao Juiz?

\section{PARTe III - PAPÉIS dos ATORES ENVOLVIDOS}

\section{O Coordenador do Setor de Conciliação / Mediação e o Juiz}

i. Há um coordenador/diretor do setor? É funcionário do Tribunal? Quais são as suas principais atribuições e responsabilidades?

ii. Qual é a sua formação? É advogado(a)? Atua ou já teve alguma prática como mediador?

iii. Há algum juiz envolvido diretamente com o setor (juiz coordenador)? Em caso positivo, quais são as suas principais atribuições?

iv. O juiz da Vara (não coordenador) tem algum controle sobre os casos que são remetidos à conciliação / mediação?

v. Há algum envolvimento do juiz durante a sessão de mediação / conciliação?

\section{As partes}

i. Ambas as partes precisam estar presentes? Há alguma sanção se uma delas estiver ausente? 
ii. O que acontece se os representantes das partes não tem autoridade suficiente para fechar um acordo?

iii.. As partes precisam estar assistidas de advogados? O que acontece se apenas o advogado de uma das partes está presente?

iv. Há algum controle sobre litigantes repetitivos?

v. No caso de desnível de poder entre as partes, há algum cuidado especial na mediação?

vi. As partes podem trazer acompanhantes para a sessão de mediação / conciliação?

viii. É comum a mediação envolver várias partes? E mediação em ações coletivas?

viii. O setor tem informações quando é a primeira vez que as partes submetem o conflito à conciliação / mediação?

\section{Os advogados}

i. Os advogados de ambas as partes precisam estar presentes? O que acontece se apenas um dos advogados está presente?

ii. Apenas os advogados podem estar presentes (sem partes)?

iii. Estando presentes os advogados, eles assumem protagonismo na sessão ou as partes também tem voz?

iv. Como se dá a relação entre as partes e os advogados?

\section{O conciliador / mediador}

i. Qual é a formação do conciliador? (advogado, juiz, serventuário da justiça, desembargador aposentado, assistente social, estagiário de direito, outros) ii. O conciliador pode ser um especialista na matéria do conflito?

iii. O conciliador precisa fazer curso preparatório ou capacitação para conciliação /mediação? Quantas horas? Atua como voluntário?

iv. Qual é a faixa etária média do conciliador (menos de 30, entre 30 e 40 ou mais de 40)? É normalmente homem ou mulher?

v. O conciliador normalmente atua com conciliação ou mediação fora do Tribunal? Exerce atividade remunerada?

vi. Como se dá a escolha dos conciliadores/mediadores para o caso? Há alguma lista? Ele pode ser mudado?

vii. O mediador pode informar algo da sessão ao Juiz? Há alguma exceção à confidencialidade das sessões? Mantém registro das sessões? Há envolvimento do juiz durante as sessões?

viii. Há regras sobre ética e responsabilidade dos mediadores (seguese o Código de Ética do Conima)?

ix. Qual é o perfil adotado via de regra pelo conciliador? Facilitador, avaliador, passivo, pró-ativo?

\section{PARTE IV - DinâMiCa da CONCILIAÇão / MEDIAÇÃO E}

\section{O procedimento}

i. A conciliação é precedida por algum encontro/atendimento das partes? Como é o agendamento e como as partes são notificadas sobre a sessão? 
ii. Os prazos do processo judicial são suspensos enquanto se aguarda a mediação? Caso positivo, por quanto tempo?

iii. Há regras que regulem este procedimento de conciliação?

iv. O argumento sobre a morosidade do judiciário aparece durante $\mathrm{o}$ procedimento? Caso positivo, quem normalmente levanta este argumento? (as partes, o conciliador, os advogados?)

v. Durante a mediação/conciliação, há normalmente sessões individuais com as partes (caucus)?

\section{Os resultados}

i. Havendo acordo, o mesmo é reduzido a termo e homologado pelo juiz? Há algum modelo para o acordo?

ii. As partes podem submeter o mesmo caso à nova mediação?

iii. Há pesquisa de opinião após a sessão de conciliação/mediação sobre a satisfação das partes com o procedimento e resultado?

iv. Onde ocorrem as sessões de mediação? No Tribunal? Como é o local?

v. Há dados estatísticos sobre os casos submetidos à mediação? Sobre o cumprimento dos acordos?

\section{Outras observações gerais:}




\title{
ANEXO C. Resolução no 125 do CNJ, de 29/11/2010 e Código de Ética de Conciliadores e Mediadores Judiciais
}

\author{
RESOLUÇÃO Nº 125, DE 29 DE NOVEMBRO DE 2010.
}

\begin{abstract}
Dispõe sobre a Política Judiciária Nacional de tratamento adequado dos conflitos de interesses no âmbito do Poder Judiciário e dá outras providências.
\end{abstract}

O PRESIDENTE DO CONSELHO NACIONAL DE JUSTIÇA, no uso de suas atribuições constitucionais e regimentais,

CONSIDERANDO que compete ao Conselho Nacional de Justiça o controle da atuação administrativa e financeira do Poder Judiciário, bem como zelar pela observância do art. 37 da Constituição da República;

CONSIDERANDO que a eficiência operacional, o acesso ao sistema de Justiça e a responsabilidade social são objetivos estratégicos do Poder Judiciário, nos termos da Resolução/CNJ nº 70, de 18 de março de 2009;

CONSIDERANDO que o direito de acesso à Justiça, previsto no art. $5^{\circ}, \mathrm{XXXV}$, da Constituição Federal além da vertente formal perante os órgãos judiciários, implica acesso à ordem jurídica justa;

CONSIDERANDO que, por isso, cabe ao Judiciário estabelecer política pública de tratamento adequado dos problemas jurídicos e dos conflitos de interesses, que ocorrem em larga e crescente escala na sociedade, de forma a organizar, em âmbito nacional, não somente os serviços prestados nos processos judiciais, como também os que possam sê-lo mediante outros mecanismos de solução de conflitos, em especial dos consensuais, como a mediação e a conciliação;

CONSIDERANDO a necessidade de se consolidar uma política pública permanente de incentivo e aperfeiçoamento dos mecanismos consensuais de solução de litígios;

CONSIDERANDO que a conciliação e a mediação são instrumentos efetivos de pacificação social, solução e prevenção de litígios, e que a sua apropriada disciplina em programas já implementados nos país tem reduzido a excessiva judicialização dos conflitos de interesses, a quantidade de recursos e de execução de sentenças;

CONSIDERANDO ser imprescindível estimular, apoiar e difundir a sistematização e o aprimoramento das práticas já adotadas pelos tribunais;

CONSIDERANDO a relevância e a necessidade de organizar e uniformizar os serviços de conciliação, mediação e outros métodos consensuais de solução de conflitos, para 
lhes evitar disparidades de orientação e práticas, bem como para assegurar a boa execução da política pública, respeitadas as especificidades de cada segmento da Justiça;

CONSIDERANDO que a organização dos serviços de conciliação, mediação e outros métodos consensuais de solução de conflitos deve servir de princípio e base para a criação de Juízos de resolução alternativa de conflitos, verdadeiros órgãos judiciais especializados na matéria;

CONSIDERANDO o deliberado pelo Plenário do Conselho Nacional de Justiça na sua $117^{\text {a }}$ Sessão Ordinária, realizada em de 23 de 2010, nos autos do procedimento do Ato 0006059-82.2010.2.00.0000;

RESOLVE:

\section{Capítulo I}

Da Política Pública de tratamento adequado dos conflitos de interesses

Art. $1^{\circ}$. Fica instituída a Política Judiciária Nacional de tratamento dos conflitos de interesses, tendente a assegurar a todos o direito à solução dos conflitos por meios adequados à sua natureza e peculiaridade.

Parágrafo único. Aos órgãos judiciários incumbe, além da solução adjudicada mediante sentença, oferecer outros mecanismos de soluções de controvérsias, em especial os chamados meios consensuais, como a mediação e a conciliação, bem assim prestar atendimento e orientação ao cidadão.

Art. $2^{\circ}$. Na implementação da Política Judiciária Nacional, com vista à boa qualidade dos serviços e à disseminação da cultura de pacificação social, serão observados: centralização das estruturas judiciárias, adequada formação e treinamento de servidores, conciliadores e mediadores, bem como acompanhamento estatístico específico.

Art. $3^{\circ}$. O CNJ auxiliará os tribunais na organização dos serviços mencionados no art. $1^{\circ}$, podendo ser firmadas parcerias com entidades públicas e privadas.

\section{Capítulo II \\ Das Atribuições do Conselho Nacional de Justiça}

Art. $4^{\circ}$. Compete ao Conselho Nacional de Justiça organizar programa com o objetivo de promover ações de incentivo à autocomposição de litígios e à pacificação social por meio da conciliação e da mediação.

Art. $5^{\circ}$. O programa será implementado com a participação de rede constituída por todos os órgãos do Poder Judiciário e por entidades públicas e privadas parceiras, inclusive universidades e instituições de ensino.

Art. $6^{\circ}$ Para desenvolvimento dessa rede, caberá ao CNJ: 
I - estabelecer diretrizes para implementação da política pública de tratamento adequado de conflitos a serem observadas pelos Tribunais;

II - desenvolver conteúdo programático mínimo e ações voltadas à capacitação em métodos consensuais de solução de conflitos, para servidores, mediadores, conciliadores e demais facilitadores da solução consensual de controvérsias;

III - providenciar que as atividades relacionadas à conciliação, mediação e outros métodos consensuais de solução de conflitos sejam consideradas nas promoções e remoções de magistrados pelo critério do merecimento;

IV - regulamentar, em código de ética, a atuação dos conciliadores, mediadores e demais facilitadores da solução consensual de controvérsias;

V - buscar a cooperação dos órgãos públicos competentes e das instituições públicas e privadas da área de ensino, para a criação de disciplinas que propiciem o surgimento da cultura da solução pacífica dos conflitos, de modo a assegurar que, nas Escolas da Magistratura, haja módulo voltado aos métodos consensuais de solução de conflitos, no curso de iniciação funcional e no curso de aperfeiçoamento;

VI - estabelecer interlocução com a Ordem dos Advogados do Brasil, Defensorias Públicas, Procuradorias e Ministério Público, estimulando sua participação nos Centros Judiciários de Solução de Conflitos e Cidadania e valorizando a atuação na prevenção dos litígios;

VII - realizar gestão junto às empresas e às agências reguladoras de serviços públicos, a fim de implementar práticas autocompositivas e desenvolver acompanhamento estatístico, com a instituição de banco de dados para visualização de resultados, conferindo selo de qualidade;

VIII - atuar junto aos entes públicos de modo a estimular a conciliação nas demandas que envolvam matérias sedimentadas pela jurisprudência.

\section{Capítulo III \\ Das Atribuições dos Tribunais}

\section{Seção I \\ Dos Núcleos Permanentes de Métodos Consensuais de Solução de Conflitos}

Art. $7^{\circ}$. Os Tribunais deverão criar, no prazo de 30 dias, Núcleos Permanentes de Métodos Consensuais de Solução de Conflitos, compostos por magistrados da ativa ou aposentados e servidores, preferencialmente atuantes na área, com as seguintes atribuições, entre outras:

I - desenvolver a Política Judiciária de tratamento adequado dos conflitos de interesses, estabelecida nesta Resolução;

II - planejar, implementar, manter e aperfeiçoar as ações voltadas ao cumprimento da política e suas metas; 
III - atuar na interlocução com outros Tribunais e com os órgãos integrantes da rede mencionada nos arts. $5^{\circ}$ e $6^{\circ}$;

IV - instalar Centros Judiciários de Solução de Conflitos e Cidadania que concentrarão a realização das sessões de conciliação e mediação que estejam a cargo de conciliadores e mediadores, dos órgãos por eles abrangidos;

$\mathrm{V}$ - promover capacitação, treinamento e atualização permanente de magistrados, servidores, conciliadores e mediadores nos métodos consensuais de solução de conflitos;

VI - na hipótese de conciliadores e mediadores que atuem em seus serviços, criar e manter cadastro, de forma a regulamentar o processo de inscrição e de desligamento;

VII - regulamentar, se for o caso, a remuneração de conciliadores e mediadores, nos termos da legislação específica;

VIII - incentivar a realização de cursos e seminários sobre mediação e conciliação e outros métodos consensuais de solução de conflitos;

IX - firmar, quando necessário, convênios e parcerias com entes públicos e privados para atender aos fins desta Resolução.

Parágrafo único. A criação dos Núcleos e sua composição deverão ser informadas ao Conselho Nacional de Justiça.

\section{Seção II \\ Dos Centros Judiciários de Solução de Conflitos e Cidadania}

Art. $8^{\circ}$. Para atender aos Juízos, Juizados ou Varas com competência nas áreas cível, fazendária, previdenciária, de família ou dos Juizados Especiais Cíveis e Fazendários, os Tribunais deverão criar os Centros Judiciários de Solução de Conflitos e Cidadania ("Centros"), unidades do Poder Judiciário, preferencialmente, responsáveis pela realização das sessões e audiências de conciliação e mediação que estejam a cargo de conciliadores e mediadores, bem como pelo atendimento e orientação ao cidadão.

$\S 1^{\circ}$. Todas as sessões de conciliação e mediação pré- processuais deverão ser realizadas nos Centros, podendo, excepcionalmente, as sessões de conciliação e mediação processuais ser realizadas nos próprios Juízos, Juizados ou Varas designadas, desde que o sejam por conciliadores e mediadores cadastrados junto ao Tribunal (inciso VI do art. $7^{\circ}$ ) e supervisionados pelo Juiz Coordenador do Centro (art. $9^{\circ}$ ).

$\S 2^{\circ}$. Os Centros deverão ser instalados nos locais onde exista mais de um Juízo, Juizado ou Vara com pelo menos uma das competências referidas no caput.

$\S 3^{\circ}$. Nas Comarcas das Capitais dos Estados e nas sedes das Seções e Regiões Judiciárias, bem como nas Comarcas do interior, Subseções e Regiões Judiciárias de maior movimento forense, o prazo para a instalação dos Centros será de 4 (quatro) meses a contar do início de vigência desta Resolução.

$\S 4^{\circ}$. Nas demais Comarcas, Subseções e Regiões Judiciárias, o prazo para a instalação dos Centros será de 12 (doze) meses a contar do início de vigência deste ato. 
$\S 5^{\circ}$. Os Tribunais poderão, excepcionalmente, estender os serviços do Centro a unidades ou órgãos situados em outros prédios, desde que próximos daqueles referidos no $\S$ $2^{\circ}$, podendo, ainda, instalar Centros nos chamados Foros Regionais, nos quais funcionem dois ou mais Juízos, Juizados ou Varas, observada a organização judiciária local.

Art. $9^{\circ}$. Os Centros contarão com um juiz coordenador e, se necessário, com um adjunto, aos quais caberá a sua administração, bem como a supervisão do serviço de conciliadores e mediadores. Os magistrados serão designados pelo Presidente de cada Tribunal dentre aqueles que realizaram treinamento segundo o modelo estabelecido pelo CNJ, conforme Anexo I desta Resolução.

$\S 1^{\circ}$. Caso o Centro atenda a grande número de Juízos, Juizados ou Varas, o respectivo juiz coordenador poderá ficar designado exclusivamente para sua administração.

$\S 2^{\circ}$. Os Tribunais deverão assegurar que nos Centros atuem servidores com dedicação exclusiva, todos capacitados em métodos consensuais de solução de conflitos e, pelo menos, um deles capacitado também para a triagem e encaminhamento adequado de casos.

$\S 3^{\circ}$. O treinamento dos servidores referidos no parágrafo anterior deverá observar as diretrizes estabelecidas pelo CNJ conforme Anexo I desta Resolução.

Art. 10. Cada unidade dos Centros Judiciários de Solução de Conflitos e Cidadania deverá obrigatoriamente abranger setor de solução de conflitos pré-processual, setor de solução de conflitos processual e setor de cidadania, facultativa a adoção pelos Tribunais do procedimento sugerido no Anexo II desta Resolução.

Art. 11. Nos Centros poderão atuar membros do Ministério Público, defensores públicos, procuradores e/ou advogados.

\section{Seção III \\ Dos Conciliadores e Mediadores}

Art. 12. Nos Centros, bem como em todos os demais órgãos judiciários nos quais se realizem sessões de conciliação e mediação, somente serão admitidos mediadores e conciliadores capacitados na forma deste ato (Anexo I), cabendo aos Tribunais, antes de sua instalação, realizar o curso de capacitação, podendo fazê-lo por meio de parcerias.

$\S 1^{\circ}$. Os Tribunais que já realizaram a capacitação referida no caput poderão dispensar os atuais mediadores e conciliadores da exigência do certificado de conclusão do curso de capacitação, mas deverão disponibilizar cursos de treinamento e aperfeiçoamento, na forma do Anexo I, como condição prévia de atuação nos Centros.

$\S 2^{\circ}$. Todos os conciliadores, mediadores e outros especialistas em métodos consensuais de solução de conflitos deverão submeter-se a reciclagem permanente e à avaliação do usuário.

$\S 3^{\circ}$. Os cursos de capacitação, treinamento e aperfeiçoamento de mediadores e conciliadores deverão observar o conteúdo programático e carga horária mínimos estabelecidos pelo CNJ (Anexo 1) e deverão ser seguidos necessariamente de estágio supervisionado. 
$\S 4^{\circ}$. Os mediadores, conciliadores e demais facilitadores do entendimento entre as partes ficarão sujeitos ao código de ética estabelecido pelo Conselho (Anexo III).

\section{Seção IV \\ Dos Dados Estatísticos}

Art. 13. Os Tribunais deverão criar e manter banco de dados sobre as atividades de cada Centro, com as informações constantes do Anexo IV.

Art. 14. Caberá ao CNJ compilar informações sobre os serviços públicos de solução consensual das controvérsias existentes no país e sobre o desempenho de cada um deles, por meio do DPJ, mantendo permanentemente atualizado o banco de dados.

\section{Capítulo IV}

\section{Do Portal da Conciliação}

Art. 15. Fica criado o Portal da Conciliação, a ser disponibilizado no sítio do CNJ na rede mundial de computadores, com as seguintes funcionalidades, entre outras:

I - publicação das diretrizes da capacitação de conciliadores e mediadores e de seu código de ética;

II - relatório gerencial do programa, por Tribunal, detalhado por unidade judicial e por Centro, com base nas informações referidas no Anexo IV; estudos;

III - compartilhamento de boas práticas, projetos, ações, artigos, pesquisas e outros

IV - fórum permanente de discussão, facultada a participação da sociedade civil;

V - divulgação de notícias relacionadas ao tema;

VI - relatórios de atividades da "Semana da Conciliação".

Parágrafo único. A implementação do Portal será gradativa, observadas as possibilidades técnicas, sob a responsabilidade do CNJ.

\section{Disposições Finais}

Art. 16. O disposto na presente Resolução não prejudica a continuidade de programas similares já em funcionamento, cabendo aos Tribunais, se necessário, adaptá-los aos termos deste ato.

Art. 17. Compete à Presidência do Conselho Nacional de Justiça, com o apoio da Comissão de Acesso ao Sistema de Justiça e Responsabilidade Social, coordenar as atividades da Política Judiciária Nacional de tratamento adequado dos conflitos de interesses, cabendolhe instituir, regulamentar e presidir o Comitê Gestor da Conciliação, que será responsável pela implementação e acompanhamento das medidas previstas neste ato. 
Art. 18. Os Anexos integram esta Resolução e possuem caráter vinculante, à exceção do Anexo II, que contém mera recomendação.

Art. 19. Esta Resolução entra em vigor na data de sua publicação.

\section{Ministro Cezar Peluso \\ Presidente}

\section{ANEXO \\ CÓDIGO DE ÉTICA DE CONCILIADORES E MEDIADORES JUDICIAIS \\ INTRODUÇÃO}

O CONSELHO NACIONAL DE JUSTIÇA, a fim de assegurar o desenvolvimento da Política Pública de tratamento adequado dos conflitos e a qualidade dos serviços de conciliação e mediação enquanto instrumentos efetivos de pacificação social e de prevenção de litígios, institui o Código de Ética, norteado por princípios que formam a consciência dos terceiros facilitadores, como profissionais, e representam imperativos de sua conduta.

\section{Dos princípios e garantias da conciliação e mediação judiciais}

Artigo $1^{\circ}$ - São princípios fundamentais que regem a atuação de conciliadores e mediadores judiciais: confidencialidade, competência, imparcialidade, neutralidade, independência e autonomia, respeito à ordem pública e às leis vigentes.

$\S 1^{\circ}$. Confidencialidade - Dever de manter sigilo sobre todas as informações obtidas na sessão, salvo autorização expressa das partes, violação à ordem pública ou às leis vigentes, não podendo ser testemunha do caso, nem atuar como advogado dos envolvidos, em qualquer hipótese;

$\S 2^{\circ}$. Competência - Dever de possuir qualificação que o habilite à atuação judicial, com capacitação na forma desta Resolução, observada a reciclagem periódica obrigatória para formação continuada;

$\S 3^{\circ}$. Imparcialidade - Dever de agir com ausência de favoritismo, preferência ou preconceito, assegurando que valores e conceitos pessoais não interfiram no resultado do trabalho, compreendendo a realidade dos envolvidos no conflito e jamais aceitando qualquer espécie de favor ou presente;

$\S 4^{\circ}$. Neutralidade - Dever de manter equidistância das partes, respeitando seus pontos de vista, com atribuição de igual valor a cada um deles;

$\S 5^{\circ}$. Independência e autonomia - Dever de atuar com liberdade, sem sofrer qualquer pressão interna ou externa, sendo permitido recusar, suspender ou interromper a sessão se ausentes as condições necessárias para seu bom desenvolvimento, tampouco havendo obrigação de redigir acordo ilegal ou inexequível;

$\S 6^{\circ}$. Respeito à ordem pública e às leis vigentes - Dever de velar para que eventual acordo entre os envolvidos não viole a ordem pública, nem contrarie as leis vigentes. 


\section{Das regras que regem o procedimento de conciliação/mediação}

Art. $2^{\circ}$. As regras que regem o procedimento da conciliação/mediação são normas de conduta a serem observadas pelos conciliadores/mediadores para seu bom desenvolvimento, permitindo que haja o engajamento dos envolvidos, com vistas à sua pacificação e ao comprometimento com eventual acordo obtido, sendo elas:

$\S 1^{\circ}$. Informação - Dever de esclarecer os envolvidos sobre o método de trabalho a ser empregado, apresentando-o de forma completa, clara e precisa, informando sobre os princípios deontológicos referidos no capítulo I, as regras de conduta e as etapas do processo.

$\S 2^{\circ}$. Autonomia da vontade - Dever de respeitar os diferentes pontos de vista dos envolvidos, assegurando-lhes que cheguem a uma decisão voluntária e não coercitiva, com liberdade para tomar as próprias decisões durante ou ao final do processo, podendo inclusive interrompê-lo a qualquer momento.

$\S 3^{\circ}$. Ausência de obrigação de resultado - Dever de não forçar um acordo e de não tomar decisões pelos envolvidos, podendo, quando muito, no caso da conciliação, criar opções, que podem ou não ser acolhidas por eles.

$\S 4^{\circ}$. Desvinculação da profissão de origem - Dever de esclarecer aos envolvidos que atua desvinculado de sua profissão de origem, informando que, caso seja necessária orientação ou aconselhamento afetos a qualquer área do conhecimento poderá ser convocado para a sessão o profissional respectivo, desde que com o consentimento de todos.

$\S 5^{\circ}$. Teste de realidade - Dever de assegurar que os envolvidos, ao chegarem a um acordo, compreendam perfeitamente suas disposições, que devem ser exequíveis, gerando o comprometimento com seu cumprimento.

\section{Das responsabilidades e sanções do conciliador/mediador}

Art. $3^{\circ}$. Apenas poderão exercer suas funções perante o Poder Judiciário conciliadores e mediadores devidamente capacitados e cadastrados pelos tribunais, aos quais competirá regulamentar o processo de inclusão e exclusão no respectivo cadastro.

Art. $4^{\circ}$. O conciliador/mediador deve exercer sua função com lisura, respeitando os princípios e regras deste Código, assinando, para tanto, no início do exercício, termo de compromisso e submetendo-se às orientações do juiz coordenador da unidade a que vinculado;

Art. $5^{\circ}$. Aplicam-se aos conciliadores/mediadores os mesmos motivos de impedimento e suspeição dos juízes, devendo, quando constatados, serem informados aos envolvidos, com a interrupção da sessão e sua substituição.

Art. $6^{\circ}$. No caso de impossibilidade temporária do exercício da função, o conciliador/mediador deverá informar com antecedência ao responsável para que seja providenciada sua substituição na condução das sessões. 
Art. $7^{\circ}$. O conciliador/mediador fica absolutamente impedido de prestar serviços profissionais, de qualquer natureza, pelo prazo de dois anos, aos envolvidos em processo de conciliação/mediação sob sua condução.

Art. $8^{\circ}$. O descumprimento dos princípios e regras estabelecidos neste Código, bem como a condenação definitiva em processo criminal, resultará na exclusão do conciliador/mediador do respectivo cadastro e no impedimento para atuar nesta função em qualquer outro órgão do Poder Judiciário nacional.

Parágrafo único - Qualquer pessoa que venha a ter conhecimento de conduta inadequada por parte do conciliador/mediador poderá representá-lo ao Juiz Coordenador a fim de que sejam adotadas as providências cabíveis. 